\title{
The inflammatory response and resting energy expenditure in lung cancer
}

\author{
Citation for published version (APA):
}

Staal-van den Brekel, A. J. (1996). The inflammatory response and resting energy expenditure in lung cancer. [Doctoral Thesis, Maastricht University]. Universiteit Maastricht. https://doi.org/10.26481/dis.19961206as

Document status and date:

Published: 01/01/1996

DOI:

10.26481/dis.19961206as

Document Version:

Publisher's PDF, also known as Version of record

\section{Please check the document version of this publication:}

- A submitted manuscript is the version of the article upon submission and before peer-review. There can be important differences between the submitted version and the official published version of record.

People interested in the research are advised to contact the author for the final version of the publication, or visit the DOI to the publisher's website.

- The final author version and the galley proof are versions of the publication after peer review.

- The final published version features the final layout of the paper including the volume, issue and page numbers.

Link to publication

\footnotetext{
General rights rights.

- You may freely distribute the URL identifying the publication in the public portal. please follow below link for the End User Agreement:

www.umlib.nl/taverne-license

Take down policy

If you believe that this document breaches copyright please contact us at:

repository@maastrichtuniversity.nl

providing details and we will investigate your claim.
}

Copyright and moral rights for the publications made accessible in the public portal are retained by the authors and/or other copyright owners and it is a condition of accessing publications that users recognise and abide by the legal requirements associated with these

- Users may download and print one copy of any publication from the public portal for the purpose of private study or research.

- You may not further distribute the material or use it for any profit-making activity or commercial gain

If the publication is distributed under the terms of Article $25 \mathrm{fa}$ of the Dutch Copyright Act, indicated by the "Taverne" license above, 


\section{The inflammatory response and resting energy expenditure in lung cancer}





\title{
The inflammatory response and resting energy expenditure in lung cancer
}

\author{
PROEFSCHRIFT
}

ter verkrijging van de graad van doctor aan de Universiteit Maastricht,

op gezag van de Rector Magnificus, Prof. mr. M.J. Cohen, volgens het besluit van het College van Dekanen.

in het openbaar te verdedigen

op vrijdag 6 december 1996 om 16.00 uur

door

Agnes Josefien Staal - van den Brekel

geboren op 18 augustus 1965 te Vught 


\section{Promotor}

Prof.dr E.F.M. Wouters

Co-promotor

Dr W.A. Buurman

Beoordelingscommisie

Prof.dr M.F. von Meyenfeldt (voorzitter)

Prof.dr F.C. Fearon (University of Edinburgh, U.K.)

Prof.dr H.F.P. Hillen

Prof.dr W.H.M. Saris

CIP-DATA KONINKLIJKE BIBLIOTHEEK, DEN HAAG

Staal - van den Brekel, Agnes Josefien

The inflammatory response and resting energy expenditure in lung, cancer/ Agnes Josefien Staal - van den Brekel, Maastricht.

Thesis Maastricht.-With ref.-With summary in Dutch

ISBN 90-9010030-X

Subject headings: energy metabolism / inflammation / lung cancer

Layout: Jeske Staal - van den Brekel

Production: Ponsen \& Looyen BV

Het onderzoek gepresenteerd in dit proefschrift werd mogelijk gemaakt door subsidie van de Nederlandse Organisatie voor Wetenschappelijk onderzoek (N.W.O., projectnummer MW 900-562-110), Den Haag 
Voor Hans Philip en Diederik 
De verschijning van dit proefschrift werd mede mogelijk gemaakt door financiële bijdragen van Astra Pharmaceutica, Bristol-Myers Squibb, Glaxo Wellcome, Pfizer. en Pharmacia\& Upjohn 


\section{Contents}

Chapter 1 Introduction 9

Chapter 2 Analysis of the energy balance in lung cancer patients 31

Chapter 3 Hypermetabolism is more pronounced in small cell lung carcinoma compared to non-small cell lung carcinoma and healthy controls

Chapter 4 Increased resting energy expenditure and weight loss are related to a systemic inflammatory response in lung cancer patients

Chapter 5 The expression of cytokines and TNF-receptors in non-small cell lung carcinoma

Chapter 6 Expression of E-selectin, Intercellular Adhesion Molecule (ICAM)1 and Vascular Cell Adhesion Molecule (VCAM)-1 in non-smal! cell lung carcinoma

Chapter 7 The enhanced inflammatory response in non-smali cell lung carcinoma is not reflected in the alveolar compartment

Chapter 8 Energy Balance in non-small cell lung cancer patients before and after surgical resection of the tumor

Chapter 9 The effects of treatment with chemotherapy on energy metabolism and inflammatory mediators in small cell lung carcinoma

Chapter 10 General discussion

Summary

Samenvatting

Dankwoord

Curriculum vitae

List of publications 



\section{Chapter 1}

\section{INTRODUCTION}

\subsection{Weight loss in cancer}

Weight loss is a frequently occurring problem in cancer patients and is an early sign of disease. Nearly every patient suffering from cancer will develop weight loss during the course of disease (1-6). Data from the Eastern Cooperative Oncology Group demonstrated that $50 \%$ of oncology patients will even have some weight loss at the time of initial diagnosis and $16 \%$ will have lost more than $10 \%$ of their preillness weight at that time (1). Patients with breast cancer demonstrated the lowest frequency of weight loss (14\% losing more than $5 \%$ of their initial weight during 6 months before diagnosis) whereas patients with lung and gastric cancer lost the same amount of weight in $35 \%$ and more than $60 \%$ of the cases respectively (1). The presence of weight loss has important consequences for therapeutic outcome. In general, stable weight cancer patients have a better prognosis and a better response to treatment than weight losing patients (1-6). As part of the so-called B-symptom complex in malignant lymphomas, weight loss can even result in a stage-adapted therapy (7). Cancer patients who have lost a significant percentage of their body weight before surgical treatment are subject to a much greater risk of postoperative mortality and morbidity (8-10). Weight loss has also an important prognostic impact in lung cancer patients, especially in the non-small cell subtype group (reviewed in 11): loss of $5 \%$ of pre-illness weight in inoperable lung cancer patients reduced survival ratios significantly compared to weight stable lung cancer patients $(6,11$ 13).

In general, weight loss can be considered as a disturbance of the energy balance, resulting from a decreased energy intake, an increased energy expenditure or a combination of both of them. Weight loss forms a major characteristic of the clinical syndrome of cancer cachexia. The term cachexia is derived from the Greek words kakos hexos, meaning "bad condition". Cancer cachexia describes the syndrome that consists of weight loss and abnormalities in carbohydrate, protein and lipid metabolism. The metabolic changes include a reduction in body fat and muscle tissue, hypoglycemia, anorexia, anemia and asthenia, resulting in a state of net negative energy balance. Only surgical, radiotherapeutic or chemotherapeutic control of the tumor can completely reverse this syndrome of cachexia $(2,4,14)$.

For a long time the cancer-induced reduction of energy intake or anorexia was considered as the most important factor in the disturbance of the energy balance. Anorexia refers to alterations in food perception, including alterations in taste and. 


\section{Chapter I}

smell, that result in reduced food intake $(2,15)$. In that sence, anorexia may be caused by lack of appetite, premature satiety, reduced motor activity of feeding, pain, averse taste perception or withdrawal. However, the characteristics of anorexia are difficult to assess in practice and studies related to anorexia are difficult to compare by the use of different methodologies. In addition, most studies are performed in patients at a terminal phase of their disease. Only limited data are available about the energy intake of patients in the early phase of cancer development (16). Besides the presence of anorexia, reduced energy intake in cancer patients can be a consequence of numerous clinical factors like intestinal obstruction by the tumor, radiotherapy, chernotherapy-induced nausea and vomiting, oral ulceration, atrophy of the gastrointestinal tract and depression or anxiety $(2,17-19)$. Different mechanisms have been proposed in the tumor-host relationship to explain the reduced energy intake in cancer patients. Tumor produced factors like serotonin, produced by bronchial and gastrointestinal carcinoid tumors and bombesin, produced by small cell lung carcinomas, are reported to decrease energy intake $(3,20)$. Furthermore, changes in amino acid metabolism can influence the neuroregulatory processes of energy intake in the hypothalamus of the host. The essential amino acid tryptophan has been widely studied because it is the precursor amino acid for synthesis of the neurotransmitter serotonin in the brain. Serotonin has been associated with inhibitory control on food intake behavior and inhibition of serotonin synthesis seemed to postpone the onset of anorexia (21). However, blocking of serotonergic neurons, destroying serotonergic neurons and chemical stimulation of the paraventricular hypothalamus in combination with manipulations of the serotonin system, did not result in restoration of food intake in tumor bearing animals to normal levels (22).

During the last years the involvement of cytokines in experimental cancer cachexia has been a topic of extensive research. Cancer cachexia in these animal models is considered to be mediated by complex interactions of cytokines. Cytokines are polypeptide mediators produced by a variety of immune cells that are critical regulators of immune function. In addition, cytokines can also be produced by tumor cells themselves. Pro-inflammatory cytokines like Tumor Necrosis Factor (TNF)- $\alpha$, Interleukin (IL)-1, Il- 6 and Interferon (IFN)- $\gamma$ influence the energy balance as has been demonstrated in several animal studies (23-25). The direct administration of TNF $-\alpha$ in animals resulted in hypertriglyceridemia, hypoglycemia, anorexia and weight loss (25). Further influences of cytokines on the energy balance will be discussed later on.

Recently important information has become available on the regulation of food intake. Glucagon-like peptide (GLP)-1 was found to be an important inhibitor of feeding in the brains of rats (26). GLP-1 is proteolytically derived from the proglucagon molecule and expressed in both the pancreatic A-cells and the intestinal L cells (27). GLP-1 modulates the glucose-induced insulin secretion and could influence carbohydrate metabolism in that way. However, its role in man and 
especially its relation to cancer cachexia remains to be determined.

Besides quantitative assessment of total energy intake in cancer patients, qualitative changes in substrate utilization have to be considered in the development of weight loss. Experimental tumor-bearing animal studies have shown that energy-dependent metabolic cycles are disturbed even before the manifestations of weight loss. Changes in body composition occur due to changes in metabolism of fat, glucose and protein. Many studies have shown that the major proportion of weight loss in cancer is caused by depletion of fat (28-30). Triglyceride in adipocytes, which represents the major storage form of fat, is mobilized by hydrolysis to glycerol and free fatty acids that are released into plasma. Shaw et al. (31) demonstrated increased turnover rates of glycerol and free fatty acids in weight losing patients. Lipoprotein lipase activity, the enzyme responsible for the clearance of triglyceride molecules from the plasma, was found to be decreased in cancer patients. In addition, many studies indicated that fat is oxidized at an increased rate in cancer patients (32-35). Increased glucose synthesis, decreased glucose tolerance and turnover, insulin resistance, increased gluconeogenesis and increased Cori cycle activity are among the known carbohydrate abnormalities found in cancer patients (36-39). Disturbances in protein metabolism are reflected by increased rates of muscle protein breakdown, increased whole body protein turnover, and increased liver protein synthesis in combination with decreased rates of skeletal muscle protein synthesis resulting in net host protein wasting (40-43).

Recently insight in the regulation of metabolism of adipose tissue has increased by the discovery of the $o b$ gene product or leptin in adipose tissue of mice (44) and subsequent cloning of its homologues in men and rats $(45,46)$. Leptin has been demonstrated to regulate body weight homeostasis and energy balance by reducing food intake and increasing energy expenditure $(47,48)$. Changes in leptin levels are considered to explain at least in part the observed alterations in body composition in cancer patients. Injection of purified recombinant leptin dramatically reduced body weight of $o b / o b$ and wild-type mice through an effect on insulin levels (46). The putative involvement of leptin in energy expenditure needs to be further investigated.

Although many investigators have observed changes in energy intake both in tumor bearing animals and cancer patients, these data do not fully explain weight loss in cancer. Several studies have even shown a similar energy intake for weight losing patients compared to weight losing controls and weight stable cancer patients (49). Therefore also energy expenditure needs to be investigated in order to understand this complex problem of weight loss in cancer. 


\section{Chapter I}

\subsection{Energy Expenditure in cancer patients}

Total energy expenditure consists of resting energy expenditure (REE), diet-induced thermogenesis and physical activities. REE is the major determinant of total energy expenditure, amounting to about $70 \%$ in sedentary persons. REE comprises the sleeping metabolic rate and the energy cost of arousal, which can be defined as the minimum rate of energy expenditure in an awake, relaxed person, lying on a bed, after an overnight fast $(50,51)$. The introduction of equipment allowing measurement of REE at the bedside has stimulated interest to measure REE in different groups of patients. While REE normally decreases during starvation and weight loss in healthy individuals or patients (52), conflicting studies about REE are reported in malignant diseases. Reduced (53), normal (54-56) and increased REE (57-59) are demonstrated in cancer patients in comparison with control groups. Differences among these studies can be explained by the number of patients investigated, the heterogenity of cancer patients with unspecified stages of disease, the experimental methods used and the non-adjustment of REE for body composition. However, different tumor types seemed to influence REE differently. In general, an increased REE has been reported in lung cancer patients $(54,59,60)$. Hansell et al. (54) compared REE of 11 non-small cell lung carcinoma (NSCLC) with values of gastric and colorectal cancer patients and found a significantly higher REE in NSCLC patients when expressed in terms of body weight. However, when corrected for body composition, no significant differences in REE were detected between the groups. Russell et al. studied REE in small cell lung carcinoma (SCLC) patients: REE measured by indirect calorimetry was $31 \%$ higher than the predicted resting energy expenditure determined by the Harris Benedict (HB) formula (61). Former studies of our group performed by Fredrix et al. demonstrated that 18 out of 30 patients with newly detected NSCLC were hypermetabolic (60). In a sub group, REE was measured before and after surgical resection. NSCLC patients with no evidence of tumor recurrence had a significant decrease in REE to a normal level (62).

Although REE can be increased in some types of cancer patients, total energy expenditure should be taken into account in the assessment of energy balance in these patients. Until now only few studies on total energy expenditure have been performed in heterogeneous groups of cancer patients with contradicting results $(63,64)$. To determine total energy expenditure, energy expenditure should be measured over periods of days or at least $24 \mathrm{~h}$. Respiratory chambers are used to assess 24 -h energy expenditure (50). Recently the doubly labelled water technique has been introduced to measure total daily energy expenditure in free-living humans (65). Studies on validation of this technique show an accuracy within $5-10 \%$ relative to data derived by indirect calorimetry for subjects living in metabolic chambers (66-68). Due to the high cost of oxygen-18, the doubly labelled water technique is not suitable for large-scale epidemiological studies (67). 
While a lot of data are reported on measurement of resting energy expenditure in cancer patients, only few studies are published in order to explain the possible changes in metabolism. It will be evident that body composition is the most important determinant of REE $(50,51)$. Therefore it is important to consider changes in body composition induced by the presence of the tumor. Numerous studies were performed to examine the relationship between REE and the 2 components of body mass, namely the fat mass (FM) and the fat free mass (FFM). Overall, the variation in the size of the FFM compartment explained $60-85 \%$ of the variation in REE as reviewed by Cunningham (69). Nelson et al. concluded (70) that FM explained only a small part of the variation remaining in REE after accounting for FFM because of its low specific rate of metabolic rate. Only when FM became large, it contributed significantly to energy expenditure.

The presence of the tumor influences metabolism as has been demonstrated in experimental animal studies $(2,3)$. Specific tumor characteristics such as histology, tumor size or stage were studied as possible determinants of REE. Arbeit et al. (58) demonstrated that cancer patients with localized and extensive disease had a significantly enhanced REE compared to healthy controls. After tumor resection, all patients had a postoperative drop in their REE, which was remarkably well correlated with the measured tumor volume (58). However, the size of the tumor is a poor parameter for tumor growth rate and activity: tumor growth is the net result of cell formation and cell loss. Not only cell formation, but also the rate of cell loss is a major determinant of clinical growth rate (71). Fredrix et al. investigated the influence of tumor stage and tumor localization on REE. No significant differences in tumor stage or localization were demonstrated between hypermetabolic and normometabolic lung cancer patients by Fredrix et al. (60). She also investigated REE in patients with newly detected gastrointestinal tumors (62). There was no evidence that tumor type (gastric or colorectal) or tumor stage was important in relation to an increase in REE in these cancer patients. No data have been published until now about the influence of histology on REE.

Especially in lung cancer patients, pulmonary function has to be considered to explain the elevation of REE. Smoking behavior is an important risk factor for the development of lung cancer. A subgroup of smokers will develop airflow obstruction as well (72). Elevation of REE has been described in patients with disturbed pulmonary function (73-75). Patients with chronic obstructive pulmonary disease (COPD) appeared to have an increased REE. Several studies investigated the hypothesis that hypermetabolism in COPD patients is due to an increased energy consumption of breathing but convincing evidence has not yet been provided $(76,77)$. However, Fredrix et al. (60) did not find any significant influence of pulmonary function on REE in lung cancer patients:

Conflicting studies have been published about smoking behavior and the effects on energy expenditure. Hofstetter et al. suggested that smoking would influence energy 


\section{Chapter 1}

expenditure by stimulation of the sympathic nervous system. A significant elevation of 24-h energy expenditure was associated with smoking but no effects on REE were seen the morning after a day with cigarette smoking (78). Some studies reported a decrease of REE after smoking cessation $(79,80)$, while others found no effect $(81,82)$. The increase in REE in lung cancer patients could not be explained by smoking behavior as demonstrated by Fredrix et all. (60).

In conclusion, an increased REE has been demonstrated in lung cancer patients. However, only limited data are available about the prevalence of an enhanced REE in lung cancer patients. Moreover, there are limited data on energy intake in lung cancer patients related to energy expenditure. Therefore both energy intake and energy expenditure need to be investigated in a large group of lung cancer patients. Until now no explanation has been found for the disturbed energy balance in lung cancer. Based on experimental studies, the influence of inflammatory mediators e.g. cytokines on metabolic derangements has been suggested. Further studies are needed to investigate a possible relationship between energy expenditure and inflammatory state in cancer patients.

\section{Inflammation and metabolic derangements in animals}

Experimental studies have demonstrated a possible role for inflammatory mediators on metabolic derangements in tumor bearing animals. Key roles are attributed to the pleiotropic cytokines Tumor Necrosis. Factor (TNF)- $\alpha$, Interleukin (IL)-I, IL-6 and Interferon (IFN)- $\gamma$ (83-103). These four cytokines often share common sites of biosynthesis as well as overlapping biologic functions.

Cerami et al. (104) initially isolated TNF- $\alpha$ when studying why rabbits with trypanosomiasis developed a marked hypertriglyceridemia together with a marked loss of body weight. The native structure of TNF consists of a trimer with a total molecular mass of $52 \mathrm{kDa}$ (105). TNF- $\alpha$ was shown to effectively inhibit the enzyme lipoprotein lipase in adipocytes (106). The metabolic derangements of cancer patients could be reproduced by injecting rats with sublethal doses of recombinant human TNF twice daily (107). Anorexia, weight loss, depletion of whole body protein and lipid stores, reduction of red blood cell mass, leucocytosis and tissue inflammation occurred in the $\mathrm{TNF}$-injected rats, while sham-injected pairfed controls lost weight but did not develop these clinical features. However, with continued administration, the animals became resistant or tolerant, to the cachectic effects and regained normal food intake and gained weight $(108,109)$. When TNF- $\alpha$ was administered by either continuous infusion or by implanting a tumor genetically engineered to continually produce TNF- $\alpha$, progressive cachexia and death were observed $(107,108)$. More recent studies have shown that hypertriglyceridemia is the result of the stimulation of hepatic lipogenesis, rather than the inhibition of lipoprotein lipase (110). TNF- $\alpha$ together with IL-1 increased plasma triglycerides by 
stimulating hepatic lipogenesis and the production of very-low-density lipoprotein $(83,111)$. Other cytokines, including $\mathrm{IL}-1 \alpha$, Interferon- $\gamma$, Leukaemia Inhibiting Factor (LIF) and IL-6 have been demonstrated to decrease lipoprotein lipase activity in adipose tissue (84-85), while IL-1, IL-6 and IFN- $\alpha$ were demonstrated to increase hepatic lipogenesis as well $(87,88)$.

Chronic administration of $\mathrm{L}-1$ also produces body wasting $(89,90)$. Like TNF- $\alpha$, IL-1 has been shown to enhance hepatic protein synthesis and acute phase responses. Along with the cachectic changes seen with IL-1 this may support its role in the pathogenesis of cachexia. Gelin et al. (90) noted that an anti-IL-1 receptor monoclonal antibody in tumor bearing animals decreased tumor growth, attenuated anorexia and preserved body fat stores. Moldawer et al. (91) reported that doses of IL-1 one tenth of that required to cause pyrexia were capable of reducing food intake in mice. However, these authors were unable to demonstrate elevatedl levels of either TNF- $\alpha$ or IL-1 in tumor bearing animals. Convincing evidence for the involvement of IL-6 in experimental cancer cachexia in adenocarcinoma bearing mice was presented by Strassmann et al. $(92,93)$. Increasing levels of IL-6 correlated with the development of cachexia in mice with colon-26 adenocarcinoma. The cachectic syndrome was prevented when IL-6 monoclonal antibodies were injected (92). The colon-26 adenocarcinoma cells produced large quantities of IL-6 in vivo and their production was $\mathrm{IL}-1$ dependent. Infiltrating cells reacting to the tumor margins produced IL-1 locally, which in turn stimulated the tumor cells to release IL-6. Thus a positive feedback was observed between host macrophages and tumor cells resulting in increased systemic IL-6 release and consequently in metabolic effects (102). Further research by Strassmann et al. (94) revealed effects of suramin on IL-6 levels. Suramin inhibits the binding of IL-6 to its cell surface receptor and the cancer associated wasting in mice with the colon-26 adenocarcinoma. In line with these data it was shown that mice injected with IL-6 cDNA transfected Lewis lung carcinoma cells, showed an unaltered net tumor growth rate but IL-6 release from the Lewis lung carcinoma cells caused weight loss and shortened survival compared to mice transplanted with wild type Lewis lung carcinoma cells (95). Animal studies have also indicated a role for IFN- $\gamma$ in producing cachexia $(96,97)$. However, its effects were only transient. Matthys et al $(98,99)$ demonstrated that fat loss was enhanced by IFN $-\gamma$ and antagonized by antiIFN- $\gamma$ antibody. Anti-IFN- $\gamma$ treatment inhibited tumor growth and counteracted the cachectic wasting syndrome. Taken together these data demonstrate that a complex network of cytokines is responsible for the development of metabolic derangements and subsequent weight loss in animals. The cytokines have multiple physiologic effects both as cellular regulators involved in the inflammatory response and host defense against the tumor as well as stimulation of tumor growth. 


\section{Measurement of inflammation in humans}

\subsection{TNF- $\alpha$ and TNF-receptors}

Based on the experimental animal studies, many investigators have tried to detect TNF- $\alpha$ in peripheral blood of cancer patients. However, conflicting results are reported regarding the presence of TNF- $\alpha$ in peripheral blood (100-102). Biologically active TNF- $\alpha$ is difficult to detect because of its short half-time in the circulation $\left(T^{1 / 2}= \pm 10 \mathrm{~min}\right.$.) which makes detection dependent on frequency of sampling. In addition, the inconsistency in observed TNF data can be explained by formation of complexes of TNF with TNF-receptors $(103,111)$. TNF-receptors are present on the majority of cells, except for erythrocytes and unstimulated T-lymphocytes (105). Two distinct types of TNF-receptors have been fully identified: one receptor of $55 \mathrm{kDa}$ (TNF-R55) and a $75 \mathrm{kDa}$ receptor (TNF-R75). There is no homology between the intracellular parts of these two TNF receptors, which suggests that the signal pathways are different $(105,112)$. Although the presence of the TNF receptor is a prerequisite for a biological effect of TNF- $\alpha$, there is no correlation between the number of receptors and the magnitude of the response, or even the direction of response. The use of agonistic antibodies or high concentrations of hTNF muteins suggests that, in most cases, only TNF-R55 triggering is responsible for cytotoxic activity or enhanced expression of adhesion molecules on endothelial cells (113-116). However, Heller et al. suggested that TNF-R75 might be involved in the process of cytotoxicity as well (117) and others demonstrated the involvement of both TNF-receptors in the regulation of intercellular adhesion molecule (ICAM)-1 expression by HL 60 human promyelocytic leukaemia cells in vitro (118). Recent data indicate that TNF-R75 plays a central role in responses to membrane-bound TNF (119).

Soluble forms of the extracelluar domain of these TNF-receptors are shed by proteolytic cleavage of the membrane receptor and have been found in human serum, urine and other body fluids (105). TNF administration induces increased shedding of the receptors. Soluble (s) TNF-receptors reflect inflammatory activity. These molecules are considered to function as anti-inflammatory agents since they are able to catch free circulating TNF- $\alpha$ in plasma and to neutralize it.

Enhanced levels of both sTNF-receptors have been described in patients with various types of cancer (120-124). Both the incidence and the extent of increase of both sTNF-receptors was correlated with the stage of disease (120). Enhanced levels of sTNF-R55 were related with weight loss in haematological malignancies (122). Langkopf et al. (124) demonstrated that renal cell carcinoma patients with low pretreatment levels of sTNF-receptors had a longer progression-free survival compared to patients with high levels of sTNF-receptors. The source of these enhanced levels of both sTNF-receptors is still unknown. Gatanaga et al. (125) reported that TNFR55 was the predominant form of the TNF-receptors spontaneously released by a 
human ovarian tumor cell line. Sheđding of TNF-receptors by tumor cells could enhance the systemic levels of both sTNF-receptors and could function in counteracting the antitumor effects of TNF- $\alpha(125,126)$. Another explanation for enhanced levels of circulating TNF-receptors could be the release of low amounts of pro-inflammatory cytokines by tumor cells into the circulation leading to systemic release of sTNF-receptors.

\subsection{Interleukin-6}

IL-6 is a cytokine with plurifold properties and with a molecular mass of approximately $26 \mathrm{kDa}$. IL-6 can be produced by T-cells, fibroblasts, monocytes and endothelial cells upon stimulation with a variety of stimuli. These stimuli include LPS, TNF- $\alpha$, IL-1, II-2, IFN-6 and various viruses $(127,128)$. IL-6 is involved in the regulation of immune responses, the acute phase response and haematopoiesis (129). IL-6 is related to other cytokines that include leukaemia inhibitory factor (LIF), oncostatin M (OSM), ciliary neutrophic factor (CNTF), IL-II and cardiotrophin-1 (CT-1). All these cytokines possess a similar helical structure (130). The human IL-6 receptor complex consists of an $80 \mathrm{kDa}$ Il-6 binding molecule termed IL-6R $\alpha$ and a signal transducer, gp 130 , which functions by associating with IL-6R $\alpha$ upon the binding of IL-6 to IL-6R $\alpha$ (129). The gp I30 is a common subunit and signal transducer among the IL-6 family of cytokines .

Enhanced levels of IL-6 in serum have been reported in patients with ovarian cancer, renal cell carcinoma, gastric carcinoma, various T-cell malignancies and lung cancer (131-136). Not only in serum, but also in ascites of ovarian cancer patients high levels of IL-6 were detected (137). IL-6 levels were related with stage of disease and prognosis in ovarian cancer and renal cell carcinoma (131-134), however Yanagawa et al. (135) could not detect differences in IL-6. levels in lung cancer patients with or without metastases, but IL-6 levels were related with the presence of the acute phase response:

\subsection{Interleukin-8}

Interleukin (IL)-8 is an $8 \mathrm{kD}$ chemokine, originally isolated from LPS-stimulated peripheral blood mononuclear cells. II-8 belongs to the family of chemokines, among these are monocyte chemoattractant proteins (MCP-1,2 and 3) and RANTES (138-140). IL-8 is produced by alveolar macrophages, endothelial cells, monocytes, fibroblasts, T-lymphocytes and epithelial cells in response to a variety of stimuli, including LPS, TNF- $\alpha$, IL-1, IL-7 and hyperoxia (138-142). In addition to these cellular sources, IL- 8 is also produced by a variety of tumors, both constitutively 
and in response to cytokines $(143,144)$. IL- 8 has both a chemotactic and angiogenic function. IL-8 is chemotactic for neutrophils as well as for T-lymphocytes and stimulates the release of superoxide anions and lysosomal enzymes from neutrophils. IL-8 was recently found to be a mediator of angiogenesis $(145,146)$. By using neutralizing antibodies, Smith et al. demonstrated that IL-8 accounted for $42 \%$ to $80 \%$ of the angiogenic activity in the NSCLC specimens. investigated (145).

IL-8 downregulates its own receptor expression. More than $90 \%$ of IL-8 receptors are internalised within 10 minutes of IL- 8 binding. Following internalisation the IL8 molecule is slowly degraded by lysosomal enzynnes and the digested form is exocytosed from the cell. By liberating the receptors, from IL-8, the downregulated IL-8 receptors are quickly re-expressed on the cell membrane. This rapid turnover may be important for the chemotactic responses of neutrophils (147).

Increased levels of IL- 8 have been demonstrated in several pulmonary diseases e.g. pneumonia, sarcoidosis, idiopathic pulmonary fibrosis, asthma, adult respiratory distress syndrome and COPD (148).

\subsection{Adhesion molecules}

Adhesion molecules expressed on vascular endothelium and on circulating leucocytes play an important role in the inflammatory response by regulating adhesion of leucocytes to vascular endothelial cells, transmigration through endothelium and cell-cell interactions in the immune: response (149-151). Three groups of adhesion molecules mediate the adhesive interactions: the selectins, the integrins and the immunoglobulin supergene family. E-selectin (or Endothelial Leucocyte Adhesion Molecule-1) is a member of the selectin family of adhesion molecules and is expressed upon cytokine stimulation, both in vitro and in vivo, on endothelial cells only (152). The ligands for E-selectin include sialyl Lewis X (sLeX), present on neutrophils and macrophages, and a similar if not identical carbohydrate on a subset of memory T-cells $(153,154)$. Besides membrane bound Eselectin, also soluble E-selectin exists. Endothelial cells expressing E-selectin were shown to shed the extracellular part of E-selectin molecules (152). sE-selectin was found to be constitutively present in plasma of healthy individuals. Intercellular Adhesion Molecule (ICAM)- 1 and Vascular cell Adhesion Molecule (VCAM)-1 belong to the immunoglobulin supergene family $(149,151)$. ICAM- 1 binds to two integrins belonging to the $6_{2}$ subfamily, CDI1a/CDI8 (leucocyte function-associated antigen (LFA)-1) and CD11b/CD18. (MAC-1), both expressed by leucocytes (155), while the ligand for VCAM-1 is the integrin, very late antigen (VLA)-4. The cell surface expression of ICAM- 1 and VCAM- 1 is upregulated following activation during inflammatory responses. ICAM-1 is expressed on endothelial cells, epithelial cells, fibroblasts, leucocytes and many tumor cells $(149,151)$. VCAM-1 is also widely distributed on endothelial cells, epithelial cells, macrophages and dendritic 
cells $(149,151)$. The adhesion molecules ICAM-1 and VCAM-1 are shed by cells expressing these molecules and sICAM-1 and sVCAM-1 are present in plasma of healthy individuals $(156,157)$.

Elevated levels of sICAM-1 and normal levels of sE-selectin in cancer patients have been demonstrated in several studies (158-164), but there is limited information on levels of soluble VCAM-1 in blood of cancer patients (164). The significance of adhesion molecule shedding is not clear but it may have profound implications for tumor metastasis. Shedding of ICAM-1 by circulating tumor cells may allow their escape from surveillance by cytotoxic $T$ cells and natural killer cells and thus promote metastasis. Otherwise shedding of adhesion molecules by activated endothelial cells may prevent the adhesion of tumor cells to endothelium at metastatic sites (164).

\subsection{Acute Phase Proteins}

The systemic acute phase response involves a complex cascade of synthesis and secretion of both cytokines and hepatocyte-derived acute phase proteins. Normally the acute phase response lasts only a few days, but in cases of chronic or recurrent inflammation, a continuation of the acute phase response may contribute to the underlying tissue damage that accompanies the disease, and may also lead to further complications, for example cardiovascular diseases or protein deposition diseases such as reactive amyloidosis (165). The tissue macrophage or blood monocyte is commonly associated with the cascade of events during the acute phase response. Activated macrophages produce the cytokines IL-1, IL-6 and TNF- $\alpha$ which are the most important inducers of the acute phase response (166). Other inducers of the acute phase response are IFN- $\gamma$, leukaemia inhibitory factor (LIF), oncostatin $M$ (OSM), ciliary neutrophic factor (CNTF), transforming growth factor $\beta$ (TGF- $\beta$ ), glucocorticoids and IL-11 (165). Most acute phase proteins are induced between $50 \%$ and several-fold over normal levels. The changes in plasma proteins are variable and probably reflect differences in the amount of each protein that is necessary to participate effectively in the acute phase response. Two acute phase proteins have been investigated in the present study, namely $\mathrm{C}$-reactive protein (CRP) and lipopolysaccharide-binding protein (LBP).

CRP is a pentraxin, a protein with a characteristic pentameric organization of identical subunits arranged as single and double annular pentagonal discs, respectively (167). CRP was originally named for its ability to bind the Cpolysaccharide of Pneumococcus and has a number of calcium-dependent binding specificities (165). It acts as an opsonin for bacteria, parasites and immune complexes, and can activate the classical pathway of complement. IL-6 is the main inducer of CRP mRNA transcription in the liver (168). 


\section{Chapter I}

LBP is a $60 \mathrm{kDa}$ glycoprotein which facilitates binding of lipopolysaccharide (L.PS) to CD14, a newly described receptor for LPS $(169,170)$. LBP is found in normal serum or plasma in the $5-10 \mu \mathrm{g} / \mathrm{ml}$ range. LBP has a binding site for lipid $\mathrm{A}$, thus binding with high affinity to LPS from rough and smooth form bacteria. The lipid A portion of LPS is responsible for most of the biological effects of LPS (171). LBP is mainly produced by hepatocytes, but has also been demonstrated in lung, kidney, heart and spleen tissue (172). In serum or plasma, the association of LPS with LBP is transient (173). Binding of the LPS-LBP complex to CD14 on monocytes/macrophages results in an enhanced release of inflammatory mediators. An enhanced acute phase response has frequently been observed in patients with cancer. It has long been recognized that with tumor progression an acute phase response may develop. However, not all patients with metastatic disease have an increased acute phase response (174). Fearon et al. found that the strongest predictor of shortened survival was the degree of acute phase response at the time of diagnosis in colon cancer patients (175). Fearon also observed in weight losing cancer patients that the presence of an acute phase response was associated with an accelerated loss of the vital body cell mass (174). The present study will further investigate the role of the acute phase response in lung cancer patients and the possible relationship with the disturbed energy balance. 


\section{Aim of the study}

The aim of the present study was to assess the disturbed energy balance in lung cancer patients and to investigate the putative relationship between metabolic parameters and inflammatory mediators in lung cancer. To this end, the following studies were performed.

1. The incidence of the disturbed energy balance was investigated in patienis with newly detected lung cancer. Possible determinants were investigated.

2. The presence of inflammation was assessed in patients with newly detected lung cancer. To this end inflammatory mediators were measured in plasma, in bronchoalveolar lavage fluid and the expression of inflammatory mediators was investigated on resection specimens of NSCLC patients.

3. A possible relationship between the metabolic disturbances and inflammatory mediators in NSCLC patients was investigated.

4. Metabolic parameters were investigated in NSCLC patients before and 3,6 and 12 months after surgery.

5. Metabolic parameters and inflammatory mediators were assessed in SCLC patients before and after chemotherapeutic treatment. 


\section{References}

1. DeWys WD, Begg D, Lavin PT, et al. Prognostic effect of weight loss prior to chemotherapy in cancer patients. Am. J. Med. 1980; 69:491-497

2. Kern KA, Norton JA. Cancer Cachexia. J.P.E.N. 1988; 12:286-295

3. Norton JA, Peacock JL, Morrison SD. Cancer cachexia. CRC Crit. Rev, Oncol./Hematol. 1987: 7:289-327

4. Warren S. The immediate cause of death in cancer. Am. J. Med. Sci. 1932; 184:610-616

5. Van Eys J. Effect of nutritional status on response to therapy. Cancer research (suppl.) 1982; $42: 747 \mathrm{~s}-753 \mathrm{~s}$

6. Costa G, Lane WW, Vincent RG, Siebold JA, Aragon M, Bewely PT. Weight. loss and cachexia in lung cancer. Nutrition and Cancer 1980;2:98-103

7. Coiffier B, Gisselbrecht C, Vosse JM, Herbrecht R, Bosly A, Armitage JO. Prognostic factors in aggressive malignant lymphomas: description and validation of a prognostic index that could identify patients requiring a more intensive therapy. J. Clin. Oncol. 1991; 9:211-219

8. Meguid MM, Debonnis D, Meguid V. Nutritional support in cancer. Lancet 1983; ii:230-231

9. Hickman DM, Miller RA, Rambeau JL, et al. Serum albumin and body weight as predictors of postoperative course in colorectal cancer. J P E N 1980; 4:314-316

10. Conti S, West JP, Fitzpatrick HF. Mortality and morbidity after eosophagogastrectomy for cancer of the esophagus and cardia. Am Surg 1977; 43:92-96

11. Buccheri G, Ferrigno D. Prognostic factors in lung cancer: tables and comments. Eur Resp J 1994; 7:1350-1364

12. Lagakos SW. Prognostic factors for survival time in inoperable lung cancer. In: Straus MJ, ed. Lung cancer: clinical diagnosis and treatment. NY: Grune \& Stratton, Inc. 1977:271-280

13. Lanzotti VJ, Thomas DR, Boyle LE, et al. Survival with inoperable lung cancer. Cancer 1977; 39:303-313

14. Theologides A. Cancer cachexia. Cancer 1979; 43:2004-2012

15. Balducci L, Hardy C. Cancer and nutrition: A review. Compr Ther 1987; 13:60-74

16. Ovesen L. Hannibal J, Mortensen EL. The interrelationship of weight loss, dietary intake and quality of life in ambulatory patients with cancer of the lung, breast and ovary. Nutr Cancer 1993; 19: 159-167

17. Kokal WA. The impact of antitumor therapy on nutrition. Cancer $1985 ; 55: 273-277$

18. Baines M. Nausea and vomitting in patients with advanced cancer. J Pain Sympt Management $1988 ; 3: 811-85$

19. Padilla G. Psychological aspects of nutrition and cancer. Surg Clin North 1986; 60:1121-1129

20. Theologides A. Anorexia producing intermediary metabolites. Am J Clin Nutr 1976; 29:552558

21. Grossmar SP. The neuroanatomy of eating and drinking behavior. Chapter 14 in : Neuroendocrinology, Eds. Krieger D and Hughes JC. Sinauer Associates Inc. Publ. Sunderland, Massachusetts, 1980

22. Von Meyenfeldt MF, Chance WT. Fischer JE. Correlation of changes in brain indoleamine metabolism with onset of anorexia in rats. Am J Surg 1982; 143:133-138.

23. Hellerstein MK, Meydani SN, Meydani M, Wu K, Dinarello. Interleukin-1 induced anorexia in the rat. Influence of prostaglandins. J Clin Invest 1989; $84: 228.235$

24. Bodnar RJ, Pastrenak GW, Mann PE. Mediation of anorexia by human recombinant tumor necrosis factor through a peripheral action in the rat. Cancer Res 1989: 49:6280-6284

25. Langstein HN, Doherty GM. Fraker DL, Buresh CM, Norton JA. The role of $\gamma$-Interferon and tumor necrosis factor- $\alpha$ in an experimental rat model of cancer cachexia. Cancer Res 1991: $51: 2302-2306$ 
26. Turton MD, O'Shea D, Gunn I, Beak SA, Edwards CMB, Meeran K, Choi SJ, Taylor. A role for glucagon-like peptide-1 in the central regulation of feeding. Nature 1996; 379:69-72

27. Novak U, Wilks A, Buell G, McEwens S. Eur J Biochem 1987; 164:557-558

28. Warnold I, Lundholm K, Schersten T. Energy balance and body composition in caner patients. Cancer Res 1978; 38:1801-1807

29. Axelrod L, Costa G. Contribution of fat loss to weight loss in cancer. Nutr Cancer 1980; 2:8183

30. Costa G. Cachexia, the metabolic component of metastatic disease. Cancer Res 1977; 37:2327. 2335

31. Shaw JHF, Wolfe RR. Fatty acids and glycerol kinetics in septic patients and in patients with gastrointestinal cancer: the response to glucose infusion and parenteral feeding. Ann Surg 1987: 205:368-376

32. Legaspi A, Jeevanandam M, Starnes HF, Brennan MF. Whole body lipid and energy metabolism in the cancer patient. Metabolism 1987; 10:958-963

33. Dilman VM. Bernstein LM, Ostraumona MN. Peculiarities of hyperlipidemia in tumor patients. Br J Cancer 1981; 43:637-643

34. Edmonston JH. Fatty acid mobilization in cancer patients. Cancer 1966; 19:277-280

35. Thompson MP, Koons JE, Tan ET. Modified lipoprotein lipase activities, rates of lipogenesis and lipolysis as factors leading to lipid depletion in L57BC mice bearing the preputial gland tumor ESR-586. Ann Surg 1986; 204:637-642

36 Shaw JHF, Wolfe RR. Glucose and urea kinetics in patients with early and advanced gastrointestinal cancer: the response to glucose infusion, parenteral feeding, and surgical resection. Surgery 1986; 101:181-191

37. Waterhouse C, Jeanpetre $\mathrm{N}$, Keilson J. Insulin resistance in patients with progressive malignant disease. Cancer Res 1979; 39:1968-1972

38. Marks PA, Bishop JS. The glucose metabolism of patients with malignant disease and normal subjects as studied by means of an intravenous glucose tolerance test. J Clin invest 1956; $35: 254-260$

39. Lundholm K, Edstrom S, Karlberg 1, et al. Glucose turnover, gluconeogenesis from glycerol, and estimation of net glucose cycling in cancer patients. Cancer 1982; 50:1142-1150

40. Kurzer M. Meguid M. Cancer and protein metabolism. Surg Clin North Am 1986; 66:969-981

41. Jeevanandam M, Lowry SF, Horowitz GD. Cancer cachexia and protein metabolism. Lancet 1984: 1:1423-1426

42. Fearon KCH, Hansell DT, Preston T, Plumb JA, Davies J, Shapiro D. Shenkin A, Calman $\mathrm{KC}$, Burns. HJG. Influences of whole body protein turnover rate on resting energy expenditure in patients with cancer. Cancer Res 1988; 48:2590-2595

43. Lundholm K. Bylund AC, Holm J. Skeletal muscle metabolism in patients with malignant tumours. Eur J Cancer 1976; 12:465-473

44. Zhang Y. Proenca R, Maffei M. Barone M. Leopold L, Friedman J. Positional cloning of the mouse obese gene and its human homologue. Nature 1994; 372:425-432; Correction: Nature 1995; $374: 479$

45. Frederich RC et al, Expression of ob mRNA and its encoded protein in rodents; impact of nutrition and obesity. J Clin Invest 1995; 96: 1658-1663

46. Halass JL, Gajiwala KS, Maffei M, Cohen SL, Chait BT, Rabinowitz D, Lallone RL, Burley SK, Friedman JM. Weight-reducing effects of the plasma protein encoded by the obese gene. Science $1995 ; 269: 543-546$

47. Campfield LA, Smith FJ, Guisez Y, Devos R, Burn P. Recombinant mouse ob protein: evidence for a peripheral signal linking adiposity and central neural networks. Science 1995; 269:546-549 


\section{Chapter I}

48. Pelleymounter MA, Cullen MJ, Baker MB, Hecht R, Winters D, Boone T, Collins F. Effects of the obese gene product on body weight regulation in ob/ob mice. Science 1995; 269:540-543

49. Burke M, Bryson EI, Kark AE. Dietary intakes, resting metabolic rates, and body composition in benign and malignant gastrointestinal disease. Br Med J 1980; 26:211-215

50. Ravussin E, Lillioja S, Anderson TE, Christin L, Bogardus C. Determinants of 24 hour energy expenditure in man: methods and results using a respiration chamber. J Clin Invest 1986; 78: $1568-1578$

51. Ravussin E, Bogardus C. Relationship of genetics, age and physical fitness to daily energy expenditure and fuel utilization. Am J Clin Nutr 1989; 49:968-975

52. Brennan M. Uncomplicated starvation versus cancer cachexia. Cancer Res 1977; 37:2359-2364

53. Dempsey DT, Feurer ID, Knox LS, Crosby LO, Buzby GP, Mullen JL. Energy expenditure in malnourished gastrointestinal cancer patients. Cancer 1984; 53:1265-1273

54. Hansell DT, Davies JWL, Burns HJG. The effects on resting energy expenditure of different tumor types. Cancer 1986; 58:1739-1744

55. Knox LS, Crosby LO, Feurer ID. Energy expenditure in malnourished cancer patients. Ann Surg 1983; 197:152-163

56. Nixon DW, Kutner M, Heymsfield S, Foltz AT, Carty C, Seitz S, Casper K, Evans WK, Jeejeebhoy KN, Daly JM. Resting energy expenditure in lung and colon cancer. Metabolism 1988; 37: 1059-1064.

57. Lindmark L, Bennegard K, Eden E, Ekman L, Schersten T, Svaninger G, Lundholm K. Resting energy expenditure in malnou-rished. patients with and without cancer: Gastroenterology 1984; 87:402-408

58. Arbeit JM, Lees DE. Brennan MF. Resting energy expenditure in controls and cancer patients with localized and diffuse disease. Ann Surg 1984; 199:292-298

59. Russell D, Shike M, Marliss E, Detsky A, Shepherd F, Feld R, Evans W, Jeejeebhoy K. Effects of parenteral nutrition and chemotherapy on the metabolic derangements in small cell lung cancer. Cancer Res 1984; 44:1706-1711

60. Fredrix EWHM, Wouters EFM, Soeters PB, van der Aalst ACJM, Kester ADM, von Meyenfeldt MF, Saris WHiM. Resting energy expenditure in non-small, cell lung cancer patients. Cancer 1991; 68:1616-1621

61. Harris J, Benedict F. A biometric study of basal metabolism in man. Washington DC: Carnegie Institution 1919. Publication 279

62. Fredrix EWHM, Soeters PB, Rouflart MMJ, von Meyenfeldt MF, Saris WHM. Resting energy expenditure in patients with newly detected gastric and colorectal cancer. Am J Clin Nutr 1991: $53: 1318-1322$

63. Warnold I, Lundholm K, Schersten T. Energy balance and body composition in cancer patients. Cancer Res 1978; 38:1801-1807

64. Edström S, Bennegard K, Edén $\mathrm{E}$, Lundholm K. Energy and tissue metabolism in patients with cancer during nutritional support. Arch ottolaryngol 1982; 108:697-699

65. Goran MI, Poehiman ET, Johnson RK. Energy requirements across the life span: new findings based on measurement of tota! energy expenditure with doubly labeled water. Nutrition Res $1995 ; 15: 115-150$

66. Schoeller DA, Fjeld CR. Human energy metabolism: what have we learned from the doubly labeled water method. Ann Rev Nutr 1991; I 1:355-373

67. Prentice AM. Applications of the ${ }^{2} \mathrm{H}_{2}{ }^{18} \mathrm{O}$ method in free-living humans. Proc Nutr Soc 1988; 47:258-269

68. Schoeller DA, Racette SB. A review of filed techniques for the assessment of energy expenditure. J Nutr 1990; 120 suppl.: 1492-1495

69. Cunningham JJ. Body composition as a. determinant of energy expenditure: a synthetic review and a proposed general prediction equation. Am J Clin Nutr 1991: 54:963-969: 
70. NeIson KM, Weinsier RL, Long CL, Schutz Y. Prediction of resting energy expenditure from fat-free mass and fat mass Am J Clin Nutr 1992; 56:848-856

71. Tinnemans MMFJ, Lenders MHJH, ten Velde GPM, Ramaeckers FCS, Schutte B. Alterations in cytoskeletal and nuclear matrix associated protein during apoptosis. Eur J Cell Biol 1995; 68:35-46

72. Lange P, Nyboe J, Appleyard M, Jensen G, Schnohr P. Relationship of the type of tobacco and inhalation pattern to pulmonary and total mortality. Eur Resp J 1992; 5:1111-1117

73. Schols AMWJ, Fredrix EWHM, Soeters PB, Westerterp KP. Wouters EFM. Resting energy expenditure in patients with chronic obstructive pulmonary disease. Am J Clin Nutr 1991; 54:983-987

74. Goldstein S, Askanazi J, Weissman C, Thomashow B, Kinney J. Energy expenditure in patients with chronic obstructive pulmonary disease. Chest 1987; 91:222-224

75. Ryan CF, Road JD, Buckley PA, Ross C, Whittaker JS. Energy balance in stable malnourished patients with chronic obstructive pulmonary disease. Chest 1993; 103:1038-1044

76. Donahoe M, Rogers RM, Wilson DO, Pennock BE. Oxygen consumtion of the respiratory muscles in normal and malnourished patients with Chronic Obstructive Pulmonary Disease. Am Rev Respir Dis 1989; 94:1260-1263

77. Stridhar MK, Carter R, Lean MEJ, Banham SW. Resting energy expenditure and nutritional state of patients with increased oxygen cost of breathing due to emphysema, scoliosis and thoracoplasty. Thorax 1994; 49:781-785:

78. Hofstetter A, Schutz $\mathrm{Y}$, Jequier E. Increased $24 \mathrm{~h}$ energy expenditure in cigarette smokers. N Engl J Med 1986; 314:79-82

79. Moffatt RJ, Owens SG. Cessation from smoking: changes in body weight, body composition, resting metabolism and energy consumption. Metabolism 1991; 40: 465-470

80. Dallosso HM, James WPT. The role of smoking in the regulation of energy balance. Int $\mathrm{J}$ obes $1984 ; 8: 365-375$

81. Stamford BA, Matter S, Fell RD, Papanek P. Effects of smoking cessation on weight gain, metabolic rate, caloric consumption, and blood lipids. Am J Clin Nutr 1986; 43:486-494

82. Burse RL, Bynum GD, Pandolf K.B, Goldman RF, Sims EAH. Danforth ER. Increased appetite and unchanged metabolism upon cessation of smoking with diet held constant. Physiologist 1975; 18:157

83. Feingold KR, Soued M, Adi S, Staprans I. Effect of Interleukin- $\mathbf{I}$ on lipid metabolism in the rat: similarities to and differences from tumor necrosis factor. Arterioscler Thromb 1991; 11:495-500.

84. Patton JS, Shepard HM, Wilking H. Interferons and tumor necrosis factor have similar effects on 3T3 Ll cells. Proc Natl Ac Sci USA, 1986; 83:8313-8317

85. Greenberg AS, Nordan RP, McIntosh J. Interleukin 6 reduces lipoprotein lipase activity in adipose tissue of mice in vivo and 3 T3 Ll adipocytes: possible role for IL-6 in cancer cachexia. Cancer Res 1992; 52:4113-4116

86. Greenberg AS, Nordan RP, McINtosh J, Calvo JC, Scow RO, Jablons D. Interleukin 6 reduces lipoprotein lipase activity in adipose tissue of mice in vivo and in 3T3-LI adipocytes: a possible role for Interleukin 6 in cancer cachexia. Cancer Res 1992; 52:4113-4116

87. Feingold KR, Soued, M, Serio MK, Moser AH, Dinarello CA, Grunfeld C. Multiple cytokines stimulate hepatic lipid synthesis in vivo. Endocrinology 1989; 125:267-274

88. Grunfeld C, Adi S, Soued M, Moser AH, Fiers W, Feingold KR. Search for mediators of the lipogenic effects of tumor necrosis factor: potential role for IL-6. Cancer Res 1990: 50:42334238

89. Fong $\mathrm{Y}$, Moldawer, Marano M, et al: Cachectin/TNF or IL- $1 \alpha$ induces cachexia with redistibution of body proteins. Am J Physiol 1989; 25:R659-R665 


\section{Chapter I}

90. Gelin J, Moldawer LL, Lönnroth C, Sherry B, Chizzonite R, Lundholm K. Role of endogenous tumor necrosis factor $\alpha$ and Interleukin 1 for experimental tumor growth and the development of cancer cachexia. Cancer Res 1991; 51:415-421

91. Moldawer LL, Gelin J, Schersten T, Lundholm K. Circulating interieukin 1 and tumor necrosis factor during inflammation. Am J Physioll 1987; 253:R922-R928

92. Strassman G, Fong M, Kenney JS, Jacob CO. Evidence for the involvement of Interleukin 6 in experimental cancer cachexia. J Clin Invest 1992; 89:1681-1684

93. Strassman G, Jacob CO, Evans R, Beall D, Fong M. Mechanisms of experimental cancer cachexia, interaction between mononuclear phagocytes and colon-26 carcinoma and its relevance to IL-6 mediated cancer cachexia. J Immunol 1992; 148:3674-3678

94. Strassmann G, Fong M. Freter CE. Suramin interferes with Interleukin-6 receptor binding in vitro and inhibits colon-26-mediated experimental cancer cachexia in vivo. J Clin Invest 1993; 92:2152-2159

95. Ohe Y, Podack ER, Olsen KJ, Miyahara Y, Miura K, Saito H, Koishihara Y, Ohsugi Y, Ohira T, Nishio K, Saijo N. Interleukin-6 cDNA transfected Lewis Lung carcinoma cells show unaltered net tumour growth rate but cause weight loss and shorten survival in syngenic mice. Br J Cancer 1993; 67:939-944

96. Billiau A. Gamma-interferon: The match that lights the fire? Immunol. Today 1988; 9:37-40

97. Patton JS, Shephard HM, Wilking $\mathrm{H}$. Interferons and tumor necrosis factor have similar catabolic effects on 3T3LI cells. Proc Natl Acad Sci USA 1986; 83:8313-8317

98. Matthys P, Heremans H, Opdenakker G. Anti-interferon-gamma antibody treatment, growth of Lewis lung tumors in mice and tumor-associated cachexia. Eur J Cancer 1991; 27:182-187

99. Matthys P, Dukmans R, Proost P. Severe cachexia in mice inoculated with interferon-gamma producing tumor cells. Int J Cancer 1991; 49:77-82

100. Aderka D, Fisher S, Levo Y, Holtmann H, Hahn T, Wallach D. Cachectin/ tumor necrosis factor production by cancer patients. The Lancet 1985; $23: 1190$

101. Balkwill F, Osborne R, Burke F, Naylor S, Talbot D, Durbin H. Tavernier J. Evidence for tumour necrosis factor/cachectin production in cancer. The Lancet 1987; 28:1229-1232

102. Waage A, Espevik T, Lamvik J: Detection of TNF-like cytotoxicity in serum from patients with septicemia but not from untreated cancer patients. Scan J Immunol 1987; 24:739-744

103. Engelberts I, Möller A, Schoen GJM, van der Linden C, Buurman W. Evaluation of measurement of human TNF in plasma by ELISA. Lymphokine and cytokine Res 1991; 10:6976

104. Rouzer CA, Cerami A. Hypertriglyceridemia associated with Trypanosoma brucei infection in rabbits: role of defective triglyceride removal. Mol Biochem Parasitol 1980; 2:31-38

105. Fiers W. Tumor Necrosis Factor, characterization at the molecular, cellular and in vivo level. FEBS Lett 1991: 285:199-212

106. Beutler B, Mahoney J, Le Trang N, Kekala P, Cerami A. Purification of Cachectin, a lipoprotein lipase-suppressing hormone secreted by endotoxin-induced RAW 264.7 cells. J Exp Med 1985; 161:984-995

107. Tracey KJ, Wei H. Manogue KR, Fong Y, Hesse DG, Kuo GC, Beutler B, Cerami A, Lowry SF. Cachectin/Tumor necrosis factor induces cachexia, anemia, and inflammation. J Exp Med 1988: 167:1211-1227

108. Oliff A, Defeo Jones D, Boyer M. Martinez D, Kiefer D, Vuocolo G, Wolfe A, Socher SH. Tumors secreting human TNF/cachectin induce cachexia in mice. Cell 1987; 50:555-563

109. Langstein HN, Doherty GM, Fraker DL. The roles of interferon-gamma and tumor necrosis factor in an experimental rat model of cancer cachexia. Cancer Res 1991; 51:2302-2306

110. Grunfeld C. Gulli R, Moser AH, Gravin LA. Feingold KR. Tumor necrosis factor administration in vivo on lipoprotein lipase activity in various tissues of the rat. J Lipid Res $1989 ; 30: 579-585$ 
111. Engelberts I, Stephens S, Francot GJM, van der Linden CJ, Buurman WA. Evidence for different effects of soluble TNF-receptors on various TNF measurements in human biological fluids. The Lancet 1991; 338:515-516

112. Dembic Z, Loetcscher H, Gubler U, Pan CE, Lahm W, Gentz R, Brockhaus M, Lesslauer W. Two human TNF receptors have similar extracellular, but distinct intracellular, domain sequences. Cytokine 1990; 2:231-237

113. Tartaglia LA, Rothe M, Hu Y-F, Goeddel DV. Tumor necrosis factor's cytotoxic activity is signaled by the p55 TNF-receptor. Cell 1993; 73:213-216

114. Loetscher H, Stueber D, Banner D, Mackay F, Lesslauer W. Human tumor necrosis factor- $\alpha$ mutants with exclusive specificity for $55 \mathrm{kDa}$ or $75 \mathrm{kDa}$ TNF-receptor. J Biol Chem 1993; 268:26350-26357

115. Espevik T, Brockhaus M, Loetscher H, Nonstad U, Shalaby R. Characterization of binding and biological effects of monoclonal antibodies against a human Tumor Necrosis Factor receptor. J Exp Med 1990; 171:415-426

116. Tartaglia LA, Goeddel DV. Two TNF-receptors. Immunol Today 1992; 13:151-153

117. Heller RA, Song K, Fan N, Chang DJ. The p 70 Tumor Necrosis Factor receptor mediates cytotoxicity. Cell 1992; 70:47-56

118. Abe Y, Gatanaga M, Osuka Y, Kimura S, Burger RA, Granger GA, Gatanaga T. Role of 55and $75 \mathrm{kDa}$ Tumor Necrosis Factor membrane receptors in the regulation of intercellular adhesion molecule-1 expression by HL-60 human promyelocytic leukemia cells in vitro. J Immunol 1993; 150:5070-5079

119. Grell M, Zimmermann G, Hulser D, Pfizenmaier K, Scheurich P. TNF receptors TR60 and TR80 can mediate apoptosis via induction of distinct signal pathways. J Immunol 1994; 153:1963-1972

120. Aderka D, Engelmann H, Hornik V, Skornick Y, Levo Y, Wallach D, Kushtai G. Increased serum levels of soluble receptors for tumor necrosis factor in cancer patients. Cancer Res $1991 ; 51: 5602-5607$

121. Digel W, Porzsolt F, Schmid M, Herrman F, Lesslauer W, Brockhaus M. High levels of circulating soluble receptors for tumor necrosis factor in hairy cell leukemia and type B chronic lymphocytic leukemia. J Clin Invest 1992;89:1690-1693

122. Denz H, Orth B, Weiss G, Gallati H. Herrmann R. Huber P, Wachter H, Fuchs D. Serum soluble tumour necrosis factor receptor 55 is increased in patients with haematological neoplasia and is associated with immune activation and weight loss. Eur J Cancer 1993; 29a: $2232-2235$

123. Waage A, Liabakk N, Lien E, Lamvik J, Espevik T. p55 and p75 Tumor necrosis factor receptors in patients with chronic lymphocytic leukemia. Blood 1992; 10:2577-2583

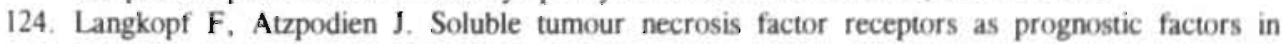
cancer patients. The Lancet 1994; 344:57-58

125. Gatanaga M. Grosen EA, Burger RA, Granger GA, Gatanaga T. Release of soluble TNF/LT receptors from a human ovarian tumor cell line ( $\mathrm{PA}-1)$ by stimulation with cytokines in vitro. Lymphokine Cytokine Res 1993; 12:249-253

126. Olsson I, Gatanaga T, Gullberg U, Lantz M. Granger GA. Tumour necrosis factor (TNF) binding proteins (soluble TNF receptor forms) with possible roles in inflammation and malignancy. Eur Cytokine Netw 1993; 4:169-180

127. Van Snick J. Interleukin-6: an overview. Ann Rev Immunol 1990; 8:253-278

128. Brach MA. Hermann F. Interleukin-6: presence and future. Int J Lab Res 1992; 22:143-15 !

129. Kishimoto T, Akira S, Taga T. Interleukin-6 and its receptor: a paradigm for cytokines. Science $1992 ; 258: 593-597$

130. Bazan JF. Haematopoietic receptors and helical cytokines. Immunol Today 1990; 11:350-354 


\section{Chapter I}

131. Plante M, Rubin SC, Wong GY. Interleukin-6 level in serum and ascites as al prognostic factor in patients with epithelial ovarian cancer. Cancer 1994; 73:1882-1888

132. Scambia G, Testa U, Benedetu Panici P. Foti E, Martucci R, Gadducci A, Perillo A, Facchini V. Peschle C, Mancuso S. Prognostic significance of interleukin 6 serum levels in patients with ovarian cancer. Br J Cancer 1995; 71:354-356

133. Blay JY, Negrier S, Combaret V, Attali S, Goillot E, Merrouche Y, Mercatello A, Ravault A, Tourani JM, Moskovtchencko JF. Philip T, Favrot M. Serum level of Interleukin 6 as a prognostic factor in metastatic renal cell carcinoma. Cancer Res 1992; 52:3317-3322

134. Dosquet C, Schaetz A, Faucher C, Lepage E, Wautier IL, Richard F, Cabane J. Tumour Necrosis Factor- $\alpha$, Interleukin-1B and Interleukin- 6 in patients with renal cell carcinoma. Eur J Cancer 1994; 30A: $162-167$

135. Yanagawa H, Sone S, Takahashi Y, Haku T, Yano S, Shinohara T, Ogura T. Serum levels of interleukin 6 in patients with cancer. Br J Cancer 1995; 71:1095-1098

136. Raziuddin S, Sheikha A, Abu-Eshy S, Al-Janadi M. Circulating levels of cytokines and soluble cytokine receptors in various T-cell malignancies. Cancer 1994; 73:2426-2431

137. Watson JM, Sensitaffar J, Berek JS, Martinez-Maza O. Constitutive production of Interleukin- 6 by ovarian cancer cell lines and by primary ovarian tumor cultures. Cancer Res 1990; 50:6959-6965

138. Yoshimura T, Maisushima K. Tanaka S, Robinson EA, Apella E, Oppenheim JJ, Leonard EJ. Purification of a human monocyte-derived neutrophil chemotactic factor that has peptide sequence similarity to other host defense cytokines. Proc: Natl Acad Sci, USA 1987; 84: 9233 9237

139. Standiford TJ, Kunkel SL, Basha MA, Chensue SW, Lynch JP III. Interleukin-8 gene expression by a pulmonary epithelial cell line. J Clin Invest 1990; 86:1945-1953

140. Baggiolini M, Bardwell 1, Sager R. Neutrophil-activating peptide-1/Interleukin-8, a novel cytokine that activates neutrophils. J Clin Invest 1989; 84: 1045-1049

141. Liebler JM, Kunkel SL, Burdick MD, Standiford TJ, Rolfe MW, Strieter RM. Production of IL- 8 and monocyte chemotactic peptide- 1 by peripheral blood monocytes, disparate responses to phytohemagglutinin and lipopolysaccharide. J Immunol 1994; 152:241-249

142. Metinko AP, Kunkel SL, Standiford TJ, Strieter RM. Anoxia-hyperoxia induces monocyte derived interleukin-8. J Clin Invest 1992; 90:791-798

143. Mizuno K, Sone S, Orino E, Mukaida N, Matsushima K. Ogura T. Spontaneous productiojn of interleukin- 8 by human lung cancer cells and its augmentation by tumor necrosis factor alpha and interteukin- 1 at protein and mRNA levels. Oncology $1994 ; 51: 467-471$

144. Hotta K. Hayashi K. Ishikawạ J. Tagawa M. Hashimoto K. Mizuno S, Suzuki K. Coding region structure of interleukin-8 gene of human lung giant cell carcinoma $\mathrm{LU} 65 \mathrm{C}$ cells that produce LUCT/Interleukin-8: Homogeneity in interleukin-8 genes. Immunol Let 1990; 24: $165-170$

145. Smith DR, Polverini PJ, Kunkel SL, Orringer MB, Whyte RI, Burdick MD, Wilke CA, Strieter RM. Inhibition of interleukin-8 attenuates anigiogenesis in bronchogenic carcinoma. J Exp Med 1994: 179:1409-1415

146. Koch AE, Polverini PJ, Kunkel SL, Harlow LA, DiPietro LA, Elner VM, Elner SG, Strieter RM. Interleukin- 8 as a macrophage-derived mediator of angiogenesis. Science 1992; 258:17981801 .

147. Samanta AK, Oppenheim J, Matsushima K. Interleukin 8 (monocyte-derived neutrophil chemotactic factor) dynamically regulates its own receptor expression on human neutrophils. J Biol Chem 1990: 265:183-189

148. Nicod LP. Cytokines, overview. Thorax 1993; 48:660-667

149. Springer TA. Adhesion receptors of the immune system. Nature 1990; 346:425-434

150. Bevilacqua MP. Endothelial-leukocyte adhesion molecule. Ann Rev Immunol 1993; 11:767-804 
151. Mackay C, Imhof B. Cell adhesion in the immune system. Immunol Today 1993; 13:224-230

152. Leeuwenberg JFM, Smeets EF, Neefkes J, Schaffer MA, Cinek T, Jeunhomme GMMA, Ahern TJ, Bururman WA. E-selectin and intercellular adhesion molecule 1 are released by activated human endothelial cells in vitro. Immunology 1992; 77:543-549

153. Picker L, Warnock RA, Burns Ar, Doerschuk CM, Berg EL, Butscher EC. The neutrophil selectin in LECAM-1 presents carbohydrate ligands to the vascular selectins ELAM-1 and GMP-140 (published erratum in Cell 1991; 20; 67: 1267) Cell 1991; 66:921-933

154. Brandley BK, Swiedler SJ, Robbins PW. Carbohydrate ligands of the LEC cell adhesion molecules. Cell 1990; 63:861-863

155. Diamond M, Staunton D, de Fougerolles A, Stacker S, Garcia-Aguilar J, Hibbs L, Springer TA. ICAM-1 (CD54): a counter receptor for MAC-1 (CD1/b/CD18), J Cell Biol 1990; 111:3129-3139

156. Gearing AJH, Hemmingway IK, Pigott R, Hughes J, Rees AJ, Cashman SJ. Soluble forms of vascular adhesion molecules, E-selectin, ICAM-1 and VCAM-1: pathological significance. Ann N Y Acad Sci 1992; 667:324-331

157. Rothlein R, Mainolfi EA, Czajkowski M, Marlin SD. A form of circulating ICAM-1 in human serum. J Immunol 1991; 147:3788-3793

158. Christiansen I, Gidlof C, Wallgren AC, Simonson B, Totterman TH. Serum levels of soluble intercellular adhesion molecule 1 are increased in chronic lymphocytic leukemia and correlate with clinical stage and prognostic markers. Blood 1994, 84: 3010-3016

159. Tsujisaki M, Imai K, Hirata H, Hanzawa Y, Masuya J, Nakano T, Sugiyama T, Matsui M. Hinoda Y. Yachi A. Detection of circulating intercellular adhesion molecule-I antigen in malignant diseases. Clin Exp immunol 1991; 85:3-8

160. Wolff JM, Stephenson RN, Chisholm GD, Habib FK. Levels of circulating Intercellular adhesion molecule-I in patients with metastatic cancer of the prostate and benign prostatic hyperplasia. Eur J Cancer 1995; 31A:339-341

161. Santarosa M, Favaro D, Quaia M, Spada A, Sacco C, Talamini R, Galligioni E. Expression and release of intercellular adhesion molecule-1 in renal-cancer patients. Int J Cancer 1995; $62: 271-275$

162. Gruss HJ, Dölken G, Brach MA, Mertelsmann R, Herrmann F. Serum levels of circulating ICAM-1 are increased in Hodgkin's Disease. Leukemia 1993, 7:1245-1249

163. Schwaeble W, Kerlin M, Meyer zum Büschenfelde KH, Dippold W. De novo expression of Intercellular Adhesion Molecule-I (ICAM-I, CD54), in pancreas cancer Int J Cancer 1993; 53:328-333

164. Banks RE, Gearing A.J, Hemingway IK, Norfolk DR, Perren TJ, Selby PJ. Circulating intercellular adhesion molecule (ICAM)-1, E-selectin and vascular cell adhesion molecule (VCAM)-1 in human malignancies. Br J Cancer 1993; 68:122-124

165. Steel DM, Whitehead AS. The major acute phase reactants: C-reactive protein, serum amyloid P component and serum amyloid A protein. Immunol Today 1994; 15:81-87

166. Baumann H. Gauldie J. The acute phase response. Immunol Today, 1994; 15:74-80

167. Gewurz H, Zhang XH, Lint TF. Structure and function of pentraxins. Current Opinion Immunol. 1995; 7:54-64

168. Heinrich PC, Castell JV, Andus T. Interleukin-6 and the acute phase response. Biochem J 1990: 265:621-636

169. Tobias PS, Soldau K, Ulevitch RJ. Isolation of a lipopolysaccharide-binding acute phase reactant from rabbit serum. J Exp Med 1986; 164:177-793

170. Schumann RR, Leong SR, Flaggs GW, Gray PW, Wright SD, Mathison JC, Tobias PS, Ulevitch RJ. Structure and function of lipopolysaccharide binding protein. Science 1990; 249:1429-1431 


\section{Chapter I}

171. Lynn WA, Golenbock DT. Lipopolysaccharide antagonists. Immunol Today 1992; 13:271-276

172. Wan Y, Freeswick PD, Khemlani LS, Kispert PH, Wang SC, Su GL, Billiar TR. Role d lipopolysaccharide (LPS), Interleukin-1, Interleukin-6, Tumor Necrosis Factor and dexamethasone in regulation of LPS-binding protein expression in normal hepatocytes and hepatocytes from LPS-treated rats. Infection and Immunity 1995; 63:2435-2442

173. Tobias PS, Ulevitch RJ. Control of lipopolysaccharide-high density lipoprotein binding by acute phase protein(s). J Immunol 1983; 131:1913-1916

174. Fearon KCH. The mechanisms and treatment of weight loss in cancer. Proc Nutr Soc 1992. $51: 251-265$

175. Fearon KCH, McMillan DC, Preston T, Hansell DT, Shenkin A, Garden OJ. Whole-body protein turnover and the acute phase response in relation to the survival of colon cances patients. Proc Nutr Soc 1991; 50:143A 


\title{
Chapter 2
}

\section{ANALYSIS OF THE ENERGY BALANCE IN LUNG CANCER PATIENTS}

\begin{abstract}
Previous studies have shown that an elevated resting energy expenditure (REE) frequently occurs in lung cancer patients. The aim of the present study was to assess the balance between REE and dietary intake and to analyse the contributing factors of elevated REE in newly detected lung cancer patients. Hundred newly detected lung cancer patients were evaluated. Measured values of REE were adjusted for the values predicted by the Harris-Benedict (HB) formula and for Fat-Free Mass (FFM) assessed by the bio-electrical impedance method.

Dietary intake was measured using a dietary history.

A substantial number of patients (30\%) had a weight loss of $10 \%$ or more from their pre-illness stable weight. An elevated REE was found in $74 \%$ of the patients. Stratification by tumor localization revealed that patients with a central tumor had a significantly higher REE $(121 \pm 13 \%$ versus $110 \pm 10 \%$ of predicted, $p<0.001)$ and significantly higher level of $\mathrm{C}$-reactive protein $(35 \pm 35 \mathrm{mng} / \mathrm{d}$ versus $16 \pm 26$ $\mathrm{mg} / \mathrm{l}, \mathrm{p}=0.006$ ) compared with patients with a peripheral tumor. Dietary intake was significantly lower in the weight losing group (1872 $\pm 542 \mathrm{kcal} /$ day versus $2169 \pm$ $782 \mathrm{kcal} /$ day, $\mathrm{p}<0.05$ ) compared with the weight stable group. We conclude that both elevated REE and decreased dietary intake contribute to weight loss in lung cancer patients. Tumor localization and inflammation were found to be contributing factors to the elevated REE.
\end{abstract}




\section{Introduction}

Weight loss is a frequently occurring problem in patients with lung cancer and is an early sign of disease. Different studies have shown that stable weight cancer patients have a better prognosis and a better response to treatment than weight losing patients $(1,2,3)$. In general, weight loss can be considered as a disturbance of the energy balance, resulting from a decreased energy intake, an increased energy expenditure or a combination of both of them. Resting energy expenditure (REE), which comprises the sleeping metabolic rate and the energy cost of arousal, can be defined as the minimum rate of energy expenditure in an awake, relaxed person, lying on a bed, after an overnight fast $(4,5)$. REE is the major determinant of total energy expenditure, amounting to about $70 \%$ in sedentary persons. Elevation of REE in lung cancer patients has been described in earlier studies (6-8), but limited information is available regarding the prevalence and determinants of the increased REE. Various factors have been suggested to influence REE, such as smoking, type of tumor, tumor stage or lung function. No data are available however regarding the balance between REE and dietary intake in a representative group of lung cancer patients.

The aim of the present study was to assess the prevalence and contributing factors of a hypermetabolic state in newly detected lung cancer patients and to assess the energy balance in order to improve our knowledge about weight loss in these patients.

\section{Materials and methods}

\section{Patients}

Hundred newly detected primary lung cancer patients were consecutively included in the study between March 1992 and May 1993. All patients had histologically documented tumors. The exclusion criteria for the study were: previous treatment with chemotherapy or radiotherapy, treatment with high doses of steroids, severe endocrine abnormalities (insulin dependent diabetes mellitus, hyper/ hypothyroidism) and body temperature exceeding $37.7^{\circ} \mathrm{C}$. Tumor stage was assessed according to the new international staging system for lung cancer. The TNM-classification was used for non-small cell lung cancer and the two-stage classification system was used for small-cell lung cancer $(9,10)$. Smoking habits of the lung cancer patients were recorded on admission. The patient population was divided into a group of non-smokers, smokers and ex-smokers defined as refraining from smoking for more than 6 months before entering the study. The study was approved by the medical ethical committee of the University hospital of Maastricht. 


\section{Resting Energy Expenditure}

REE was measured by indirect calorimetry using a ventilated hood system (Oxycon B, Mijnhardt, Bunnik, The Netherlands). After an overnight fast in hospital and while at complete rest, a measurement was made on the metabolic ward over a 20 minute period between 7 a.m. and 9 a.m. under quiet circumstances. Flow through the canopy was kept constant during measurements and was adjusted to the weight of the patient, ranging from 35 to $45 \mathrm{~L} / \mathrm{min}$. The equipment was calibrated at the start of every experiment. The precision of the device was checked monthly by burning methanol with a theoretical RQ of 0.667 during complete combustion. The REE measurement is very reproducible. Several studies have shown that the withinsubject variation in REE for healthy persons and patients with stable disease is smaller than $1,5 \%(\mathrm{p}>0.05)$ when measurements are repeated (11-13). The adjustment of REE for the metabolically active tissue mass or fat-free mass (FFM) is indicated for a correct interpretation of the variations in REE (14-16).

\section{Body composition}

Body height was measured with the subject standing barefoot and determined to the nearest $0.5 \mathrm{~cm}$. Body weight was measured with a beam scale, with the subject standing without shoes in underwear, to the nearest $0.1 \mathrm{~kg}$. Actual body weight was expressed as a percentage of ideal body weight (PIBW). Ideal body weight was determined as the midpoint of the weight range for a given height and frame size. Frame size was determined by wrist circumference (17). Mid-arm circumference was measured halfway between the coracoid process and olecranon, using a flexibie measuring tape.FFM was assessed using the single frequency bioelectrical impedance (BI) analysis (RJL-Systems, BIA-101, Detroit, M.1.). Resistance was measured with the subject in supine position on the right side, as described by Lukaski (18). FFM was calculated using a patient specific regression equation, $\mathrm{TBW}=8.9+0.5^{*}\left(\right.$ height $^{2} /$ resistance $), \mathrm{FFM}=\mathrm{TBW} / 0.73 .(19)$. The BI-method is a non-invasive. safe, rapid and reproducible technique $(20,21)$. FFM was measured in the early morning after REE-measurement to avoid influence of exercise or eating $(22,23)$. FFM was not measured in patients with signs of edema $(n=3)(24)$. Fat mass (FM) was determined by substracting FFM from body weight.

\section{Dietary intake}

Dietary intake during the period prior to admission was estimated using the diet history method (25). All interviews were performed by two trained dieticians within the first week after admission to the hospital. Dietary intake was calculated using the computer with the nutrient data base derived from the Dutch food composition tables (NEVO) (26). 


\section{Lung function parameters}

Forced expiratory volume in one second $\left(\mathrm{FEV}_{1}\right)$ and inspiratory vital capacity (IVC) were measured with a wet spirometer (Pulmonet III ${ }^{\mathrm{R}}$, Gould Godart, Bilthoven, The Netherlands); the highest value of at least three technically acceptable spirometric manoeuvres being used. The lung function variables were expressed as percentages of the reference values (27).

\section{Biochemical parameters}

Serum albumin and prealbumin, suggested to act as negative acute phase proteins (28), were assessed with the photometric method, thyroid stimulating hormone (TSH) was assessed with an immuno radiometric assay, cortisol with a radio immuno assay and C-reactive protein (CRP) by the turbidemetric method.

\section{Subdivision of patients}

Measured REE was compared to predicted REE using the Harris Benedict (HB) equations (29). Subjects with a measured REE above $110 \%$ of that predicted by the HB formula were considered hypermetabolic. This definition of hypermetabolism was based on Boothby's finding that $95 \%$ of normal individuals exhibit a measured REE within $10 \%$ of the predicted value (30). REE was expressed in absolute terms (REE), per $\mathrm{kg}$ body weight (REE/BW), per $\mathrm{kg}$ FFM (REE/FFM) and as a percentage of $\mathrm{HB}(\mathrm{REE} / \mathrm{HB})$. The percentage weight change from pre-illness stable weight reported by the patient was used to divide the patient population into a weight stable ( $<10 \%$ weight loss) and a weight losing group ( $>10 \%$ weight loss). The patient population was also divided by tumor localization: central versus peripheral. A central tumor was defined as an endoscopically visible tumor mass. The group of patients with a central tumor was further subdivided according to the radiological findings on the chest $x$-rays: group $A$ had no signs of an obstruction infiltrate, while group B had infiltrative changes with or without signs of atelectasis.

\section{Statistics}

Statistica! analyses were performed using Student's t-test when appropriate. The Mann-Whitney-U test was used for the statistical analysis of nonparametric data. Frequency data were compared using the Chi-square test. Correlations were determined using the Pearson correlation coefficient. Multiple regression was applied to analyse determining factors of the increase in REE. Results are presented as mean $\pm \mathrm{SD}$. P-values $<0.05$ were defined as statistically significant. The statistical calculations were performed by the SPSS/PC +4.0 package (31). 
Table 1: Description of the study group

\begin{tabular}{|c|c|c|}
\hline \multirow[t]{5}{*}{ Physical Characteristics } & male/female & $82 / 18$ \\
\hline & Age (year) & $65 \pm 9$ \\
\hline & Weight (kg) & $70.2 \pm 14.3$ \\
\hline & Height (cm) & $170.8 \pm 8.7$ \\
\hline & FFM $(\mathrm{kg})^{\prime}$ & $50.4 \pm 5.9$ \\
\hline \multirow[t]{3}{*}{ Lung Function } & $\operatorname{IVC}(\%)$ & $90 \pm 22$ \\
\hline & $\mathrm{FEV}_{1}(\%)$ & $76 \pm 23$ \\
\hline & & Number \\
\hline \multirow[t]{5}{*}{ Histology } & Adenocarcinoma & 21 \\
\hline & Squamous cell & 32 \\
\hline & Large cell & 27 \\
\hline & Small cell & 17 \\
\hline & Others & 3 \\
\hline \multirow[t]{5}{*}{ Tumor stage : NSCLC } & Stage I & 21 \\
\hline & Stage II & 3 \\
\hline & Stage IIIA & 19 \\
\hline & Stage IIIB & 13 \\
\hline & Stage IV & 27 \\
\hline \multirow[t]{2}{*}{ SCLC } & Limited disease & 7 \\
\hline & Extensive disease & 10 \\
\hline
\end{tabular}

Data are expressed as mean $\pm s d$. " $n=97, I V C=$ Inspiratory vital capacity, FEV $=$ Forced expiratory volume in Is.

\section{Results}

The patient characteristics of the study group are summarized in Table 1. Eightytwo men and 18 women with newly detected lung cancer were included in the study (age $65 \pm 9 y$ ). The group consisted of 17 patients with small cell lung cancer and 83 patients with non-small cell lung cancer. Tumor stage and histology are shown in Table 1. 
Table 2: Comparison of body composition and energy balance between weight-stable and weightlosing cancer patients

\begin{tabular}{|c|c|c|c|}
\hline & $\begin{array}{l}\text { Weight loss }<10 \% \\
(\mathrm{n}=70)\end{array}$ & $\begin{array}{l}\text { Weight loss } \geq 10 \% \\
(\mathrm{n}=30)\end{array}$ & P-value \\
\hline Weight loss (kg) & $1.7 \pm 3.3$ & $10.8 \pm 2.8$ & \\
\hline PIBW (kg) & $106.7 \pm 15.5$ & $97.9 \pm 14.2$ & $*$ \\
\hline FFM (kg) & $51.3 \pm 6.7$ & $48.5 \pm 6.0$ & * \\
\hline REE (kcal/day) & $1637 \pm 207$ & $1697 \pm 311$ & \\
\hline REE (\% HB) & $115 \pm 13$ & $123 \pm 12$ & * \\
\hline REE (kcal/kg BW) & $23.4 \pm 3.3$ & $25.3 \pm 2.8$ & $* *$ \\
\hline $\operatorname{REE}(\mathrm{kcal} / \mathrm{kg} \mathrm{FFM})^{\prime}$ & $32.9 \pm 4.2$ & $33.9 \pm 3.7$ & \\
\hline EI (kcal/day) & $2169 \pm 782$ & $1872 \pm 542$ & * \\
\hline EI/REE & $1.32 \pm 0.59$ & $1.16 \pm 0.34$ & \\
\hline
\end{tabular}

Data are expressed as mean $\pm s d$. p-values: ${ }^{*} p<0.05,{ }^{* *} p<0.005 .{ }^{\prime} n=97$. PIBW $=$ Percentage ideal body weight, $F F M=$ Fat free mass, $B W=$ Body weight, $E I=$ Energy intake

Data on body composition and energy balance of the weight stable and weight-losing patients are shown in Table 2. Mean reported weight loss in the weight-losing group was $10.8 \pm 2.8 \mathrm{~kg}$ over the last 6 months. In the weight-losing group REE adjustedfor $\mathrm{HB}(123$ versus $115 \% \mathrm{HB}, \mathrm{p}=0.01)$ and $\mathrm{REE}$ adjusted for $\mathrm{BW}(25.3 \pm$ 2.8 versus $23.4 \pm 3.3 \mathrm{kcal} / \mathrm{kg}, \mathrm{p}<0.005$ ) were significantly higher. This significant difference in REE disappeared after correction for FFM (33.9 versus $32.9 \mathrm{kcal} / \mathrm{kg}$ ). Dietary intake in absolute terms was significantly lower (1872 versus $2169 \mathrm{kcal} /$ day, $p<0.05$ ) in the weight-losing group.

A striking difference in tumor localization was found between the weight-losing group and the weight stable group. The weight-losing group was found to include significantly more patients with a central tumor than patients with a peripheral tumor. (26 central tumors versus 4 peripheral tumors for the weight-losing group, $p=0.009$ ). No differences in inflammatory markers, tumor stage, pulmonary function or histology were found between both groups. Thereupon, patient population was divided according to tumor localization. Patients with a central tumor had a higher REE adjusted for $\mathrm{HB}(121$ versus $110 \% \mathrm{HB}, \mathrm{p}<0.001)$ and a higher REE adjusted for FFM (33.8 versus $32.0 \mathrm{kcal} / \mathrm{FFM}, \mathrm{p}=0.015$ ) than patients with a peripheral tumor (Table 3). Patients with a central tumor lost more weight than those with a peripheral tumor (5.8 versus $1.6 \mathrm{~kg}, \mathrm{p}=0.08$ ). Dietary intake was slightly higher in patients with a central tumor (2140 versus $1952 \mathrm{kcal} /$ day), but comparable results were found when dietary intake was related to REE. 
Table 3 : Possible determinants of the energy balance for the groups with a central or peripheral numor localization

\begin{tabular}{|c|c|c|c|}
\hline Tumor localization & $\begin{array}{l}\text { Central } \\
(n=68)\end{array}$ & $\begin{array}{l}\text { Peripheral } \\
(\mathrm{n}=32)\end{array}$ & p-value \\
\hline
\end{tabular}

Body composition

Weight loss $(\mathrm{kg})$

$5.8 \pm 5.1$

$101.7 \pm 14.0$

$50.4 \pm 6.3$

$1711 \pm 295$

$121 \pm 13$

$33.8 \pm 4.5$

$2140 \pm 796$

$1.27 \pm 0.53$

$35 \pm 35$

$34.1 \pm 5.6$

$0.20 \pm 0.08$

$560 \pm 160$

$2.0 \pm 1.8$

$85 \pm 22$

$73 \pm 23$

17 pat.

51 pat.
$1.6 \pm 4.3$

$109.2 \pm 17.2$

$50.4 \pm 7.4$

$1612 \pm 250$

$110 \pm 10$

$32.0 \pm 2.7$

$1952 \pm 549$

$1.29 \pm 0.60$

$16 \pm 26$

$37.7 \pm 3.8$

$0.25 \pm 0.06$

$484 \pm 147$

$2.5 \pm 2.1$

$101 \pm 17$

$83 \pm 22$

0 pat.

32 pat.

Data are expressed as mean $\pm s d$. p-values: * $p<0.05, * * p<0.005, * * n<0.001, " n=97, P I B W$ $=$ Percentage ideal body weight, REE $=$ Resting energy expenditure, $H B=$ Harris Benedict, FFM $=$ Fat-free mass, E.I $=$ Energy intake, $C R P=C$-reactive protein, IVC $=$ Inspiratory vital capaciry, $F E V_{1}=$ Forced expiratory volume in Is, pat. = patients 


\section{Chapter 2}

Table 4: The presence of obstruction infiltrates in patients with a central tumor does not affect the energy balance, but affects CRP

\begin{tabular}{llll}
\hline & Group A & Group B & p-value \\
SCLC & $\mathrm{n}=4$ & $\mathrm{n}=13$ & \\
NSCLC & $\mathrm{n}=13$ & $\mathrm{n}=38$ & \\
\hline REE $(\mathrm{kcal} /$ day $)$ & $1790 \pm 396$ & $1682 \pm 256$ \\
REE $(\% \mathrm{HB})$ & $123 \pm 13$ & $120 \pm 14$ & \\
REE $(\mathrm{kcal} / \mathrm{ffm})^{\prime}$ & $33.7 \pm 4.7$ & $33.8 \pm 4.5$ & $* *$ \\
CRP $(\mathrm{mg} / \mathrm{l})$, & $19 \pm 20$ & $42 \pm 35$ & \\
\hline
\end{tabular}

Group $A=$ central tumor without an obstruction infiltrate, Group $B=$ central tumor with an obstruction infiltrate. Data are expressed as mean $\pm s d$. $p$-values: ${ }^{* *} p<0.005, " n=97, R E E=$ Resting energy expenditure, $F F M=$ Fat-free mass, $C R P=C$-reactive protein

Several factors suggested to contribute to an elevation of REE were investigated between both groups. Serum CRP was significantly higher in the group of patients with a central tumor ( 35 versus $16 \mathrm{mg} / \mathrm{l}, \mathrm{p}=0.006$ ). Serum albumin and prealbumin levels were significantly lower in the group of patients with a central tumor localization, while serum cortisol levels were significantly higher. TSH levels were not significantly different between both groups (Table 3). Lung function tesis showed significani differences between the two groups. IVC and FEV, were lower in the group of patients with a central tumor localization, in accordance with a more restrictive loss of lung function (Table 3). 7 Patients in the central group and 3 patients in the peripheral group were known with COPD prior to their diagnosis of lung cancer. There was no difference in smoking behavior between the groups of patients with a central or peripheral tumor localization $(p=0.36)$. Small cell lung cancer only occurred in the group of patients with a central tumor localization. Therefore the group of patients with a central tumor was further subdivided according to histology: small cell lung cancer (SCLC) versus non-small lung cancer (NSCLC). REE adjusted for FFM was significantly higher in the group of patients with SCLC $(36.4 \pm 4.1$ versus $32.9 \pm 4.4 \mathrm{kcal} / \mathrm{kgFFM}, \mathrm{p}<0.01)$. All the other metabolic parameters analysed were not signifcantly different between the groups of SCLC and NSCLC.

To evaluate the possible influence of infiltrative abnormalities of the lung, the group of patients with a central tumor localization was subdivided on the basis of radiological findings on the chest $x$-ray. REE, whether expressed in absolute terms or adjusted for HB and FFM, was not different for the two groups with or without an obstruction infiltrate (Table 4). A 2 -fold increase in CRP however was found in the group of patients with an obstruction infiltrate on the chest $x$-ray $(p<0.005)$. 
Possible determinants on the elevation of REE adjusted for HB were further analysed by multiple regression analysis (Table 5). Tumor stage, tumor histology, tumor localization, CRP, lung function and smoking behavior were chosen as possible determining factors. Tumor localization $(\mathrm{p}<0.05)$ and CRP $(\mathrm{p}<0.005)$ contributed significantly to the explained variation in REE/HB. When REE in absolute terms was considered as dependent variable and tumor localization, CRP, FFM and FM were included in the regression analysis, the tumor localization was still a significant contributor $(p<0.05)$ in addition to FFM $(p<0.001)$ and FM $(\mathrm{p}<0.001)$.

Table 5: multiple regression analysis

REE adjusted for $\mathrm{HB}$ as dependent variable:

\begin{tabular}{lcccc}
\hline Variable & B & SE B & T Sig & p-value \\
\hline Tumor stage & .039 & .040 & .334 & .739 \\
Tumor histology & -.051 & -.054 & -.456 & .650 \\
Tumor localization & -.242 & -.242 & -2.105 & .039 \\
CRP $(\mathrm{mg} / \mathrm{l})$ & .125 & .042 & 3.003 & .004 \\
FEV $(\%)$ & -.154 & -.174 & -1.488 & .141 \\
IVC $(\%)$ & -.174 & -.174 & -1.488 & .141 \\
Smoking behavior & .143 & .150 & 1.276 & .206 \\
\hline
\end{tabular}

$R^{2}=0.111, F=9.016$, Significance of $F=0.004$

REE as dependent variable:

\begin{tabular}{lcccc}
\hline Variable & B & SE B & T Sig & P-value \\
\hline FFM $(\mathrm{kg})$ & 26.800 & 2.800 & 9.570 & .000 \\
FM $(\mathrm{kg})$ & 10.917 & 2.080 & 5.249 & .000 \\
CRP $(\mathrm{mg} / \mathrm{l})$ & .717 & .591 & 1.213 & .228 \\
Tumor localization & -97.254 & 39.328 & -2.473 & .015 \\
\hline
\end{tabular}

$R^{2}=0.56, F=28.167$, Significance of $F<0.001$

$B=$ regression coefficient, $S E B=$ standard error of the regression coefficient, $\bar{T}$ Sig $=$ regression coefficient / standard error of the regression. coefficient, $R=$ correlation coefficient, $F=$ mean square of the regression analysis. / residual of the regression analysis, $C R P=C$-reactive protein, $F E V_{1}=$ Forced expiratory volume in I s., IVC = Inspiratory vital capaciry, $F F M=$ Fat free mass, $F M=$ Fat mass 


\section{Chapter 2}

\section{Discussion}

The present study clearly shows that the energy balance in newly detected lung cancer patients is disturbed in a high proportion of patients: An REE > $110 \%$ of predicted occurred in $74 \%$ of the patients. A substantial number of patients (30\%) had a weight loss of $10 \%$ or more from their pre-illness stable weight. The energy balance data indicate that both an elevated REE and a decreased dietary intake contribute to weight loss. Central tumor localization and inflammation, reflected by C-reactive protein values, were found as contributing factors to the increase in resting energy expenditure.

In general, energy expenditure data are related to prediction formulae including weight, height, age and gender. The formulae however do not take differences in body composition between individuals into account. It is generally acknowledged that in the absence of excessive fluid shifts, a useful estimate of the metabolically active tissue mass is given by FFM. Recently bioelectrical impedance was introduced as an easy and reliable measurement of FFM $(20,21)$. In an eariier study, we have validated this method in lung cancer patients by comparing the results with deuterium dilution as a reference method for the measurement of total body water (19). It appeared that measurement of resistance gave a reliable estimation of FFM in lung cancer patients. Indeed in the present study, differences were seen between metabolic data adjusted for FFM and expressed as percentage of the prediction formula.

Besides a high prevalence of hypermetabolism in our group of lung cancer patients, REE in weight losing patients tended to be higher compared to the weight stable group. This finding is in contrast with the decrease in metabolic rate which normally occurs during starvation and weight loss in healthy individuals or patients (32). The tumor related increase in REE was not balanced by an increase in dietary intake: dietary intake in absolute terms as well as dietary intake expressed as a ratio of measured resting energy expenditure were markedly lower in the weight losing group. No difference in histology or tumor stage was found between the weight losing and weight stable group.

Tumor localization was found to play a determining role in the metabolic derangements in lung cancer patients. The weight losing group consisted of far more patients with a central tumor localization than the weight stable group. Moreover, the patients with a central tumor localization had also a signifi-cantly higher REE adjusted for body weight and FFM than patients with a peripheral tumor localization. The stratifi-cation for histology in the group of patients with central tumor localization revealed that patients with SCLC had a significantly higher REE adjusted for FFM. The presence of post-obstructive infiltrative radiological changes could not explain the increase of REE. The pattern of negative and positive acute phase proteins however reflected a marked inflammatory response in patients with a centrally located tumor. The cortisol levels were also elevated in the central group. 
Possible determinants on the elevation of REE adjusted for HB were further analysed by multiple regression analysis. CRP and umor localization were found to influence REE adjusted for HB significantly. The present study did show that neither tumor stage, tumor histology, lung function nor smoking behavior were significant determinants for the elevation of REE adjusted for HB. Conflicting studies on smoking behavior and increased energy expenditure have been reported. Hofstetter et.al. reported a significant elevation of 24-h energy expenditure to be associated with smoking, but no effects on REE the morning after a day with cigarette smoking (33). Some studies reported about a decrease of REE after smoking cessa-tion $(34,35)$, while others found no effect $(36,37)$. The present study confirms previous reported findings that the increase in REE cannot be explained by tumor stage, histology, pulmonary function or smoking behaviour (7). When REE in absolute terms was considered as dependent variable and body composition in addition to tumor localization and CRP was included into the multiple regression analysis, FFM and FM were significantly related to the increase in REE next to tumor localization, which remained an independent contributor to the explained variation.

In conclusion, the present study demonstrates a disturbed energy balance in $70 \%$ of the lung cancer patients. Tumor localization and level of inflammation were found to be determining factors of the increase in resting energy expenditure. Further analysis is required to assess the interesting relationship between the localization of the lung tumor, the presence of acute-phase proteins and the concomitant metabolic disturbances. Unraveling the pathogenesis of weight loss as a constitutional effect of bronchogenic carcinoma can give insights into the metabolic response of the host to the tumor. 


\section{References}

1. De Wyss WD, Begg D, Lavin PT, et al. Prognostic effect of weight loss prior to chemotherapyin cancer patients. Am J Med 1980; 69:491-497

2. Kern KA, Norton JA. Cancer cachexia. JPEN 1988; 12:286-295

3. Van Eys J. Effect of nutritional status on response to therapy. Cancer Res (suppl.) 1982; 42 : $747 \mathrm{~s}-753 \mathrm{~s}$.

4. Ravussin E. Lillioja S, Anderson TE, Christin L, Bogardus C. Determinants of 24 hour energyexpenditure in man: methods and results using a respiration chamber. J Clin Invest 1986; 78:1568-1578

5. Ravussin E, Bogardus C. Relationship of genetics, age and physical fitness to daily energy expenditure and fuel utilization. Am J Clin Nutr 1989; 49:968-975

6. Hansell DT, Davies JWL, Burns HJG. The effects on resting energy expenditure of different tumor types. Cancer 1986; 58:1739-1744

7. Fredrix EWHM, Wouters EFM, Soeters PB, van der Aalst CJM, Kester ADM, von Meyenfeldt MF, et al. Resting energy expenditure in patients with non-small cell lung cancer. Cancer 1991; 68:1616-1621

8. Russell DMcR, Shike M, Marliss EB, Detsky AS, Shepherd FA Feld R, et al. Effects of total parenteral nutrition and chemotherapy on the metabolic derangements in small cell lung cancer. Cancer Res 1984: 44:1706-1711

9. Mountain CF. A new international staging system for lung cancer. Chest $1986 ; 89: 225 \mathrm{~s}-233 \mathrm{~s}$

10. Patel AM, Dunn WF, Trastek VF. Staging systems of lung cancer. Mayo Clin Proc 1993; 68 : 475-482

11. Murgatroyd PR, Davies HL, Prentice AM. Intra-individual variability and measurement noise in estimates of energy expenditure by whole body indirect calorimetry. $\mathrm{Br}$ J Nutr 1987; 58:347-356

12. Fredrix EWHM. Soeters PB, Von Meyenfeldt MF. Saris WHM. Measurement of resting energy expenditure in a clinical setting. Clin Nutrition 1990; 9:299-304

13. Schols AMWJ, Schoffelen P, Ceulemans H, Wouters EFM, Saris WHM. Measurement of resting energy expenditure in patients with COPD in a clinical setting. JPEN 1992; 16:364-368

14. Fredrix EWHM. Soeters PB, Rouflart MMJ, von Meyenfeldt MF, Saris WHM Resting energy expenditure in patients with newly detected gastric and colorectal cancer. Am J Clin Nutr 1991; 53:1318-1322

15. Hyltander A, Drott C, Körner U, Sandström R, Lundholm K. Elevated energy expenditure in cancer patients with solid tumours. Eur J Cancer 1991; 27:9-15

16. Hansell DT, Davies JWL. Burns HJG. The relationship between resting energy expenditure and weight loss in benign and malignant disease. Ann Surg 1986; 203:240-245

17. Metropolitan life insurance company. Desirable weights for men: desirable weights for women. New York: life extension institute of New York City, statistical bulletin, nos. 23 and 24, 1943.

18. Lukaski HC, Johnson PE, Bolonchuk WW, Lykken GI. Assessment of fat-free mass using bioelectrical impedance measurements of the human body. Am. J Clin Nutr 1985; 41:810-817

19. Fredrix EWHM, Saris WHM, Soeters PB, Kester ADM, von Meyenfeldt MF, Wouters EFM, et al. Estimation of body composition by bioelectrical impedance in cancer patients. Eur J Clin Nutrition 1990; 44:749-752

20. Chumlea WC. Baumgartner RN. Status of anthropometry and body composition data in elderly subjects. Am I Clin Nutrition 1989; 50:1158-1166.

21. Zarowitz BJ, Pilla. AM. Bioelectrical impedance in clinical practice. DICP. the Annals of Pharmacotherapy 1989: 23:548-555

22. Deurenberg P. Weststrate JA, Paymans I, van der Kooy K. Factors affecting bioelectrical impedance measurements in humans, Eur J Clin Nutrition 1988; 42:1017-1022 
23. Schols AMWJ, Dingemans ANC, Soeters PB, Wouters EFM. Within day variation of bioelectrical resistance measurements in patients with chronic obstructive pulmonary disease. Clin Nutrition 1990; 9:266-271

24. Piccoli A, Rossi B, Pillon L. Is $50 \mathrm{kHz}$ the optimal frequency in routine estimation of body water by bio-electrical impedance analysis? Am J Clin Nutr 1992; 56: 1069-1070

25. Cameron ME, van Staveren WA. Manual on methodology for food consumption studies, Oxford University Press 1988.

26. NEVO Tabel. Stichting Nederlands voedingsstoffenbestand. 's Gravenhage: Voorlichtingsbureau voor de voeding, 1990.

27. Quanjer PH. Standardized lung function testing. Bulletin Europ Physiopath Resp 1983; 19:7-44

28. Langstein H, Norton J. Mechanisms of cancer cachexia. Nutrition and Cancer 1991; 5:103-123

29. Harris JA, Benedict FG. A biometric study of basal metabolism in man. Washington DC: Carnegie Institute of Washington; 1919, Publication 279.

30. Boothby WM, Berkson J, Dunn HL. Studies on the energy of metabolism of normal individuals: a standard for basal metabolism with a nomogram for clinical application. Am I Physiology 1936; 3: 468-483

31. SPSS/PC+ Statistics 4.0 for the IBM.PC/XT/AT and PS/2, M.J. Norusis /SPSS Inc, New York 1990.

32. Brennan MF. Uncomplicated starvation versus cancer cachexia. Cancer 1977; 37:2359-2364

33. Hofstetter A, Schutz Y. Jéquier E, Wahren J. Increased 24-hour energy expenditure in cigarette smokers. N Engl J Med 1986; 314:79-82

34. Moffatt RJ, Owens SG. Cessation from smoking: changes in body weight, body composition, resting metabolism and energy consumption. Metabolism 1991; 40:465-470

35. Dallosso HM, James WPT. The role of smoking in the regulation of energy balance. Int $\mathbf{J}$ obes I $984 ; 8: 365-375$

36. Stamford BA, Matter S, Fell RD, Papanek P. Effects of smoking cessation on weight gain, metabolic rate, caloric consumption, and blood lipids. Am J Clin Nutr 1986; 43:486-494

37. Burse RL. Bynum GD, Pandolf KB, Goldman RF, Sims EAH, Danforth ER. Increased appetite and unchanged metabolism upon cessation of smoking with diet held constant. Physiologist $1975 ; 18: 157$ 



\title{
HYPERMETABOLISM IS MORE PRONOUNCED IN SMALL CELL LUNG CARCINOMA COMPARED TO NON-SMALL CELL LUNG CARCINOMA AND HEALTHY CONTROLS
}

\begin{abstract}
Weight loss is a frequently occurring problem in lung cancer patients. Both an increased resting energy expenditure (REE) and a decreased energy intake contribute to weight loss in lung cancer patients. The central localization of the tumour and enhanced systemic levels of inflammatory mediators were found to be contributing factors to the elevated REE in a previous study. The aim of the present study was to evaluate the metabolic and inflammatory characteristics of small cell lung carcinoma (SCLC) patients and non-small cell lung carcinoma (NSCLC) patients. The metabolic parameters of the lung cancer patients were compared to a healthy control group. REE was measured in 66 patients with lung cancer subdivided according to histology and in 33 healthy controls, matched for sex, age and fat free mass (FFM). Inflammatory mediators were measured in plasma of the lung cancer patients.

An increased REE adjusted for FFM was found in the lung cancer patients. Patients with SCLC had an increased REE adjusted for FFM (1925 $\pm 238 \mathrm{kcal} /$ day) compared to patients with NSCLC $(1789 \pm 162 \mathrm{kcal} /$ day, $p<0.01)$. FFM explained $69 \%$ and $48 \%$ of the interindividual variation in REE in controls and NSCLC respectively, while FFM explained only $25 \%$ of the variation in REE in SCLC. In SCLC, also fat mass (FM) contributed significantly with $28 \%$ to the explained variation in REE. Increased concentrations of soluble TNF-receptor 75 (sTNF-R75) and cortisol were found in SCLC compared to NSCLC. Cortisol levels were within the normal range. LPS-binding protein (LBP) and STNF-R55 were significantly related to plasma cortisol.

In conclusion, an enhanced REE adjusted for FFM occurred in SCLC compared to NSCLC. These data cannot be explained by differences in inflammatory mechanisms.
\end{abstract}




\section{Introduction}

Weight loss is a frequently occurring problem in patients with lung cancer (1-3). Weight loss can be considered as a disturbance of the balance between energy intake and energy expenditure. In a former study we have demonstrated that both an increased resting energy expenditure (REE) and a decreased energy intake relative to energy expenditure contribute to weight loss in lung cancer patients (4). The central localization of the tumor and enhanced systemic concentrations of inflammatory mediators were found to be contributing factors to the elevated REE (4).

Lung cancer can be subdivided into two groups according to histology: small cell lung carcinoma (SCLC) and non-small cell lung carcinoma (NSCLC). SCLC belongs to the group of neuroendocrine tumors (5). The presence of neurosecretory granules and the ability to secrete a variety of polypeptide hormones are characteristics of the SCLC cells. SCLC is the most aggressive tumor among the different types of lung cancer. Hypermetabolism has been described in patients with SCLC $(6,7)$ and patients with NSCLC as well $(8,9)$.

Tumor-induced hypermetabolism may be caused by a direct effect of the tumor itself, but can also be the consequence of secretion of hormones or cytokines. Cytokines are involved in metabolic derangements as has been demonstrated in experimental animal studies (10-18). In a previous study we described a relationship between the presence of a systemic inflammatory response with weight loss and hypermetabolism in NSCLC patients (19). The systemic inflammatory response was assessed by measurement of both soluble (s) TNF-receptors and the acute phase proteins C-Reactive Protein (CRP) and LPS-Binding Protein (LBP). STNF-receptors are considered to be the natural inhibitors of $\mathrm{TNF}^{-} \alpha$ and enhanced concentrations of the sTNF-receptors in plasma reflect a systemic inflammatory response $(20,21)$.

Since SCLC and NSCLC have different characteristics, we hypothesized that the determinants of the enhanced REE, specifically the influence of inflammatory mediators, might be different for both groups. Therefore the aim of the present study was to evaluate the metabolic and inflammatory characteristics of SCLC and NSCLC patients. In addition, metabolic parameters of the lung cancer population were compared to a healthy control group.

\section{Subjects and methods}

\section{Patients and healthy controls}

33 SCLC patients, 33 NSCLC patients and 33 healthy controls were included in the study. The three groups were matched for sex, age and fat free mass (FFM). All patients had histologically documented tumors and had not yet received treatment. 
The exclusion criteria for the study were: previous treatment with chemotherapy or radiotherapy, treatment with high doses of corticosteroids, severe endocrine abnormalities (insulin dependent diabetes mellitus, hyper/hypothyroidism) and body temperature exceeding $37.7{ }^{\circ} \mathrm{C}$. Tumor stage was assessed according to the international staging system for lung cancer. The TNM-classification was used for non-small cell lung cancer and the two-stage classification system was used for small-cell lung cancer $(22,23)$. Healthy controls had a stable weight for more than one year, a Body Mass Index (BMI) $<30 \mathrm{~kg} / \mathrm{m}^{2}$, a normal body temperature, and no evidence of physical or mental disease as assessed by physical examination. The study was approved by the medical ethical committee of the university hospital of Maastricht. Informed consent was obtained from all patients and controls.

\section{Resting energy expenditure}

REE was measured by indirect calorimetry using a ventilated hood system (Oxycon B*, Mijnhardt, Bunnik, The Netherlands). Flow through the canopy was kept constant during measurements and was adjusted to the weight of the patient, ranging from 35 to $45 \mathrm{~L} / \mathrm{min}$. The equipment was calibrated at the start of every experiment. The precision of the device was checked monthly by burning methanol with a theoretical RQ of 0.667 after complete combustion. After an overnight fast in the hospital and while at complete rest, a measurement was made on the metabolic ward over a 20 minute period between $7 \mathrm{a} . \mathrm{m}$. and $9 \mathrm{a} . \mathrm{m}$. under quiet circumstances. Measurements in control subjects were performed similarly but on an outpatient basis. Fredrix et al. (24) showed that variations due to limited physical activities, including a short travel from home to the hospital, do not significantly influence the measurement of REE.

\section{Body composition}

Body height was measured with the subject standing barefoot and determined to the nearest $0.5 \mathrm{~cm}$. Body weight. was measured with a beam scale (SECA, Germany), with the subject standing without shoes in underwear, to the nearest $0.1 \mathrm{~kg}$. The adjustment of REE for the metabolically active tissue mass or FFM is indicated for a correct interpretation of the variations in REE (25-27). FFM was assessed using the single frequency bioelectrical impedance (BI) analysis (RJL-Systems, BIA-101, Detroit, M.I.). Resistance was measured with the subject in supine position on the right side, as described by Lukaski (28). FFM was measured in the early morning after REE-measurement to avoid influence of exercise or eating $(29,30)$. The BImethod is a non-invasive, safe, rapid and reproducible measurement of body composition $(31,32)$. In an earlier study we established a good correlation between height ${ }^{2} /$ resistance and total body water (TBW), as assessed by deuterium dilution in elderly cancer patients (33). Based on this study the following patient specific 


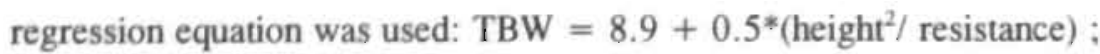

$\mathrm{FFM}=\mathrm{TBW} / 0.73$ (33). Fat mass (FM) was calculated as body weight minus FFM.

\section{Plasma samples}

Blood was obtained by venepuncture from patients before breakfast. Blood was collected in evacuated blood collection tubes (Sherwood Medical, St. Louis, MO) containing 50 IU Heparin (Leo Pharmaceutical Products B.V., Weesp, The Netherlands). Plasma was separated from blood cells by centrifugation at $1000 \mathrm{G}$ for 5 minutes within 1 hour after collection. Plasma samples were stored at $-70^{\circ} \mathrm{C}$ until analysis.

\section{Measurement of inflammatory mediators}

Inflammatory mediators were measured using sandwich ELISA as described elsewhere (34-36). In short, for measurement of sTNF-R55 and sTNF-R75, MAbs MRI-1 and MR2-2 were used respectively for coating. Specific biotin labelled polyclonal rabbit anti-sTNF-R IgG were used as detector reagents. The standards used were recombinant human sTNF-R55 and sTNF-R75. The detection limit of both assays was $100 \mathrm{pg} / \mathrm{ml}$. Polyclonal rabbit anti-human recombinant $\mathrm{LBP} \operatorname{lgG}$ was used as coating for the LBP ELISA and biotin labelled polyclonal rabbit anti-human recombinant LBP $\operatorname{lgG}$ was used for detection of $\mathrm{LBP}$. The standard used was recombinant human LBP. Washing and dilution was performed in buffer containing $40 \mathrm{mM} \mathrm{MgCl}$ for preventing disturbance by LPS of LBP recovery in the ELISA. The detection limit of the assay was $200 \mathrm{pg} / \mathrm{ml}$. The TNF- $\alpha$ ELISA consisted of $61 \mathrm{E} 71$ as coating Mab and polyclonal rabbit anti-human TNF- $\alpha$ Abs. TNF- $\alpha$ could be detected with a lower detection limit of $20 \mathrm{pg} / \mathrm{ml}$. The standard used was recombinant human TNF- $\alpha$. Immuno assay plates (Nunc-Immuno Plate Maxisorp, Roskilde, Denmark) were used for the ELISA assays. Biotinylated samples were detected with streptavidin-peroxidase conjugate (Dako, Glostrup, Denmark), while peroxidase-conjugated goat anti-rabbit IgG (Jackson Immunoresearch, West Grove, PA) was used in the TNF- $\alpha$ ELISA. TMB $\left(3,3^{\prime}, 5,5^{\prime}\right.$-tetramethylbenzidine, Kirkegaard \& Perry Lab., Gaithersburg, MD) was used as a substrate. Photospectometry $(450 \mathrm{~nm})$ was performed using a micro ELISA auto-reader. CRP was measured by turbidimetry. The detection limit of the assay was $5 \mu \mathrm{g} / \mathrm{ml}$.

\section{Biochemical parameters}

In order to exclude hyper/hypothyroidism, TSH was assessed with an immunoradiometric assay. Cortisol was determined in order to evaluate adrenal function and possible ectopic cortisol production as observed in SCLC (37-39). Cortisol was 
measured with a radioimmunoassay. Plasma creatinine was used as a renal function parameter and detected by the modificated Jassé-reaction (Dimension, Dupont, France) (40).

\section{Pulmonary function}

An elevated REE has been described in patients with disturbed lung function such as COPD $(41,42)$. Also in lung cancer patients, pulmonary function can be reduced because of the presence of the tumor or preexisting pulmonary dysfunction. Therefore Forced Expiratory Volume in 1 sec $\left(\mathrm{FEV}_{1}\right)$ and inspiratory Vital Capacity (IVC) were determined. Both FEV 1 and IVC were measured with a wet spirometer (Pulmonet III"; Gould Godart, Bilthoven, the Netherlands); the highest value of at least three technically acceptable spirometric manoeuvres being used. The lung function variables were expressed as percentages of the reference value (43).

\section{Statistics}

Weight loss was calculated as the difference between reported preillness stable weight minus actual weight. The control group had been weight stable for more than $1 \mathrm{y}$ before measurement. REE was expressed in absolute terms (REE) and adjusted for FFMl according to Ravussin (44). The adjusted REE was calculated as the group mean REE plus measured REE minus predicted REE. The group REE is the mean absolute $\operatorname{REE}(n=99)$, the measured REE is the resting metabolic rate in each subject, and the predicted REE is the calculated energy expenditure obtained by using the individual FFM in the linear regression equation of REE on FFM generated in the control group. Measured REE was also compared to predicted REE using the Harris Benedict (HB) equations (45) in order to allow comparison between this study and previous studies on REE in cancer patients. Subjects with a measured REE above $110 \%$ of that predicted by the HB formula were arbitrarily considered hypermetabolic.

Statistical analyses were performed using Student's $t$ test when appropriate. The Mann-Whitney $U$ test was used for the statistical analysis of nonparametric data.

Since impaired renal clearance leads to increased sTNF-receptor concentrations $(46,47)$, the plasma concentrations of sTNF-R55 and sTNF-R75 were analyzed together with serum creatinine. Therefore an analysis of covariance was performed, using plasma creatinine as covariable, and considering STNF-R55 and STNF-R75 as factors in the statistical model. Frequency data were compared using the chi-square test. Correlations were determined using the Pearson correlation coefficient. Results are presented as mean \pm standard deviation (SD). P-values $<0.05$ were defined as statistically significant. The statistical calculations were performed by the SPSS/PC +4.0 package (48). 
Chapter 3

Table I: Description of the study population

\begin{tabular}{|c|c|c|c|}
\hline & $\begin{array}{l}\text { SCLC } \\
(\mathrm{n}=33)\end{array}$ & $\begin{array}{l}\text { NSCLC } \\
(\mathrm{n}=33)\end{array}$ & $\begin{array}{l}\text { Controls } \\
(\mathrm{n}=33)\end{array}$ \\
\hline male/female & $24 / 9$ & $24 / 9$ & $24 / 9$ \\
\hline age $(y)$ & $63 \pm 10$ & $65 i \pm 8$ & $66 \pm 8$ \\
\hline FFM (kg) & $48.6 \pm 6.0$ & $48.7 \pm 5.9$ & $5.1 .0 \pm 7.1$ \\
\hline $\mathrm{FM}(\mathrm{kg})$ & $21.1 \pm 8.4$ & $20.3 \pm 7.8$ & $22.7 \pm 7.5$ \\
\hline weight loss $>10 \%$ (n) & 10 & 11 & 0 \\
\hline BMI $\left(\mathrm{kg} / \mathrm{m}^{2}\right)$ & $24.4 \pm 3.2$ & $23.8 \pm 3.6^{\circ}$ & $25.4 \pm 3.2$ \\
\hline weight loss (\%) & $6.2 \pm 6.0$ & $5.0 \pm 7.1$ & $0 . \pm 0$ \\
\hline $\mathrm{TSH}(\mathrm{mU} / \mathrm{I})$ & $3.3 \pm 3.6$ & $2.6 \pm 2.3$ & N.T. \\
\hline Cortisol (nmol/l) & $569 \pm 179^{\prime}$ & $470 \pm 170$ & N.T. \\
\hline $\operatorname{IVC}(\%)$ & $86.6 \pm 23.4$ & $93.2 \pm 18.8$ & N.T. \\
\hline $\mathrm{FEV}_{1}(\%)$ & $76.3 \pm 24.8$ & $75.3 \pm 23.2$ & N.T. \\
\hline $\begin{array}{l}\text { Tumor stage (NSCLC) } \\
\text { stage I and II (n) }\end{array}$ & & 13 & \\
\hline stage IIIA & & 4 & \\
\hline stage IIIB & & 5 & \\
\hline stage IV & & 11 & \\
\hline \multicolumn{4}{|l|}{ Tumor stage (SCLC) } \\
\hline limited & 10 & & \\
\hline extensive & 23 & & \\
\hline
\end{tabular}

Data are expressed as mean $\pm s d$. $p$-values: "NSCLC. versus controls, $p<0.05$. 'SCLC versus NSCLC, $p<0.05, N T=$ not tested, $S C L C=$ small cell lung carcinoma, $N S C L C=$ non-small cell lung cancer, $F F M=$ far free mass; $F M=$ fat mass; $n=$ number of subjects; $B M I=$ body mass index; $T S H=$ thyroid stimulating hormone; $I V C=$ inspiratory vital capacity; $F E V=$ forced expiratory volume in $/ \mathrm{s}$.

\section{Results}

The characteristics of the study population are summarized in Table 1. Each group consisted of 24 men and 9 women. No differences were found in body weight among the 3 groups, but BMI was significantly lower in the NSCLC group compared to the healthy controls $(p<0.05)$. Part of the patients with SCLC $(n=10)$. 
Table 2: Comparison of the metabolic parameters berween the different groups

\begin{tabular}{lllll}
\hline & \multicolumn{3}{c}{ Patients } & Controls \\
\cline { 2 - 5 } & $\begin{array}{l}\text { Total group } \\
(\mathrm{n}=66)\end{array}$ & $\begin{array}{l}\text { SCLC } \\
(\mathrm{n}=33)\end{array}$ & $\begin{array}{l}\text { NSCLC } \\
(\mathrm{n}=33)\end{array}$ & $\begin{array}{l}\text { Controls } \\
(\mathrm{n}=33)\end{array}$ \\
\hline REE (kcal/day) & $1691 \pm 255^{\circ}$ & $1758 \pm 270^{\circ *}$ & $1624 \pm 224$ & $1546 \pm 248$ \\
$\begin{array}{l}\text { Adjusted REE } \\
\text { (kcal/day) }\end{array}$ & $1857 \pm 213^{* *}$ & $1925 \pm 238^{\text {eat }}$ & $1789 \pm 162^{*}$ & $1643 \pm 138$ \\
REE (\%HB) & $120 \pm 14^{* *}$ & $124 \pm 14^{\text {ent }}$ & $116 \pm 14$ & $105 \pm 9$ \\
\hline
\end{tabular}

Data are expressed as mean \pm sd, p-values: total group versus controls " $p<0.01, " p<0.001$; SCLC versus NSCLC ${ }^{*} p<0.05$, te $p<0.01 ; S C L C$ versus controls" $p<0.005, " p<0.001 ;$ NSCLC versus controls ${ }^{4} p<0.001: R E E=$ resting energy expeniture; $H B=$ Harris Benedict

and NSCLC $(n=11)$ presented with more than $10 \%$ weight loss of their preillness weight. No significant differences in lung function parameters were found between SCLC and NSCLC patients. Cortisol concentrations were significantly enhanced in SCLC patients compared to NSCLC patients (Table 1), although the mean concentration of cortisol was within the normal range (200-700 nmol/l).

Data on REE are shown in Table 2. REE adjusted for FFM was significantly higher in lung cancer patients compared to healthy controls $(p<0.001)$. Fifty-two of the 66 lung cancer patients were hypermetabolic when compared to the prediction equations of Harris Benedict versus 8 of the 33 healthy controls $(p<0.001)$. When the lung cancer population was divided according to tumor type, REE adjusted for FFM was significantly higher in SCLC patients than in NSCLC patients $(\mathrm{p}<0.01)$.

FFM explained $69 \% \quad(p<0.001)$ and $F M$ explained $7 \% \quad(p<0.01)$ of the interindividual variation in REE in the healthy control group. In the NSCLC population, FFM explained $48 \%(p<0.001)$ and FM explained $3 \%(p>0.05)$ of the interindividual variation in REE. However, in the SCLC population the prediction of REE by body composition showed a different pattern; FFM explained only $25 \%$ $(p=0.0 !)$ of the interindividual variation in REE, while FM explained $28 \%$ $(p<0.001)$. The relationship between REE and FFM as well as REE and FM is shown in scatterplots in Figure 1 for the three groups. Analysis of covariance taking FFM and FM as covariates, revealed that in the comparison between NSCLC and control subjects only FFM was a significant determinant, whereas in the comparison between SCLC and NSCLC, FFM $(p<0.001)$ and FFM(P $=0.03)$, were significant independent determinants.

To investigate the influence of tumor stage within SCLC, patients were divided into a population with limited disease $(n=10)$ and a population with extensive disease 
Chapter 3

SCLC

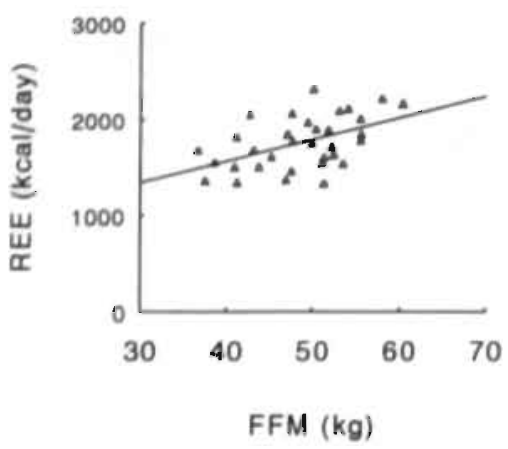

NSCLC

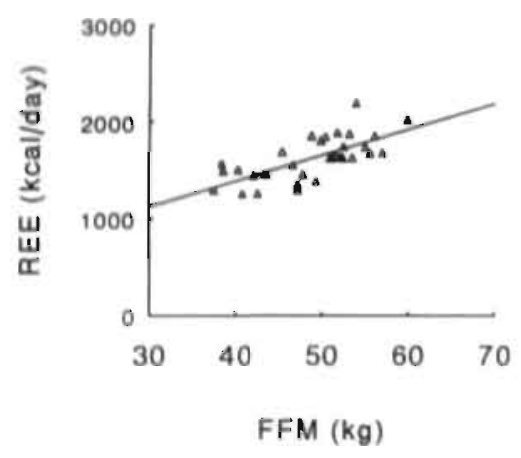

Controls

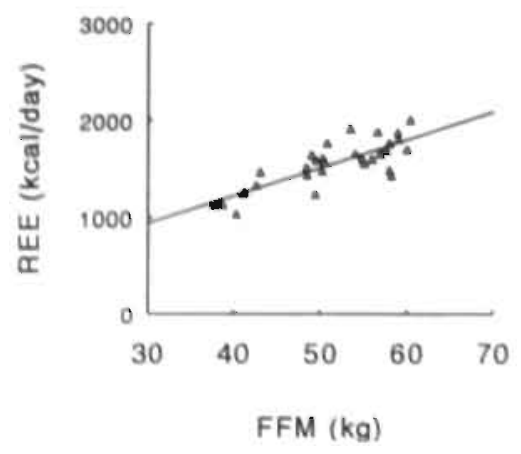

SCLC

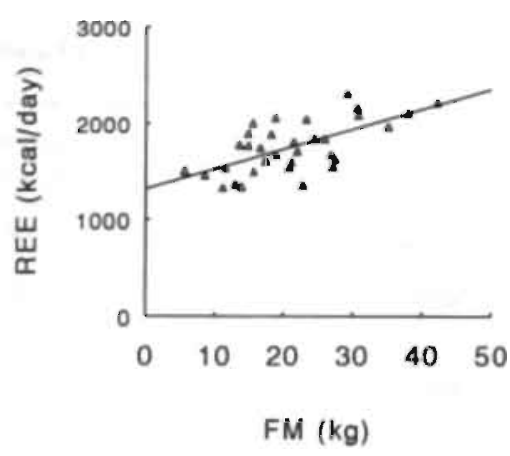

NSCLC

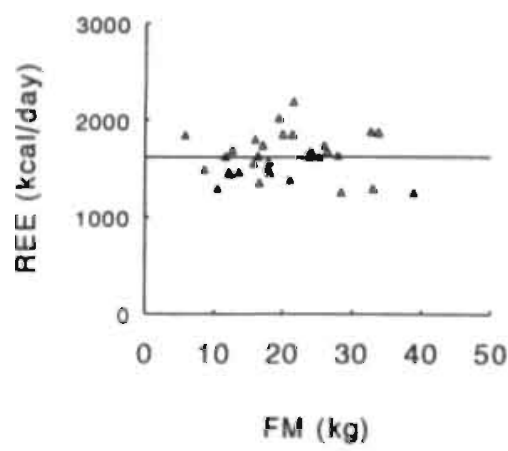

Controls

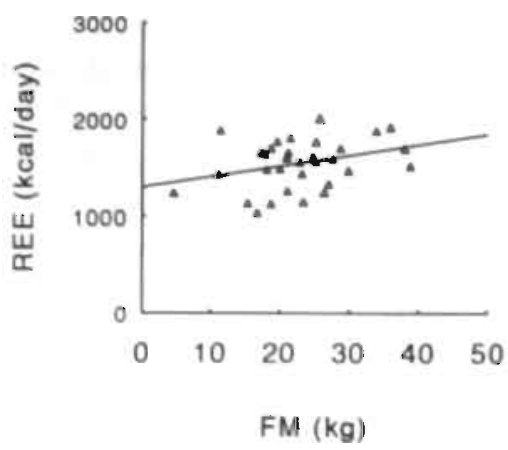

Figure 1: Scatterplots of the relationship between REE and FFM and FM for the 3 different groups 
Table 3: Metabolic parameters in small cell lung carcinoma patients divided according to numor stage

\begin{tabular}{llll}
\hline & $\begin{array}{l}\text { limited dis. } \\
(\mathrm{n}=10)\end{array}$ & $\begin{array}{l}\text { extensive dis. } \\
(\mathrm{n}=23)\end{array}$ & p-value \\
\hline Male/female & $5 / 5$ & $19 / 4$ & 0.05 \\
Weight loss $(\mathrm{kg})$ & $4.7 \pm 4.7$ & $4.8 \pm 4.7$ & N.S. \\
FFM (kg) & $45.7 \pm 7.2$ & $49.8 \pm 5.1$ & N.S. \\
FM (kg) & $21.0 \pm 10.4$ & $21.1 \pm 7.7$ & N.S. \\
BMI $\left(\mathrm{kg} / \mathrm{m}^{2}\right)$ & $23.2 \pm 3.7$ & $25.0 \pm 3.0$ & N.S. \\
REE (kcal/day) & $1670 \pm 247$ & $1796 \pm 277$ & N.S. \\
Adjusted REE (kcal/day) & $1920 \pm 206$ & $1927 \pm 255$ & N.S. \\
\hline
\end{tabular}

Data are expressed as mean $\pm s d ; N . S=$ nor significant; limired dis. = limited disease; extensive dis. = extensive disease; $F F M=$ fat free mass: $F M=$ fat mass; $B M I=$ Body Mass Index; $R E E=$ resting energy expenditure.

$(n=23)$ (Table 3). There were significantly more women in the population with limited disease compared to the population with extensive disease $(p<0.05)$, but no differences were found in metabolic parameters between both populations. In addition multiple regression was applied in order to analyse the influence of sex on tumor stage and metabolic parameters, but no significant influence could be demonstrated.

The influence of the presence of systemic inflammation on the metabolic derangements was investigated by measuring inflammatory mediators in peripheral blood of the lung cancer patients (Table 4). We were not able to measure inflammatory mediators in plasma of the present control group. In a previous study however, control samples were obtained from 26 healthy, elderly individuals (19). The mean values $( \pm \mathrm{sd})$ of the inflammatory mediators in plasma of healthy controls were as follows: sTNF-R55 $1.0 \pm 0.3 \mathrm{ng} / \mathrm{ml}$; sTNF-R75 $1.1 \pm 0.4 \mathrm{ng} / \mathrm{ml}$; LBP 8.6 $\pm 3.1 \mu \mathrm{g} / \mathrm{ml}$ and $\mathrm{CRP}<5 \mu \mathrm{g} / \mathrm{ml}$. TNF- $\alpha$ was not detectable in plasma of healthy individuals and lung cancer patients. STNF-R75 was significantly elevated in the SCLC population compared to the NSCLC population, but no difference was found for sTNF-R55 (Table 4). Both acute phase proteins LBP and CRP' were equally elevated in the SCLC and NSCLC population in comparison to healthy controls. STNF-R55 and LBP were significantly related with cortisol $(r=0.42, p<0.01)$ and $(r=0.52, p<0.001)$ respectively. No significant correlation was found for sTNF$\mathrm{R} 75(\mathrm{r}=0.20)$ and CRP $(\mathrm{r}=0.33)$. 
Table 4: Inflammatory mediators in plasma of both small cell lung carcinoma patients and non-small cell lung carcinoma patients

\begin{tabular}{lccc}
\hline & SCLC $(\mathrm{n}=23)$ & NSCLC $(\mathrm{n}=23)$ & p-value \\
\hline sTNF-R55 $(\mathrm{ng} / \mathrm{ml})^{*}$ & $1.6 \pm 0.9$ & $1.2 \pm 0.7$ & \\
& 1.4 & 1.0 & $<0.05$ \\
sTNF-R75 $(\mathrm{ng} / \mathrm{ml})^{*}$ & $2.3 \pm 1.3$ & $1.6 \pm 0.4$ & \\
& 2.0 & 1.5 & \\
LBP $(\mu \mathrm{g} / \mathrm{ml})$ & $18.9 \pm 8.0$ & $17.4 \pm 12.1$ & 15.1 \\
& 18.1 & $34 \pm 36$ & 13 \\
CRP $(\mu \mathrm{g} / \mathrm{ml})$ & $34 \pm 36$ & 17 &
\end{tabular}

Data are expressed as mean \pm sd and median; " Analysis of covariance adjusted for plasma creatinine; $s T N F-R 55=$ soluble $T N F$-receptor $55 ; L B P=L P S$ binding protein; $C R P=C$-reactive protein

\section{Discussion}

The aim of the present study was to compare the metabolic and inflammatory characteristics of lung cancer patients, subdivided according to tumor type. An enhanced REE adjusted for FFM was found in SCLC patients compared to NSCLC patients, matched for sex, age and FFM. In addition, lung cancer patients had an elevated REE adjusted for FFM compared to healthy controls who were matched for sex, age and FFM as well.

An increased REE compared to predicted has been reported in lung cancer patients before (4,6-9). In addition to body composition, both tumor localization and elevated concentrations of systemic inflammatory mediators were contributing factors to the variation of REE as assessed in former studies $(4,19)$. Lung function, smoking behaviour and iumor stage on the other hand did not significantly influence the variation in REE (4). Although total energy expenditure is the sum of REE, diet induced thermogenesis, and activity related energy consumption, most studies have focussed on REE measurements.

Uniil now, only few authors have paid attention to the occurrence of hypermetabolism in SCLC $(6,7)$. Jebb et al. (7) recently demonstrated an enhanced REE adjusted for FFM in SCLC but they did not investigate possible determinants of the enhanced REE. In the present study, SCLC patients had an increased REE adjusted for FFM compared to NSCLC patients and healthy controls. Subdivision of SCLC according to tumor stage revealed that tumor stage did not influence metabolic parameters in SCLC as confirmed by Russel et al. (6). To investigate the clinical relevance of the observed elevation of REE in the pathogenesis of weight 
loss in lung cancer, the expected weight loss over 6 month period time was calculated. A recently developed computer simulation model was used (49) calculating the expected weight change in a male subject, aged $65 \mathrm{y}$, height $170 \mathrm{~cm}$ and weight $65 \mathrm{~kg}$ with REE amounting to $113 \%$ of predicted. It was found that this degree of REE elevation would result in $7 \%$ weight loss, which corresponds remarkably well with the results of the present study.

In order to explain the differences in REE, contributing factors of REE were investigated. First, the influence of body composition on REE was analyzed. FFM explained $69 \%$ and $48 \%$ of the interindividual variation in REE in controls and NSCLC respectively, while FFM explained only $25 \%$ of the variation in REE in SCLC. FM, however, explained $28 \%$ of the variation in REE in SCLC and was a significant covariate in the significant difference in REE observed between NSCLC and SCLC. These findings could indicate changes in carbohydrate cq fat metabolism specifically related to SCLC. Further, the influence of systemic concentrations of inflammatory mediators on REE was investigated. TNF- $\alpha$, Interieukin (IL) -1 and IL-6 were detected in animal models with cachexia (10-18). Biologically active TNF- $\alpha$ is difficult to detect because of its short half-time and the formation of complexes with the sTNF-receptors $(36,50)$. Therefore both sTNF-receptors were investigated in plasma. Both STNF-receptors appeared to be elevated in NSCLC patients (19). In the present study, the systemic concentrations of STNF-R75 were enhanced in SCLC compared to NSCLC, while no differences for sTNF-R55 concentrations could be demonstrated. In addition to the sTNF-receptors, we determined the acute phase proteins LBP and CRP. An enhanced acute phase response, manifested by significant elevated concentrations of CRP and LBP, was described in a previous study (19). In the present study, no differences between SCLC and NSCLC could be detected but the acute phase proteins were enhanced in both groups. An enhanced acute phase response also occurred in other groups of cancer patients $(51,52)$ which suggests that the presence of the tumor probably induces a general inflanmatory response irrespective of tumor type. Another explanation for the small differences of inflammatory mediators, might be the enhanced concentration of cortisol in SCLC compared to NSCLC. Cortisol concentrations rise during periods of stress and inflammation and can attenuate the inflammatory response $(53,54)$. Enhanced concentrations of inflammatory mediators in SCLC could therefore be reduced by cortisol. Evidence for this relationship could be derived from the significant correlation between plasma cortisol concentrations and sTNF-R55 and LBP in the present study.

In conclusion, an elevated REE adjusted for FFM occurred in SCLC patients compared to NSCLC patients. Tumor stage did not influence the metabolic parameters in SCLC. The inflammatory mediators were enhanced in both SCLC and NSCLC patients compared to healthy controls. These data suggest that the metabolic disturbances in both SCLC and NSCLC are influenced by similar inflammatory mechanisms. 


\section{References}

I De Wyss WD, Begg D, Lavin PT. Prognostic effect of weight loss prior to chemotherapy in cancer patients. Am J Med 1980; 69: 491-497

2 Kern KA, Norton JA. Cancer cachexia. JPEN 1988; 12:286-295

3 Van Eys J. Effect of nutritional status on response to therapy. Cancer Res (Suppl) 1982; 42: $747 \mathrm{~s}-753 \mathrm{~s}$

4 Staal-van den Brekel AJ, Schols AMWJ, ten Velde GPM, Buurman WA, Wouters EFM. Analysis of the energy balance in lung cancer patients. Cancer Res 1994; 54:6430-6434

5 Robbins SL, Cotran RS, Kumar VK. Pathologic basis of disease 3rd ed., Edited by Saunders. WB. Philadelphia, 1984: 749-757

6 Russell DMcR, Shike M, Marliss EB, Detsky AS, Shepherd FA, Feld R et al. Effects of total parenteral nutrition and chemotherapy on the metabolic derangements in small cell lung cancer. Cancer Res 1984; 44:1706-1711

7 Jebb SA, Osbrone RJ. Dixon AK, Bleehen NM, Elia M. Measurements of resting energy expenditure and body composition before and after treatment of small cell lung cancer. Ann Oncol 1994; 5:915-919

8 Hansell DT, Davies JW, Burns HJG. The effects on resting energy expenditure of different tumor types. Cancer 1986; 58: 1739-1744

9 Fredrix EWHM, Wouters EFM, Soeters PB, van der Aalst ACJM, Kester ADM, von Meyenfeldt MF et al. Resting energy expenditure in patients with non-small cell lung cancer. Cancer 1991; 68:1616-1621

10 Tracey KJ, Wei H, Manogue KR, Fong Y. Hesse DG, Nguyen HT et. al. Cachectin/Tumor necrosis factor induces cachexia, anemia, and inflammation. J Exp Med 1988; 167:1211-1227

11 Fong Y, Moldawer, Marano M, Wei H. Barber A, Manogue KR et al. Cachectin/TNF or IL-I $\alpha$ induces cachexia with redistibution of body proteins. Am J Physiol 1989: 25:R659-R665.

12 Smith BK. Kluger MJ. Anti-TNF- $\alpha$ antibodies normalized body temperature and enhanced food intake in tumor bearing rats. Am J Physiol 1993; 265:r651-r619

13 Costelli P. Carbo N. Tessitore L, Bagby G, Lopez-Soriano FJ, Bacino FM. Tumor Necrosis Factor- $\alpha$ mediates changes in tissue protein turnover in a rat cancer cachexia model. J Clin Invest 1993; 92:2783-2789

14 Warren RS, Starnes HF, Gabrilove JL, Oettgeb HF, Brennan MF. The acute metabolic effects of tumor necrosis factor administration in humans. Arch Surg 1987; 122:1396-1400

15 Gelin J. Moldawer LL, Lönnroth C. Sherry B, Chizzonite R, Lundholm K. Role of endogenous tumor necrosis factor $\alpha$ and Interleukin ! for experimental tumor growth and the development of cancer cachexia. Cancer Res 1991: 51:415-421

16 Sirassman G, Fong M, Kenney JS, Jacob CO. Evidence for the involvement of Interleukin 6 in experimental cancer cachexia. J Clin Invest 1992: 89:1681-1684

17 Strassman G, Jacob CO, Evans R, Beall D, Fong M, Mechanisms of experimental cancer cachexia, interaction between mononuclear phagocytes and colon-26 carcinoma and its relevance to IL-6 mediated cancer cachexia. J Immunol 1992; 148:3674-3678

18 Strassmann G, Fong M, Freter CE, Windsor S, D'Allessandro F, Nordan RP. Suramin interferes with Interleukin-6 receptor binding in vitro and inhibits colon-26-mediated experimental cancer cachexia in vivo. J Clin Invest 1993; 92:2152-2159

19 Staal-van den Brekel AJ, Dentener MA, Schols AMWJ, Buurman WA, Wouters EFM. Increased resting energy expenditure and weight loss are related to a systemic inflammatory response in lung cancer patients. J Clin Oncol 1995; 13:2600-2605

20 Seckinger P. Isaaz S, Dayer JM. Purification and biologic characterization of a specific tumor necrosis factor $\alpha$ inhibitor. J Biol Chem 1989: 264:11966-11973 
21 Engelmann H. Aderka D, Rubinstein M, Rotman D. Wallach D. A tumor necrosis factorbinding protein purified to homogeneity from human urine protects cells from tumor necrosis factor toxicity. J Biol Chem 1989; 264:11974-11980

22 Mountain CF. A new international staging system for lung cancer. Chest 1986; 89: 225s-233s

23 Patel AM, Dunn WF. Trastek. VF. Staging systems of lung cancer. Mayo Clin Proc 1993; 68: 475-482

24 Fredrix EWHM, Soeters PB, Von Meyenfeldt MF, Saris WHM. Measurement of resting energy expenditure in a clinical setting. Clin Nutrition 1990; 9:299-304

25 Fredrix EWHM, Soeters PB, Rouflart MMJ, von Meyenfeldt MF, Saris WHM. Resting energy expenditure in patients with newly detected gastric and colorectal cancer. Am J Clin Nutr 1991; 53:1318-1322

26 Hyltander A, Drot C, Körner U, Sandström R', Lundholm K. Elevated energy expenditure in cancer patients with solid tumours. Eur J Cancer 1991; 27:9-15

27 Hansell DT, Davies JWL, Burns HJG. The relationship between resting energy expenditure and weight loss in benign and malignant disease. Ann Surg 1986; 203:240-245

28 Lukaski HC, Johnson PE, Bolonchuk WW, Lykken GI. Assessment of fat-free mass using bioelectrical impedance measurements of the human body. Am J Clin Nutr 1985; 41:810-817

29 Deurenberg P. Weststrate JA. Paymans I, van der Kooy K. Factors affecting bioelectrical impedance measurements in humans. Eur J Clin Nutrition 1988; 42:1017-1022

30 Schols AMWJ, Dingemans ANC, Soeters PB, Wouters EFM. Within day variation of bioelectrical resistance measurements in patients with chronic obstructive pulmonary disease. Clin Nutrition 1990: 9:266-271

3I Chumlea WC, Baumgartner RN. Status of anthropometry and body composition data in elderly subjects. Am J Clin Nutrition 1989; 50: 1.158-1166

32 Zarowitz BJ, Pilla AM. Bioelectrical impedance in clinical practice. DICP. The Annals of Pharmacotherapy 1989; 23:548-555

33 Fredrix EWHM, Saris WHM, Soeters PB, Kester ADM, von Meyenfeldt MF, Wouters EFM, Westerterp KR. Estimation of body composition by bioelectrical impedance in cancer patients. Eur J Clin Nutrition 1990; 44:749-752:

34 Leeuwenberg JFM, Jeunhomme GMMA, Buurman WA. Slow release of soluble TNF-receptors by monocytes in vitro. J Immunology I994; I52:4036-4043

35 Froon AHM, Dentener MA, Greve JWM, Ramsay G, Buurman WA. L.PS toxicity regulating proteins in bacteremia. JIInf Dis 1995; 171:1250-1257

36 Engelberts I, Möller A. Schoen GJM, van der Linden CJ. Buurman WA. Evaluation of measurement of human TNF in plasma by ELISA. Lymphokine and Cytokine Res 1991; 10:69. 76.

37 Collichio FA, Woolf PD, Brower M. Management of patients with small cell carcinoma and the syndrome of ectopic corticotropin secretion. Cancer 1994; 73:1361-1367

38 Shepherd F, Laskey J. Evans W. Goss P, Johansen E. Khamsi F. Cushing's syndrome associated with ectopic corticotropin production and. small cell lung cancer. J Clin Oncol 1992; 10:21-27

39 Delisle L. Boyer MJ. Warr D, Killinger D. Payne D, Yeoh JC et al. Ectopic corticotropin syndrome and small cell carcinoma of the lung. Arch Int Med 1993; 153:746-752

40 Larsen K. Creatinine assay by a reaction-kinetic approach. Clin. Chem. Acta 1972; 41:209-217

41 Schols AMWJ. Fredrix EWHM, Soeters PB, Westerterp KP. Wouters EFM. Resting energy expenditure in patients with chronic obstructive pulmonary disease. Am J Clin Nutr 1991; 54:983-987

42 Goldstein S. Askanazi. J, Weissman C. Thomashow B, Kinney J. Energy expenditure in patients with chronic obstructive pulmonary disease. Chest 1987; 91:222-224

43 Quanjer PH. Standardized lung function testing. Bull Eur Physiopathol Respir 1983; 19:7-44 


\section{Chapter 3}

44 Ravussin E, Bogardus C. Relationship of genetics, age, and physical fitness to daily energy expenditure and fuel utilization. Am J Clin Nutr 1989; 49:968-975

45 Harris JA, Benedict FG. A biometric study of basal metabolism in man. Washington DC: Carnegie Institute of Washington Publication. 279, 1919

46 Froon AHM, Bemelmans MHA, Greve JW, van der Linden CJ. Buurman WA. Increased plasma concentrations of soluble tumor necrosis factor receptors in sepsis syndrome: correlation with plasma creatinine values. Crit Care Med 1994; 22:803-809

47 Brockhaus M, Bar-Khayim Y, Gurwicz S, Frensdorff A, Haran N. Plasma tumor necrosis factor soluble receptors in chronic renal failure. Kidney Int 1992; 42:663-667

48 SPSS/PC + Statistics 4.0 for the IBM.PC/XT/AT and PS/2, M.J. Norusis /SPSS Inc, New York 1990.

49 Westerterp K, Donkers J, Fredrix E, Boekhoudt P, Energy intake, physical activity and body weight: a simulation model

50 Engelberts I, Stephens S, Francot GJM, van der Linden CJ, Buurman WA. Evidence for direct effects of soluble TNF-receptors on various TNF measurements in human biological fluids. The Lancet 1991; 338:515-516

51 Falconer SJ, Fearon KCH, Plester CE, Ross JA, Carter DC. Cytokines, the acute-phase response and Resting Energy Expenditure in cachectic patients with pancreatic cancer. Ann Surg 1994; 219:325-331

52 Denz H, Orth B, Weiss G, Gallati H, Herrmann R, Huber P et al. Serum soluble tumour necrosis factor receptor 55 is increased in patients with haematological neoplasia ans is associated with immune activation and weight loss. Eur J Cancer 1993; 29a:2232-2235

53 Schaur RJ, Fellier H, Gleispach H. Tumor host relations. I. Increased plasma cortisol in tumorbearing humans compared with patients with benign surgical diseases. J Cancer Res Clin Oncol $1979 ; 93: 281-285$

54 Schaur RJ, Semmelrock HJ, Schauenstein E. Kronberger L. Tumor host relations. II. Influence of tumor extent and tumor site on plasma cortisol of patients with malignant diseases. J Cancer Res Clin Oncol $1979 ; 93: 287-292$ 


\title{
Chapter 4
}

\section{INCREASED RESTING ENERGY EXPENDITURE AND WEIGHT LOSS ARE RELATED TO A SYSTEMIC INFLAMMATORY RESPONSE IN LUNG CANCER PATIENTS}

\begin{abstract}
The aim of the present. study was to determine whether an increased resting energy expenditure (REE) and weight loss in lung cancer patients are related to a systemic inflammatory response. To this end REE was measured by indirect calorimetry using a ventilated hood system. Soluble Tumor Necrosis Factor Receptor 55 (sTNFR55) and sTNF-R75, soluble Intercellular Adhesion Molecule (sICAM)-1, sE-selectin, LPS-binding protein (LBP), Interleukin (IL)-6 and TNF- $\alpha$ were measured using sandwich ELISA and C-reactive protein (CRP) was measured by turbidimetry. A cross-sectional study was performed to compare inflammatory mediators between 1) hypermetabolic (REE/HB > 110\%) versus normometabolic (REE/HB $<110 \%$ ) patients and 2) weight losing (more than $10 \%$ weight loss of pre-illness weight) versus weight stable patients. Eighty-seven patients with primary non-small cell lung cancer were consecutively included into the study. Mean REE expressed as a percentage of the Harris Benedict reference values was $118 \pm 12 \%$ of predicted and 67 patients were considered hypermetabolic. 26 Patients had a substantial weight loss of more than $10 \%$ of their pre-illness weight. Hypermetabolic patients were found to have significantly elevated levels of sTNF-R55, sE-selectin, LBP and CRP in comparison with normometabolic patients. Weight loss was related with increased levels of the soluble TNF-receptors, sICAM-1, IL-6, LBP and CRP. In conclusion, hypermetabolism and weight loss are related to the presence of a systemic inflammatory response as reflected by enhanced levels of inflammatory mediators and acute phase proteins in patients with primary non-small cell lung cancer.
\end{abstract}




\section{Introduction}

Neoplastic diseases are frequently associated with metabolic alterations resulting in the clinical syndrome of cancer cachexia (i-3). Weight stable cancer patients have a better prognosis and a better response to treatment than weight losing patients (4-6). In general, weight loss is considered to be caused by energy imbalance, resulting from a decreased energy intake, an increased energy expenditure or a combination of these. An increased resting energy expenditure (REE) has been described for patients with various tumor types including lung cancer (7-10). Insight into the pathophysiology of these metabolic changes is essential for future interventions directed at reducing weight loss and improving survival in cancer patients.

Inflammatory mediators have been suggested to be involved in the metabolic derangements of cancer patients based on experimental animal studies (11-13). Key roles have been attributed to the inflammatory cytokines Tumor Necrosis Factor (TNF)- $\alpha$, Interleukin (IL)-1 and IL-6 (14-22). Increased IL-6 levels are reported in different malignancies $(23,24)$ whereas conflicting results are reported regarding the presence of TNF- $\alpha$ in peripheral blood of cancer patients (25-27). Moreover, recent data provide evidence for the involvement of IL-6 in experimental cancer cachexia in adenocarcinoma bearing mice (20-22).

In the present study we have investigated whether the metabolic derangements in lung cancer patients are related to a systemic inflammatory response in these patients. To this end we have investigated the relationship between the increase in energy expenditure, weight loss and the inflammatory response assessed by measurement of plasma levels of soluble TNF-receptor 55 (sTNF-R55) and sTNFR75, soluble intercellular adhesion molecule (sICAM)-1, sE-selectin, TNF- $\alpha$, IL-6 and the acute phase proteins LPS-binding protein (LBP) and C-reactive protein (CRP).

\section{Materials and methods}

\section{Patients and healthy individuals}

The study population consisted of 87 patients with primary non-small cell lung cancer consecutively evaluated between March 1992 and March 1994. The patients were admitted to the hospital for evaluation of the abnormalities on the chest X-ray. The exclusion criteria of the study were: previous treatment with chemotherapy, radiotherapy or surgery, treatment with high doses of steroids, severe endocrine abnormalities (insulin dependent diabetes mellitus, hyper/hypothyroidism), presence of manifest infections and body temperature above $37.7^{\circ} \mathrm{C}$. The TNM-classification was used for staging of non-small cell lung cancer $(28,29)$. Plasma samples of 26 healthy, age matched individuals $(13 \mathrm{~m} / 13 \mathrm{f})$ were used for control values of the 
inflammatory mediators. The study was approved by the medical ethical committee of the University Hospital of Maastricht. Written informed consent was obtained from all patients.

\section{Resting Energy Expenditure and body composition}

REE was measured by indirect calorimetry using a ventilated hood system (Oxycon $B^{*}$, Mijnhardt, Bunnik, The Netherlands). After an overnight fast and while at complete rest, $\mathrm{VO}_{2}$ and $\mathrm{VCO}_{2}$ were measured during a 20 -minute period. Flow through the canopy was kept constant during measurements and was adjusted to the weight of the patient ranging from 35 to $45 \mathrm{~L} / \mathrm{min}$. The equipment was calibrated at the start of every experiment. The within-subject variation in REE for healthy persons and patients with stable disease is smaller than $1.5 \%(\mathrm{p}>0.05)$ when measurements are repeated (30-32). The precision of the device was checked monthly by burning methanol with a theoretical RQ of 0.667 after complete combustion. Body height was measured bare foot standing and determined to the nearest $0.5 \mathrm{~cm}$. Body weight was measured to the nearest $0.1 \mathrm{~kg}$.

\section{Plasma samples}

Blood was obtained by venepuncture from patients before breakfast. Blood was collected in evacuated blood collection tubes (Sherwood Medical, St Louis, MO) containing 50 IU Heparin” (Leo Pharmaceutical Products B.V., Weesp, The Netherlands). Plasma was separated from blood cells by centrifugation at $1000 \mathrm{G}$ for 5 minutes within 1 hour after collection. Plasma samples were stored at $-70^{\circ} \mathrm{C}$ until analysis.

\section{Measurement of inflammatory mediators}

Inflammatory mediators were measured using sandwich ELISA that have been described elsewhere (33-37). In short, for measurement of sTNF-R55 and sTNFR75, MAbs MR1-1 and MR2-2 were used respectively for coating. Specific biotin labeled polyclonal rabbit anti-sTNF-K IgG were used as detector reagents. The standards used were recombinant human sTNF-R55 and sTNF-R75. The detection limit of both assays was $100 \mathrm{pg} / \mathrm{ml}$. Polyclonal rabbit anti human recombinant LBP IgG was used as coating for the LBP ELISA and biotin labeled polyclonal rabbit anti human recombinant LBP IgG was used for detection of LBP. The standard used was recombinant LBP. Washing and dilution was performed in buffer containing $40 \mathrm{mM}$ $\mathrm{MgCl}$ for preventing disturbance by LPS of LBP recovery in the ELISA. The detection limit of the assay was $200 \mathrm{pg} / \mathrm{ml}$. For sICAM-1 ELISA, mAb HM.2 was used for coating and recombinant human ICAM-1 was used as a standard. Biotinylated Mab HM.1 was used for detection. The detection limit of the assay was 


\section{Chapter 4}

$400 \mathrm{pg} / \mathrm{ml}$. For sE-selectin ELISA, plates were coated with Mab ENA1 and biotin labeled Mab ENA2 was used as detector reagens. $4 \mathrm{Mm} \mathrm{Ca}^{++}$and $2.5 \mathrm{Mm} \mathrm{Mg}^{++}$ was added to the buffers in this assay since binding of ENA1 and ENA2 to sEselectin is Ca-dependent. Standard used was recombinant human sE-selectin. The detection limit of the assay was $1 \mathrm{ng} / \mathrm{ml}$. The TNF- $\alpha$ ELISA consisted of $61 E 71$ as coating Mab and polyclonal rabbit anti-human TNF- $\alpha$ Abs. TNF- $\alpha$ could be detected with a lower detection limit of $20 \mathrm{pg} / \mathrm{ml}$. IL-6 was caught by $\mathrm{mAb} 5 \mathrm{E} 1$ and detected by polyclonal rabbit anti-human Il-6 Abs. IL-6 could be detected with a lower detection limit of $10 \mathrm{pg} / \mathrm{ml}$.

Immuno assay plates (Nunc-Immuno Plate Maxisorp, Roskilde, Denmark) were used for the ELISA assays. Biotinylated samples were detected with streptavidinperoxidase conjugate (Dako, Glostrup, Denmark), while peroxidase-conjugated goat anti-rabbit IgG (Jackson Immunoresearch, West Grove, PA) was used in the TNF- $\alpha$ and IL-6 ELISA. TMB (3,3',5,5'-tetramethylbenzidine, Kirkegaard \& Perry Lab., Gaithersburg, MD) was used as a substrate. Photo-spectometry $(450 \mathrm{~nm})$ was performed using a micro ELISA auto-reader.

CRP was measured by turbidimetry. The detection limit of the assay was $5 \mu \mathrm{g} / \mathrm{ml}$.

\section{Serum Creatinine}

Serum creatinine was used as a renal function parameter and detected by the modificated Jassé-reaction (Dimension, Dupont, France) (38).

\section{Statistics}

Measured REE was compared to predicted REE using the Harris Benedict (HB) equations (39). Subjects with a measured REE above $110 \%$ of predicted were considered hypermetabolic. This definition of hypermetabolism was based on Boothby's finding that $95 \%$ of normal individuals exhibit a measured REE within $10 \%$ of predicted (40) and confirmed by measurement of energy expenditure in healthy elderly people $(4 !, 42)$.

The percentage weight change from pre-illness stable weight $(6$ months before admission to the hospital) reported by the patient was used to divide the group of lung cancer patients into a weight stable $(<10 \%$ weight loss) and a weight losing group ( $>10 \%$ weight loss).

Groups were statistically compared using analysis of variance or the Mann-Whitney$\mathrm{U}$ test when appropriate. Since impaired renal clearance leads to increased sTNFreceptor levels $(43,44)$, the plasma levels of sTNF-R55 and sTNF-R75 were analysed together with serum creatinine. Therefore an analysis of covariance was performed, using plasma creatinine as covariable, and considering STNF-R55 and sTNF-R75 as factors in the statistical model. Correlations were determined using the Pearson's correlation coefficient. Frequency data were compared using the Chi- 
square test. Results were presented as mean $\pm \mathrm{SD}$. P-values $<0.05$ were defined as statistically significant. The statistical analyses were performed using the SPSS/PC+ 4.0 package $(45)$.

\section{Results}

\section{Patient characteristics}

Patient characteristics are summarized in Table 1. 68 Men and 19 women were included into the study. 35 Patients were classified as stage 1 and 2, 31 patients as stage 3 and 21 patients as stage 4 . Mean REE/HB for the whole group was $118 \pm$ $12 \%$ of predicted: 67 patients were hypermetabolic $(\mathrm{REE} / \mathrm{HB}>110 \%$ ). Mean weight loss was $3.5 \pm 4.9 \mathrm{~kg}$ for the whole group, while 26 of the 87 patients had a substantial weight loss of more than $10 \%$ of their pre-illness weight. All weight losing patients were hypermetabolic except for one (mean REE/HB $124 \pm 12 \%$ ).

Tumor stage was significantly different between weight losing and weight stable patients: 12 of the 26 patients $(46.2 \%)$ were considered stage IV in the weight losing group compared with 9 of the 61 patients $(14.6 \%)$ in the weight stable group $(p=0.006)$.

Table 1: characteristics of the study population

\begin{tabular}{lll}
\hline & $\begin{array}{l}\text { NSCLC } \\
(\mathrm{n}=87)\end{array}$ & $\begin{array}{l}\text { Controls } \\
(\mathrm{n}=26)\end{array}$ \\
\hline $\mathrm{m} / \mathrm{f}$ & $68 / 19$ & $13 / 13$ \\
age $(\mathrm{y})$ & $67 \pm 10$ & $59 \pm 5$ \\
weight $(\mathrm{kg})$ & $67.8 \pm 14.1$ & $75.1 \pm 9.8$ \\
height $(\mathrm{cm})$ & $168.7 \pm 7.8$ & $166.0 \pm 8.1$ \\
weight loss $(\mathrm{kg})$ & $3.5 \pm 4.9$ & 0 \\
REE $(\mathrm{kcal} /$ day $)$ & $1616 \pm 252$ & n.t. \\
REE (\% HB) & $118 \pm 12$ & n.t. \\
\hline
\end{tabular}

Data are expressed as mean $\pm s d, n . t .=$ not tested, $R E E=$ resting energy expenditure, $H B=$ Harris Benedict 


\section{Chapter 4}

Table 2: Hypermetabolism in lung cancer patients is associated with elevated levels of inflammatory mediators

\begin{tabular}{|c|c|c|c|}
\hline & $\begin{array}{l}\mathrm{REE} / \mathrm{HB}<110 \\
(\mathrm{n}=20)\end{array}$ & $\begin{array}{l}\mathrm{REE} / \mathrm{HB}>110 \\
(\mathrm{n}=67)\end{array}$ & p-value \\
\hline sTNF-R55 $(\mathrm{ng} / \mathrm{ml})$ & $\begin{array}{l}1.2 \pm 1.0 \\
1.0\end{array}$ & $\begin{array}{l}1.8 \pm 1.3 \\
1.3\end{array}$ & $<0.005$ \\
\hline sTNF-R75* (ng/ml) & $\begin{array}{l}2.1 \pm 1.2 \\
1.7\end{array}$ & $\begin{array}{l}2.3 \pm 1.6 \\
1.8\end{array}$ & n.s. \\
\hline $\operatorname{CRP}(\mu \mathrm{g} / \mathrm{ml})$ & $\frac{15}{5} \pm 23$ & $\begin{array}{c}41 \pm 36 \\
34\end{array}$ & $<0.001$ \\
\hline $\mathrm{LBP}(\mu \mathrm{g} / \mathrm{ml})$ & $\begin{array}{l}10.8 \pm 6.5 \\
8.5\end{array}$ & $\begin{array}{c}19.4 \pm 10.4 \\
19.3\end{array}$ & $<0.001$ \\
\hline sICAM-I (ng/ml) & $\begin{array}{l}64.4 \pm 29.2 \\
57.7\end{array}$ & $\begin{array}{l}71.7 \pm 29.1 \\
66.0\end{array}$ & N.S. \\
\hline sE-selectin (ng/mI) & $\begin{array}{c}26.4 \pm 12.7 \\
22.9\end{array}$ & $\begin{array}{c}35.9 \pm 23.7 \\
30.3\end{array}$ & $<0.05$ \\
\hline
\end{tabular}

Data are expressed as mean \pm sd, median $: n \cdot s .=$ not significant, ${ }^{*}=$ analysis of covariance adjusted for plasma creatinine, REE = resting energy expenditure, $H B=$ Harris Benedict, $s T N F$ $R 55=$ soluble $T N F$-receptor 55, sTNF-R75 $=$ soluble TNF-receptor 75, CRP $=C$-reactive protein, $L B P=L P S$ binding protein, sICAM-I = soluble Intercellular adhesion molecule-I

\section{Inflammatory mediators and hypermetabolism}

Control samples were obtained from 26 healthy, age matched individuals. The mean values ( $\pm \mathrm{sd}$ ) of the inflammatory mediators in plasma of the lung cancer patients in comparison with the healthy controls were as follows: sTNF-R55 $1.7 \pm 1.3$ versus $1.0 \pm 0.3 \mathrm{ng} / \mathrm{ml}(\mathrm{p}=0.01) ; \mathrm{sTNF}-\mathrm{R} 752.3 \pm 1.5$ versus $1.1 \pm 0.4 \mathrm{ng} / \mathrm{ml}(\mathrm{p}=<0.001)$; sICAM-1 $70.0 \pm 29.1$ versus $42.9 \pm 17.0 \mathrm{ng} / \mathrm{ml}(\mathrm{p}=<0.001)$; sE-selectin $33.7 \pm$ 22.0 versus $36.3 \pm 14.4 \mathrm{ng} / \mathrm{ml}(\mathrm{p}=0.2) ; \mathrm{CRP} 36 \pm 35$ versus $<5 \mu \mathrm{l} / \mathrm{ml}(\mathrm{p}=<0.001)$ and LBP $17.4 \pm 10.3$ versus $8.6 \pm 3.1 \mu \mathrm{g} / \mathrm{ml} \quad(\mathrm{p}=<0.001)$. TNF- $\alpha$ was not detectable with our assay in the plasma of the healthy individuals and the lung cancer population. IL-6 was not detectable in plasma of 23 healthy individuals $(88.5 \%)$, while IL-6 was only detectable in plasma of 41 lung cancer patients $(47.1 \%)$. Mean level for IL-6 in the lung cancer population was $40 \pm 70 \mathrm{pg} / \mathrm{ml}$. In order to investigate the relationship between hypermetabolism and the enhanced inflammatory response observed in the lung cancer population, we divided the patient population arbitrarily into a hypermetabolic (REE/HB $>110 \%$ ) and a normometabolic (REE/HB $<110 \%$ ) group. Significantly elevated concentrations of the inflammatory mediators sTNF-R55 and sE-selectin were found in the 
hypermetabolic group (Table 2). Also both acute phase proteins LBP and CRP were significantly elevated in the hypermetabolic group. Whereas the differences for sTNF-R55 and sE-selectin were small, the levels of the acute phase proteins in the hypermetabolic group were 2 to 3 times larger than in the normometabolic group. STNF-R75 and sICAM-1 showed no significant differences between both groups. Significant correlations existed between REE adjusted for HB and LBP $(r=0.37$, $p<0.001)$ and CRP $(r=0.43, p<0.001)$. No significant correlations were found for sTNF-R55, sTNF-R75, sE-selectin and sICAM-1. Mean levels of IL-6 for patients with detectable levels were $46 \pm 72 \mathrm{pg} / \mathrm{ml}$ for the hypermetabolic group versus $38 \pm$ $70 \mathrm{pg} / \mathrm{ml}$ for the normometabolic group $(\mathrm{p}=0.20)$. The patients with non-detectable levels of IL-6 $(\mathrm{n}=46)$ were equally divided among the hypermetabolic and normometabolic group $(\mathrm{p}=0.24)$. Normal renal function according to plasma creatinine $(84.6 \pm 26.2 \mu \mathrm{mol} / \mathrm{l})$ was found in the lung cancer patients.

Table 3: Patients with weight loss of more than 10\% of their original weight have higher levels of inflammatory mediators

\begin{tabular}{|c|c|c|c|}
\hline & $\begin{array}{l}\text { Weight loss }<10 \% \\
(n=61)\end{array}$ & $\begin{array}{l}\text { Weight loss }>10 \% \\
(\mathrm{n}=26)\end{array}$ & p-value \\
\hline REE (\%HB) & $\begin{array}{l}115 \pm 11 \\
112\end{array}$ & $\underset{125}{124 \pm 12}$ & 0.001 \\
\hline sTNF-R55 $(\mathrm{ng} / \mathrm{ml})$ & $\frac{1.4 \pm 1.1}{1.1}$ & $\begin{array}{l}2.3 \pm 1.5 \\
2.3\end{array}$ & $<0.001$ \\
\hline sTNF-R75" (ng/ml) & $2.1 \pm 1.4$ & $\begin{array}{l}2.8 \pm 1.7 \\
2.3\end{array}$ & $<0.001$ \\
\hline $\mathrm{CRP}(\mu \mathrm{g} / \mathrm{ml})$ & $\frac{26}{9} \pm 30$ & $\begin{array}{c}57 \\
55\end{array}$ & $<0.001$ \\
\hline $\mathrm{LBP}(\mu \mathrm{g} / \mathrm{ml})$ & $\begin{array}{c}15.1 \pm 9.4 \\
12.5\end{array}$ & $\begin{array}{l}22.7 \pm 10.3 \\
23.1\end{array}$ & 0.001 \\
\hline sICAM-I (ng/ml) & $\begin{array}{c}64.5 \pm 22.8 \\
61.1\end{array}$ & $\begin{array}{c}82.8 \pm 37.5 \\
71.5\end{array}$ & $<0.05$ \\
\hline sE-selectin (ng/ml) & $\begin{array}{c}31.8 \pm 15.4 \\
27.9\end{array}$ & $\begin{array}{l}38.2 \pm 32.6 \\
32.5\end{array}$ & n.s. \\
\hline
\end{tabular}

Data are expressed as mean $\pm s d$, median: $n . s . .=$ not significant, ${ }^{*}=$ Analysis of covariance adjusted for plasma creatinine, $R E E=$ Resting energy expenditure, HB $=$ Harris Benedict, $5 T N F$. $R 55=$ soluble $T N F$-receptor $55,5 T N F-R 75=$ soluble $T N F$-receptor $75, C R P=C$-reactive protein, $L B P=L P S$ binding protein, $s I C A M-I=$ soluble Intercellular adhesion molecule $-I$ 


\section{Inflammatory mediators and weight loss}

Next the putative relationship between the elevated inflammatory mediators and weight loss, an important clinical parameter of metabolic derangement in cancer patients, was investigated. To this end the lung cancer population was arbitrarily subdivided into a weight stable and a weight losing group (weight loss $\geq 10 \%$ of their pre-illness weight) (Table 3). The patients in the weight losing group were more hypermetabolic than patients with stable weight $(124 \pm 12$ versus $115 \pm 11$ $\%$ REE/HB, $p=0.001$ ). Furthermore significantly elevated levels of sTNF-R55, sTNF-R75 and sICAM were found in the weight losing group. The acute phase proteins were also significantly more elevated in the weight losing group in comparison with the weight stable group. In contrast, sE-selectin levels were not statistically different for both groups. Significant correlations existed between percentage weight loss and sTNF-R55 $(r=0.32, p<0.01)$, sICAM-1 $(r=0.29$, $\mathrm{p}<0.01)$ and the acute phase proteins $\operatorname{LBP}(\mathrm{r}=0.40, \mathrm{p}<0.001)$ and $\mathrm{CRP}(\mathrm{r}=0.41$, $p<0.001$ ). Mean levels for detectable IL-6 were significantly elevated for the weight losing group $(62 \pm 93 \mathrm{pg} / \mathrm{ml})$ in comparison with the weight stable group (37 $\pm 59 \mathrm{pg} / \mathrm{ml})(p<0.05)$. Patients with detectable levels of IL-6 occurred more in the weight losing group than in the weight stable group $(p=0.01)$.

\section{Discussion}

Elevated REE reflecting metabolic derangement in lung cancer patients as well as in patients with other types of cancer has been well established (7-10). This study is the first to describe the presence of elevated levels of inflammatory mediators in patients with primary lung cancer. Significantly elevated levels of both sTNFreceptors, sICAM-1 and the acute phase proteins LBP and CRP were found in plasma of lung cancer patients in comparison with healthy individuals. Increased REE, present in $77 \%$ of the lung cancer patients, was significantly related with enhanced levels of sTNF-R55, sE-selectin, CRP and LBP. Moreover, when patients were divided into a weight losing and a weight stable group, the weight losing group showed significantly enhanced plasma levels of the sTNF-receptors, sICAM-1, IL-6, LBP and CRP in comparison with the weight stable group.

In a former study, we have found that enhanced plasma levels of CRP in combination with rumor localization contribute to the elevated REE in lung cancer patients (10). These data and also data of others implicate the role of inflammatory processes in the metabolic derangements in cancer patients $(13,46)$. The purpose of the present study was to investigate the possible relationship between weight loss or hypermetabolism and the presence of cytokines, soluble adhesion molecules and the acute phase response in patients with primary lung cancer.

TNF- $\alpha$ is shown to cause anorexia and weight loss and is reported to be an 
important mediator in the clinical syndrome of cachexia in animals (14-18). Gelin e.a. (19) described the involvement of both $\mathrm{IL}-1$ and TNF- $\alpha$ in tumor growth and resulting weight loss in mice. Contradicting studies have been reported on the presence of TNF- $\alpha$ and $\mathrm{L}-1$ in plasma of patients (25-27). Biologically active TNF$\alpha$ was not detectable in our patient population. Biologically active TNF- $\alpha$ is difficult to detect because of its short half-time and the formation of complexes with the sTNF-receptors $(36,47)$. Since the presence of circulating TNF- $\alpha$ is reflected by enhanced levels of sTNF-receptors, we postulated that measurement of the sTNFreceptors would either indicate the presence of produced but not detectable levels of TNF- $\alpha$ or merely reflect the enhanced inflammatory status of the patient. Therefore we investigated the sTNF-receptor levels in plasma. The sTNF-receptors are considered to be the natural inhibitors of TNF- $\alpha(48,49)$. The regulatory mechanisms of both sTNF-receptors, however, are different for the different cell types $(33,50)$.

Our data show that both sTNF-receptors are related with weight loss in cancer patients, but only sTNF-R55 is significantly related with hypermetabolism. These data are supported by the reported relationship between sTNF-R55 and weight loss in patients with haematological malignancies (46). For both TNF-receptors, it should be recognized that they are not only elevated by inflammation, but also by impaired renal clearance since the kidney is reported to be the principal clearance organ for both sTNF-receptors $(43,44)$. All patients had normal renal function according to plasma creatinine thus excluding elevation of sTNF-receptors due to kidney dysfunction. Moreover, plasma creatinine was used as covariable in the analysis of covariance considering sTNF-R55 and sTNF-R75 as factors in the statistical model.

Recently, the inflammatory mediator IL-6 was also found to be involved in cachexia in mice bearing the colon 26 adenocarcinoma (20-22). In our patient population, we observed no differences for IL-6 levels between the hypermetabolic and the normometabolic group. However, the weight losing group showed enhanced levels of IL-6 in comparison with the weight stable group. These data are supported by reported elevated levels of IL-6 in plasma of weight losing patients with renal cell carcinoma (23).

The cytokines TNF- $\alpha, \mathrm{Il}-1$ and especially IL-6, are well known as pro-inflammatory cytokines responsible for the hepatic acute phase response. The observed enhanced levels of the acute phase parameters CRP and LBP in the hypermetabolic and weight losing patients strongly suggest that the inflammatory response is related with the metabolic derangements.

The presence of enhanced levels of the soluble adhesion molecules in the inflammatory process has been demonstrated in patients with haematopoietic tumors and gastrointestinal, ovarian and breast cancer $(51,52)$. The circulating adhesion molecules can either function by competing in cell-cell adhesion or merely represent an enhanced production. While E-selectin is only produced by activated 
endothelium, ICAM-1 is produced by many cell types and can be induced by cytokine stimulation (34). Hypermetabolic patients showed enhanced levels of sEselectin in comparison with normometabolic patients, while sICAM-1 was significantly elevated in the weight losing group in comparison with the weight stable group. Although several studies have reported elevated levels of the inflammatory mediators in cancer patients, only few studies have reported the possible association between weight loss or hyper-metabolism and the presence of cytokines and the acute phase response in cancer patients $(13,23,46)$. No other studies have reported elevated levels of soluble adhesion molecules in cancer patients in association with weight loss or hypermetabolism.

Further studies are needed to investigate whether the tumor itself is the origin of elevated levels of both TNF-receptors and/or adhesion molecules or the systemic inflammatory response of the patient is enhanced in response to the presence of the tumor. Moreover it remains to be elucidated whether the tumor itself or the response of the patient to the presence of the tumor is responsible for the metabolic disorders resulting in weight loss in cancer patients.

In conclusion, increased resting energy expenditure, present in $77 \%$ of the patients, was significantly related with elevated levels of sTNF-R55, sE-selectin, LBP and CRP. Besides, the sTNF-receptors, sICAM-1, LBP, CRP and IL-6 were significant= ly elevated in the group of patients with more than $10 \%$ weight loss of their preillness weight in comparison with the weight stable group. These data provide clinical evidence for the role of inflammation in the metabolic derangement in lung cancer patients. 


\section{References}

1. Langstein HN. Norton JA. Mechanisms of cancer cachexia. Hematol Oncol Clin N Am 1991; 5:103-123

2. Tisdale MJ. Cancer cachexia. Br J Cancer 1991; 63:337-342

3. DeWys WD, Begg PT, Lavin PR, et al. Prognostic effects of weight loss prior to chemotherapy in cancer patients. Am J Med 1980; 69:491-497

4. Van Eys J. Effect of nutritional status on response to therapy. Cancer Res 1982; 42:747-753 (suppl.)

5. Inagaki J, Rodriguez V, Bodey G. Causes of death in cancer patients. Cancer $1974 ; 33: 586-573$

6. Nathanson L. Hall TC. Lung tumors: how they produce their syndromes. Ann N Acad Sci $1974 ; 230: 367-377$

7. Hansell DT, Davies JWL, Burns HJG. The effects on resting energy expenditure of different tumor types. Cancer 1986; 58:1739-1744

8. Fredrix EWHM, Wouters EFM, Soeters PB, et al. Resting energy expenditure in patients with non-small cell lung cancer. Cancer 1991; 68:1616-1621

9. Russell DMcR, Shike $M_{\text {n }}$ Marliss EB, et al. Effects of total parenteral nutrition and chemotherapy on the metabolic derangements in small cell lung cancer. Cancer Res 1984; 44:1706-1711

10. Staal-van den Brekel AJ, Schols. AMWJ, ten Velde GPM, et al. Analysis of the energy balance in lung cancer patients. Cancer Res 1994; 54:6430-6433

11. Fearon KCH. The mechanisms and treatment of weight loss in cancer. Proc Nutr Soc 1992; 51:251-265

12. Kern KA. Norton JA. Cancer cachexia. JPEN 1988; 12:286-298

13. Falconer SJ, Fearon $\mathrm{KCH}_{4}$ Plester CE, et al. Cytokines, the acute-phase response and Resting Energy Expenditure in cachectic patients with pancreatic cancer. Ann Surg 1994; 219: 325-331

14. Tracey KJ, Wei H, Manogue KR, et al. Cachectin/Tumor necrosis factor induces cachexia, anemia, and inflammation. J Exp Med 1988; 167:121 i-1227

15. Fong $\mathbf{Y}$, Moldawer, Marano M, et al. Cachectin/TNF or IL-1 $\alpha$ induces cachexia with redistibution of body proteins. Am J Physioll 1989; 25:R659-R665

16. Smith BK, Kluger MJ. Anti-TNF- $\alpha$ antibodies normalized body temperature and enhanced food intake in tumor bearing rats. Am J Physiol 1993; 265: R615-R619

17. Costelli P, Carbo N, Tessitore $\mathrm{L}$, et al. Tumor Necrosis Factor $-\alpha$ mediates changes in tissue protein turnover in a rat cancer cachexia model. J Clin Invest 1993; 92:2783-2789,

18. Warren RS, Starnes HF, Gabrilove $\mathrm{JL}_{\text {n }}$ et al. The acute metabolic effects of tumor necrosis factor administration in humans. Arch Surg 1987; 122:1396-1400

19. Gelin J. Moldawer LL. Lönnroth C, et al. Role of endogenous tumor necrosis factor $\alpha$ and Interleukin I for experimental tumor growth and the development of cancer cachexia. Cancer Res 1991; 51:415-421

20. Strassman G. Fong M. Kenney JS, et al. Evidence for the involvement of interleukin 6 in experimental cancer cachexia. J Clin Invest 1992;89:1681-1684

21. Strassman G, Jacob CO, Evans R, et al. Mechanisms of experimental cancer cachexia, interaction between mononuclear phagocytes and colon-26 carcinoma and its relevance to IL-6 mediated cancer cachexia. J Immunol 1992; 148:3674-3678'

22. Strassmann G, Fong M, Freter CE, et all. Suramin interferes with Interleukin-6 receptor binding in vitro and inhibits colon-26-mediated experimental cancer cachexia in vivo. J Clin Invest 1993 92: 2152-2159

23. Dosquet C, Schaetz A, Faucher C, et al. Tumour Necrosis Factor- $\alpha$, Interleukin-1B and Interleukin-6 in patients with renal ceil carcinoma. Eur J Cancer 1994; 30A: 162-167 


\section{Chapter 4}

24. Plante M, Rubin SC, Wong GY, et. al. Interleukin-6 level in serum and ascites as a prognostic factor in patients with epithelial ovarian cancer. Cancer 1994; 73:1882-1888

25. Aderka D. Fisher $\mathrm{S}$, Levo $\mathrm{Y}$, et al. Cachectin/ tumor necrosis factor production by cancer patients. The Lancet 1985; 23: 1190

26. Balkwill $\mathrm{F}$, Osborne $\mathrm{R}$, Burke $\mathrm{F}$, et al, Evidence for tumour necrosis factor/cachectin production in cancer. The Lancet $1987 ; 28: 1229-1232$

27. Waage A, Espevik T, Lamvik J. Detection of TNF-like cytotoxicity in serum from patients with septicemia but not from untreated cancer patients. Scan J Immunol 1987; 24:739-744

28. Mountain CF. A new international staging system for lung cancer. Chest $1986 ; 89: 225 \mathrm{~s}-233 \mathrm{~s}$

29. UICC. Lung tumour. In: P. Hermanek, Sobin LH, eds., TNM classification of malignant tumours. Berlin Heidelberg New York London Paris Tokyo: Springer-Verlag 1987.

30. Murgatroyd PR, Davies HL, Prentice. AM. Intra-individual variability and measurement noise in estimates of energy expenditure by whole body indirect calorimetry. $\mathrm{Br} \mathbf{J}$ Nutr 1987; 58:347-356

31. Fredrix EWHM, Soeters PB, Von Meyenfeldt MF, et al. Measurement of resting energy expenditure in a clinical setting. Clin Nutrition 1990; 9:299-304

32. Schols AMWJ, Schoffelen P, Ceulemans $\mathrm{H}$, et al. Measurement of resting energy expenditure in patients with COPD in a clinical setting. JPEN 1992; 16:364-368

33. Leeuwenberg JFM, Jeunhomme GMMA, Buurman WA. Slow release of soluble TNF-receptors. by monocytes in vitro. J Immunol 1994; 152:4036-4043

34. Leeuwenberg JFM, Smeets EF, Neefjes JJ, et al. E-selectin and intercellular adhesion molecule$i$ are relased by activated human endothelial cells in vitro. Immunol 1992; 77:543-549

35. Froon AHM, Dentener MA, Greve JWM, et al. LPS toxicity regulating proteins in bacteremia. J Inf Dis 1995

36. Engelberts 1, Möller A, Schoen GJM, et al. Evaluation of measurement of human TNF in plasma by ELISA. Lymph.Cytokine Res. 1991; 10:69-76

37. Dentener MA, Bazil V, Von Asmuth EJU, et al. Involvement of CD14 in lipopolysaccharideinduced Tumor Necrosis Factor- $\alpha$, Interleukin- 6 and Interleukin- 8 release by human monocytes and alveolar macrophages. J Immunol 1993; 150: 2885-2891

38. Larsen K. Creatinine assay by a reaction-kinetic approach. Clin Chem Acta 1972; 41:209-217

39. Harris JA, Benedict FG. A biometric study of basal metabolism in man. Washington DC: Carnegie Institute of Washington, Publication 279, 1919

40. Boothby WM, Berkson J. Dunn HL. Studies on the energy of metabolism of normal individuals: a standard for basal metabolism with a nomogram for clinical application. Am J Physiology 1936: 3:468-483

41. Pannemans DLE, Bouten CVC. Westerterp KR. 24h Energy expenditure during a standardized activity protocol in young and elderly man. Eur J Clin Nutr 1995: 49:49-56

42. Vaughan L, Zurlo F, Kavussin E. Aging and energy expenditure. Am J Clin Nutr 1991;53: 821825

43. Froon AHM, Bemelmans. MHA, Greve JW, et al. Increased plasma concentrations of soluble tumor necrosis factor receptors in sepsis syndrome: correlation with plasma creatinine values. Critical Care Medicine 1994; 22:803-809

44. Brockhaus M. Bar-Khayim Y, Gurwicz S, et al. Plasma tumor necrosis factor soluble receptors in chronic renal failure. Kidney Int 1992; 42:663-667

45. SPSS/PC + Statistics 4.0 tor the IBM PC/XT/AT and' PS/2, M.J. Norusis/ SPSS Inc, New York 1990

46. Denz H. Orth B, Weiss G, et al. Serum soluble tumour necrosis factor receptor 55 is increased in patients with haematological neoplasia and is associated with immune activation and weight loss. Eur J Cancer 1993; 29a:2232-2235

47. Engelberts I. Stephens S, Francot G, et al. Evidence for different effects of sTNF-receptors on various TNF measurements in human biological tluids. The Lancet 1991: 338:515-516 
48. Seckinger P, Isaaz S, Dayer JM. Purification and biologic characterization of a specific tumor necrosis factor $\alpha$ inhibitor. J Biol Chem 1989; 264:11966-11973

49. Engelmann H, Aderka D, Rubinstein M, et al. A tumor necrosis factor-binding protein purified to homogeneity from human urine protects cells from tumor necrosis factor toxicity. J Biol Chem 1989; 264:11974-11980

50. Porteu $\mathrm{F}$. Hieblot $\mathrm{C}$. Tumor necrosis factor induces a selective shedding of its p75 receptor from human neutro- phils. J Biol Chem 1994; 269:2834-2840

51. Banks RE, Gearing AJH, Hemingway IK. Circulating intercellular adhesion molecule-I (ICAM1), E-selectin and vascular cell adhesion molecule-1 (VCAM-1) in human malignancies. Brit J Cancer 1993; 68: 122-124

52. Paoli de P, D'Andrea M, Santini G. Serum levels of adhesion molecules in haematopoietic tumuors. Immunol Today 1994; 15:339 



\title{
Chapter 5
}

\section{THE EXPRESSION OF TNF-RECEPTORS AND CYTOKINES \\ IN NON-SMALL CELL LUNG CARCINOMA}

\begin{abstract}
Both systemic and local inflammatory responses are observed in several types of cancer. It is assumed that the presence of tumor cells induces an inflammatory response leading to sequestration and activation of immune cells of the host. Tumor cells themselves and immune cells are able to produce different inflammatory cytokines. The aim of the present study was to investigate the local inflammatory response in non-small celi lung carcinoma. (NSCLC) by examining cytokine expression of different cell types. Immunoreactivity for TNF- $\alpha$, both TNF-recepiors (TNF-R), IL-6 and IL-8 was examined in and around the NSCLC cells. Cytokine patterns were related to the presence of inflammatory cells. Tumor cells showed slight to moderate staining for cytokines and both TNF-receptors independent of tumor type or differentiation grade. Normal bronchial epithelium showed similar staining patterns for TNF- $\alpha$, IL-6 and IL- 8 as the tumor cells, but did not show detectable staining for both TNF-receptors. The monocytes in tumor stroma and pneumocytes type II showed immunohistochemical staining for TNF- $\alpha$, IL- 6 i and IL8, while lymphocytes were positive for TNF-R75. The staining patterns observed indicate an activated status of only a minority of the inflammatory cells in tumor stroma. TNF-receptors could be demonstrated in NSCLC cells in contrast to normal bronchial epithelium.
\end{abstract}




\section{Introduction}

Both systemic and local inflammatory responses are observed in several types of cancer (1-3). Inflammatory cells, consisting of monocytes and lymphocytes, form part of the tumor stroma surrounding the tumor cells $(4,5)$. It is assumed that the presence of a tumor induces an inflammatory response characterized by sequestration and activation of the inflammatory cells of the host $(6,7)$. These activated cells produce different inflammatory cytokines. Moreover, tumor cells themselves are also able to produce inflammatory cytokines $(3,7-9)$. However, it is unknown whether tumor cells produce cytokines constitutively or as response to the presence of the inflammatory cells.

A key mediator of the inflammatory response is Tumor Necrosis Factor (TNF)- $\alpha$ $(10,11)$. The presence of TNF- $\alpha$ has been demonstrated in stroma of colorectal, renal cell, ovarian and breast carcinomas and in tumor cells by mRNA and protein studies (12-16). However, in most carcinomas only few tumor infiltrating mononuclear cells expressed genes for TNF- $\alpha$ in comparison to the abundant production of TNF- $\alpha$ in sites of chronic inflammatory lesions. TNF- $\alpha$ exerts its biological effects by binding to specific cell-surface receptors. Two distinct TNF- $\alpha$ binding molecules have been identified, the TNF-receptor 55 (TNF-R55) and TNF-R75. Both TNFreceptors are present on a broad range of cell types (17-19) and are upregulated and shed during inflammation $(11,19)$. Gatanaga e.a. (20) reported spontaneous release of both TNF-receptors by a human ovarian tumor cell line.

The presence of the pleiotropic cytokine IL-6 has also been reported in tumors. IL-6 mRNA has been detected in tumor cells of mice bearing the MCA/76-9 rhabdomyosarcoma (9). The involvement of IL-6 in experimental cancer cachexia has been demonstrated in adenocarcinoma bearing mice $(21,22)$. IL-6 also induces the production of acute phase proteins in the liver as observed in malignancy (2326). Recently, Xing e.a. (27) demonstrated that IL-6 caused profound local lymphocytic hyperplasia and massive lymphocytic infiltration in the pulmo-nary parenchyma of Sprague-Dawley rats after administration of a recombinant human type 5 adenovirus with rat IL-6 CDNA incorporated. IL-8 is another important chemokine for the lung (28-30), mRNA for IL- 8 and IL- 8 protein have been detected in lung cancer cell lines (3I). Both IL-6 and IL-8 are potential important parameters in the chemotactic process underlying sequestration of inflammatory cells into tumor stroma. In a previous study we investigated the systemic inflammarory response in NSCLC patients (32). Enhanced levels of sTNF-receptors and acute phase proteins in plasma were demonstrated in NSCLC patients. These data are in line with observations in other types of cancer patients $(1,2,33-36)$. The source, however, of these enhanced levels of sTNF-receptors is still unknown, but they appear to reflect a systemic inflammatory process in NSCLC.

The purpose of the present study was to investigate the local inflammatory response in non-small cell lung carcinoma (NSCLC) by examining cytokine expression of 
different cell types. To this end immunoreactivity for TNF- $\alpha$, TNF-R55, TNF-R75, II- 6 and IL-8 was examined in and around the tumor. This cytokine pattern was related to the presence of the inflammatory cells.

\section{Materials and methods}

\section{Tissues}

Tissues were consecutively collected from resection specimens of 48 NSCLC patients during thoracotomy. Tissue samples were selected from each specimen, fixed in $4 \%$ neutral buffered formaldehyde and embedded in paraffin $(n=48)$. In addition, samples were frozen in isopentane, immersed in liquid nitrogen and stored at $-70^{\circ} \mathrm{C}$. Cryostat sections were available from 43 patients.

\section{Immunohistochemistry}

The antibodies used for staining of cytokines and their receptors are shown in Table 1. TNF- $\alpha$, IL-6 and IL- 8 staining was performed on paraffin sections, while the staining for both TNF-receptors was performed on cryostat sections. Paraffin sections were dewaxed with xylene and rehydrated through graded concentrations of ethanol. To prevent endogenous peroxidase activity, sections were immersed in $0.6 \%$ hydrogen peroxide in methanol for 5 minutes. Pepsin $(0.1 \%$ pepsin in

Table 1: Specificities of the anibodies used for detection of cytokines and their receptors

\begin{tabular}{llll}
\hline Antibody (origin) & Antigen & Section & Source \\
\hline mAb 52B83 (murine IgG1) & TNF- $\alpha$ & Paraffin & $(37)$ \\
pAb $\alpha$-h-IL-6 (sheep) & IL-6 & Paraffin & L. V. Aarden (38) \\
pAb $\alpha$-h-IL-8 (rabbit) & IL-8 & Paraffin & R. Strieter (39) \\
mAb MR1-2 (murine IgG1) & TNF-R55 & Frozen & $(40)$ \\
mAb MR1-3 (murine IgG1) & TNF-R55 & Frozen & $(41)$ \\
mAb MR2-1 (murine IgG1) & TNF-R75 & Frozen & $(40)$ \\
mAb UTR-4 (murine IgG1) & TNF-R75 & Frozen & M. Brockhaus (42) \\
\hline
\end{tabular}

$m A b=$ monoclonal antibody, $p A b=$ polyclonal antibody 
$0.1 \mathrm{~N} \mathrm{HCL}$ ) was used as proteolytic enzyme for the IL-6 sections. Cryostat sections were cut at $5 \mu \mathrm{m}$ and taken up on poly-L-lysine coated slides. Slides were air dried and fixed in acetone at $-20^{\circ} \mathrm{C}$.

The following procedures were the same for both paraffin and cryostat tissues. Sections were incubated with the primary antibody diluted in Tris-buffered saline (TBS) with $1 \%$ BSA and $0.1 \%$ Tween 20 for 45 minutes at room temperature. After rinsing with TBS, rabbit-anti-mouse biotin (E413, Dako, Glostrup, Denmark), swine-anti-rabbit biotin (E431, Dako) or rabbit-anti-sheep biotin (313-065047, Jackson Immunoresearch, Westgrove, P.A.) was used. Subsequently, slides were incubated with streptavidin-biotin-horseradish-peroxidase complex (Dako) for 30 minutes. Peroxidase activity was visualized in a substrate solution containing diaminobenzidine (DAB) and Immidazole $(0.1 \mathrm{M}$ in Tris/HCL) to enhance the staining intensity. After optimal color development, sections were counterstained with Mayer's haematoxylin. Human tonsil was used as a positive control. For negative controls, primary antibodies were omitted and replaced by normal serum of mice, sheep or rabbit as control. The negative controls of the cryostat sections, which were not immersed in hydrogen peroxide, showed only distinct isolated staining in some macrophages. To ascertain the specificity of TNF-R55 and R75, immunostaining was evaluated in 10 parallel NSCLC sections through the use of two other monoclonal antibodies MR1-3 against TNF-R55 and UTR-4 against TNF-R75 in addition to MR1-1 and MR2-1.

The antibodies used for cell identification are shown in Table 2. Subsequent slides were cut and investigated for the specific markers of macrophages/monocytes, Tand B-lymphocytes and cytokines.

Table 2: Specificities of the anitbodies used for characterization of the inflammatory cells

\begin{tabular}{llll}
\hline Antibody & CD & Section & Source \\
\hline DAKO-MAC & CD68 & Paraffin & Dako, Glostrup, Denmark \\
Pan-B & CD20 & Paraffin & Dako \\
OKT-3 & CD3 & Paraffin & Dako \\
Dako-HLA-DR & NC & Paraffin & Dako \\
\hline
\end{tabular}

$N C=$ not clustered 
TNF-receptor and cytokine expression in NSCLC
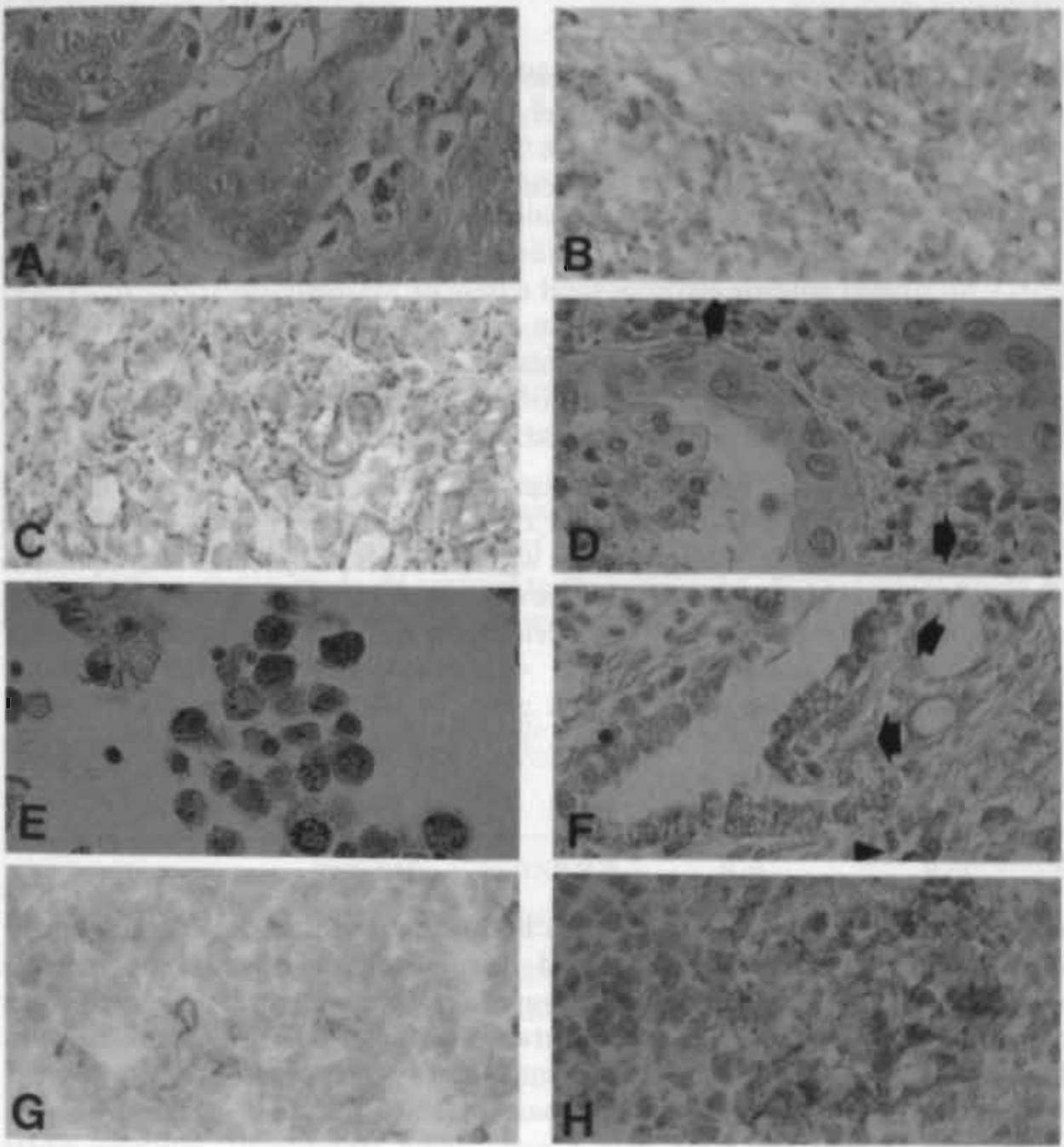

\section{Legend to Figure 1}

Immunohistochemical staining on NSCLC is shown for different antibodies, all photographs have the same magnification $(x 360)$ Different squamous cell carcinomas with immunoreactivity for TNF- $\alpha$ (A), TNF-R55 (B) and TNF-R75 (C). Macrophages within tumor stroma are clearly possitive (D) for IL-8 (arrows). Alveolar macrophages (E) show a heterogeneous staining pattern for TNF- $\alpha$. Immunoreactivity for IL-6 (F) is shown in pneumocytes type II (arrows) and plasma cells (arrow head). Occasionally, lymphocytes (G) show a membraneous staining pattern for TNF-R75. Clear immunoreactivity for TNF-RS5 is seen in germinal centers $(H)$. 


\section{Chapter 5}

\section{Histological evaluation}

The distribution and intensity of immunohistochemical staining with the various antibodies were assessed semi-quantitatively in two ways: a) percentage of each cell type showing immunoreactivity absent, $<25 \%, 25-75 \%,>75 \%$ and b) amount of staining product divided arbitrarily in absent, slight, moderate and strong immunoreactivity.

\section{Results}

\section{Patients}

Specimens of 48 NSCLC patients were examined for immuno- reactivity. The group consisted of 35 men and 13 women with a mean age of 66 y (range 43-81 y). The distribution of the histologic classification was as follows: 19 patients with squamous cell carcinoma, 21 patients with adenocarcinoma, 2 patients with adenosquamous cell carcinoma and 6 patients with large cell carcinoma. The differentiation grade of squamous cell carcinoma was: well $\mathrm{n}=2$, moderately $\mathrm{n}=10$ and poorly differentiated $\mathbf{n}=7$, the differentiation grade of adenocarcinoma: well $\mathbf{n}=8$, moderately $n=2$, poorly differentiated $n=11$ and adenosquamous carcinoma was moderately differentiated $(\mathbf{n}=2)$.

\section{Inflammatory cells}

In order to differentiate the inflammatory infiltrate around the tumor cells, specific markers for $\mathrm{T}$ - and B-lymphocytes and macrophages/monocytes were used on paraffin sections. In general, lymphoid aggregates were present to a variable extent at the edge of the NSCLC fields or in between the outer fields of carcinoma cells. The aggregates consisted mainly of B-lymphocytes with scattered T-lymphocytes. Lymphocytes were found in tumor stroma of NSCLC. Most of them were Tlymphocytes, except for areas with a very dense lymphocytic infiltrate where occasionally B-lymphocytes were demonstrated. In some sections, T-lymphocytes were focally present in between carcinoma cells.

CD68 reactive monocytes were present in great numbers in tumor stroma. CD68 was also detected on small cells in between carcinoma cells and on macrophages in alveolar compartments. HLA-DR positivity was found in tumor stroma and in between carcinoma cells as well. Also pneumocytes type II were frequently positive for HLA-DR. Follicular aggregates were heterogeneously stained, sometimes aggregates were strongly positive, other times aggregates were negative. Occasionally, HLA-DR positivity was found on tumor cells. 
In general, immunohistochemical staining for TNF- $\alpha$ was diffuse but weak in the cytoplasm of $25-75 \%$ of tumor cells in 31 out of 48 sections (Fig 1). Distribution according to tumor type or differentiation grade did not reveal differences in staining patterns between the different tumor types or grades. Bronchial epithelium of large and smaller airways showed slight staining in 27 (out of 29) sections while the pneumocytes type II were moderate positive for TNF- $\alpha$ in 27 (out of 28) sections. (Fig 1). Alveolar macrophages showed a heterogeneous staining pattern for TNF- $\alpha$, varying from none to strong intensity. A minority of the plasma cells and monocytes in tumor stroma showed slight to moderate staining for TNF- $\alpha$, but lymphocytes did not demonstrate immunoreactivity for TNF- $\alpha$. No immunoreactivity for TNF- $\alpha$ was found in endothelium. All immunohistochemical findings for the cytokines and their receptors are clustered in Table 3.

Evaluation of TNF-R55 expression revealed a diffuse slight to moderate cytoplasmic staining in the NSCLC cells in 33 out of 43 sections (Fig 1) independent of tumor type or differentiation grade. In contrast to the tumor cells, bronchial epithelium and pmaumanytac type II did not chow immunoreactivity for TNF-R55.

Table 3: The results of the immunohistochemically evaluated inflammatory mediators in the differen cell types in and around the numor in 48 cases of NSCLC

\begin{tabular}{|c|c|c|c|c|c|c|c|c|c|c|}
\hline & \multicolumn{2}{|l|}{ TNF- $\alpha$} & \multicolumn{2}{|c|}{ TNF-R55 } & \multicolumn{2}{|l|}{ TNF-R75 } & \multicolumn{2}{|l|}{ IL-6 } & \multicolumn{2}{|l|}{ IL-8 } \\
\hline & Int. & n. & Int. & n. & Int. & n. & Int. & n. & Int. & n. \\
\hline Tumor & $\pm 1+$ & $65 \%$ & $\pm 1+$ & $79 \%$ & \pm & $42 \%$ & \pm & $24 \%$ & $\pm 1+$ & $76 \%$ \\
\hline Br. Epith. & $\pm 1+$ & $55 \%$ & - & - & - & .. & $\pm 1+$ & $20 \%$ & $\pm 1+$ & $59 \%$ \\
\hline Pneum.II & $+1++$ & $55 \%$ & - & - & - & - & $+1++$ & $49 \%$ & $\pm 1+$ & $53 \%$ \\
\hline AlvMacr. & $+1++$ & $82 \%$ & - & $\cdots$ & - & - & $+1++$ & $73 \%$ & +++ & $92 \%$ \\
\hline Monocyt & $+1++$ & $82 \%$ & $\ldots$ & - & - & $\cdots$ & $+1++$ & $73 \%$ & $++1+$ & $+76 \%$ \\
\hline Lymph. & - & - & - & - & $+1++$ & $92 \%$ & -. & -. & - & - \\
\hline $\mathrm{Pl}$ cell & $\pm 1+$ & $82 \%$ & - & -. & - & - & $++1++$ & $-86 \%$ & $\pm 1+$ & $65 \%$ \\
\hline Endoth. & - & - & - & -. & - & - & - & $\ldots$ & $\ldots$ & - \\
\hline
\end{tabular}

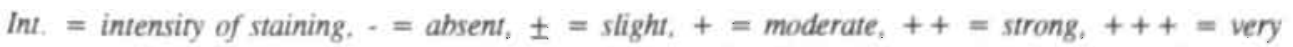
strong: $n=$ percentage of cases with immunoreactivity; $\mathrm{Br}$. Epith. = bronchial epithelium; Pneum. II = pneumocytes type II; AlvMacr = alveolar macrophages; Monocyt = monocytes in tumor stroma; Lymph. = lymphocytes; $P$ l. cell = plasma cell; Endoth. $=$ endothelium 
The inflammatory cells were negative for TNF-R55. However, if lymphoid aggregates with germinal centers were present, a moderate staining for TNF-R55 was visible in the germinal centers (Fig 1). Endothelium did not show immunoreactivity for TNF-R55.

A diffuse, weak cytoplasmic staining for TNF-R75 was found for the tumor cells in 19 out of 43 sections (Fig 1). No relationship between staining and tumor type or differentiation grade was found for TNF-R75 as well. Bronchial epithelium of the large and smaller airways and pneumocytes type II did not stain for TNF-R75. Less than $25 \%$ of the lymphocytes stained moderately for TNF-R75 with a membraneous pattern (Fig 1), while no other inflammatory cells in the stroma showed TNF-R75 expression. Staining of sections of 10 patients with another mAb to TNF-R55 (MR13) and mAb to TNF-R75 (UTR-4) resulted in identical staining patterns as obtained with $\mathrm{mAb}$ MR1-2 and mAb MR2-1.

\section{II-6}

A weak cytoplasmic staining for IL-6 was found in the NSCLC cells in 12 sections. However, the majority of tumor cells lacked immunoreactivity for IL-6. Bronchial epithelium showed moderate positive staining for IL-6 in $25-75 \%$ of the cells (10 out of 38 ) and pneumocytes type II (24 out of 28) stained moderately to strongly (Fig 1). Alveolar macrophages showed a heterogeneous staining pattern for IL-6 as reported above for TNF- $\alpha$. However, a higher number of alveolar nacrophages was positive for IL- 6 than for TNF- $\alpha$. Plasma cells showed moderate to strong staining for IL-6 in 42 sections, while lymphocytes did not stain. A minority of monocytes compared to the total number of CD68 positive cells in tumor stroma were immunoreactive for IL-6. No staining for IL-6 was found in endothelium.

\section{IL-8}

IL-8 staining was demonstrated in the majority of the tumor cells with a slight to moderate intensity $(\mathrm{n}=35)$. Bronchial and bronchiolar epithelium showed a different staining pattern. Bronchial epithelium was more diffusely stained with a slight tomoderate intensity in 28 (out of 34) sections while bronchiolar epithelium (23 out of 25) showed a distinct supranucleolar staining with a moderate to strong intensity. Pneumocytes type II, when present, were slightly to moderately stained for IL-8. In almost every section, part of the alveolar macrophages were strongly positive for IL-8. Therefore, they were used as internal controls for the assessment of staining intensity. Less than $25 \%$ of the monocytes were recognizable in the stroma between the tumor cells in 28 sections and stained with a moderate to strong intensity (Fig 1). Less than $25 \%$ of plasma cells were moderately positive for IL- 8 while lymphocytes and endothelial cells did not stain for IL-8. 


\section{Discussion}

The present study describes cytokine expression of the different cell types in NSCLC. The tumor cells showed slight to moderate staining for the cytokines and both TNF-receptors independent of tumor type or differentiation grade. Normal bronchial epithelium showed similar staining patterns for TNF- $\alpha$, IL- 6 and IL- 8 as the tumor cells, but lacked immunoreactivity for both TNF-receptors. Pneumocytes type II and less than $25 \%$ of the monocytes in tumor stroma showed immunohistochemical staining for TNF- $\alpha$, IL-6 and IL-8, while less than $25 \%$ of the lymphocytes were positive for TNF-R75. This staining pattern supports the viewpoint that only a minority of the inflammatory cells in tumor stroma are in an activated status as shown for the markers investigated.

Evaluation of both TNF-receptors in tumor tissue revealed diffuse slight to moderate cytoplasmic staining of the tumor cells. TNF-R55 staining of the tumor cells was present in more sections and staining was more intense than for TNF-R75. The diffuse cytoplasmic staining pattern of tumor cells strongly suggests enhanced TNFreceptor production by tumor cells, but mRNA studies are needed to ascertain local production. Our data are in line with an in vitro study of Gatanaga e.a. (20) who reported that TNF-R55 was the predominant form of the TNF-receptors spontaneously released by a human ovarian tumor cell line. Shimomoto et al. (43) demonstrated TNF-R75 mRNA in 40\% of the lung cancer cell lines. However their immunohistochemi-cal data differed from our data since they were not able to detect TNF-R75 expression on NSCLC cells (43). TNF- $\alpha$ has been demonstrated to enhance the release and production of TNF-receptors $(11,19)$. Both the presence of activated inflammatory cells and the local presence of TNF- $\alpha$ might be responsible for increased expression of both TNF-receptors on NSCLC cells. Shedding of TNFreceptors by tumor cells could function in counteracting the antitumor effects of TNF- $\alpha(20,44)$.

It is assumed that NSCLC cells arise from bronchial epithelium (45). Bronchial epithelium showed the same staining pattems for TNF- $\alpha$, IL-6 and IL- 8 as the NSCLC cells and these data are supported by others $(39,46,47)$. Bronchial epithelium, however, lacked detectable immmunoreactivity for both TNF-receptors, while NSCLC cells showed substantial staining for both TNF-receptors. Both tumor cells themselves and the surrounding inflammatory cells could be responsible for the upregulation of TNF-receptors by local enhanced TNF- $\alpha$ levels. Shimomoto et al. (43), however, was able to detect TNF-R55 expression on bronchioles but not on alveolar epithelial cells with the use of different antibodies.

The cells in the environment of the tumor cells which represent an inflammatory status can be subdivided into monocytes, lymphocytes and pneumocytes type II. Less than $25 \%$ of the monocytes in tumor stroma showed immunostaining for TNF$\alpha$, IL- 6 and IL- 8 indicative for an activated status. The tumor cells might be responsible for induction of activation of the inflammatory cells since both activating 


\section{Chapter 5}

and inhibiting factors are produced by tumor cells as reported before $(3,6-8)$. Beissert et al. demonstrated that only a small proportion of tumor infiltrating monocytes produce TNF- $\alpha$ in colorectal cancer, while macrophages in surrounding tissues lacked TNF- $\alpha$ mRNA (15). Immunosuppressive molecules such as Nitric Oxide, Prostaglandin $\mathrm{E}_{2}$ and IL-10 are produced by macrophages in the environment of the tumor (48-50). These immunosuppressive molecules could contribute to the reduced expression of cytokines by the inflammatory cells in tumor stroma. In addition, TNF- $\alpha$ mediates both cytotoxicity and suppression of antitumor lymphocyte responses as well (8).

Tumor growth is highly dependent of the process of angiogenesis in and around the tumor. TNF $-\alpha$ is angiogenic in vivo as has been demonstrated before $(51,52)$. Local enhanced produc-tion of TNF- $\alpha$ by tumor cells itself or inflammatory cells could thus play a role in tumor growth by enhancing angiogenesis. IL-8 has also been shown to be a primary mediator of angiogenesis in bronchogenic carcinoma (53). In this way, II- 8 could influence neovascularization and stroma formation of the tumor necessary for the growth of tumor cells (54).

IL-6 has only recently been discovered as a chemokine for lymphocytes in the lung (27). In line with these data, we demonstrated large numbers of T-lymphocytes in NSCLC tumor stroma. In the present study, part of the tumor infiltrating lymphocytes showed enhanced expression of TNF-R75. Other studies demonstrated that most resting B- and T-lymphocytes expressed small amounts of TNF-R75 and that TNF-R75 was markedly upregulated after activation (55-57). Our data suggest therefore that part of the lymphocytes around the tumor ceils are activated. Cytotoxic T-cells form the majority of the tumor infiltrating lymphocytes along with helper T-cells and B-cells in the lung as reported before with immuno-phenotypic studies $(58,59)$. TNF-R55 expression was confined to germinal centers with a characteristic staining pattern (56). Local production of TNF- $\alpha$ by dendritic reticulum cells has been detected in the germinal center $(60)$. The presence of TNF$\alpha$ could thus induce TNF-R55 expression in the germinal center and regulate the immtine response:

Pneumocytes type Il increase in number under inflammatory conditions (61). Pneumocytes type II stained positive for TNF- $\alpha$, IL- 6 and IL- 8 . Our IL- 6 and IL- 8 data are supported by Crestani e.a. who demonstrated that pneumocytes type II produce IL-6 and IL-8 in vivo and in vitro under appropriate conditions (62) and by Nash e.a. (63) who reported immunohistochemical staining for TNF- $\alpha$ in pneumocytes type II of patients with ARDS. The positive staining pattern of pneumocytes type II for the cytokines and HLA-DR are suggestive for an active role of pnetmocytes type II in the local inflammatory process around the NSCLC cells.

We were not able to relate the systemic plasma levels of the inflammatory mediators in NSCLC patients with the local expression of these inflammatory mediators in and around the NSCLC cells (data not shown).

In conclusion, NSCLC cells show immunohistochemical staining for TNF- $\alpha$, IL-6, 
IL- 8 and both TNF-receptors. Bronchial epithelium shows similar staining patterns for the cytokines, but lacks TNF-receptor staining. Pneumocytes type Il and part of the monocytes in tumor stroma showed immunohistochemical staining for TNF- $\alpha$, IL-6 and IL-8, while less than $25 \%$ of the lymphocytes were positive for TNF-R75. These staining patterns reflect the activated inflammatory status of inflammatory cells (monocytes, lymphocytes and pneumocytes type II) and the upregulation for TNF-receptors in NSCLC. 


\section{Chapter 5}

\section{References}

1. Dosquet C, Schaetz A, Faucher C, Lepage E, Wautier JL, Richard F, Cabane J. Tumour necrosis factor- $\alpha$, Interleukin- $1 B$ and Interleukin- 6 in patients with renal celj carcinoma. Eur J Cancer 1994; 30A: 162-167

2. Falconer SJ, Fearon KCH, Plester CE, Ross JA, Carter DC. Cytokines, the acute phase response and resting energy expenditure in cachectic patients with pancreatic cancer. Ann Surg 1994; $219: 325-331$

3. Tabibzadeh SS, Poubouridis D, May LT, Sehgal PB. Interleukin-6 immunoreactivity in human tumors. Am J Pathol 1989; $135: 427-433$

4. Dvorak HF. Tumors: wounds that do not heal. Similarities between tumor stroma generation and wound healing. N Engl I Med 1986; 315:1650-1659

5. Robbins SL, Cotran RS. Kumar V. Pathologic basis of disease Ed. 3, Edized by Saunders WB. Philadelphia, 1984; 258-261

6. Erroi A, Sironi M, Chiaffarino F, Zhen-Guo C, Mengozzi M, Mantovani A. IL-! and IL-6 release by tumor-associated macrophages from human ovarian carcinoma. Int J Cancer 1989; 44:795-801

7. Mantovani A, Bottazzi B, Colotta F, Sozzani S, Ruco L. The origin and function of rumorassociated macrophages. Immunol Today i992; 13:265-270

8. Alleva DG, Burger C.I. Elgen K.D. Tumor-induced regulation of suppressor macrophage nitric oxide and TNF- $\alpha$, production. J Immunol 1994: 153:1674-1686

9. Evans R, Fong M, Fuller J, Karndar S. Meyerhardt J, Strassmann G. Tumor cell IL-6 gene expression is regulated by $\mathrm{IL}-\mathrm{I} \alpha / \mathrm{B}$ and TNF- $\alpha$ : proposed feedback mechanisms induced by the interaction of tumor cells and macrophages. J Leukoc Biol 1992; 52:463-468

10. Beutler B, Cerami A. Cachectin and tumour necrosis factor as two sides of the same biological coin. Nature 1986; 320:584-588

11. Fiers W. Tumor necrosis factor, characterization at the molecular, cellular and in vivo level. FEEBS 1991; 285: 99-212

12. Miles DW. Happerfield LC, Naylor MS, Bobrow LG, Rubens RD. Balkwill FR. Expression of umour necrosis factor (TNF- $\alpha$ ) and its receptors in benign and malignant breast tissue. Int J Cancer 1994; $56: 77-782$

13. Vitolo D. Zerbe T, Kanbour A, Dahl C, Herberman RB, White-side TL. Expression of mRNA for cytokines in tumor-infiltrating mononuclear cells in ovarian adenocarcinoma and invasive breast cancer. Int $\mathbf{J}$ Cancer 1992; $51: 73.580$

14. Naylor MS Stamp GWH, Balkwill FR. Investigation of cytokine gene expression in human colorectal cancer. Cancer Res 1990: 50:4436-4440

15. Beisserı S, Bergholz M, Waase I, Lepsien G, Schauer A, Pfizenmaier K, Krönke M. Regulation of tumor necrosis factor gene expression in colorectal adenocarcinoma: in vivo analysis by in situ hybridization. Proc Natl Acad Sci 1989; 86:5064-5068

16. Waase I, Bergholz M, Iglauer A, Beissert S, Blech M, Schauer A, Krönke M. Heterogeneity of Tumour Necrosis Factor production in renal cell carcinoma. Eur J Cancer 1992; 28A: I660-I664

17. Tartaglia L, Goeddei DV. Two TNF-receptors. Immunol Today 1992; 13:151-153

18. Hohmann HP. Remy R, Brockhaus M, van Loon APGM. Two different cell types have different major receptors for human tumor necrosis factor (TNF- $\alpha$ ). J Biol Chem 1989; 264: 14927-14934

19. Ding AH, Porteu F: Regulation of tumor necrosis factor receptors on phagocytes. PSEBM 1992: $200: 458-465$

20. Gatanaga M, Grosen EA, Burger RA, Granger GA, Gatanaga T. Release of soluble TNF/LT receptors from a human ovarian tumor cell line (PA-1) by stimulation with cytokines in vitro. Lymphokine Cytokine Res 1993; 12:249-253 
21. Strassman G, Fong M. Kenney JS, Jacob CO. Evidence for the involvement of Interleukin 6 in experimental cancer cachexia. J Clin Invest 1992; 89:1681-1684

22. Strassman G, Jacob CO, Evans R, Beall D, Fong M. Mechanisms of experimental cancer cachexia, interaction between mononuclear phagocytes and colon-26 carcinoma and its relevance to IL-6 mediated cancer cachexia. J Immunol 1992; 148:3674-3678.

23. Heinrich P. Castell J, Andus T. Interleukin 6 and the acute phase response. Biochem J 1990; 265:621-636

24. Hirano T, Akira S, Taga T, Kishimoto T. Biological and clinical aspects of Interleukin 6. Immunol Today 1990; 11:443-449

25. Raynes JG, Cooper EH. Comparison of serum amyloid A protein and C-reactive protein concentrations in cancer and non-malignant disease. J Clin Pathol 1983; 36:798-803

26. Weinstein PS, Skinner M, Sippe JD, Lokich J, Zamcheck N, Cohen AS. Acute phase proteins or tumour markers: the role of SAA, SAP, CRP and CEA as indicators of metastasis in a broad. spectrum of neoplastic diseases. Scand J Immunol 1984; 19:193-198

27. Xing Z, Braciak T, Jordana M. Croitoru K, Graham FL, Gauldie 3. Adenovirus-mediated cytokine gene transfer at tissue sites, overexpression of IL-6 induces lymphocytic hyperplasia in the lung. J Immunol 1994; 153:4059-4069

28. Kunkel SL, Standiford T, Kasahara K, Strieter RM. Interleukin-8: The major neutrophil chemotactic factor in the lung. Exp Lung Res 1991; 17:17-23

29. Baggiolini M, Walz A, Kunkel SL. Neutrophil-activating peptide-1/Interleukin 8, a novel cytokine that activates neutrophils. J Clin Invest 1989; 84: 1045-1049

30. Rot A. Endothelial cell binding of NAP-1/IL-8: role in neutrophil emigration. Immunol Today 1992: 13:291-294

31. Mizuno K, Sone S, Orino E, Mukaida N, Matsushima K, Ogura T. Spontaneous production of Interleukin- 8 by human lung cancer cells and its augmentation by Tumor necrosis factor alpha and Interleukin-I at protein and mRNA levels. Oncology 1994; 51:467-47I

32. Staal-van den Brekel AJ, Dentener MA, Schols AMWJ, Buurman WA, Wouters EFM. Increased resting energy expenditure and weight loss are related to a systemic inflammatory response in lung cancer patients. J Clin Oncol 1995; 13:2600-2605

33. Denz H, Orth B, Weiss G, Gallati H, Herrmann R, Huber P, Wachter H, Fuchs D. Serum soluble tumour necrosis factor receptor 55 is increased in patients with haematological neoplasias and is associated with immune activation and weight loss. Eur J Cancer 1993; 29a:2232-2235

34. Waage A, Liabakk N. Lien E, Lamvik J, Espevik T. P55 and p75 Tumor Necrosis Factor receptors in patients with chronic lymphocytic leukemia. Blood 1992; 80:2577-2583

35. Grosen EA, Yamamoto RS, Ioli G. Ininns EK, Gatanaga M, Gatanaga T, Disaia PJ, Berman M, Manetta A. Granger GA. Blocking factors (soluble membrane receptors) for tumor necrosis factor and lymphotoxin detected in ascites and released in short-term cultures obtained from ascites and solid tumors in women with gynecologic malignancy. Lymphokine Cytokine Res $1992 ; 11: 347-353$

36. Aderka D, Engelmann H, Hornik V, Skornick V, Levo Y, Wallach D, Kushtai G. Increased serum levels of soluble receptors for Tumor Necrosis Factor in cancer patients. Cancer Res 1991; 51:5602-5607

37. Tarlow MJ, Jenkins R, Comis SD, Osborne MP. Stephens S, Stanley P, Crocker J. Ependymal cells of the choroid plexus express tumour necrosis factor- $\alpha$. Neuropathology and applied Neurobiology 1993; 19:324-328

38. Helle M, Boeije L, de Groot E, de Vos A, Aarden L. Sensitive ELISA for Interleukin-6. Detection of IL-6 in biological fluids: synovial fluids and sera. J Immunol Meth 1991: 138:47. 56

39. Standiford TJ, Kunkel SL. Basha MA, Chensue SW, Lynch III JP, Toews GB, Westwick J, Strieter RM. Interleukin-8 gene expression by a pulmonary epithelial cell line: a model for 


\section{Chapter 5}

cytokine networks in the lung. J Clin Invest 1990; 86:1945-1953

40. Leeuwenberg JFM, Dentener MA, Buurman WA. Lipopolysaccharide LPS-mediated soluble TNF receptor release and TNF receptor expression by monocytes. J Immunol 1994; 152: 50705076

41. Leukocyte Typing Workshop, Boston. Edited by Schlossmann, 1994, in press

42. Brockhaus M, Schoenfeld HJ, Schlaeger EJ, Hunziker W, Lesslauer W, Loetscher HR: Identification of two types of tumor necrosis factor receptors on human cell lines by monoclonal antibodies. Proc Natl Acad Sci 1990; 87:3127-3131

43. Shimomoto H, Hasegawa Y, Nozaki Y, Takagi N, Shibagaki T, Nakao A, Shimokata K. Expression of tumor necrosis factor receptors in human lung cancer cells and normal lung tissues. Am J Respir Cell Mol Biol 1995; 13:271-278

44. Olsson I, Gatanaga T, Gullberg U, Lantz M, Granger GA. Tumour necrosis factor (TNF) binding proteins (soluble TNF receptor forms) with possible roles in inflammation and malignancy. Eur Cytokine Netw 1993; 4:169-180

45. Robbins SL, Cotran RS, Kumar V. Pathologic basis of disease Ed. 3, Edited by Saunders WB. Philadelphia, 1984; 749-757

46. Cromwell O, Hamid Q, Corrigan CJ, Barkans J, Meng Q. Collins PD, Kay AB. Expression and generation of Interleukin-8, IL-6 and granulocyte-macrophage colony stimulating factor by bronchial epithelial cells and enhancement by IL-1B and tumour necrosis factor $-\alpha$. Immunology 1992: 77:330-337

47. Spriggs DR, Imamura K, Rodriguez C, Sariban E, Kufe DW. Tumor necrosis factor expression in human epithelial tumor cell lines. J Clin invest 1988; 81:455-460

48. Moore KW, O'Garra A, de Waal Malefyt R, Vieira P, Mosmann T. Interleukin 10. Annu Rev Immunol 1993; 11:165-190

49. Alleva DG, Elgerı KD. Promotion of macrophage-stimulated autoreactive $T$ cell proliferation by Interleukin-10: counteraction of macrophage suppressor activity during tumor growth. Immunobioll 1995; 192:155-171

50. Hibbs JB, Taintor RR, Vavrin Z, Rachlin EM. Nitric oxide: a cytotoxic-activated macrophage effector molecule. Biochem Biophys Res Commun 1988; 157:87-93

51. Frater-Schröder M, Risau W, Hallmann R, Gautschi P, Böhlen P. Tumor necrosis factor type $\alpha$, a potent inhibitor of endothelial cell growth in vitro, is angiogenic in vivo. Proc Natl Acad Sci $1987 ; 84: 5277-5281$

52. Leibovich SJ, Polverini PJ, Shepard HM, Wiseman DM, Shively V, Nuseir N. Macrophageinduced angiogenesis is mediated by tumour necrosis factor- $\alpha$. Nature 1987; 329:630-632.

53. Smith DR, Polverini PJ, Kunkel SL, Orringer MB, Whyte RI, Burdick MD, Wilke CA, Strieter RM. Inhibition of Interleukin 8 attenuates angiogenesis in bronchogenic carcinoma. J Exp Med 1994: 179: 1409-1415

54. Folkman J, Cotran R. Relation of vascular proliferation to tumor growth. Int Rev Exp Pathol $1976 ; 16: 207-211$

55. Erikstein BK, Smeland EB, Blomhoff HK, Funderud S, Prydz K, Lesslauer W, Espevik T: Independent regulation of $55-\mathrm{kDa}$ and $75-\mathrm{kDa}$ tumor necrosis factor receptors during activation of human peripheral blood B lymphocytes. Eur J Immunol 1991; 21:1033-1037

56. Ryffel B, Brockhaus M, Greiner B, Mihatsch MJ, Gudat F. Tumoụr Necrosis Factor receptor distribution in human lymphoid tissue. Immunology 1991: 74:446-452

57. Dembic Z, Loetscher H, Gubler U, Pan YE, Lahm HW, Gentz R, Brockhaus MI, Lesslauer W. Two human TNF receptors have similar extracellular, but distinct intracellular, domain sequences. Cytokine 1990; 2:231-237

58. Whiteside TL, Jost LM, Herberman RB. Tumor infiltrating lymphocytes. Potential and limitations to their use for cancer therapy. Crit Rev Oncol Hematol 1992; 20:25-47

59. Vitolo D, Palmieri MB, Ruco L.P, Rendina E, Bonsignore G, Baroni CD. Cytokine production 
and expression of adhesion molecules and integrins in tumor infiltrating lymphomononuclear cells of non-small cell cacrinomas of the lung. Am J Pathology 1994; 145:322-329

60. Ruco LP, Stoppacciaro A, Pomponi D, Boraschi D, Santoni A, Tagliabue A, Uccini S, Baroni CD. Immunoreactivity for $\mathrm{IL-1}$ beta and TNF alpha in human lymphoid and nonlymphoid tissues. Am J Pathology 1989; 135:889-897

61. Mason J, Williams MC. Type II alveolar cell. Defender of alveolus. Am Rev Respir Dis 1977; 116:81-91

62. Crestani B, Cornillet P. Dehoux M, Rolland C, Guenounou M, Aubier M. Alveolar type II epithelial cells produce Interleukin-6 in vitro and in vivo, regulation by alveolar macrophage secretory products. J Clin Invest 1994; 94:731-740

63. Nash JRG, McLaughlin PJ, Hoyle C, Roberts D. Immunolocalization of tumour necrosis factor $\alpha$ in lung tissue from patients dying with adult respiratory distress syndrome. Histopathology 1991; 19:395-402 



\title{
EXPRESSION OF E-SELECTIN, INTERCELLULAR ADHESION MOLECULE (ICAM)-1 AND VASCULAR CELL ADHESION MOLECULE (VCAM)-1 IN NON-SMALL CELL LUNG CARCINOMA
}

\begin{abstract}
Vascular cell adhesion molecules play an important role in the regulation of inflammation and are considered to be important for the process of malignant tumor growth. The present study describes the immunohistochemical staining patterns of E-selectin, ICAM-1 and VCAM-1 on endothelial cells of the vessels in tumor stroma and other cell types in non-small cell lung carcinoma (NSCLC) $(n=43)$ in association with inflammatory cells.

E-selectin expression was dominant on endothelial cells in the stromal areas of the tumor, especially in the borders of the tumor. E-selectin expression was confined to endothelial cells. Moderate to strong staining for ICAM-1 was demonstrated on endothelial cells irrespective of size or localization of the vessels. Compared to ICAM-1, less vessels stained positive for VCAM-1 with less intensity as well. ICAM-1 expression was demonstrated on NSCLC cells, the basal cells of bronchial epithelium, pneumocytes type II, lymphocytes and fibroblasts. VCAM-I was. expressed distinctly on NSCLC cells in 4 out of 43 cases, on lymphocytes and fibroblasts. The staining patterns observed on endothelial cells support the viewpoint. of an active status of NSCLC vessels. This phenotypic pattern looks similar to the vascular component of inflammation. The presence of ICAM-1 and VCAM-1 on NSCLC cells suggests a functional role in the process of chemotaxis for tumor cells as well.
\end{abstract}




\section{Introduction}

Vascular cell adhesion molecules play an important role in the regulation of inflammatory processes. Adhesive interactions between cells and extracellular matrix are necessary for the adhesion and extravasation of leukocytes. The upregulation of adhesion molecules on endothelial cells is a characteristic feature for the inflammatory status $(1,2)$. Adhesion and transmigration of leukocytes is a multiple step process consisting of rolling of leukocytes, triggering by chemokines and strong adhesion of the leukocytes to the endothelial cells, followed by transendothelial migration of the leukocytes as reviewed by many authors (3-5). Eselectin, belonging to the family of the selectins, is involved in the process of rolling of the mononuclear cells. E-selectin is expressed on vascular endothelial cells, but only when the latter are activated by inflammatory processes in vivo or by bacterial endotoxin and/or cytokines in vitro (6-8). Intercellular Adhesion Molecule (ICAM)1 (CD54) and Vascular Cell Adhesion molecule (VCAM)-1 belong to the immunoglobulin supergene family and are both involved in the process of strong adthesion of mononuclear cells to the endothelial cells (1-5). ICAM-1 is constitutively expressed on endothelial cells and is upregulated in response to endotoxin, TNF- $\alpha, \mathrm{IL}-1$ or IFN- $\tau(1,8,9)$. It is also present on the surface of mononuclear phagocytes and other non-immune cells such as fibroblasts and epithelial cells $(1,8,9)$. VCAM- 1 is not constitutively expressed on endothelial cells, but can be induced in the presence of IL-1, TNF- $\alpha$ or IL-4 (10-12). VCAM-1 is expressed on several non-vascular cell types, including populations of dendritic cells found in lymph node and skin, bone marrow, stromal cells and synovial cells in inflamed joints (1).

Adhesive interactions between tumor cells and adjacent cells or extracelluar matrix are considered to be important for the process of malignant tumor growth. The activation of endothelial cells by inflammatory cytokines causes an increase in adthesion of tumor cells in vitro (13-15). Alterations in expression of vascular cell adhesion molecules have been reported in a variety of malignant tissues in vivo (1620). E-selectin is absent in normal skin, but is strongly expressed by dermal endothelium in both squamous cell carcinomas and basal cell carcinomas $(16,17)$. increased ICAM-1 expression is correlated with melanoma tumor progression and an increased risk of metastases (18), while VCAM-1 expression has been demonstrated in nasopharyngeal carcinomas with a lymphoepi-thelioma aspect and in melanomas $(19,20)$.

In a former study we have investigated the systemic inflammatory response in nonsmall cell lung carcinoma (NSCLC) patients (21). Enhanced levels of soluble (s) Tumor Necrosis Factor (TNF)-receptors and acute phase proteins in plasma were demonstrated in NSCLC patients. In addition we found elevated levels, of sICAM-1 in peripheral blood of NSCLC patients, sE-selectin levels were not different from healthy controls. 
The aim of the present study was to investigate the expression of adhesion molecules, as parameter of immune activation, on endothelial cells in tumor stroma, on NSCLC cells and other cell types in the environment of the tumor. To this end the expression of E-selectin, ICAM-1 and VCAM-1 in association with inflammatory cells was investigated.

\section{Materials and methods}

Tissues were consecutively collected from resection specimens of 43 patients undergoing thoracotomy for non-small cell lung carcinoma in the University Hospital of Maastricht. TNM-classification was used for staging of the patients (22). Tissue samples were selected from each specimen and frozen in isopentane. Samples were immersed in liquid nitrogen and stored at $-70^{\circ} \mathrm{C}$.

Paraffin sections were dewaxed with xylene and rehydrated through graded concentrations of ethanol. To prevent endogenous peroxidase activity, sections were immersed in $0.6 \%$ hydrogen peroxide in methanol for 5 minutes. Cryostat sections were cut at $5 \mu \mathrm{m}$ and taken up on poly-L-Lysine coated slides. Slides were air dried under a fan for 15 minutes and fixed in acetone at $-20^{\circ} \mathrm{C}$. Sections were not immersed in hydrogen peroxide. Consecutive sections were immunostained with monoclonal mouse antibodies directed against the following adhesion molecules: ESelectin (ENA-1) 1:25 dilution (20), ICAM-1 (RR-1, a kind gift of Dr. R. Rothlein, Boehringer Ingelheim Pharmaceuticals, Inc., Ridgefield CT) 1:800 dilution (30) and VCAM-1 (1G11, kindly provided by Dr. D.O. Haskard, Rheumatology Unit, Hammersmith Hospital, London, U.K.) I:25 dilution (40). Polyclonal rabbit-antifactor VIII (A082, Dako, Glostrup, Denmark) at 1:2000 dilution was used to detect vessels in the sections. The antibodies were diluted in Tris-buffered saline (TBS) with $1 \% \mathrm{BSA}$ and $0.1 \%$ Tween. Sections were incubated with the primary antibody for 45 minutes. After rinsing with TBS, rabbit-anti-mouse biotin (E413, Dako) incubation was performed for 30 minutes. Subsequently slides were incubated with streptavidin-biotin-horseradisch-peroxidase complex (Dako) for 30 minutes. Peroxidase activity was visualized in a substrate solution containing diaminobenzidine (DAB). Immidazole $(0.1 \mathrm{M}$ in Tris/HCl) was added to enhance staining intensity. After optimal color development, sections were counterstained with Mayer's haematoxylin. For negative controls, primary antibodies were omitted and replaced by normal serum of mice as control. Negative controls showed only distinct isolated staining in some macrophages (see Fig. Id).

The following antibodies were used for cell identification: DAKO-MAC (Dako), 1:100 dilution for CD68, Pan-B (Dako), 1:1000 dilution, for CD20, OKT-3 (Dako), 1:200 dilution for CD3 and Dako-HLA-DR (Dako) 1:50 dilution. Subsequent paraffin slides were cut and investigated for the specific markers of macrophages/monocytes and T- and B-lymphocytes. 


\section{Chapter 6}

The distribution and intensity of immunohistochemical staining with the various antibodies were assessed semi-quantitatively in two ways: a) percentage of each cell type showing immunoreactivity; absent, $<25 \%, 25-75 \%,>75 \%$ and b) amount of staining product divided into; absent, slight, moderate and strong immunoreactivity. The number of vessels staining positive for the adhesion molecules was subjectively compared with the number of vessels detected with Factor VIII in consecutive sections.

The relation between immunohistochemical staining patterns of the different cell types and tumor stage or histologic differentiation was tested using the Friedman test for non-parametric data. The statistical analyses were performed using the SPSS/PC +4.0 package (37).

Table I: Clinical and histological characteristics

\begin{tabular}{lll}
\hline Clinical characteristics & male / female & $34 / 9$ \\
Histologic type & age (mean \pm sd) & $65 \pm 10$ \\
Squamous cell carcinoma & Differentiation grade & $\mathrm{N}$ \\
& well & 3 \\
Adenocarcinoma & moderately & 9 \\
& poorly & 5 \\
Adenosquamous carcinoma & well & 6 \\
Large cell carcinoma & moderately & 2 \\
\hline
\end{tabular}

$N=$ number of patients

\section{Results}

Forty-three NSCLC specimens were examined for immunoreactivity with ESelectin, ICAM-1 and VCAM-1. The clinical characteristics and the distribution of the histological classification are summarized in Table 1.

To differentiate the inflammatory infiltrate around the tumor cells, specific markers for T- and B-lymphocytes and macrophages/monocytes were used on paraffin sections. In general, lymphoid aggregates were present to a variable extent at the edge of the NSCLC fields or in between the outer fields of carcinoma cells. The aggregates consisted mainly of B-lymphocytes with scattered T-lymphocytes. 

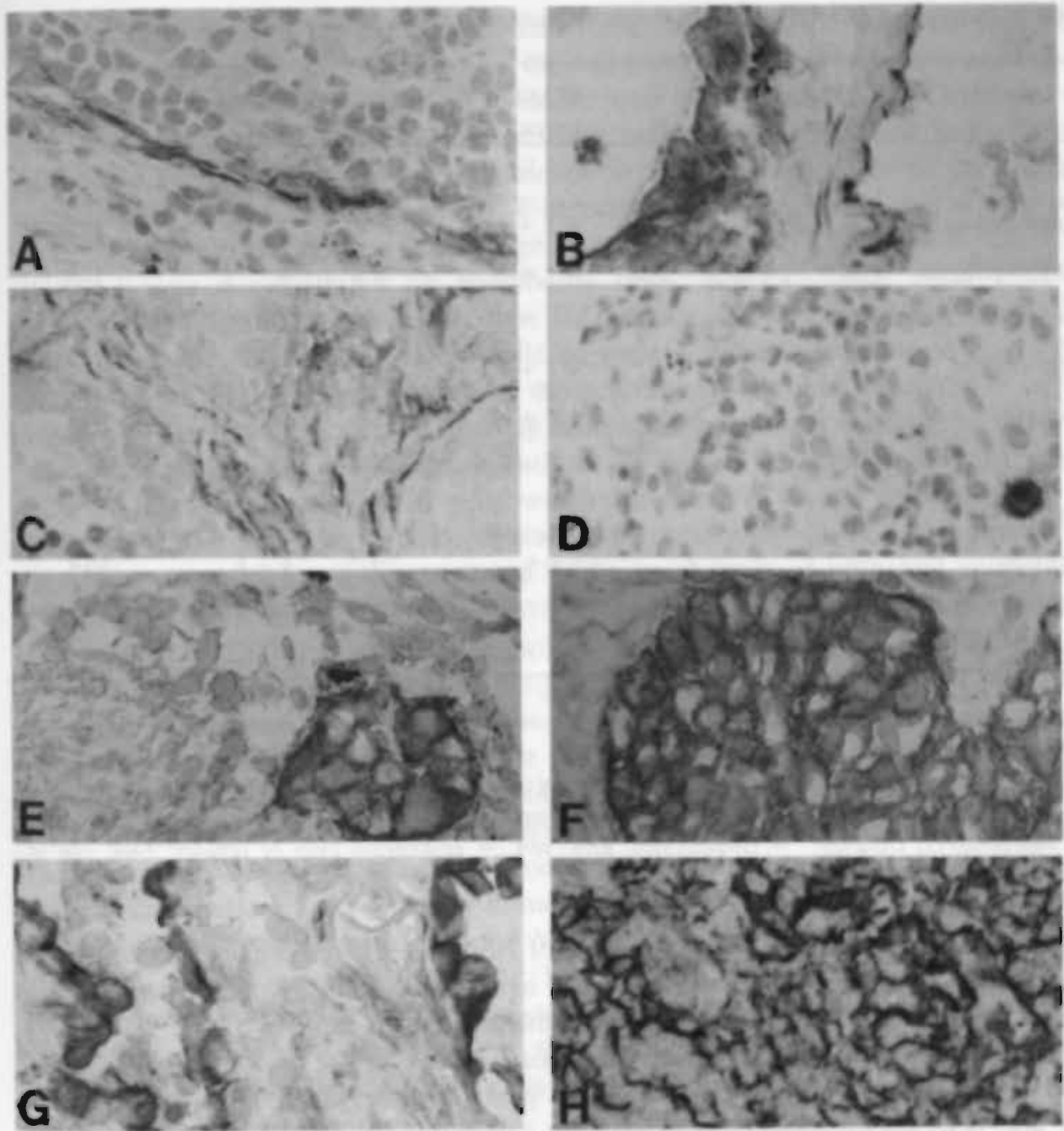

\section{Legend to Figure 1}

Immunohistochemical staining is shown for different antibodies. Immunoreactiviry on endothelial cells is shown for E-selectin (A), ICAM-I (B) and VCAM-I (C). Distinct staining of solitary macrophages is shown in the negative control (D). NSCLC cells are clearly immunoreactive for ICAM-I (E) and VCAM-I (F). ICAM-I expression is demonstrated on pneumocytes type II (G). A typical membranous staining pattern of lymphocytes was observed for VCAM-I (H). All photographs have the same magnification $(x 360)$. 
Table 2: Description of the immunohistochemical results

\begin{tabular}{|c|c|c|c|c|c|c|}
\hline & $\begin{array}{l}\text { E-Selectin } \\
\text { Intens. }\end{array}$ & $\mathrm{N}$ & $\begin{array}{l}\text { ICAM-1 } \\
\text { Intens. }\end{array}$ & $\mathrm{N}$ & $\begin{array}{l}\text { VCAM-1 } \\
\text { Intens. }\end{array}$ & $\mathrm{N}$ \\
\hline \multicolumn{7}{|l|}{ NSCLC } \\
\hline -squam.cell ca. & - & & $+1++$ & $76 \%$ & + & $12 \%$ \\
\hline -adenocarcinoma & - & & $+1++$ & $72 \%$ & + & $11 \%$ \\
\hline -adenosquam.ca. & - & & - & - & - & - \\
\hline -large cell ca. & - & & $+1++$ & $57 \%$ & - & - \\
\hline Br. epith & - & & $+1++$ & $71 \%$ & 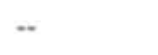 & - \\
\hline Pneum. II & - & & $+1++$ & $53 \%$ & - & - \\
\hline Mono/macro. & - & & - & - & - & - \\
\hline Lymphoc. & -. & & $+t+$ & $100 \%$ & +++ & $93 \%$ \\
\hline End, ven. & $++1+++$ & $79 \%$ & $++1+++$ & $97 \%$ & $+1+++$ & $97 \%$ \\
\hline End. cap. & $++1+++$ & $79 \%$ & $++1+++$ & $100 \%$ & $+1++$ & $100 \%$ \\
\hline
\end{tabular}

Intens. = Intensity; $-=$ absent,$+=$ slight, $++=$ moderate, $+++=$ strong; $N=$ percentage of positive cases; $N S C L C=$ non-small cell lung carcinoma; Squam. cell $c a .=$ squamous cell carcinoma; adenosquam $c a .=$ adenosquamous carcinoma; large cell $c a .=$ large cell carcinoma; Br. epith. = bronchial epithelium; Pneum. II = pneumocytes type II; Mono/macro. $=$ monocytes and marophages; Lymphoc $=$ lymphocytes; End ven. $=$ endothelial cells of venules; End cap $\cong$ endothelial cells of capillaries.

Lymphocytes were found in tumor stroma of NSCLC. These lymphocytes consisted usually of T-lymphocytes, except for areas with a very dense lymphocytic infiltrate where occasionally B-lymphocytes were demonstrated. In some sections, T-lymphocytes were focally present in between carcinoma cells.

CD68 reactive monocytes were present in great numbers in tumor stroma. CD68 was also detected on small cells in between carcinoma cells and on macrophages in alveolar compartments. HLA-DR positivity was found in tumor stroma and in between carcinoma cells as well. Also pneumocytes type II were frequently positive for HLA-DR. Follicular aggregates were heterogeneously stained for HLA-DR. Some aggregates with germinal centers were strongly positive, while the majority of aggregates, showing no germinal centers, were negative. Occasionally, HLA-DR positivity was found on tumor cells.

Immunoreactivity for E-selectin in the different cell types is summarized in Table 2. E-Selectin expression was confined to endothelial cells (see Fig. 1a). No other cell types expressed E-selectin. Twenty-five to $75 \%$ of the vessels showed strong immunostaining for E-selectin in 34 out of 43 sections. In all sections there were 
more vessels positive for factor VIII than for E-selectin. Differences in size were arbitrarily made between capillaries on the one hand and larger vessels containing at least one layer of smooth muscle cells in the wall on the other hand. There was no difference in staining intensity for E-selectin between the smaller or larger vessel sizes. E-selectin expression was dominant in the stromal areas of the tumor, especially in the borders of the tumor. E-selectin expression on endothelial cells was independent of tumor type or tumor stage.

ICAM-1 was demonstrated on endothelial cells, NSCLC cells, basal cells of bronchial epithelium, pneumocytes type II, lymphocytes and fibroblasts (Table 2). More than $75 \%$ of the endothelial cells of vessels stained moderate to strong for ICAM-1 (see Fig. 1b) irrespective of the central or peripheral localization of the vessels in the tumor. Moderate to strong immunohistochemical staining for ICAM-1 was found in $>75 \%$ of the tumor cells in 30 out of 43 sections (see Fig. 1e). ICAM-1 expression on NSCLC cells was independent of tumor type $(p=0.44)$ or stage $(p=0.81)$. When bronchial epithelium was present $(n=7)$, ICAM-1 expression (moderate to strong) was demonstrated in the basal layer of bronchial epithelium. Pneumocytes type II were present in 8 sections and showed slight to moderate staining (see Fig. 1g). Fibroblasts in tumor stroma were positive for ICAM-1 in all sections. Twenty-five to $75 \%$ of the lymphocytes were positive for ICAM-1 and had a typical membranous staining pattern with a strong intensity. These staining patterns were also demonstrated in the germinal centers when present. The other cells of the mononuclear infiltrate did not express immunostaining for ICAM-1.

Next to the endothelial cells, immunohistochemical staining for VCAM-1 was demonstrated on NSCLC cells, lymphocytes and fibroblasts (Table 2). Endothelial cells of the capillaries were slightly to moderately stained for VCAM-1, while larger vessels showed immunoreactivity for VCAM=1 in $25-75 \%$ of the vessels with a slight to strong intensity (see Fig. 1c). In comparison with the staining of endothelium for ICAM-1, less vessels stained positive for VCAM-1 and the staining intensity for VCAM-1 was also less than for ICAM-1. No correlation between VCAM-1 expression on endothelial cells and tumor stage or histologic type could be demonstrated. The majority of tumor cells did not show immunoreactivity for VCAM-1. However, distinct immunostaining for VCAM-1 could be demonstrated in 4 NSCLC cases (see Fig. If). Bronchial epithelium and pneumocytes type II did not show any immunoreactivitiy for VCAM-1. Fibroblasts in tumor stroma were positive for VCAM-1 in all sections. Twenty-five to $75 \%$ of the lymphocytes were positive for VCAM-1 and had a typical membranous staining pattern with a strong intensity (see Fig. Ih). These staining patterns were also demonstrated in the germinal centers when present. The monocytes and alveolar macrophages did not express immunostaining for VCAM-1. 


\section{Discussion}

The present study describes the immunohistochemical staining patterns of E-selectin, ICAM-1 and VCAM-1 on endothelial cells of the vessels in tumor stroma of NSCLC. In addition, the expression of ICAM- 1 and VCAM- 1 was demonstrated on NSCLC cells and other cell types in the vicinity of the tumor cells.

The contribution of tumor blood vessels to the process of immune cell infiltration and host immune response is considered to be essential for the process of growth and metastasis. In the absence of local capillary proliferation and delivery of oxygen and nutrients, neoplasms cannot grow. The density of vessels in the tumor is of importance for the rapidity of growth of the tumor (25-27). The tumor vessels, in contrast to normal blood vessels, have been reported to be fragile, thin walled and devoid of normal supportive nervous and muscular components essential for normal vasomotor responses (28). In addition to being irregular in size, shape and distribution, tumor blood vessels are lined by highly proliferative immature endothelial cells (28). E-selectin and VCAM-1 are normally not expressed on endothelial cells in the lung, but are upregulated during inflammatory conditions $(2,10-12)$. The active participation of blood vessels in the local inflammatory process around tumor cells is supported by the present finding of expression of Eselectin and VCAM-1 on endothelial cells. No differences for VCAM-1 and ICAM1 expression on the vessels are found with regard to the central or peripheral localization of the vessels in the tumor. However, several sections show more immunostaining for E-selectin on vessels in the borders than in the center of the tumor. E-selectin is more involved in the acute phase of inflammation and VCAM-1 and ICAM- 1 are more prominent in the chronic phase of the inflammatory process as has been demonstrated in other studies (1-5).

We hypothesize that the vascular outgrowth in the periphery of NSCLC is related to the vascular process of acute inflammation and likewise the activation status of endothelial cells in the center of the tumor may be similar to the status as present in chronic inflammation.

In a former study, we investigated the immunohistochernical staining pattern of cytokines and cytokine receptors on both NSCLC cells and immune cells of the host. Both NSCLC cells and monocytes/alveolar macrophages showed immunoreactivity for the cytokines TNF= $\alpha, \mathrm{IL}-6$ and IL-8, but only a minority of the mononuclear cells in tumor stroma were in an activated status (Staal, submitted). In general, mononuclear cells are responsible for the upregulation of adhesion molecules on endothelial cells and for the attraction of other immune cells to the site of inflammation (1-5). However, the tumor cells themselves could by secretion of chemotactic cytokines also be responsible for the upregulation of the adhesion molecules Eselectin and VCAM-1 on endothelial cells and attraction of immune cells (29-32). In addition, the tumor cells could promote angiogenesis by production of IL- 8 known as an angiogenic factor and thus favour the growth of the tumor (33). 
Next to endothelium, the expression of adhesion molecules on NSCLC cells and other cell types in the environment of the NSCLC cells was investigated. E-selectin expression was confined to endothelium only, while ICAM-1 and VCAM-1 were also expressed on NSCLC cells and other cell types. ICAM-1 positivity was demonstrated in $>75 \%$ of the NSCLC cells irrespective of tumor stage or histological type. Other studies, however, demonstrated differences in ICAM-1 positivity according to tumor histology. Ruco et al. (20) and Vitolo et al. (34) found more iCAM-1 expression on squamous cell carcinoma cells compared to adenocarcinoma cells, while Passlick et al. (35) found increased ICAM-1 expression in adenocarcinoma cells compared to squamous cell carcinoma cells of the lung. An explanation for these variations in outcome might be the use of different antibodies. Although controversy is present for the relationship between ICAM-1 staining and histologic type, the bottom line is that ICAM-1 has been demonstrated in several cases of NSCLC of all histologic types. Moreover ICAM-1 expression was also found on other types of tumor cells such as lymphomas, melanomas, pancreas and colon carcinomas (12,16,36-38) suggesting a similar pattern of activation in the different tumors. The inability to detect immunoreactivity for ICAM-I in some cases of NSCLC could be explained by reduced ICAM-I expression on these NSCLC cells. Further studies are needed to answer the meaning of reduction or absence of ICAM1 expression on tumor behavior in NSCLC patients.

VCAM-1 was expressed distinctly by NSCLC cells in 4 different cases. Sofar Ruco et al. (20) showed VCAM-1 expression in nasopharyngeal carcinomas, while other authors have not been able to demonstrate VCAM-1 expression on epithelial tumors. Recently Cunningham et al. demonstrated VCAM-1 expression on normal bronchial epithelium and isolated pneumocytes type II (39). The role of VCAM-I and ICAM1 expression on NSCLC cells might be explained by the active participation of NSCLC cells in inflammatory processes including the function of chemotaxis of mononuclear cells of the host.

The third group of cells investigated were the immune cells. The inflammatory infiltrate around the NSCLC consists predominantly of monocytes and lymphocytes. The latter are mainly T lymphocytes, while B-cells are a minor proportion as demonstrated in the present study and by others $(35,40)$. A typical membranous staining pattern for ICAM- 1 and VCAM-I expresșion was found on lymphocytes in tumor stroma. The staining patterns of ICAM-I and VCAM-1 on lymphocytes and in germinal centers were similar with staining patterns seen at sites of chronic inflammation in tonsils and reactive lymph nodes $(41,42)$. These data together support the viewpoint of an activated status of lymphocytes and germinal centers in the environment of the NSCLC cells. Tumor infiltrating monocytes did not express any immunohistochemical staining for the vascular cell adhesion molecules and reflect a reduced state of activation as supported by other studies $(1,8,9)$.

Fibroblasts were immunostained for ICAM-1 and VCAM-1. Human fibroblasts do not constitutively express ICAM-I in the lung, but ICAM-I expression is induced by 


\section{Chapter 6}

stimulation with IL- -, TNF- $\alpha$ or IFN- $\tau$ (8). The observed VCAM-1 expression on fibroblasts was also shown by Vitolo et al. in NSCLC (34). The increased expression of ICAM-I and VCAM-I on fibroblasts surrounding the tumor nests might promote the adhesion of different inflammatory cells to fibroblasts and could thus direct the immune cells to the tumor cells $(43,44)$.

In conclusion, the presence of both E-selectin, ICAM-1 and VCAM-1 on endothelial cells in tumor stroma supports the viewpoint of an active status of NSCLC vessels. This phenotypic pattern looks similar to the vascular component of inflammation. The presence of ICAM-I and VCAM-1 on NSCLC cells suggests a functional role in the process of chemotaxis for tumor cells as well. 


\section{References}

1. Springer TA. Adhesion receptors of the immune system. Nature 1990; 346:425-434

2. Bevilacqua MP. Endothelial-leukocyte adhesion molecule. Annu Rev Immunol 1993; 11:767-804

3. Mackay CR, Imhof BA. Cell adhesion in the immune system. Immunol Today 1993; 14:99-102

4. Pardi R, Inverardi L, Bender JR. Regulatory mechanisms in leukocyte adhesion: flexible receptors for sophisticated travelers. Immunol Today 1992; 13:224-230

5. Shimizu Y, Newman W, Tanaka Y. Shaw S. Lymphocyte interactions with endothelial cells. Immunol Today 1992; 13:106-112

6. Bevilacqua M, Stengilin S, Gimbrone MA, Seed B. ELAM-1: an inducible receptor for neutrophils related to complement regulatory proteins and lectins. Science 1989; 243:1160-1164

7. Leeuwenberg JFM, Jeunhomme TMAA, Buurman. WA. Characterisation of two monoclonal antibodies directed against an adhesion molecule on human endothelial cells. Transplantation Proc 1990: 22:1991-1993

8. Rothlein R, Czajkowski M, O'Neil MM, Marlin S, Mainolfi E, Merluzzi VR. Induction of intercellular adhesion molecule I on primary and continuous cell lines by pro-inflammatory cytokines. J Immunol 1988; 141:1665-1669

9. Rothlein R, Dustin ML, Marlin SD, Springer TA. A human intercellular adhesion molecule (ICAM-I) distinct from LFA-1. J Immunol 1986; 137:1270-1274

10. Osborn L, Hession C. Tizard R, Vassallo C, Luhowskyi R, Chi-Rosso C, Lobb R. Direct expression cloning of Vascular Cell Adhesion Molecule 1, a cytokine induced endothelial protein that binds to lymphocytes. Cell 1989; 59:1203-1211.

II. Rice GE, Munro JM. Bevilacqua M. Inducible cell adhesion molecule 110 is an endothelial receptor for lymphocytes - a CDI1/CD18-independent adhesion mechanism. J Exp Med 1990; 171:1369-1374

12. Thornhill MH, Haskard DO. IL-4 regulated endothelial cell activation by IL-1, tumour necrosis factor or IFN- $\gamma$. J Immunol 1990; 145:865-871

13. Dejana E, Bertocchi F, Bortolami MC, Regonessi A, Tonta A, Breviaro F, Giavazzi R. Interleukin I promotes tumor cell adhesion to cultured human endothelial cells. I Clin Invest 1988: $82: 1466-1470$

14. Rice GE, Gimbrone MAjr, Bevilacqua M. Tumor cell-endothelial interactions: increased adhesion of human melanoma cells to activated vascular endothelium. Am J Path 1988; 133:204 210

15. Bereta M, Bereta J, Cohen S, Zaifert K, Cohen MC. Effect of inflammatory cytokines of the adherence of tumor cells to endothelium in a murine model. Cell Immunol 1991; 136:263-277

16. Van Duinen CM, van den Broek LJCM, Vermeer BJ, Fleuren GJ, Bruyn JA. The distribution of cellular adhesion molecules in pigmented skin lesions. Cancer 1994; 73:2131-2139

17. Groves RW, Allen MH, Ross EL, Ahsan G, Barker JNWN, MacDonald DM. Expression of selectin ligands by cutaneous squamous cell carcinoma. Am J Path 1994; 143:1220-1225.

18. Johnson JP, Stade BG. Holzmann B, Schwable W. Riethmuller G. De novo expression of intercellular adhesion molecule in melanoma correlates with increased risk of metastasis. PNAS USA $1989 ; 86: 641-644$

19. Jonjic N, Martin-Padura I. Pollicino T. Bernasconi S, Jilek P. Bigotti A, Mortarini R, Anichini A, Parmiani G. Colotta F. Dejana E. Mantovani A. Natali PG. Regulated expression of vascular cell adhesion molecule I in human malignant melanoma. Am J Path 1992; 141:1323-1330

20. Ruco LP, Stoppacciaro A, Uccini S. Breviario F. Dejana E. Gallo A. De Vincentis M, Pileri S. Nicholls JM, Baroni CD. Expression of intercellular adhesion molecule-1 and vascular cell adhesion molecule-1 in undifferentiated nasopharyngeal carcinoma (lymphoepithelioma) and in malignant epithelial tumors. Hum Path 1994; 25:924-928 


\section{Chapter 6}

21. Staal-van den Brekel AJ, Dentener MA, Schols AMWJ, Buurman WA, Wouters EFM Increased resting energy expenditure and weight loss are related to a systemic inflammatory response in lung cancer patients. J Clin Oncol 1995; 13:2600-2605

22. Mountain CF. A new international staging system for lung cancer. Chest 1986; 89:225s-233s

23. Thornhill MH. Wellicome SM, Mahiouz DL, Lanchburry JSS, Kyang-Aung U, Haskard DO. Tumor Necrosis Factor combines with $\mathrm{IL}-4$ and IFN $-\tau$ to selectively enhance endothelial cell adhesiveness for $\mathrm{T}$ cells. The combination of vascular cell adhesion molecule- 1 dependent and independent binding mechanisms, J Immunol 1991; 146:592-598

24. SPSS/PC+ Statistics4.0 for the IBM.PC/XT/AT and PS/2, MJ Norusis /SPSS Inc, New York 1990

25. Folkman J, Cotran R. Relation of vascular proliferation to tumor growth. Int Rev Exp Path 1976; 16:207-248

26. Folkman J. Tumor angiogenesis. Adv Cancer Res $1985 ; 43: 175-203$

27. Bouck $N$. Tumor angiogenesis: the role of oncogenes and tumor suppressor genes. Cancer Cells 1990; 2:179-185

28. Jain RK. Determinants of tumour blood flow: A review. Cancer Res 1988; 48:2641-2658

29. Xing Z, Braciak T, Jordana M, Croitoru K, Graham FL, Gauldie J. Adenovirus-mediated cytokine gene transfer at tissue sites, overexpression of IL-6 induces lymphocytic hyperplasia in the lung. J Immunol 1994; 153:4059-4069

30. KunkeI SL, Standiford T, Kasahara K, Strieter RM. Interleukin-8: The major neutrophil chemotactic factor in the lung. Exp Lung Res 1991; 17:17-23

31. Baggiolini M, Walz A, Kunkel SL. Neutrophil-activating peptide-1/Interleukin 8, a novel cytokine that activates neutrophils. J Clin Invest 1989: 84:1045-1049

32. Rot A. Endothelial cell binding of NAP-1/IL-8: role in neutrophil emigration. Immunol Today $1992 ; 13: 291-294$

33. Smith D, Polverini $P$, Kunkel $S$, Orringer $M$, Whyte $R$, Burdick $M$, Wilke $C$, Strieter $R$. Inhibition of Interleukin 8 attenuates angiogenesis in bronchogenic carcinoma. J Exp Med 1994; 179: $1409-1415$

34. Vitolo D, Palmieri MB, Ruco LP, Rendina E, Bonsignore G, Baroni CD. Cytokine production and expression of adhesion molecules and integrins in tumor infiltrating lymphomononuclear cells of non-small cell carcinomas of the lung. Am J Path 1994; 145:322-329

35. Passlick B, Izbicki JR, Simmel S, Kubuschok B, Karg O, Habekost M, Thetter O, Schweiberer L. Pantel K. Expression of major histocompatibility class $\mathbf{I}$ and class II antigens and intercellular adhesion molecule- 1 on operable non-smaill cell lung carcinomas: frequency and prognostic significance. Eur J Cancer 1994: 30A:376-381

36. Tomita Y, Watanabe H, Kobayashi H. Nishiyama T, Tsuji S, Imai K, Abo T, Fujiwara M, Sato S. Expression of intercellular adhesion molecule-1 on transitional cell cancer, possible significance in immunity against tumor cells. Am J Path 1993: 143:191-198

37. Dippold W, Wittig B, Schwaeble W. Mayet W. Meyer zum Büschenfelde. Expression of intercellular adhesion molecule 1 (ICAM-1, CD54) in colonic epithelia! cells. Gut 1993; 34:1593-1597

38. Schwaeble W, Kerlin M, Meyer zum Büschenfelde, Dippold W. De novo expression of intercellular adhesion molecule I (ICAM-I, CD54) in pancreas cancer. Int J Cancer 1993; 53:328-333

39. Cunningham AC, Milne DS, Wilkes J, Dark JH, Tetley TD, Kirby JA. Constitutive expression of MHC and adhesion molecules by alveolar epithelial cells (type II pneumocytes) isolated from human lung and comparison with immunocytochemical findings. J Cell Sci 1994; 107:443-449

40. Whiteside TL, Jost LM, Herberman RB. Tumor infiltrating lymphocytes. Potential and limitations to their use for cancer therapy. Crit Rev Oncol Hematol 1992; 20:25-47

41. Koopman G. Parmentier HK, Schuurman HJ. Newman W. Meijer CJLM. Pals ST. Adhesion of 


\section{Adhesion molecule expression in NSCLC}

human B cells to follicular dendritic cells involves both the lymphocyte function-associated antigen 1/intercellular adhesion molecule 1 and very late antigen 4/vascular cell adhesion molecule 1 pathways. J Exp Med 1991; 173:1297-1304

42. Ree HJ, Khan AA, Elsakr M, Liau S, Teplitz C. Intercellular adhesion molecule-1 (ICAM-1) staining of reactive and neoplastic follicles. Cancer 1993; 71:2817-2822

43. Dustin ML, Rothlein R, Bhan AK, Dinarello CA, Springer T. Induction by IL I and Interferon$\tau$ : tissue distribution, biochemistry, and function of a natural adherence molecule (ICAM-1) J Immunol 1986; 137:245-254

44. Law SK. Antigen shedding and metastasis of tumour cells. Clin Exp Imm 1991; 85:1-2 



\title{
THE ENHANCED INFLAMMATORY RESPONSE IN NON-SMALL CELL LUNG CARCINOMA IS NOT REFLECTED IN THE ALVEOLAR COMPARTMENT
}

\begin{abstract}
The inflammatory response has been observed in cancer both locally and systemically. The aim of the present study was to investigate whether the alveolar compartment was involved in the inflammatory response in non-small cell lung carcinoma (NSCLC). Both inflammatory mediators in bronchoalveolar lavage fluid (BALF) and cytokines produced by alveolar macrophages (AM) were investigated. Twenty patients with newly detected NSCLC and 9 controll subjects were studied. BAL was performed in the affected lung as well as in the contralateral lung of NSCLC patients and only unilaterally in control subjects. Comparable results were demonstrated for the levels of the inflammatory mediators TNF- $\alpha$, Interleukin (IL)-6, IL-8, both soluble TNFreceptors and the soluble adhesion molecules E-selectin and Intercellular Adhesion Molecule (ICAM)-1 between the affected lung and the contralateral lung in the NSCLC population as well as between the NSCLC population and the control subjects. Moreover, no significant differences in cytokine profiles of AM were found between AM obtained from the affected lung and from the contralateral lung, respectively. These data suggest that the enhanced inflammatory state, as reported in plasma and in the interstitial compartment around the tumor cells in NSCLC before, is not reflected in the alveolar compartment in NSCLC patients.
\end{abstract}




\section{Introduction}

Neoplastic diseases induce profound changes in the mononuclear phagocyte system: both local and systemic inflammatory responses are observed in the presence of the tumor (1-7). The local inflammatory response is characterized by the accumulation of mononuclear cells in stroma around the tumor cells (1-7). The presence of inflammatory cells that produce cytokines such as TNF- $\alpha$, Interleukin (IL)- 6 and IL-8 can be seen as both advantageous and harmful for the tumor (8-10). The angiogenic properties of both TNF- $\alpha$ and IL- 8 can be favourable for the growth of the tumor (1113). However, the cytokines IL-6 and IL-8 attract other mononuclear cells that are known to interfere with tumor growth $(8,9)$. In addition, IL-6 is well known as an inducer of the protective acute phase response of the host (14). In a former study of our group, we showed the presence of immunohistochemical staining patterns for TNF- $\alpha$, IL-6, IL-8 and enhanced expression of both TNF-receptors in tissue samples obtained from resection specimens of non-small cell lung carcinoma (NSCLC) patients (submitted). These data combined with the enhanced expression of the adhesion molecules $E$-selectin, interecllular adhesion molecule (ICAM) 1 and vascular coll adhesion molecule (VCAM)-1 (15) reflect the presence of the local inflammatory response around the tumor cells in NSCLC.

We also observed the presence of the systemic inflammatory response in NSCLC. Enhanced levels of both soluble (s) TNF-receptors, the acute-phase proteins C-reactive protein (CRP) and LPS-binding protein (LBP), and sICAM-1 were demonstrated in plasma of patients with NSCLC (7). The soluble forms of both TNF-receptors, the adhesion molecules and both acute phase proteins are considered to reflect inflammatory activity (16-18). Metabolic disturbances were found to be related to the presence of these enhanced levels of inflammatory mediators in patients with NSCLC (7). Our data were supported by others who found the same relationship between metabolic disturbances and inflammatory parameters in patients with pancreas carcinoma and haematological malignancies (4-6).

In the present study, we investigated whether the inflammatory process in the interstitial comparment of the affected lung extends into the alveolar compartment of the lung in NSCLC. The bronchoalveolar lavage (BAL) is an important tool to assess the inflammatory state in the alveolar compartment of the lung. During different acute inflammatory reactions, cellular changes in BALF (influx of neutrophils or lymphocytes) occur and alveolar macrophages (AM), the major cellular component of the alveolar compartment, can be activated (19). Besides these cellular changes, the presence of an inflammatory state in the alveolar compartment is reflected by increased levels of the pro-inflammatory cytokines TNF- $\alpha$, IL- 6 and IL- 8 or soluble adhesion molecules in BALF as has been demonstrated in several pulmonary diseases (20-26). The aim of the present study was to investigate whether the alveolar compartment was involved in the inflammatory response in NSCLC. To this end the pro-inflammatory cytokines, both soluble TNF-receptors and soluble adhesion molecules were assessed 
in BALF and the production of cytokines by AM was determined in vitro. BALF obtained from the tumor site was compared with BALF obtained from the contralateral lung as well as with BALF obtained from control subjects.

\section{Subjects and methods}

\section{Patients and control subjects}

The characteristics of the study population are shown in Table 1. Twenty patients with primary NSCLC (12 patients with squamous cell carcinoma and 8 patients with adenocarcinoma) and 9 control subjects were included in the study. All patients had histologically documented tumors. Fourteen tumors were located in the upper lobes, 3 tumors were located in the middle lobe or lingula and 3 tumors were located in the lower lobes. All tumors were located peripherally. All patients and control subjects were current smokers $(n=18)$ or had stopped smoking during the last 6 months $(n=11)$.

Table 1: Characteristics of the study population

\begin{tabular}{lll}
\hline & $\begin{array}{l}\text { NSCLC } \\
(\mathrm{n}=20)\end{array}$ & $\begin{array}{l}\text { Control subjects } \\
(\mathrm{n}=9)\end{array}$ \\
\hline male/female & $14 / 6$ & $7 / 2$ \\
age (y) & $63 \pm 2$ & $55 \pm 3$ \\
years of smoking & $43 \pm 3$ & $33 \pm 4$ \\
FEV, (\%) & $88 \pm 5$ & $95 \pm 4$ \\
IVC (\%) & $105 \pm 3$ & $103 \pm 5$ \\
Tumor stage (n) & 12 & \\
Stage I and II & 5 & \\
Stage IIIA & 1 & \\
Stage IIIB & 2 & \\
Stage IV & & \\
\hline
\end{tabular}

Data are expressed as mean \pm standard error of the mean. No significant differences have been found berween the lung cancer population and control subjects, $F E V_{t}=$ forced expiratory volume in I second, $I V C=$ inspiratory vital' capacify, $n=$ number 


\section{Chapter 7}

The patients had not been treated with chemotherapy, radiotherapy or with corticosteroids. The new international staging system for lung cancer was used to assess tumor stage (27). Control subjects were selected out of the smoking patient population who underwent a bronchoscopy for several reasons, but finally no pathology was demonstrated.

The study was approved by the medical ethical committee of the University Hospital of Maastricht. Written informed consent was obtained from all patients and control subjects.

\section{Bronchoalveolar lavage}

BAL was performed during fibreoptic bronchoscopy. After premedication (atropine 0.5 $\mathrm{mg} \mathrm{i.m.} \mathrm{and} \mathrm{diazepam} 10 \mathrm{mg}$ p.o. $1 \mathrm{~h}$ before bronchoscopy) and local anaesthesia of the larynx and bronchial tree (lidocaine $10 \%$ ), a flexible, fibreoptic bronchoscope was introduced and placed in wedge position in the segment with tumor localization as well as in either the lingula or the middle lobe of the contralateral lung. Accordingly, BAL was performed by siandardized washing of these segments. Four aliquots of $50 \mathrm{ml}$ sterile saline $(0.9 \% \mathrm{NaCl})$ at $37^{\circ} \mathrm{C}$ were used for each lung. In control subjects, BAL was performed unilaterally either in the lingula or right middle lobe. The first aliquot of recovered BALF was discarded and the last 3 aliquots were pooled. BALF was collected in polypropylene tubes (Greiner, Alphen a/d Rijn, the Netherlands) and kept on ice in order to minimize AM adherence. Cytospin slides of BALF cells were stained with May-Grünwald-Giemsa (MGG; Merck, Darmstadt, Germany) for cell differentiation. At least 1.000 cells were counted. Cytologic examination of the BALF revealed no malignant cells. Next cells were separated from BALF by centrifugation at $500 \times \mathrm{g}$ for 5 minutes after cell differentiation. Cell free BALF was filtered through a layer of gauze to remove mucus strands. BALF was concentrated by lyophilization and resuspended in distilled water to $10 \%$ of the original volume before determinations and stored at $-70^{\circ} \mathrm{C}$ until analysis. No significant positive bacterial cultures were found in any of the BALF samples investigated. Blood was obtained by venepuncture and collected in evacuated blood collection tubes (Sherwood Medical, St Louis, MO) containing Heparin ${ }^{*}$ (Leo Pharmaceutical Products B.V., Weesp, The Netherlands).

\section{Alveolar macrophages recovery and culture}

After centrifugation, cells obtained from BALF were washed twice and filtered through a modified transfusion system (N.P.B.I., the Netherlands). Cells were cultured in medium consisting of RPMI 1640 (Gibco, Paisley, U.K.) supplemented with antibiotics and $10 \%$ bovine calf serum (Hyclone, Logan, UT). Bovine calf serum was heated at $56{ }^{\circ} \mathrm{C}$ for 30 minutes before storage at $4{ }^{\circ} \mathrm{C}$ and contained $<5 \mathrm{pg} / \mathrm{ml}$ endotoxin as determined in the Limulus assay (Coatest, Kabi Vitrum, Stockholm, Sweden). Cells, consisting for more than 90 percent of $\mathrm{AM}$, were cultured at a number of $5.0 * 10^{5} / \mathrm{ml}$ 
in 24-wells plates (Costar, Cambridge, MA) and stimulated in duplo with LPS (E. Coli 055:B5, Sigma, St. Louis, MO); in concentrations of $0,10 \mathrm{ng} / \mathrm{ml}, 1 \mu \mathrm{g} / \mathrm{ml}$ and 100 $\mu \mathrm{g} / \mathrm{ml}$. After $20 \mathrm{~h}$ of stimulation, which was found to be the optimum for TNF- $\alpha$, il -6 and IL- 8 production by $\mathrm{AM}$ as determined (data not shown), plates were centrifuged at $500 \times \mathrm{g}$,, supernatant was collected and stored at $-70{ }^{\circ} \mathrm{C}$ until analysis.

\section{Inflammatory mediators}

Inflammatory mediators were assessed using sandwich ELISA as described previously: (28-32). In short, the TNF- $\alpha$ ELISA consisted of $61 \mathrm{E} 71$ as coating $\mathrm{mAb}$ and polyclonal rabbit anti-human TNF- $\alpha$ Abs. TNF- $\alpha$ could be detected with a lower detection limit of $20 \mathrm{pg} / \mathrm{ml}$. For measurement of sTNF-R55 and sTNF-R75, MAbs MR1-1 and MR2-2 were used respectively for coating. Specific biotin labelled polyclonal rabbit anti-human sTNF-R IgG were used as detector reagents. The detection limit of both assays was 50 $\mathrm{pg} / \mathrm{ml}$. IL- 6 was caught by $\mathrm{mAb} 5 \mathrm{EI}$ and detected by polyclonal rabbit anti-human II- 6 Abs. IL- 6 could be detected with a lower detection limit of $10 \mathrm{pg} / \mathrm{ml}$. The IL- 8 ELISA consisted of HM5 as coating mAb and biotinylated polyclonal rabbit anti-human IL-8 Abs. The detection limit of IL- 8 was $20 \mathrm{pg} / \mathrm{ml}$. For sICAM-I ELISA, mAb HM 2 was used for coating. Biotinylated mAb HM. I was used for detection. The detection limit of the assay was $400 \mathrm{pg} / \mathrm{ml}$. For sE-selectin ELISA, plates were coated with $\mathrm{mAb}$ ENA1 and biotin labelled mAb ENA2 was used as detector reagent. Since binding of ENA1 and ENA2 to sE-selectin is Ca-dependent, $4 \mathrm{mM} \mathrm{Ca}^{++}$and $2.5 \mathrm{mM} \mathrm{Mg}^{++}$were added to the buffers in this assay. The detection limit of the assay was $1 \mathrm{ng} / \mathrm{ml}$.

Immuno assay plates (Nunc-Immuno Plate Maxisorp, Roskilde, Denmark) were used for the ELISA assays. Biotinylated samples were detected with streptavidin-peroxidase conjugate (Dako, Glostrup, Denmark), while peroxidase-conjugated goat anti-rabbit IgG (Jackson Immunoresearch, West Grove, PA) was used in the TNF- $\alpha$ and IL-6 ELISA. TMB (3,3',5,5'-tetramethylbenzidine, Kirkegaard \& Perry Lab., Gaithersburg, MD) was used as a substrate. Photospectometry $(450 \mathrm{~nm})$ was performed using a micro ELISA autoreader.

\section{Biochemical parameters}

Serum urea and albumin have been determined on a Synchron CX-7 analyser (Beckman Instruments Inc, USA, California) using test kits from Beckman Instruments Inc. For the determination of urea in both serum and BALF an enzymatic conductivity rate method (testkit 443350) was used. For the determination of serum albumin the bromcresol purple method (testkit 442765) was used. In BALF albumin was determined on an Array 360 System for immunochemistry (USA, California), using a microalbumin method (testkit P/N 441450). BALF total protein was measured with the pyrgallol method described by Watanabe et al. (33). Lactate dehydrogenase (LDH) activity was measured by an enzymatic rate method, using pyruvate as a substrate. 
Alkaline phosphatase (ALP) was measured by an enzymatic rate method using pnitrophenylphosphate as a substrate.

\section{Statistics}

Data are expressed as mean \pm standard error of the mean (SEM) and, if appropriate, as median with range. Groups were statistically compared using analysis of variance or the Mann-Whitney $U$ test. The BALF/blood ratios were calculated for albumin and urea in order to get insight in possible leakage between the alveolar compartment and the blood compartment. BALF/blood ratios for albumin and urea were calculated as follows: BALF/blood ratio for albumin = [albumin level in BALF]/[albumin level in blood]. The same calculation was used for urea. Probability values less than 0.05 were considered to be significant. The statistical analyses were performed using the SPSS/PC +4.0 package (34).

Table 2: Cellular profile of the bronchoalveolar lavage fluid in NSCLC and control subjects

\begin{tabular}{llll}
\hline & \multicolumn{2}{c}{$\begin{array}{c}\text { NSCLC patients } \\
(\mathrm{n}=20)\end{array}$} & $\begin{array}{c}\text { Control subjects } \\
(\mathrm{n}=8)\end{array}$ \\
\hline & Tumor site & Contralaterai & $77.6 \pm 8.3$ \\
\hline recovery $(\mathrm{ml})$ & $60.3 \pm 4.5$ & $71.6 \pm 5.1$ & $18.5 \pm 4.2$ \\
Total cell count $\left(* 10^{4} / \mathrm{ml}\right)$ & $33.6 \pm 5.9$ & $31.8 \pm 5.3$ & $91.7 \pm 3.9$ \\
AM $(\%)$ & $89.3 \pm 2.7$ & $91.1 \pm 2.3$ & $1.7 \pm 0.8$ \\
PMN $(\%)$ & $2.5 \pm 0.9$ & $1.5 \pm 0.4$ & $6.5 \pm 3.2$ \\
Lymphocytes $(\%)$ & $8.0 \pm 2.3$ & $7.8 \pm 2.3$ & \\
\hline
\end{tabular}

Data are expressed as mean \pm standard error of the mean, AM = Alveolar Macrophages, PMN $=$ Polymorphonuclear neutrophils

\section{Results}

First the systemic and local inflammatory response was assessed in our patient population. Thirteen out of the 20 NSCLC patients demonstrated an acute phase response (CRP level: $20 \pm 18 \mu \mathrm{g} / \mathrm{ml}$, range $7-57 \mu \mathrm{g} / \mathrm{ml}$ ), while no enhanced levels of CRP were detected in control subjects (CRP $<5 \mu \mathrm{g} / \mathrm{ml}$ ) (7). The local inflammatory response could be investigated in the resection materials of 12 out of the 20 NSCLC patients as described in previous studies ( 15 ,submitted). An accumulation of mononuclear cells around the tumor cells was demonstrated in all specimens investigated. These findings indicate the presence of a local inflammatory response. 
Table 3: Non-cellular constinuents of the bronchoalveolar lavage fluid in NSCLC and control subjects

\begin{tabular}{llll}
\hline & \multicolumn{2}{c}{$\begin{array}{c}\text { NSCLC patients } \\
(\mathrm{n}=20)\end{array}$} & $\begin{array}{c}\text { Control subjects } \\
(\mathrm{n}=9)\end{array}$ \\
& Tumor site & Contralateral & \\
\hline Albumin $(\mathrm{mg} / \mathrm{l})$ & $33.5 \pm 4.2$ & $27.6 \pm 3.6$ & $30.3 \pm 4.5$ \\
& $27.0(13.0-75.0)$ & $22.0(8.0-58.0)$ & $29.0(11.0-59.0)$ \\
Tot.Protein (mg/1) & $50 \pm 10$ & $40 \pm 10$ & $40 \pm 10$ \\
& $40(10-180)$ & $30(10-80)$ & $30(20-80)$ \\
Urea (mmol/1) & $0.46 \pm 0.05$ & $0.48 \pm 0.04$ & $0.37 \pm 0.07$ \\
& $0.50(0.10-0.70)$ & $0.50(0.10-0.90)$ & $0.40(0.10-0.70)$ \\
BALF/blood ratio & $0.09 \pm 0.01$ & $0.07 \pm 0.01$ & $0.08 \pm 0.01$ \\
for Albumin & $0.07(0.03-0.21)$ & $0.06(0.02-0.15)$ & $0.07(0.03-0.15)$ \\
BALF/blood ratio & $0.09 \pm 0.01$ & $0.09 \pm 0.01$ & $0.08 \pm 0.02$ \\
for Urea & $0.08(0.01-0.18)$ & $0.08(0.02-0.19)$ & $0.06(0.02-0.19)$ \\
\hline
\end{tabular}

Data are expressed as mean \pm standard error of the mean; the median is given with the range in parentheses: No significant differences were found between the different sites investigated. Tot. Protein $=$ Total Protein, $B A L F=$ bronchoalveolar lavage fluid

In order to investigate the inflammatory response in the alveolar compartment in NSCLC, the cellular profile of BALF was assessed (Table 2). The data show that the total cell count and the differential cell count did not show significant differences between the BALF obtained from patients suffering from NSCLC and control subjects. In line with these data, we observed also no differences in cellular profile between the affected lung and the contralateral lung of the NSCLC patients. In case of damage to the alveolar-capillar membrane and edema, one would expect increased levels of the non-cellular constituents total protein, albumin and urea in BALF. Equal levels of the non-cellular constituents were demonstrated in BALF obtained from the lung cancer population and from control subjects (Table 3). Moreover, the levels were also similar between the affected lung and the contraiateral lung in NSCLC patients. In order to assess the degree of dilution of BALF, BALF/blood ratios for albumin and ureum were determined. The data showed that these ratios were similar for both the tumor lung and contralateral lung and for the lung cancer population and control subjects. No differences in degree of dilution could therefore be detected among the three groups. Next the levels of inflammatory mediators in BALF of both NSCLC patients and control subjects were determined. The data are summarized in Table 4. Comparable results were found for both soluble TNF-receptors, sICAM-1, sE-selectin and the proinflammatory cytokines IL-6 and IL-8 between patients suffering from NSCLC and control subjects. TNF- $\alpha$ was not detectable in any of the BALF samples investigated (data not shown). Only small amounts of sTNF-R55, sE-selectin and IL-6 were present in BALF. The mean levels were near the detection limit of the ELISA which explains 
Table 4: Inflammatory mediators in the bronchoalveolar lavage fluid

\begin{tabular}{llll}
\hline & \multicolumn{2}{c}{$\begin{array}{c}\text { NSCLC patients } \\
(\mathrm{n}=20)\end{array}$} & \multicolumn{1}{c}{$\begin{array}{c}\text { Control subjects } \\
(\mathrm{n}=9)\end{array}$} \\
& Tumor Site & Contralateral & \\
\hline sTNF-R55 (ng/ml) & $0.08 \pm 0.02$ & $0.08 \pm 0.02$ & $0.07 \pm 0.03$ \\
& $0.04(0.01-0.40)$ & $0.04(0.01-0.48)$ & $0.03(0.01-0.27)$ \\
sTNF-R75 (ng/ml) & $0.37 \pm 0.07$ & $0.30 \pm 0.05$ & $0.21 \pm 0.05$ \\
& $0.32(0.01-1.10)$ & $0.26(0.02-0.87)$ & $0.11(0.07-0.48)$ \\
sICAM-1 (ng/ml) & $103.6 \pm 19.6$ & $96.0 \pm 19.4$ & $120.3 \pm 44.0$ \\
& $66.9(19.0-326.0)$ & $87.0(20.6-410.2)$ & $94.0(28.0-462.0)$ \\
sE-selectin (ng/ml) & $0.12 \pm 0.01$ & $0.10 \pm 0.10$ & $0.10 \pm 0.02$. \\
& $0.10(0.10-0.31)$ & $0.10(0.10-0.14)$ & $0.10(0.10-0.25)$ \\
IL-6 (ng/ml) & $0.04 \pm 0.01$ & $0.04 \pm 0.01$ & $0.04 \pm 0.01$ \\
& $0.05(0.01-0.13)$ & $0.03(0.01-0.11)$ & $0.04(0.02-0.08)$ \\
IL-8 (ng/ml) & $0.36 \pm 0.16$ & $0.14 \pm 0.03$ & $0.26 \pm 0.11$ \\
& $0.15(0.01-3.1)$ & $0.11(0.02-0.39)$ & $0.11(0.01-0.93)$ \\
\hline
\end{tabular}

Data are expressed as mean \pm standard error of the mean; the median is given with the range in parentheses. No significant differences were found berween the different sites investigared. $s=$ soluble, TNF-R55 $=$ TNF-receptor 55, ICAM-I $=$ Intercellular Adhesion Molecule-I

the narrow range observed for these parameters. In accordance with other studies, larger ranges were detected for the other inflammatory mediators. In order to investigate whether tumor characteristics could influence levels of inflammatory mediators in BALF, patients were divided according to tumor stage or histology of the tumor. These analyses revealed no differences in levels of inflammatory mediators (data not shown).

The local inflammatory response was further investigated by measuring LDH and ALP in BALF as indicators of cell death and injury $(35,36)$. Mean levels for LDH in the lung cancer population were $28 \pm 3 \mathrm{U} / \mathrm{l}$ in the affected lung and $29 \pm 2 \mathrm{U} / \mathrm{l}$ in the contralateral lung while mean level for LDH in control subjects was $31 \pm 4 \mathrm{U} / 1$ (normal range 10-50 U/1). ALP was neither detectable in BALF of patients suffering from NSCLC nor in BALF of control subjects (normal range 0-25 U/I).

Finally, the ability of AM to produce cytokines in vitro was determined. AM were obtained from both the affected and the contralateral lung of the lung cancer population and were activated in culture with different concentrations of LPS. Comparable results were demonstrated in cytokine production between AM obtained from the tumor lung and AM obtained from the contralateral lung either with or without stimulation of LPS (Figure 1). 

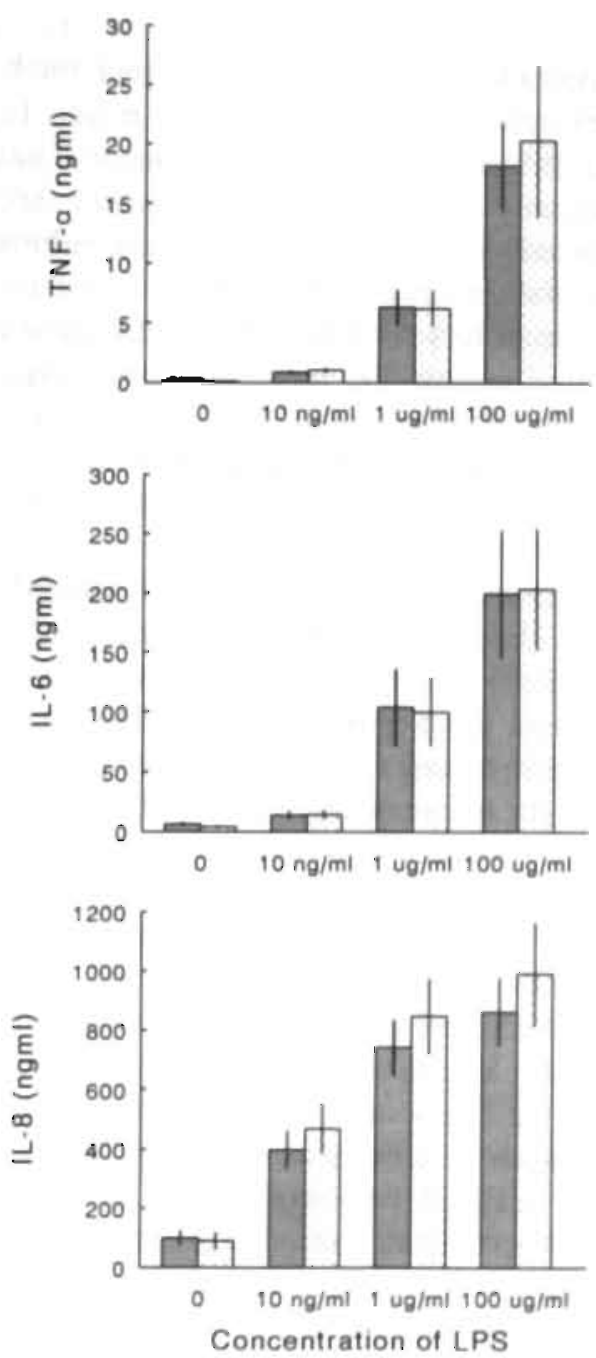

$\square$ contralateral $\square$ tumor

Legend to figure I

Stimulation experiments of alveolar macrophages subdivided according to cytokine production. Upper figure: TNF- $\alpha$ production by alveolar macrophages after stimulation with $0,10 \mathrm{ng} / \mathrm{ml}, I \mathrm{\mu g} / \mathrm{ml}$ and 100 $\mu \mathrm{g} / \mathrm{ml}$ LPS, middle figure: IL-6 production by alveolar macrophages after stimulation with LPS, lower figure: IL-8 production by alveolar macrophages after stimulation with LPS. Results are expressed as mean \pm standard error of the mean 


\section{Discussion}

Bronchoalveolar lavage is nowadays a widely accepted tool for both diagnostic and research purposes to investigate the alveolar compartment. Enhanced levels of inflammatory mediators in BALF reflect the inflammatory state in the alveolar compartment of several pulmonary diseases such as pulmonary sarcoidosis, idiopathic pulmonary fibrosis, HIV-infected patients, chronic obstructive pulmonary disease, adult respiratory distress syndrome and pneumoconiosis (20-26). Previously we demonstrated increased plasma levels of inflammatory mediators in NSCLC patients (7). In addition, a local inflammatory response around the tumor cells was demonstrated in tissue samples obtained from resection specimens of NSCLC patients (15, submitted). In the present study, however, the levels of inflammatory mediators in BALF of NSCLC patients were comparable with those in control subjects. In addition, no differences in levels of inflammatory mediators in BALF and cytokine profiles of AM were found between the affected and the contralateral lung in patients with NSCLC. Our data are in contrast with Arias-Diaz et al. (37) who found increased levels of TNF- $\alpha$ and IL-6 in BALF obtained from 22 patients with bronchogenic squamous carcinoma. Plumb et al., however, supported our data (38): they reported no differences in cytokine profiles (IL- 1 and TNF- $\alpha$ ) in BALF between lung cancer patients and control subjects. Further we observed that the levels of the chemotactic cytokines IL-6 and IL-8 in BALF were similar between the NSCLC patients and control subjects. Since the expression of both TNF-receptors on NSCLC cells was enhanced (submitted), both sTNF-receptors were determined in BALF. Comparable results for both sTNF-receptors were demonstrated in BALF obtained from the tumor lung and the contralateral lung as well as from the lung of control subjects. In addition, we determined the soluble adhesion molecules Eselectin and ICAM-1 in BALF. An enhanced expression of these adhesion molecules was observed in NSCLC (15). The soluble forms of these adhesion molecules are considered to represent inflammatory activity as well (18). No differences were found for $\mathrm{SE}$-selectin and SICAM-1 in BALF between NSCLC and controls either.

The present study did not demonstrate an enhanced inflammatory state in the alveolar compartment of NSCLC patients. These data suggest that no damage of the alveolar membrane was present and, as a consequence, no leakage of inflammatory mediators occurred. This hypothesis is supported by the absence of signs of cell damage in BALF: no enhanced levels of LDH or ALP, known as parameters for cell damage or cell death, were detected. Comparable results were found in cellular distribution of BALF samples obtained from the 3 groups. Moreover, no malignant cells were found in BALF obtained from the tumor site.

Another explanation for the absence of an inflammatory state in the alveolar compartment might be that the tumor itself or the infiltrating cells produce immunosuppressive molecules that affect the production of cytokines by AM in the alveolar compartment. Immunosuppressive molecules such as IL-10, Nitric Oxide, Prostaglandin $E_{2}$ and sTNF-receptors are produced by tumor cells and macrophages in the 
environment of the tumor (39-45). TNF-receptors can have an immunosuppressive function by binding to biologically active TNF- $\alpha$. However, we observed an enhanced expression of both TNF-receptors in the interstitial compartment, but not in the alveolar compartment. Increased levels of nitrite/nitrate and Prostaglandin $E_{2}$ have been demonstrated in BALF of patients with primary lung cancer $(37,45)$.

Beside these possible explanations for the absence of an enhanced inflammatory state (as reflected by BALF analysis) in the alveolar compartment next to the tumor, smoking behavior needs to be taken into account as well. Smoking can affect the total and differential cell count of the BALF and changes the viability and cytokine production of AM. Reduced production of TNF- $\alpha$, IL- IB and IL- 6 by AM has been demonstrated in smokers by several authors (46-48). In the present study all patients and control subjects were smokers or stopped smoking recently and no significant differences were detected in smoking behavior between patients suffering from NSCLC and control subjects.

In conclusion, comparable results in levels of inflammatory mediators in BALF were found between NSCLC patients and control subjects. In addition, no differences in cytokine profiles of $\mathrm{AM}$ were found between the affected lung and the contralateral lung in patients with NSCLC. These data suggest that the enhanced inflammatory state, as reported in plasma and in the interstitial compartment around the tumor cells in NSCLC before, is not reflected in the alveolar compartment in NSCLC patients 


\section{Chapter 7}

\section{References}

1. Mantovani A, Bottazzi B, Colotta F, et al. The origin and function of tumor-associated macrophages. Immunol Today 1992; 13:265-70

2. Vitolo D, Zerbe T, Kanbour A, et al. Expression of mRNA for cytokines in tumor-infiltrating mononuclear cells in ovarian adenocarcinoma and invasive breast cancer. Int $J$ Cancer 1992; $51: 573-80$

3. Vitolo D, Palmieri MB, Ruco LP, et al. Cytokine production and expression of adhesion molecules and integrins in tumor infiltrating lymphomononuclear cells of non-small cell carcinomas of the lung. Am J Pathology 1994; 145:322-29

4. Dosquet C. Schaetz A. Faucher C, et al. Tumour necrosis factor- $\alpha$, Interleukin-1B and Interleukin- 6 in patients with renal cell carcinoma. Eur J Cancer 1994; 30A:162-67

5. Falconer SJ, Fearon $\mathrm{KCH}$, Plester CE, et al. Cytokines, the acute phase response and resting energy expenditure in cachectic patients with pancreatic cancer. Ann Surg 1994; 219:325-31

6. Denz H, Orth B. Weiss G, et al. Serum soluble tumour necrosis factor receptor 55 is increased in patients with haematological neoplasia and is associated with immune activation and weight loss. Eur J Cancer 1993; 29a:2232-35

7. Staal-van den Brekel AJ, Dentener MA, Schols AMWJ, et al. Increased resting energy expenditure and weight loss are related to a systemic inflammatory response in lung cancer patients. J Clin Oncol 1995: 13:2600-05

8. Xing Z, Braciak T, Jordana M, et al. Adenovirus-mediated cytokine gene transfer at tissue sites, overexpression of IL-6 induces lymphocytic hyperplasia in the lung. J Immunol 1994; 153:4059-69

9. Kunkel SL, Standiford T, Kasahara K, et al. Interleukin-8: The major neutrophil chemotactic factor in the lung. Exp Lung Res 1991; 17:17-23.

10. Strieter RM, Remick DG, Lynch JP, et al. Differential regulation of Tumor Necrosis Factor-aipha in human alveolar macrophages and peripeheral blood monocytes: a cellular and molecular analysis. Am J Respir Cell Mol Biol 1989; 1:57-63

11. Frater-Schröder M, Risau W, Hallmann R, Gautschi P, Böhlen P: Tumor necrosis factor type $\alpha$, a potent inhibitor of endothelial cell growth in vitro, is angiogenic in vivo. Proc. Natl. Acad. Sci. 1987: $84: 5277-81$

12. Leibovich SJ, Polverini PJ, Shepard HM, Wiseman DM. Shively V. Nuseir N: Macrophageinduced angiogenesis is mediated by tumour necrosis factor- $\alpha$. Nature 1987; 329:630-32.

13. Smith DR, Polverini PJ. Kunkel SL, Orringer MB, Whyte RI, Burdick MD, Wilke CA, Strieter RM: Inhibition of Interleukin 8 attenuates angiogenesis in bronchogenic carcinoma. J Exp Med 1994: 179:1409-15

14. Heinrich PC. Castell JV. Andus T: Interleukin 6 and the acute phase response. Biochem I 1990; 265:621-36

15. Staal-van den Brekel AJ, Thunnissen FBJM, Buurman WA. Wouters EFM. Expression of Eselectin, intercellular adhesion molecule (ICAM)-I and vascular cell adhesion molecule (VCAM)-I in non-small cell lung carcinoma. Virchows Archiv 1996, 428;21-27

16. Tartaglia L, Goeddel DV. Two TNF-receptors. Immunol Today 1992; 13:151-53

17. Springer TA. Adthesion receptors of the immune system. Nature 1990; 346:425-34

18. Mackay CR. Imhof BA. Cell adhesion in the immune system. Immunol Today 1993; 13:224-30

19. Sibille Y, Reynolds HY. Macrophages and polymorphonuclear neutrophils in lung defense and injury. Am Rev Respir Dis 1990; 141:471-501

20. Hyers TM. Tricomi SM. Dettenmeier PA, et al. Tumor Necrosis Factor levels in serum and bronchoalveolar lavage fluid of patients with the adult respiratory distress syndrome. Am Rev Respir Dis 1991; 144:266-71 
21. Ishii Y, Kitamura S. Elevated levels of soluble ICAM-I in serum and BAL fluid in patients with active sarcoidosis. Chest 1995; 107:1636-40

22. Twigg HL. Bronchoalveolar lavage fluid in HIV-infected patients, "cytokine soup". Chest 1993; 104:659-60

23. Vanhée D, Gosset P. Boitelle A, et al. Cytokines and cytokine network in silicosis and coal workers' pneumoconiosis. Eur Respir J 1995; 8:834-42

24. Millar AB, Miller RF, Foley NM, et al. Production of Tumor Necrosis Factor- $\alpha$ by blood and lung mononuclear phagocytes from patients with human immunodefi-ciency virus-related lung disease. Am J Respir Cell Mol Biol 1991; 5:144-48

25. Rise GC, Larsson S, Löfahl CG, et al. Circulating cell adhesion molecules in bronchial lavage and serum in COPD patients with chronic bronchitis. Eur Respir J 1994; 7:1673-77

26. Du Bois RM, Hellewell PG. Hemingway I, et al. Soluble cell adhesion molecules ICAM-1, ELAM1 and VCAM-1 are present in epithelial lining fluid in patients with interstitial lung disease. Am Rev Respir Dis 1992; 145:a 190-95

27. Mountain CF. A new international staging system for lung cancer. Chest 1986; 89:225s-33s.

28. Engelberts I, Möller A, Schoen GJM, et al. Evaluation of measurement of human TNF in plasma by ELISA. Lymphokine and cytokine Res 1991; 10:69-76

29. Leeuwenberg JFM, Jeunhomme GMMA, Buurman WA. Slow release of soluble TNF-receptors by monocytes in vitro. J Immunology 1994; 152:4036-43

30. Leeuwenberg JFM, Smeets EF, Neefjes JJ, et al. E-selectin and intercellular adhesion molecule-1 are relased by activated human endothelial cells in vitro. Immunology 1992; 77:543-49

31. Dentener MA, Bazil V. Von Asmuth EJU, et al. Involvement of CDI4 in lipopolysaccharideinduced Tumor Necrosis Factor- $\alpha$, Interleukin- 6 and Interleukin- 8 release by human monocytes and alveolar macrophages. J Immunol 1993; 150:2885-91

32. Bouma MG, Stad RK, v.d. Wildenberg FAJM, et al. Differential regulatory effects of adenosine on cytokine release by activated human monocytes. J Immunol 1994; 153:4159-68

33. Watanabe N, Kamei S, Ohkuba A, et al. Urinary protein as measured with a pyrogallol-molybdate complex, manually and in a Hitachi 726 automated analyzer. Clin Chem 1986; 32:1551-54

34. SPSS/PC + Statistics 4.0 for the IBM.PC/XT/AT and PS/2, M.J. Norusis/ SPSS Inc, New York 1990

35. Hoffman RM, Rogers RM. Serum and lavage lactate dehydrogenase isoenzymes in pulmonary alveolar proteinosis. Am Rev Respir Dis 1991; 143:42-46

36. Henderson RF. Use of bronchoalveolar lavage to detect lung damage. Environmen-tal health perspectives 1984; 56:115-29

37. Arias-Díaz J, Vara E. Torres-Melero J, et al. Nitrite/nitrate and cytokine levels in bronchoalveolar lavage fluid of lung cancer patients. Cancer 1994; 74: 1546-51

38. Plumb M, Funahashi A, LeFever A. Tumor Necrosis Factor and Interleukin-1 are not reliable tumor mạkers in bronchoalveolar lavage fluid (BALF). Am J Respir Crit Care Med' 1995; 151:A280

39. Vercammen $\mathrm{C}$, Ceuppens JL. Prostaglandin $\mathrm{E}_{2}$ inhibits human T-cell proliferation after crosslinking of the CD3-Ti complex by directly affecting T cells at an early step of the activation process. Cell Immunol 1987: 104:24-31

40. Moore KW. O'Garra A. de Waal Malefyt R, et al. Interleukin 10. Annu Rev Immunol 1993; 11:165-90

41. Alleva DG, Burger CJ, Elgert KD. Increased sensitivity of tumor-bearing host macrophages to Interleukin-10: a counter-balancing action to macrophage mediated suppression. Oncology Res $1994 ; 6: 219-28$

42. Hibbs JB, Taintor RR, Vavrin Z, et al. Nitric oxide: a cytotoxic-activated macrophage effector molecule. Biochem Biophys Res Commun 1988; 157:87-94 


\section{Chapter 7}

43. Gordon C, Wofsy D. Effects of recombinant murine tumor necrosis factor- $\alpha$ on immune function. J Immunol 1990; 144:1753-58

44. Young MR, Knies $\mathrm{S}$. Prostaglandin $\mathrm{E}_{2}$ production by Lewis Lung carcinoma: mechanisms for tumor establishment in vivo. J Natl Cancer Inst 1984; 72:919-22

45. Funuhasho A, Harland RW, LeFever A. Association of increased prostaglandin $E_{2}$ content in bronchoalveolar lavage fluid and intrathoracic malignancy. Chest 1994; 106:166-72

46. Yamaguchi $E$, Itoh $A$, Furuya $K$, et al. Release of tumor necrosis factor- $\alpha$ from human alveolar macrophages is decreased in smokers. Chest 1993; 103:479-83

47. Sauty A, Mauel J, Philippeaux MM, et al. Cytostatic activity of alveolar macrophages from smokers and nonsmokers: role of Interleukin-1B, Interleukin-6, and Tumor Necrosis Factor- $\alpha$. Am J Respir Cell Mol Biol 1994; 11:631-37

48. Burke WMJ, Roberts CM, Bryant DH, et al. Smoking-induced changes in epithelial lining fluid volume, cell density and protein. Eur Respir J 1992; 5:780-84 


\title{
Chapter 8
}

\section{ENERGY BALANCE IN NON-SMALL CELL LUNG CANCER PATIENTS BEFORE AND AFTER SURGICAL RESECTION OF THE TUMOR}

\begin{abstract}
The purpose of this study was to investigate whether surgical removal of the tumor influences energy balance, body weight and body composition of lung cancer patients. In 53 non small cell lung cancer (NSCLC) patients resting energy expenditure (REE; ventilated hood), energy intake (EI; diet history), body weight and body composition (fat free mass (FFM); bioelectrical impedance analysis) were determined before tumor resection. In 39 (out of 53) patients REE, EI, body weight and body composition were also measured 3,6 and 12 months after tumor resection.

Sixty-eight percent (36 out of 53) of the patients were hypermetabolic. Fourteen patients were excluded from the repeated measurements. Patients with curative tumor resection $(n=30)$ showed an increase in body weight over a one year period, in contrast to patients with tumor recurrence $(\mathrm{n}=9)$ who lost weight $(+3.5$ versus $-3.6 \mathrm{~kg}, \mathrm{p}<$ 0.005 ). The weight gain consisted predominantly of fat mass (FM), while the weight loss consisted for more than half of FFM. Body weight was increased in hypermetabolic $(n=20)$ as well as in normometabolic patients $(n=10)$ one year after successful removal of the tumor. However, while EI/REE was significantly increased in hypermetabolic patients (106 versus $140 \%, p<0.05$ ), it was not changed in normometabolic patients.

Hypermetabolic NSCLC patients undergoing curative resection show an improvement in energy balance caused by both a decreased REE and an increased EI. This positive energy balance results in weight gain, which consists predominantly of FM.
\end{abstract}




\section{Introduction}

Weight loss frequently occurs in patients with lung cancer (1). Both increased energy expenditure (EE) and decreased dietary intake have been incriminated as causative factors for the observed weight loss. Several authors have found an elevated resting energy expenditure (REE) in lung cancer patients (2-4), while others have found no change (5-7). Recently, it has been shown that both an increased REE and a decreased energy intake (EI) relative to EE contribute to weight loss in lung cancer patients. The central localization of the tumor and enhanced systemic concenirations of inflammatory mediators were found to be contributing factors to the elevated REE (8).

To assess the effect of the tumor-bearing state on energy balance it is important to compare the results of cancer patients with control data. Several studies have been published in which small cell lung cancer (SCLC) patients functioned as their own controls by measurement of REE and/or El before and after chemotherapy $(2,4,9)$. In a pilot study with 14 non small cell lung cancer (NSCLC) patients we measured REE before and after surgical resection of the tumor. NSCLC patients with no evidence of tumor recurrence had a significant decrease in REE to a normal level (10). This finding, however, needs to be confirmed in a larger group of patients.

The aim of the current study was to investigate the influence of surgicall removal of the tumor on body weight, body composition, and energy balance in NSCLC patients.

\section{Materials and methods}

\section{Patients}

Fifty-three newly detected primary NSCLC patients were consecutively included in the study. All patients had histologically documented tumors. They all underwent surgical resection of the tumor. The exclusion criteria for the study were: previous treatment with chemotherapy or radiotherapy, treatment with high doses of steroids, severe endocrine abnormalities (insulin-dependent diabetes meliitus, hyper/hypothyroidism), and body temperature exceeding 37.7 o C. Baseline measurements of energy balance (REE, EI, body weight and body composition) prior to the start of treatment (=operation) were made in all fifty-three patients. Repeated measurements were made 3, 6 and 12 months after tumor resection in 39 patients. Fourteen patients were excluded from the repeated measurements, because they died $(n=6)$, they were in a bad physical condition $(n=6)$ or they refused $(n=2)$. The remaining 39 patients were categorized into 30 patients in which tumor recurrence was not likely within 12 months, and nine patients with signs of tumor recurrence during this follow-up period of one year. Presence of recurrence was established by examination of medical records (including chest $\mathrm{X}$-rays) produced during routine follow-up on an outpatient basis.

Tumor stage was assessed according to the tumor-nodes-metastasis (TNM) 
classification for NSCLC based on pre- and postoperative data (11). The study was approved by the medical ethical committee of the university hospital of Maastricht. Informed consent was obtained from all patients.

\section{Resting Energy Expenditure}

REE was measured by indirect calorimetry using a ventilated hood system (Oxycon b; Mijnhardt, Bunnik, the Netherlands). Flow through the canopy was kept constant during measurements and was adjusted to the body weight of the patient, ranging from 35 to 45 liters $/ \mathrm{min}$. The equipment was calibrated at the start of every experiment. The precision of the device was checked monthly by burning methanol with a theoretical respiratory quotient of 0.667 after complete combustion. REE was calculated using the abbreviated Weir formula (12). Before surgery, patients stayed in the hospital and REE was measured between 7 a.m. and 9 a.m after an overnight fast. After surgery, REE was measured on an outpatient basis. Patients visited the hospital at 9 a.m. They had fasted for at least $10 \mathrm{~h}$ and had travelled by car or bus. In an earlier study we showed that variations due to limited physical activities, including a short travel from home to the hospital, do not significantly influence the measurement of REE (13). On both occasions REE was measured on the metabolic ward while at complete rest over a 20$\min$ period.

\section{Body Composition}

Body height was measured with the subject standing barefoot and determined to the nearest $0.5 \mathrm{~cm}$. Body weight was measured with a beam scale (SECA, Germany), with the subject standing without shoes, to the nearest $0.1 \mathrm{~kg}$. Triceps skinfold thickness was measured in triplicate to the nearest $0.2 \mathrm{~mm}$ with a Harpenden skinfold caliper according to Durnin and Womersley (14). Fat free mass (FFM) was assessed using the single frequency bioelectrical impedance analysis (BIA-101; RUL-Systems, Detroit, MI). Resistance was measured with the subject in the supine position on the right side, as described by Lukaski et al (15). The BIA-method is a noninvasive, safe, rapid, and reproducible technique. FFM was measured in the early morning after REE measurement to avoid influence of exercise or eating. In an earlier study we established a good correlation between height ${ }^{2} /$ resistance and total body water (TBW), as assessed by deuterium dilution in elderly cancer patients (16). Based on this study the following patient specific regression equation was used:

TBW $=8.9+0.5\left(\right.$ height $^{2} /$ resistance $) ; \mathrm{FFM}=$ TBW $/ 0.73$.

Fat mass (FM) was calculated as body weight minus FFM. 


\section{Chapter 8}

\section{Dietary Intake}

Dietary intake of the period before admission was estimated using the diet history method with cross-check (17). All interviews were performed by two trained dietitians within the first week after admission to the hospital. Dietary intake was estimated once again using the diet history method by the same dietitian at 3,6 and 12 months after surgery. EI was calculated using the computer with the nutrient data base derived from the Dutch food composition tables (NEVO) (18).

\section{Lung Function Parameter}

Forced expiratory volume in $1 \mathrm{~s}\left(\mathrm{FEV}_{1}\right)$ was measured with a wet spirometer (Pulmonet III; Gould Godart, Bilthoven, the Netherlands); the highest value of at least three technically acceptable spirometric manoeuvres being used. FEV, was expressed as a percentage of the reference value (19).

\section{Statistics}

Weight loss was calculated as the difference between reported pre-illness stable weight minus actual weight. REE was expressed in absolute terms (REE), and per kg FFM (REE/FFM). Measured REE was also compared to predicted REE using the Harris Benedict (HB) equations (20). Subjects with a measured REE above $110 \%$ of that predicted by the $\mathrm{HB}$ formula were arbitrarily considered hypermetabolic.

Statistical analyses were performed using one way analysis of variance followed by the Tukey pairwise multiple comparison procedure. Student's paired t-test was used when appropriate. The Mann-Whitney U test and the Wilcoxon matched-pairs signed-ranks test were used for the statistical analysis of nonparametric data. Frequency data were compared using the $\mathrm{c} 2$ test. Results are presented as mean $\pm \mathrm{SD}$. P-values $<0.05$ was defined as statistically significant. The statistical calculations were performed by the StatView SE + package for the Macintosh. (21).

\section{Results}

The pre-treatment characteristics of patients with curative resection $(n=30)$, and those with tumor recurrence or a new primary tumor $(n=9)$ are summarized in Table 1 . Fourteen patients had no follow-up. These patients with no follow-up were older (70 versus 63 years, $\mathrm{p}<0.05)$ and had a more advanced tumor stage $(6$ stage IIIA tumors versus $2, p<0.05$ ) than patients with repeated measurements and curative tumor resection. REE was not significantly different between the groups. Mean REE/HB of the whole group of 53 patients was $1.14 \%$. Sixty-eight percent (36 out of 53) of the patients were hypermetabolic. 
Table 1: Patient characteristics at diagnosis.

\section{Follow-up}

\begin{tabular}{lll} 
& $\begin{array}{l}\text { No tumor recurrence } \\
(\mathrm{n}=30)\end{array}$ & $\begin{array}{l}\text { tumor recurrence } \\
(\mathrm{n}=9)\end{array}$ \\
\hline Male/female & $20 / 10$ & $8 / 1$ \\
Age (y) & $63 \pm 10$ & $7 / 0 / 2$ \\
Tumor stage (I/II/IIIA) & $25 / 2 / 3$ & $74 \pm 22$ \\
FEV, (\%pred) & $80 \pm 21$ & $75.8 \pm 13.5$ \\
body weight (kg) & $73.4 \pm 14.7$ & $2.3 \pm 3.0$ \\
weight loss (kg) & $1.6 \pm 4.9$ & $52.9 \pm 7.0$ \\
FFM (kg) & $51.2 \pm 7.8$ & $11.0 \pm 2.9$ \\
Triceps (mm) & $12.9 \pm 6.0$ & $1731 \pm 372$ \\
REE (kcal/day) & $1671 \pm 277$ & $32.4 \pm 3.6$ \\
\hline REE (kcal/kg FFM) & $32.6 \pm 3.1$ & \\
\hline
\end{tabular}

Data are expressed as mean $\pm s d$.

In Table 2 changes in body weight, body composition and REE in patients with curative tumor resection are compared with the results in patients with tumor recurrence. These changes are measured over a period of one year except for the patient group with signs of tumor recurrence. In this group of nine, three patients dropped out at 6 months, and only three patients were measured at 12 months. So, the changes in body weight, body composition and REE in patients with tumor recurrence are measured over a period of one year $(n=3)$ or less $(n=6)$. Patients with no signs of tumor recurrence showed an increase in body weight, in contrast to patients with tumor recurrence $(+3.5$ versus $3.6 \mathrm{~kg}, \mathrm{p}<0.005$ ). This weight gain consisted predominantly of FM, while the weight loss consisted for more than half of FFM. Both groups of patients showed a decrease in REE, which was not significantly different between the two groups.

Patients with no signs of tumor recurrence $(\mathrm{n}=30)$ had a significant increase in body weight one year after tumor resection $(73.5$ versus $77.0 \mathrm{~kg}, \mathrm{P}<0.01)$. FFM showed 
Table 2: Changes in body weight, body composition and metabolic rate in patients with and without signs of tumor recurrence

\begin{tabular}{llll}
\hline & $\begin{array}{c}\text { Curative tumor resection } \\
(\mathrm{n}=30)\end{array}$ & $\begin{array}{c}\text { Tumor recurrence } \\
(\mathrm{n}=9)\end{array}$ & p-value \\
\hline$\Delta$ body weight $(\mathrm{kg})$ & $+3.5 \pm 5.6$ & $-3.6 \pm 7.5$ & $<0.005$ \\
$\Lambda \mathrm{FFM}(\mathrm{kg})$ & $+0.5 \pm 3.0^{\prime}$ & $-2.2 \pm 3.4$ & n.s. \\
$\Delta \mathrm{FM}(\mathrm{kg})$ & $+3.4 \pm 6.1^{\prime \prime}$ & $-1.4 \pm 6.2$ & $<0.05$ \\
$\Delta \mathrm{REE}(\mathrm{kcal} / \mathrm{day})$ & $-7.1 \pm 174$ & $-132 \pm 178$ & n.s. \\
$\Delta \mathrm{REE}(\mathrm{kcal} / \mathrm{kg} \mathrm{FFM})$ & $-1.1 \pm 3.3^{\prime}$ & $-1.1 \pm 1.6$ & n.s. \\
\hline
\end{tabular}

Data are expressed as mean $\pm s d$. ' $n=28, n . s .=$ not significant

no significant changes during this year. FM, however, did change, as has been shown by an increase in triceps skinfold $(12.9$ versus $15.2 \mathrm{~mm}, \mathrm{p}<0.01)$. These patients showed a significant reduction in REE after 6 (1676 versus $1607 \mathrm{kcal} / \mathrm{day}, \mathrm{p}<0.05$ ) and 12 months ( 1676 versus $1608 \mathrm{kcal} /$ day, $p<0.05$ ). El/REE was higher after tumor resection than before. However, this difference was not significant.

Body weight, body composition, and REE in hypermetabolic patients with curative tumor resection $(n=20)$ are presented in Table 3 . One year after tumor resection mean body weight has increased by $3.8 \mathrm{~kg}$ (from $74.7 \mathrm{~kg}(\mathrm{t}=0)$ to $78.5 \mathrm{~kg}(\mathrm{t}=3)$ ). FFM showed no significant changes during this year. FM, however, did change, as has been shown by an increase in triceps skinfold $(12.6$ versus $15.5 \mathrm{~mm}, \mathrm{p}<0.05)$ as well. The hypermetabolic patients showed a significant reduction in REE after 3 (1650 versus $1764 \mathrm{kcal} /$ day, $\mathrm{p}<0.01), 6$ (1660 versus $1764 \mathrm{kcal} /$ day, $\mathrm{p}<0.05$ ) and 12 months (1653 versus $1764 \mathrm{kcal} /$ day, $\mathrm{p}<0.05$ ). REE adjusted for $\mathrm{FFM}$ was also lower after tumor resection than before. However, this difference was not always significant.

Body weight, body composition, and REE in normometabolic patients with curative tumor resection $(\mathrm{n}=10)$ are presented in Table 4 . One year after tumor resection mean body weight has increased by $2.7 \mathrm{~kg}$ (from $70.7 \mathrm{~kg}(\mathrm{t}=0)$ to $73.4 \mathrm{~kg}(t=3)$ ). FFM showed no significant changes during this year. FM, however, significantly increased after one year $(22.2$ versus $20.0 \mathrm{~kg}, \mathrm{p}<0.05)$. REE did not change significantly after curative resection in normometabolic patients, except for the measurements after 3 months. 
Table 3: Body weight, body composition, and REE before and 3, 6 and 12 months after curative tumor resection in hypermetabolic patients $(n=20)$

Tumor resection:

\begin{tabular}{lllll} 
& $\begin{array}{l}\text { Before } \\
(\mathrm{t}=0)\end{array}$ & $\begin{array}{l}3 \text { mo after } \\
(\mathrm{t}=1)\end{array}$ & $\begin{array}{l}6 \text { mo after } \\
(\mathrm{t}=2)\end{array}$ & $\begin{array}{l}12 \text { mo after } \\
(\mathrm{t}=3)\end{array}$ \\
\hline body weight $(\mathrm{kg})$ & $74.7 \pm 13.1$ & $74.5 \pm 13.5$ & $76.5 \pm 12.6$ & $78.5 \pm 14.2^{*}$ \\
FFM (kg) & $51.5 \pm 5.5^{\prime}$ & $52.1 \pm 5.5$ & $51.4 \pm 5.5$ & $51.5 \pm 6.0^{\prime}$ \\
FM (kg) & $23.9 \pm 9.4^{*}$ & $22.4 \pm 11.3$ & $25.1 \pm 10.7$ & $26.3 \pm 12.4^{* \prime}$ \\
Triceps (mm) & $12.6 \pm 5.7$ & $12.5 \pm 4.1$ & $12.6 \pm 5.1$ & $15.5 \pm 6.7^{*}$ \\
REE (kcal/day) & $1764 \pm 215$ & $1653 \pm 183^{* *}$ & $1660 \pm 153^{* *}$ & $1650 \pm 215^{*}$ \\
REE (kcal/kgFFM) & $34.3 \pm 2.3^{\prime}$ & $31.9 \pm 3.0^{* *}$ & $32.5 \pm 3.9$ & $32.0 \pm 3.3^{\prime}$ \\
\hline
\end{tabular}

Data are expressed as mean $\pm s d,{ }^{\prime} n=19, \quad * p<0.05$ compared to $t=0,{ }^{* *} p<0.01$ compared to $t=0$

Table 4: Body weight, body composition, and REE before and 3, 6 and 12 months after curative fumor resection in normometabolic patients $(n=10)$

Tumor Resection

\begin{tabular}{lllll} 
& $\begin{array}{l}\text { Before } \\
(\mathrm{t}=0)\end{array}$ & $\begin{array}{l}3 \text { mo after } \\
(\mathrm{t}=1)\end{array}$ & $\begin{array}{l}6 \text { mo after } \\
(\mathrm{t}=2)\end{array}$ & $\begin{array}{l}12 \mathrm{mo} \text { after } \\
(\mathrm{t}=3)\end{array}$ \\
\hline weight $(\mathrm{kg})$ & $70.7 \pm 18.3$ & $71.0 \pm 17.9$ & $73.5 \pm 17.6^{*}$ & $73.4 \pm 17.3^{*}$ \\
FFM $(\mathrm{kg})$ & $50.7 \pm 11.4$ & $51.0 \pm 10.2$ & $49.5 \pm 10.5$ & $51.2 \pm 11.3$ \\
FM $(\mathrm{kg})$ & $20.0 \pm 9.9$ & $20.0 \pm 8.9$ & $24.0 \pm 9.5$ & $22.2 \pm 8.6^{*}$ \\
Triceps $(\mathrm{mm})$ & $14.0 \pm 6.7$ & $12.6 \pm 6.5$ & $10.9 \pm 3.0$ & $15.8 \pm 6.3$ \\
REE $(\mathrm{kcal} / \mathrm{day})$ & $1484 \pm 303$ & $1564 \pm 273^{* *}$ & $1502 \pm 302$. & $1502 \pm 300$ \\
REE $(\mathrm{kcal} / \mathrm{kgFFM})$ & $29.5 \pm 1.7$ & $30.9 \pm 2.6$ & $30.5 \pm 3.7$ & $29.6 \pm 2.7$ \\
\hline
\end{tabular}

Data are expressed as mean $\pm s d$. $p$-values: $* p<0.05$ compared $t o t=0, * *<<0.01$ compared to $t=0$. 


\section{Chapter 8}

Data on all components of energy balance before and 3,6 and 12 months after curative tumor resection in hypermetabolic as well as in normometabolic patients are shown in Table 5. Body weight has increased in both groups of patients one year after successful removal of the tumor $(+3.8$ and $+2.7 \mathrm{~kg}$, respectively). However, while EI/REE was significantly increased in hypermetabolic patients (106 versus $140 \%, \mathrm{p}<0.05$ ), it was not changed in normometabolic patients.

Table 5: Energy balance before and 3, 6 and I2 months after curative tumor resection in hypermetabolic and normometabolic patients

Tumor resection

$\begin{array}{llll}\text { Before } & 3 \text { mo after } & 6 \text { mo after } & 12 \text { mo after } \\ (t=0) & (\mathrm{t}=1) & (\mathrm{t}=2) & (\mathrm{t}=3)\end{array}$

Hypermetabolic patients $(\mathrm{n}=20 ; \mathrm{REE} / \mathrm{HB}=121 \pm 9 \%)$

\begin{tabular}{lcccc}
\hline body weight (kg) & $74.7 \pm 13.1$ & $74.5 \pm 13.5$ & $76.5 \pm 12.6$ & $78.5 \pm 14.2^{*}$ \\
REE $(\mathrm{kcal} /$ day) & $1764 \pm 215$ & $1653 \pm 183^{* *}$ & $1660 \pm 153^{*}$ & $1650 \pm 215^{*}$ \\
EI $(\mathrm{kcal} /$ day) & $1796 \pm 362$ & $2122 \pm 646$ & $2079 \pm 806$ & $2235 \pm 755$ \\
EI $/$ REE $(\%)^{\prime}$ & $106 \pm 27$ & $130 \pm 41$ & $128 \pm 53$ & $140 \pm 51^{*}$ \\
\hline
\end{tabular}

Normometabolic patients $(n=10 ;$ REE/HB $=102 \pm 6 \%)$

\begin{tabular}{lcccc}
\hline body weight $(\mathrm{kg})$ & $70.7 \pm 18.3$ & $71.0 \pm 17.9$ & $73.5 \pm 17.6^{* * *}$ & $73.4 \pm 17.3^{* *}$ \\
REE (kcal/day) & $1484 \pm 303$ & $1564 \pm 273^{* * *}$ & $1502 \pm 302$ & $1502 \pm 300$ \\
E! $(\mathrm{kcal} / \text { day })^{\prime \prime}$ & $1727 \pm 379$ & $1783 \pm 485$ & $1884 \pm 537$ & $1833 \pm 512$ \\
EI $/$ REE $(\%)^{\prime \prime}$ & $110 \pm 27$ & $110 \pm 32$ & $120 \pm 35$ & $117 \pm 37$ \\
\hline
\end{tabular}

Data are expressed as mean $\pm s d$. " $n=9, " n=6, p$-values:" $p<0.05$ compared to $t=0, * * p<0.01$. compared to $t=0$ 


\section{Discussion}

It has been suggested that an increased EE and a decreased EI contribute to the weight loss commonly seen in lung cancer patients (8). To assess the effects of the tumorbearing state on energy balance it is important to compare the results of cancer patients with control data. Therefore, in the current study NSCLC patients functioned as their own controls by measurement of body weight, body composition, REE and EI before and after surgical resection of the tumor.

The present study shows that hypermetabolic NSCLC patients have an elevated REE which returns to a normal level within three months after curative surgery. A decrease in REE of the order found in this study ( $>100 \mathrm{kcal} /$ day) is definitely of significance, because it can account for a weight gain of about $1 \mathrm{~kg}$ in 3 months. REE in normometabolic patients did not change after curative surgery. In addition, REE in patients with tumor recurrence was also unchanged. These results are in agreement with the results of our previous study in 14 NSCLC patients (10).

Measurements of REE in cancer patients before and after (un)successful treatment have been described in earlier studies. In some of these studies only a few patients were measured, and none of them had lung cancer (22-24). In others, SCLC patients were measured before and after chemotherapy $(2,4,9)$. Luketich et al. prospectively studied a heterogenous group of 68 cancer patients (of whom six had lung cancer) by measuring REE before and five days after tumor resection (25). In all but one of these studies a reduction in REE was found in patients with successful treatment. In contrast, patients who did not respond to chemotherapy or patients who had palliative resection showed no significant change in REE or even an increase. Furthermore, the present study shows that EI relative to REE was significantly increased in hypermetabolic patients after 12 months, while it was not changed in normometabolic patients. This increase in EI/REE is caused by both a reduction in REE and an increment in EI. These results are in agreement with the study of McR Russell et al. in which hypermetabolic SCLC patients with complete response to therapy had a reduced REE and an increased EI (2). The changes in REE and EI in hypermetabolic patients with successful removal of the tumor resulted in a positive energy balance. Indeed, body weight increased by $3.8 \mathrm{~kg}$. This weight gain completely consisted of FM. In contrast, the normometabolic patients who were treated successfully showed no change in energy balance. Surprisingly, however, this group had an increase in body weight of $2.7 \mathrm{~kg}$, also consisting predominantly of FM.

An explanation for this controversy may be related to the methods for measuring the two components of the energy balance. The measurement of REE with the ventilated hood systemhas proven to be accurate and precise (26). So, the observation that REE changes did occur in hypermetabolic patients is important. However, there is some discussion on the reliability of the results of self-reported food intake as a measure for EI (26). EI in the normometabolic patients exceeded REE by only 10-20\%. According 


\section{Chapter 8}

to the criteria of the World Health Organization (WHO) energy requirement of a healthy, retired elderly man equals 1.51 times REE (27). Since the introduction of the doubly-labelled water method, which allows validation of data on EI in subjects who are in energy balance, it is generally believed that self-reported dietary intake underestimates the energy needs, even when a reliable method is used (26). One can only speculate on the reasons for underreporting in normometabolic patients. Furthermore, it has to be emphasized that EI was measured in only 6 normometabolic patients.

Normally, when EI exceeds EE, $\pm 75 \%$ of excess energy is stored as FM $(28,29)$. This finding is in agreement with the results of this study in successfully treated NSCLC patients in which weight gain also predominantly consists of FM. Patients with tumor recurrence were apparently in a negative energy balance, since body weight decreased by $3.6 \mathrm{~kg}$. This weight loss consisted for more than half of FFM.

When EI is lower than EE, energy deficit is covered from both FFM and FM. This energy-partitioning between FFM and FM during weight loss depends on body composition of the subject, the relative size of the energy deficit, and the effects of disease. Severe energy deficits in lean subjects, with catabolic illnesses will produce proportionally the greatest loss in FFM (28-30). In this study patients with tumor recurrence showed a mean body fat \% of $30.0 \%$ and a mean EI relative to REE of $130 \%(\mathrm{n}=5$; data not shown), which suggests that the substantial loss of FFM is determined by the tumor-bearing state. It has to be emphasized that the number of measurements in patients with tumor recurrence was small $(n=9, n=6$ and $n=3$ at 3 , 6 and 12 months, respectively). Therefore, before definite conclusions can be made, more longitudinal data are needed in this group of patients.

It is suggested in literature that cigarette smoking influences energy metabolism. Conflicting results on smoking behaviour and increased EE have been reported. Hofstetter et al. reported a significant elevation of 24-h EE to be associated with smoking (31). Some studies reported a decrease of REE after smoking cessation (32, $33)$, while others found no effect $(34,35)$. In earlier studies we found that the increase in REE in lung cancer patients cannot be explained by smoking behaviour $(8,10)$. In the present study seventeen (out of 30 ) patients with curative tumor resection were smokers before diagnosis of their disease. Thirteen of them stopped smoking after tumor resection. When this group of 30 patients with curative tumor resection was subdivided according to smoking behaviour: stopped smoking versus no change in smoking behaviour, the decrease in REE/FFM after surgical removal of the tumor was not significantly different between the two groups (data not shown). Therefore, we conclude that the fall in REE in lung cancer patients is rather the result of successful removal of the tumor than of cessation of smoking.

In conclusion, the results of the present study suggest that NSCLC patients undergoing curative resection show an improvement in energy balance caused by both a decreased $\mathrm{REE}$ and an increased EI. This positive energy balance results in weight gain, which consists predominantly of FM. 


\section{References}

1. Kern KA, Norton JA. Cancer cachexia. JPEN 1988; 12:286-295

2. Russell D McR., Shike M, Marliss EB, Detsky AS, Shepherd FA, Feld R, Evans WK, Jeejeebhoy $\mathrm{KN}$. Effects of total parenteral nutrition and chemotherapy on the metabolic derangements in small cell lung cancer. Cancer Res 1984; 44:1706-1711

3. Fredrix EWHM, Wouters EFM, Soeters PB, Aalst ACJM van der, Kester ADM, Meyenfeldt MF von, Saris WHM. Resting energy expenditure in patients with non-small cell lung cancer. Cancer 1991; 68: 16161-1621

4. Jebb SA, Osborne RJ, Dixon AK, Bleehen NM, Elia M. Measurements of resting energy expenditure and body composition before and after treatment of small cell lung cancer. Ann Oncology 1994; 5:915-919

5. Hansell DT, Davies JWL, Burns HJG. The effects on resting energy expenditure of different fumor types. Cancer 1986; 58:1739-1744

6. Nixon DW, Kutner M, Heymsfield S, Foltz AT, Carty Ch, Seitz S, Casper K, Evans WK, Jeejeebhoy KN, Daly JM, Heber D, Poppendiek H, Hoffman FA. Resting energy expenditure in lung and colon cancer. Metabolism 1988; 37:1059-1064

7. Melville S, Mc Nurlan MA, Calder AG, Garlick PJ Increased protein turnover despite normal energy metabolism and responses to feeding in patients with lung cancer. Cancer Res 1990; 50: 1125-1131

8. Staal-van den Brekel AJ, Schols AMWJ, ten Velde GPM, Buurman WA, Wouters EFM. Analysis of the energy balance in lung cancer patients. Cancer Res 1994; 54:6430-6433

9. Simonsen L, Bülow J, Sengelov H, Madsen J, Ovesen L. Glucose-induced thermogenesis in patients with small call lung carcinoma. Before and after inhibition of tumor growth by chemotherapy. Clin Physiology 1993; 13:385-396

10. Fredrix EWHM, Soeters PB, Wouters EFM, Deerenberg IM, Meyenfeldt MF von, Saris WHM. Effect of different tumor types on resting energy expenditure. Cancer Res 1991; 51:6138-6141

11. Mountain CF. A new international staging system for lung cancer. Chest 1986: 89:225s-233s

12. Weir JB New methods for calculating metabolic rate with special reference to protein metabolism. J Physiol 1949; 109:1-12

13. Fredrix EWHM, Soeters PB, Meyenfeldt MF von, Saris WHM. Measurement of resting energy expenditure in a clinical setting. Clin Nutr 1990; 9:299-304

14. Durnin J, Womersley K. Body fat assessed from total body density and its estimation from skinfold thickness: measurements on 481 men and women aged 16 to 72 years. Br J Nutr 1974; 32:77-97

15. Lukaski HC, Johnson PE, Bolonchuk WW, Lykken GI. Assessment of fat-free mass using bioelectrical impedance measurements of the human body. Am I Clin Nutr 1985; 41:810-817

16. Fredrix. EWHM, Saris WHM, Soeters PB, Kester ADM, Meyenfeldt M.F. von, Wouters EFM, Westerterp KR Estimation of body composition by bioelectrical impedance in cancer patients. Eur J Clin Nutr 1990; 44:749-752

17. Black G. A review of validations of dietary assessment methods. Am J Epidemiol 1982; 115:492505

18. NEVO Tabel. Stichting Nederlands Voedingsstoffenbestand. 's-Gravenhage, the Netherlands: Voorlichtingsbureau voor de Voeding. 1990.

19. Quanjer PH. Standardized lung function testing. Bull Eur Physiopathol Respir 1983; 19:7-44

20. Harris JA,Benedict FG. A biometric study of basal metabolism in man. Publication 279. Washington, DC: Carnegie Institute of Washington, 1919.

21. StatView SE + package for the Macintosh. Berkeley: Abacus Concepts, Inc., 1987

22. Arbeit JM, Lees DE, Brennan MF. Resting energy expenditure in controls and cancer patients with localized and diffuse disease. Ann Surg 1984; 199:292-298 


\section{Chapter 8}

23. Bozzetti F, Pagnoni AM, Del Vecchio M. Excessive caloric expenditure as a cause of malnutrition in patients with cancer. Surg Gynecol Obstet 1980; 150:229-234

24. Warnold I, Lundholm K, Schersten T. Energy balance and body composition in cancer patients. Cancer Res 1978; 38:1801-1807

25. Luketich JD, Mullen J, Feurer ID, Sternlieb J, Fried RC. Ablation of abnormal energy expenditure by curative tumor resection. Arch Surg 1990; 125:337-341

26. Westerterp KR. Energy expenditure. In: Westerterp-Plantenga MS, Fredrix EMWHM, Steffens AB. Food intake and energy expenditure. Boca Raton, Florida: CRC Press, 1995:235-257

27. World health Organization. Energy and protein requirements, report of a joint FAO/WHO/UNU expert consultation (Technical report series 724). Geneva: WHO, 1985.

28. Forbes GB. Lean body mass-body fat interrelationships in humans. Nutr Rev 1987; 45:225-231

29. Prentice AM, Goldberg GR, Jebb SA, Black AE, Murgatroyd PR, Diaz EO. Physiological responses to slimming. Proc Nutr Soc 1991; 50:441-458

30. Brennan MF. Uncomplicated starvation versus cancer cachexia. Cancer Res 1977; 37:2359-2364

31. Hofstetter A, Schutz Y, Jéquier E, Wahren J. Increased 24-hour energy expenditure in cigarette smokers. N Engl J Med 1986; 314:79-82.

32. Moffat RJ, Owens SG. Cessation from smoking: changes in body weight, body composition, resting metabolism and energy consumption. Metabolism 1991; 40:465-470

33. Dallosso HM, James WPT. The role of smoking in the regulation of energy balance. Int J Obesity $1984 ; 8: 365-375$

34. Stamford BA, Matter S, Fell RD, Papanek P. Effects of smoking cessation on weight gain, metabolic rate, caloric consumption, and blood lipids. Am J Clin Nutr 1986; 43:486-494

35. Burse RL, Bynum GD, Pandolf KB, Goldman RF, Sims EAH, Danforth ER. Increased appetite and unchanged metabolism upon cessation of smoking with diet held constant. Physiologist 1985; 18:157 


\title{
THE EFFECTS OF TREATMENT WITH CHEMOTHERAPY ON ENERGY METABOLISM AND INFLAMMATORY MEDIATORS IN SMALL CELL LUNG CARCINOMA
}

\begin{abstract}
A disturbed energy balance has been demonstrated in lung cancer patients. Both an enhanced resting energy expenditure (REE) and a decreased energy intake contribute to weight loss. Enhanced systemic levels of inflammatory mediators were found to be related to the enhanced REE in lung cancer. The aim of the present study was to investigate energy metabolism and systemic levels of inflammatory mediators in small cell lung carcinoma (SCLC) patients before and after treatment with chemotherapy.

To this end twelve newly diagnosed SCLC patients were consecutively included in the study. REE was measured by indirect calorimetry and body composition was determined by bioelectrical impedance (BIA) before and I month after treatment. To assess the inflammatory state the acute phase proteins, C-reactive protein (CRP) and lipopolysaccharide binding protein (LBP), both soluble TNF-receptors, (sTNF-R)-55 and sTNF-R75, and soluble intercellular adhesion molecule (sICAM)-1 were measured in plasma before and I month after treatment. CRP was assessed by turbidemetry, while the other inflammatory parameters were measured by ELISA. A significant reduction in REE was found irrespective of therapeutic outcome while body weight and body composition remained stable. The acute phase proteins CRP and LBP reduced significantly after treatment with chemotherapy, while both sTNFreceptors and sICAM-1 remained enhanced. No correlation, however, existed between the decrease in REE and the decrease of the acute phase proteins. In conclusion, chemotherapeutic treatment attenuates the tumor related metabolic derangements and acute phase response.
\end{abstract}




\section{Chapter 9}

\section{Introduction}

Weight loss is a frequently occurring problem in lung cancer patients. Severe weight loss ( $210 \%$ weight loss) has been found in $30 \%$ of the patients with newly detected lung cancer (1). Both an increased resting energy expenditure (REE) and a decreased energy intake contribute to weight loss in lung cancer patients (1-4). Besides body composition, the localization of the tumor in the central airways and enhanced systemic levels of inflammatory mediators were found to be determining factors of an increased REE in lung cancer patients $(1,5)$. The involvement of inflammatory mediators in metabolic derangements has been demonstrated in experimental animal studies as weli as in oncological patients with different tumor types (5-8).

Next to general tumor characteristics, histology has to be considered as a factor related to energy metabolism in lung cancer patients. Lung cancer can be divided into small cell lung carcinoma (SCLC) and NSCLC (9). About $20 \%$ of the patients with lung cancer have SCLC. SCLC has different characteristics compared to NSCLC of which the presence of neurosecretory granules, a more aggressive behavior and a good response to chemotherapy are the most important (10).

An enhanced REE adjusted for FFM was demonstrated in SCLC patients compared to NSCLC patients in a former study of our group (11). Limited data are published about the effects of treatment on REE in SCLC $(4,12)$. No follow-up data are available at present about the effects of treatment on REE in relation to levels of inflammatory mediators in SCLC. The aim of the present study was to assess energy metabolism and systemic levels of inflammatory mediators in patients with SCLC before and after standard treatment with chemotherapy. The acute phase response was assessed by $\mathrm{C}$-reactive protein (CRP) and lipopolysaccharide binding protein (LBP), while inflammation was evaluated by measurement of both soluble TNFreceptors, sTNF-Receptor (sTNF-R)-55 and sTNF-R75, and soluble intercellular adhesion molecule (siCAM) 1 , a member of the immunoglobulin supergene family.

\section{Subjects and methods}

\section{Patients}

Twelve newly diagnosed SCLC patients were consecutively included into the study. All patients had histologically documented tumors and had not yet received ireatment before the first measurements. The exclusion criteria for the study were: previous treatment with chemotherapy or radiotherapy, treatment with high doses of corticosteroids, severe endocrine abnormalities (insulin dependent diabetes mellitus, hyper/hypothyroidism) and body temperature exceeding $37.7{ }^{\circ} \mathrm{C}$. The two-stage classification system was used for SCLC $(13,14)$. Staging procedures consisted of 
physical and neurological examination, bronchoscopy to collect materials for histologic examination, echoscopy of abdomen, CT-scan of the thorax and abdomen, CT-scan and MRI of the brain and a bonescan. Patients were treated with 5 courses of chemotherapy consisting of Cyclophosphamide $1000 \mathrm{mg} / \mathrm{m}^{2}$ on day 1 , Adriamycine $45 \mathrm{mg} / \mathrm{m}^{2}$ on day 1 and Etoposide $100 \mathrm{mg}$ on day 1,3 and 5 with dose reduction of $25 \%$ if necessary. Approximately one month after the end of treatment, patients were restaged. Tumor responses were defined according to accepted criteria $(13,14)$. The study was approved by the medical ethical committee of the university hospital of Maastricht. Written informed consent was obtained from all patients.

\section{Resting Energy Expenditure}

REE was measured by indirect calorimetry using a ventilated hood system (Oxycon $B^{*}$, Mijnhardt, Bunnik, The Netherlands). Flow through the canopy was kept constant during measurements and was adjusted to the weight of the patient, ranging from 35 to $45 \mathrm{~L} / \mathrm{min}$. The equipment was calibrated at the start of every experiment. The accuracy of the procedure was checked monthly by burning methanol (RQ of 0.667 after complete combustion). After an overnight fast in the hospital and while at complete rest, the pre-treatment REE measurement was made on the metabolic ward over a 20 minute period between $7 \mathrm{a} . \mathrm{m}$. and $9 \mathrm{a} . \mathrm{m}$. under quiet circumstances. The post-treatment measurement was performed similarly but on an outpatient basis. Fredrix et al. (15) showed that variations due to limited physical activities, inciuding a short travel from home to the hospital, did not significantly influence the measurement of REE.

\section{Body composition}

Body height was measured with the subject standing barefoot and determined to the nearest $0.5 \mathrm{~cm}$. Body weight was measured with a beam scale (SECA, Germany), with the subject standing without shoes in underwear, to the nearest $0.1 \mathrm{~kg}$. Fat free mass (FFM) was assessed using the single frequency bioelectrical impedance (BI) analysis (RJL-Systems, BIA-101, Detroit, M.I.). Resistance was measured with the subject in supine position on the right side, as described by Lukaski (16). FFM was measured in the early morning after REE-measurement to avoid influence of exercise or eating $(17,18)$. The BI-method is a non-invasive, safe, rapid and reproducible measurement of body composition $(19,20)$. In an earlier study, a good correlation was established between height ${ }^{2} /$ resistance and total body water (TBW), as assessed by deuterium dilution in elderly cancer patients. The patient specific regression equation used was based on that study (21). Adjustment of REE for the metabolically active tissue mass or FFM is indicated for a correct interpretation of the variations in REE (16-18). Fat mass (FM) was calculated as body weight minus FFM. 


\section{Chapter 9}

\section{Dietary Intake}

Dietary intake during the period prior to admission and after treatment was estimated using the diet history method (22). All interviews were performed by the same trained dietician within the first week after admission to the hospital and after the chemotherapeutic regimens. Dietary intake was calculated based on the nutrient data base derived from the Dutch food composition tables (NEVO) (23).

\section{Plasma samples}

Blood was obtained by venepuncture from patients before breakfast at the same day of the REE measurement. Blood was collected in evacuated blood collection tubes (Sherwood Medical, St. Louis, MO) containing $50 \mathrm{IU}$ Heparin (Leo Pharmaceutical Products B.V., Weesp, The Netherlands). Plasma was separated from blood cells by centrifugation at $1000 \mathrm{G}$ for 5 minutes within 1 hour after collection. Plasma samples were stored at $-70^{\circ} \mathrm{C}$ until analysis.

\section{Measurement of inflammatory mediators}

In order to assess inflammation, a series of inflammatory mediators were determined in plasma. Both soluble TNF-receptors, sICAM-1 and the acute phase proteins CRP and LBP were measured using sandwich ELISA as described elsewhere (24-26). CRP was determined as described below. In short, for measurement of sTNF-R55 and sTNF-R75, MAbs MR1-1 and MR2-2 were used respectively for coating. Specific biotin labelled polyclonal rabbit anti-sTNF-R IgG were used as detector reagents. The standards used were recombinant human sTNF-R55 and sTNF-R75. The detection limit of both assays was $100 \mathrm{pg} / \mathrm{ml}$. For sICAM-1 ELISA, mAb HM.2 was used for coating and recombinant human ICAM-1 was used as a standard. Biotinylated Mab HM. I was used for detection. The detection limit of the assay was $400 \mathrm{pg} / \mathrm{ml}$. Polyclonal rabbit anti human recombinant LBP IgG was used as coating for the LBP ELISA and biotin labelled polyclonal rabbit anti human recombinant LBP $\operatorname{lgG}$ was used for detection of LBP. The standard used was recombinant LBP. Washing and dilution was performed in buffer containing $40 \mathrm{mM}$ $\mathrm{MgCl}$ for preventing disturbance by LPS of LBP recovery in the ELISA. The detection limit of the assay was $200 \mathrm{pg} / \mathrm{ml}$. Immuno assay plates (Nunc-Immuno Plate Maxisorp, Roskilde, Denmark) were used for the ELISA assays. Biotinylated samples were detected with streptavidin-peroxidase conjugate (Dako, Glostrup, Denmark). TMB (3, 3',5, $5^{\prime}$-tetramethylbenzidine, Kirkegaard \& Perry Lab., Gaithersburg, MD) was used as a substrate. Photo-spectometry $(450 \mathrm{~nm})$ was performed using a micro ELISA auto-reader.

CRP was measured by turbidimetry. The detection limit of the assay was $5 \mu \mathrm{g} / \mathrm{ml}$. 


\section{Biochemical parameters}

In order to exclude hyper/hypothyroidism, thyroid stimulating hormone (TSH) was assessed with an immunoradiometric assay. Cortisol was determined in order to evaluate adrenal function and possible ectopic cortisol production as could be observed in SCLC $(27,28)$. Cortisol was measured with a radioimmunoassay. Plasma creatinine was used as a renal function parameter and detected by the modificated Jassé-reaction (Dimension, Dupont, France) (29).

\section{Statistics}

Weight loss was calculated as the difference between reported preillness stable weight minus actual weight. REE was expressed in absolute terms and adjusted for FFM according to Ravussin (30). Statistical analyses were performed using the paired Students $t$ test when appropriate. The Wilcoxon test was used for analysis of non-parametric data. Since impaired renal clearance leads to increased sTNFreceptor concentrations $(31,32)$, the plasma concentrations of sTNF-R55 and sTNFR75 were analyzed together with serum creatinine. Therefore an analysis of covariance was performed, using plasma creatinine as covariable, and considering sTNF-R55 and sTNF-R75 as factors in the statistical model. Frequency data were compared using the chi-square test. Results are presented as mean \pm standard deviation (SD). P-values $<0.05$ were defined as statistically significant. The statistical calculations were performed by the SPSS/PC +4.0 package (33).

\section{Results}

The pre-treatment characteristics of the SCLC patients are summarized in Table 1. Ten men and 2 women were included in the study (age $62 \pm 10$ years). Mean weight loss for the whole group was $4.0 \pm 4.5 \mathrm{~kg}$. Five patients were current smokers, while 7 patients stopped smoking during the last six months. Mean levels of TSH were $1.4 \pm 0.8 \mathrm{mU} / \mathrm{l}$ and mean levels of cortisol were $588 \pm 130 \mathrm{nmol} / \mathrm{l}$. Both TSH and cortisol levels were within the normal range (TSH normal range 0.4$3.5 \mathrm{mU} / 1$, Cortisol normal range $200-700 \mathrm{nmol} / \mathrm{l})$. Normal renal function according to plasma creatinine was found in the SCLC patients before $(83 \pm 22 \mu \mathrm{mol} / \mathrm{l})$ and after treatment $(76 \pm 14 \mu \mathrm{mol} / \mathrm{l})$. All patients showed tumor reduction after treatment and could be classified as partial or complete remission. Four patients showed a complete remission, while 8 patients showed a partial remission of the tumor after treatment with chemotherapy.

Data on body composition and energy balance of the SCLC patients before and after treatment are given in Table 2. Body weight and body composition of the patients remained stable. REE expressed in absolute value $(1628 \pm 219 \mathrm{kcal} /$ day versus 


\section{Chapter 9}

Table I: Description of the study population

Physical characteristics

$\mathrm{M}: \mathrm{F}$

$10: 2$

Age (yr)

$62 \pm 10$

Weight (kg)

$63.7 \pm 9.5$

Height $(\mathrm{cm})$

$168.1 \pm 6.4$

FFM (kg)

$48.2 \pm 5.8$

PIBW (\%)

$97.7 \pm 11.1$

Weight loss (kg)

$4.0 \pm 4.5$

Tumor Stage (n)

Limited disease

4

Extensive disease

8

Data are expressed as mean $\pm s d ; F F M=$ fat free mass $;$ PIBW $=$ Percentage Ideal Body Weight : $n=$ number of patients

Table 2: Comparison of body composition and energy balance before and after treatment in SCLC patients

\begin{tabular}{llll}
\hline & $\begin{array}{l}\text { Visit 1 } \\
(\mathrm{N}=12)\end{array}$ & $\begin{array}{l}\text { Visit 2 } \\
(\mathrm{N}=12)\end{array}$ & p-value \\
\hline Weight $(\mathrm{kg})$ & $63.7 \pm 9.5$ & $65.5 \pm 10.0$ & \\
FFM $(\mathrm{kg})$ & $48.2 \pm 5.8$ & $49.1 \pm 6.0$ & \\
FM (kg) & $15.5 \pm 7.5$ & $16.4 \pm 7.3$ & $*$ \\
REE (kcal/day) & $1628 \pm 219$ & $1475 \pm 130$ & $*$ \\
adjusted REE (kcal/day) & $1807 \pm 226$ & $1629 \pm 160$ & \\
\hline
\end{tabular}

Data are expressed as mean $\pm s d: p$-values: ${ }^{*} p=0.01,{ }^{* *} p<0.005 ; F F M=$ fat free mass $; F M=$ fat mass ; $R E E=$ resting energy expenditure

$1475 \pm 130 \mathrm{kcal} /$ day, $\mathrm{p}=0.01)$ and REE adjusted for FFM $(1807 \pm 226 \mathrm{kcal} /$ day versus $1629 \pm 160 \mathrm{kcal} / \mathrm{day}, \mathrm{p}<0.005$ ) decreased significantly after treatment. Energy intake was measured in a subgroup before and after treatment and did not change significantly $(2156 \pm 444$ versus $2154 \pm 391 \mathrm{kcal} /$ day $)$.

When the patients were divided according to tumor response after treatment, complete remission versus partial remission, no significant differences were found in 
Table 3: Systemic levels of inflammatory mediators in SCLC: before and after treatment with chemotherapy

\begin{tabular}{llll}
\hline & $\begin{array}{l}\text { Visit 1 } \\
(\mathrm{n}=12)\end{array}$ & $\begin{array}{l}\text { Visit 2 } \\
(\mathrm{n}=12)\end{array}$ & p-value \\
\hline sTNF-R55 $(\mathrm{ng} / \mathrm{ml})$ & $1.6 \pm 0.6$ & $1.5 \pm 0.5$ & \\
sTNF-R75 $(\mathrm{ng} / \mathrm{ml})$ & $2.0 \pm 1.0$ & $2.0 \pm 0.8$ & \\
sICAM-1 $(\mathrm{ng} / \mathrm{ml})$ & $78.0 \pm 40.4$ & $76.8 \pm 27.8$ & $*$ \\
CRP $(\mathrm{ug} / \mathrm{ml})$ & $33 \pm 41$ & $15 \pm 20$ & $*$ \\
LBP $(\mathrm{ug} / \mathrm{ml})$ & $23.0 \pm 10.9$ & $16.3 \pm 8.5$ & $*$ \\
\hline
\end{tabular}

Data are expressed as mean $\pm s d ; p$-values: ${ }^{*} p<0.05 ;$ sTNF-R55 = soluble TNF-receptor 55 ; sICAM-I = soluble Intercellular Adhesion Molecule $1 ; C R P=C$-reactive protein $: L B P=L P S$ binding protein

Table 4: Comparison of differences in body composition and energy expenditure between SCLC parients with complete and partial remission after treatment with chemotherapy

\begin{tabular}{lll}
\hline Visit 2 - visit 1 & $\begin{array}{l}\text { Compiete remission } \\
(\mathrm{n}=4)\end{array}$ & $\begin{array}{l}\text { Partial remission } \\
(\mathrm{n}=8)\end{array}$ \\
\hline$\delta$ Weight $(\mathrm{kg})$ & $3.8 \pm 3.4$ & $0.7 \pm 5.7$ \\
$\delta \mathrm{FFM}(\mathrm{kg})$ & $0.0 \pm 1.3$ & $1.3 \pm 3.4$ \\
$\delta \mathrm{FM}(\mathrm{kg})$ & $3.8 \pm 3.8$ & $-0.5 \pm 4.5$ \\
$\delta \mathrm{REE}(\mathrm{kcal} /$ day) & $-124 \pm 37$ & $-168 \pm 214$ \\
$\delta$ adjusted REE (kcal/day) & $-124 \pm 71$ & $-205 \pm 194$ \\
\hline
\end{tabular}

Data are expressed as mean $\pm s d ; F F M=$ fat free mass $; F M=$ fat mass $; R E E=$ resting energy expenditure

the decrease of the metabolic parameters between the two groups. The 6 REE for patients with complete remission $(n=4)$ was $-124 \pm 37 \mathrm{kcal} /$ day versus $-168 \pm 214$ $\mathrm{kcal} /$ day for patients with partial remission $(\mathrm{n}=8)$, while the ô adjusted REE was $124 \pm 71 \mathrm{kcal} /$ day for patients with complete remission versus $-205 \pm 194 \mathrm{kcal} /$ day for patients with partial remission (Table 3).

The systemic levels of inflammatory mediators are summarized in Table 4. Both acute phase proteins CRP $(33 \pm 41 \mu \mathrm{g} / \mathrm{ml}$ versus $15 \pm 20 \mu \mathrm{g} / \mathrm{ml}, \mathrm{p}<0.05)$ and LBP $(23.0 \pm 10.9 \mu \mathrm{g} / \mathrm{ml}$ versus $16.3 \pm 8.5 \mu \mathrm{g} / \mathrm{ml}, \mathrm{p}<0.05)$ decreased significantly after treatment with chemotherapy, while sTNF-R55 $(1.6 \pm 0.6 \mathrm{ng} / \mathrm{ml}$ versus $1.5 \pm 0.5$ $\mathrm{ng} / \mathrm{ml})$, sTNF-R75 $(2.0 \pm 1.0 \mathrm{ng} / \mathrm{ml}$ versus $2.0 \pm 0.8 \mathrm{ng} / \mathrm{ml})$ and sICAM-I 


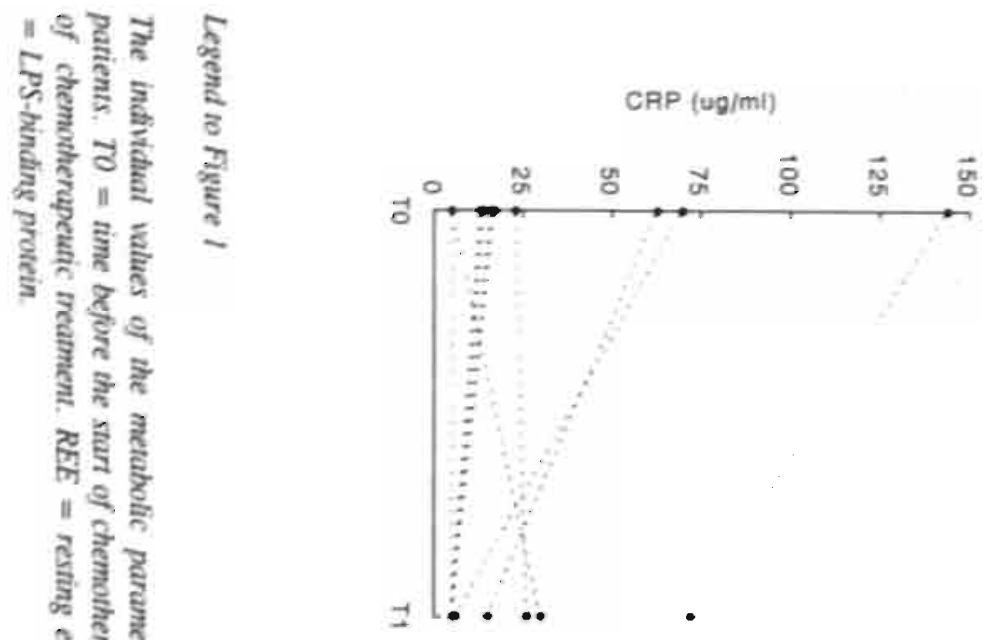

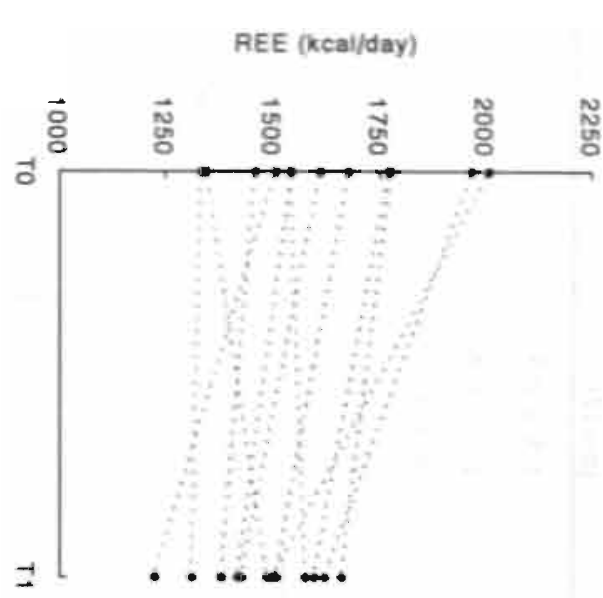

Adjusted REE (kcal/day)
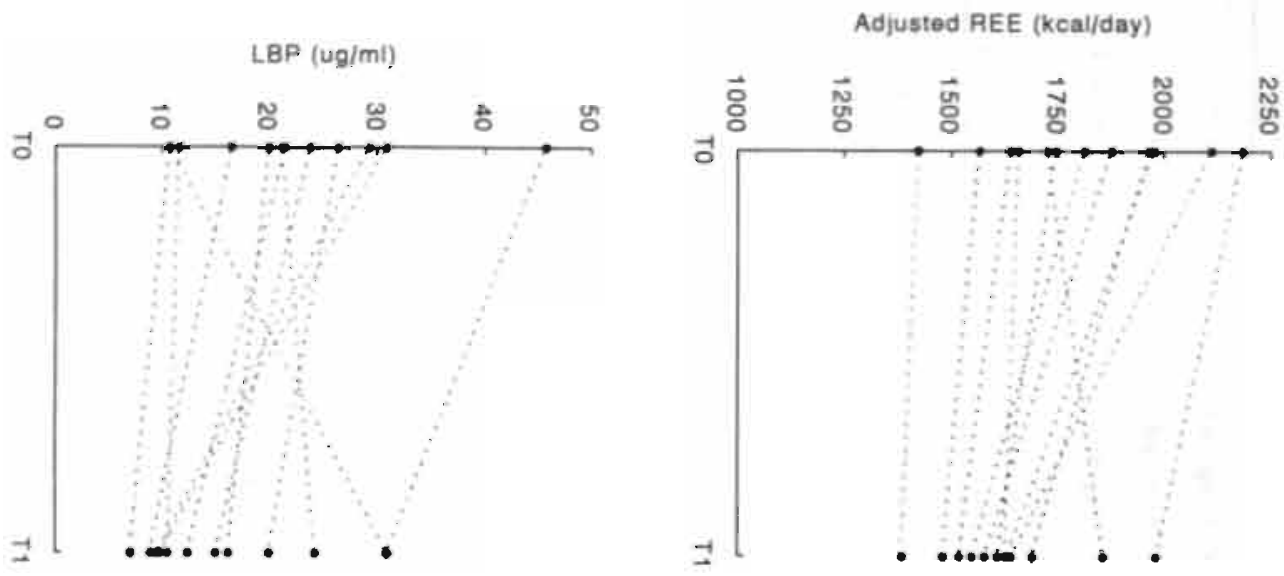

त्र

5 응 
$(78.0 \pm 40.4 \mathrm{ng} / \mathrm{ml}$ versus $76.8 \pm 27.8 \mathrm{ng} / \mathrm{ml})$ did not change significantly after treatment with chemotherapy. Both sTNF-receptors and sICAM-I levels were enhanced compared to healthy controls as described in a previous study (5). No correlation could be demonstrated between the decrease in REE or adjusted REE and the decrease of the acute phase proteins. The individual values for REE, adjusted REE, CRP and LBP from all patients are shown in Figure 1.

\section{Discussion}

The present study describes the metabolic and inflammatory characteristics of 12 patients with newly detected SCLC before and after treatment with chemotherapy. A significant reduction in REE, both expressed in absolute terms and adjusted for FFM, was found, while body weight and body composition remained stable. Both acute phase proteins CRP and LBP reduced significantly after treatment with chemotherapy, while both STNF-receptors and sICAM-1 remained elevated. No correlation, however, existed between the decrease in REE or adjusted REE and the decrease of the acute phase proteins.

Hypermetabolism frequently occurs in lung cancer as has been described before both in NSCLC and in SCLC (1-4). Body composition is the most important determinant of REE (30). After treatment with chemotherapy, no significant changes in FFM and FM occurred in SCLC patients in the present study. The observed decrease in REE could therefore not be attributed to changes in body composition. The decrease in REE was not related to a decrease in energy intake. The extent of the correction of the energy balance expressed in $\mathrm{kcal} /$ day suggests that the follow-up period is possibly too short to observe changes in body composition. The short survival time in SCLC also limits the possible duration of a folow-up period $(34,35)$. The findings of stable energy intake during treatment with chemotherapy in SCLC confirm previously reported data (36). The improved treatment of nausea, vomiting and pain, all known to diminish appetite and food intake, could be related to this stabilization of energy intake.

Tumor stage, tumor size, pulmonary function and smoking behavior do not influence the metabolic parameters in lung cancer patients as has been demonstrated before $(1,5,37)$. The absence of significant differences in the decrease of REE and the decrease of adjusted REE between the patients with complete and partial remission is in line with this non-determining role of tumor size on energy metabolism. No significant changes in pulmonary function and smoking behavior could be detected before and after chemotherapeutic treatment (data not shown).

Based on the relationship between metabolic derangements and the inflammatory response in several groups of cancer patients (5-7), changes in levels of inflammatory mediators were considered in order to explain the decrease in resting 


\section{Chapter 9}

energy expenditure. In the present study, a significant reduction in the levels of both acute phase proteins CRP and LBP was found after treatment with chemotherapy, while the levels of both sTNF-receptors and sICAM-1 remained elevated. These data are the first reported changes of inflammatory state after chemotherapy in SCLC. The drop in acute phase response could implicate a decrease of the hepatic metabolic rate. The liver forms part of the FFM and is considered as a high energyrequiring organ just like the skeletal muscles and brain (38). The oxygen consumption of the human liver is estimated to amount to $\pm 65 \mathrm{ml} / \mathrm{min}$ and covers $25 \%$ of total REE in healthy persons, while skeletal muscles and brain cover $25 \%$ and $20 \%$ respectively of total REE (38). Although an increased oxygen consumption in hepatocytes is described in sarcoma bearing rats compared to pair fed controls, no experimental data are at present available on hepatic metabolism in relation to tumor management (39). Further studies on compartmentalization of changes in metabolic rate in metabolically active tissues are necessary to fully understand a possible contribution of the liver or other tissues to these metabolic derangements.

While the levels of acute phase proteins reduced significantly after treatment with chemotherapy, levels of both sTNF-receptors remained elevated. Enhanced levels of both sTNF-receptors have been described in patients with various types of cancer $(7,40-42)$. However, the effects of treatment on levels of both sTNF-receptors in cancer patients have not yet been reported. An impaired renal clearance could not be attributed to the persistence of enhanced levels of both sTNF-receptors $(31,32)$. No disturbed renal function was detected in any of the patients and in addition, plasma creatinine was considered as a covariable in the analysis of covariance for both sTNF-receptors. Another explanation for the enhanced levels could be that both TNF-receptors are shed by SCLC cells after cell death. Enhanced expression of both TNF-receptors has been demonstrated on carcinoma cells of different origins $(43,44)$. There is evidence that tumor cells have a greater tendency than nonmalignant cells to produce and shed soluble forms of their cell surface proteins (45). On the other hand, cell death could induce systemic inflammation resulting in enhanced levels of both sTNF-receptors. Furthermore, at least in patients with partial remission and possibly in patients with complete remission, tumor cells could still be present.

Besides levels of both soluble. TNF-receptors, the soluble isoform of ICAM-I was measured as well. ICAM- 1 is a member of the immunoglubulin supergene family and plays an important role in inflammatory and immune responses (46). The possible role of circulating adhesion molecules is not yet fully elucidated. By competing with the membrane-bound receptors for their ligands, the release of adhesion molecules may induce a decrease in the potential adhesiveness of leucocytes (47). Otherwise, soluble adhesion molecules can act as costimulatory factors: SICAM-1 has been demonstrated to deliver chemokinetic signals to lymphocytes and to enhance cytotoxic production and T-cell proliferative responses stimulated by alloantigen in mixed lymphocyte cultures (48). Based on the 
correlation between high sICAM-1 levels and reduced survival rates in patients with malignant melanoma (49), it has also been suggested that sICAM-1 may represent an escape mechanism of tumors from the cytotoxicity mediated by immuno-effector cells (50). Noticeable, in cultured renal tumor cells, an inverse relationship was found between expression and release of ICAM-1 by Santarosa et al (51). In the same study, enhanced levels of sICAM-1 were demonstrated in renal cancer patients with metastatic disease compared to tumor free patients 4 weeks after nephrectomy. However, half of the tumor free patients had still enhanced levels of sICAM-1 (51). Our data confirm the persistence of enhanced sICAM-1 levels despite chemotherapeutic intervention in SCLC patients. Increased sICAM-1 levels have been reported to correlate with disease activity (52) in a wide range of organ specific diseases and circulating levels of SICAM-1 were indicators of disease progression of various malignant tumors (53-56). The role of the soluble adhesion molecules needs to be elucidated in further human studies.

In conclusion, chemotherapeutic treatment attenueates the tumor related metabolic derangements and acute phase response. 


\section{Chapter 9}

\section{References}

1. Staal-van den Brekel AJ, Schols AMWJ, ten Velde GPM, Buurman WA, Wouters EFM. Analysis of the energy balance in lung cancer patients. Cancer Res 1994; 54:6430-6433

2. Hansell DT, Davies JWL, Burns HJG. The effects on resting energy expenditure of different tumor types. Cancer 1986; 58:1739-1744

3. Fredrix EWHM, Wouters EFM, Soeters PB, van der Aalst CJM, Kester ADM, von Meyenfeldt MF et al. Resting energy expenditure in patients with non-small cell lung cancer. Cancer 1991; 68:1616-1621

4. Russell DMcR, Shike M, Marliss EB, Detsky AS, Shepherd FA Feld R et al. Effects of total parenteral nutrition and chemotherapy on the metabolic derangements in small cell lung cancer. Cancer Res 1984; 44:1706-1711

5. Staal-van den Brekel AJ. Dentener MA, Schols AMWJ, Buurman WA, Wouters EFM. Increased resting energy expenditure and weight loss are related to a systemic inflammatory response in lung cancer patients. J Clin Oncology 1995; 13: 2600-2605

6. Falconer SJ, Fearon KCH, Plester CE, Ross JA, Carter DC. Cytokines, the acute phase response and Resting Energy Expenditure in cachectic patients with pancreatic cancer. Ann Surgery $1994 ; 219: 325-331$

7. Denz H, Orth B, Weiss G, Gallati H, Herrmann R, Huber P, Wachter H, Fuchs D. Serum soluble tumour necrosis factor receptor 55 is increased in patients with haematological neoplasia and is associated with immune activation and weight loss. Eur J Cancer 1993; 29a: 2232-2235

8. Fong Y, Moldawer, Marano M, et al: Cachectin/TNF or IL- $1 \alpha$ induces cachexia with redistibution of body proteins. Am J Physiol 1989; 25:R659-R665

9 Robbins SL, Cotran RS, Kumar VK. Pathologic basis of disease 1984, ed. 3, Edited by Saunders WB. Philadelphia 1984: 749-757

10. Carney DN. Biology of small-cell lung cancer. The Lancet 1992; 339:843-846

11. Staal-van den Brekel AJ. Schols A, Buurman W, Wouters E. Hypermetabolism is more pronounced in patients with small cell lung carcinoma (SCLC) compared to patients with nonsmail cell lung carcinoma (NSCLC) and healthy controls. Eur Resp J 1995; 8:232s

12. Jebb SA, Osborne RJ. Dixon AK. Bleehen NM, Elia M. Measurement of resting energy expenditure and body composition before and after treatment of small cell lung cancer. Ann Oncology 1994: 5:915-919

13. Mountain CF. A new international staging system for lung cancer. Chest $1986 ; 89: 225 \mathrm{~s}-233 \mathrm{~s}$

14. Patel AM, Dunn WF. Trastek VF. Staging systems of lung cancer. Mayo Clin Proc 1993; $68: 475-482$

15. Fredrix EWHM, Soeters PB, Von Meyenfeldt MF, Saris WHM. Measurement of resting energy expenditure in a clinical setting. Clin Nutrition 1990; 9:299-304

16. Lukaski HC, Johnson PE, Bolonchuk WW, Lykken GI. Assessment of fat-free mass using bioelectrical impedance measurements of the human body. Am J Clin Nutr 1985; 41:810-817

17. Deurenberg P. Weststrate JA. Paymans I, van der Kooy K. Factors affecting bioelectrical impedance measurements in humans. Eur J Clin Nutrition 1988; 42:1017-1022

18. Schols AMWJ. Dingemans ANC. Soeters PB, Wouters EFM. Within day variation of bioelectrical resistance measurements in patients with chronic obstructive pulmonary disease. Clin Nutrition 1990: 9:266-271

19. Chumlea. WC, Baumgartner RN. Status of anthropometry and body composition data in elderly subjects. Am J Clin Nutrition 1989; 50:1158-1166

20. Zarowitz BJ, Pilla AM. Bioelectrical impedance in clinical practice. DICP. The Annals of Pharmacotherapy 1989: 23:548-555

21. Fredrix EWHM, Saris WHM, Soeters PB, Kester ADM, von Meyenfeldt MF, Wouters EFM, 
Westerterp KR. Estimation of body composition by bioelectrical impedance in cancer patients. Eur J Clin Nutrition 1990; 44:749-752

22. Cameron ME, van Staveren WA. Manual on Methodology for Food Consumption Studies, Oxford. United Kingdom: Oxford University Press, 1988

23. NEVO Tabel: Stichting Nederlands Voedingsstoffenbestand. 's Gravenhage, the Netherlands. Voorlichtingsbureau voor de Voeding, 1990

24. Leeuwenberg JFM, Jeunhomme GMMA, Buurman WA. Slow release of soluble TNF-receptors by monocytes in vitro. J Immunology 1994; 152:4036-4043

25. Froon A.HM, Dentener MA, Greve JWM, Ramsay G, Buurman WA. LPS toxicity regulating proteins in bacteremia. I Inf Dis 1995; 171: 1250-1257

26. Leeuwenberg JFM. Smeets EF, Neefjes JJ, et al: E-selectin and intercellular adhesion molecule$I$ are relased by activated human endothelial cells in vitro. Immunology 1992; 77:543-549

27. Collichio FA. Woolf PD, Brower M. Management of patients with small cell carcinoma and the syndrome of ectopic corticotropin secretion. Cancer 1994; 73:1361-1367

28. Shepherd F, Laskey J, Evans W, Goss P, Johansen E, Khamsi F Cushing's syndrome associated with ectopic corticotropin production and small cell lung cancer. J Clin Oncol 1992; 10:21-27

29. Larsen K. Creatinine assay by a reaction-kinetic approach. Clin Chem Acta 1972; 41:209-217

30. Ravussin. E and Bogardus C. Relationship of genetics, age, and physical fitness to daily energy expenditure and fuel utilization. Am J Clin Nutr 1989; 49:968-975

31. Froon AHM, Bemelmans MHA, Greve JW, van der Linden CJ, Buurman WA. Increased plasma concentrations of soluble tumor necrosis factor receptors in sepsis syndrome: correlation with plasma creatinine values. Crit Care Med 1994; 22:803-809

32. Brockhaus M, Bar-Khayim Y, Gurwicz S, Frensdorff A, Haran N. Plasma tumor necrosis factor soluble receptors in chronic renal failure. Kidney Int 1992; 42:663-667

33. SPSS/PC+ Statistics 4.0 for the IBM.PC/XT/AT and PS/2, M.J. Norusis /SPSS Inc, New York 1990

34. Österlind K. Andersen PK. Prognostic factors in small cell lung cancer: multivariate mode! based on 778 patients treated with chemotherapy with or without irradiation Cancer Res. 1986; $46: 4189-4194$

35. O'Connell JP, Kris MG, Gralla RJ, Groshen S, Trust A, Fiore JJ, Kelsen DP, Heelan RT. Golbey RB. Frequency and prognostic importance of pretreatment clinical characteristics in patients with advanced non-small cell lung cancer treated with combination chemotherapy. J Clin Oncol 1986; 4: 1604-1614

36. Ovesen L, Hannibal J, Allingstrup L. Dietary intake in patients with small cell lung cancer: the effect of aggressive chemotherapy. Eur J Clin Nutr 1992; 46:535-537

37. Fredrix EWHM, Soeters PB, Wouters EFM, Deerenberg IM, Meyenfeldt von MF, Saris WHM. Effect of different tumor types on resting energy expenditure. Cancer Res 1991; 51:6138-6141

38. Nelson KM. Weinsier RL, Long CL. Schutz Y. Prediction of resting energy expenditure from fat-free mass and fat mass. Am J Clin Nutr 1992: 56:848-856

39. Roh MS, Ekman LG. Jeevanandam, M. Brennan MF. Elevated energy expenditure in hepatocytes from tumor-bearing rats. J Surg Res $1985 ; 38: 407-415$

40. Aderka D. Engelmann H. Hornik V. Skornick. Y, Levo Y, Wallach D, Kushtai G. Increased serum levels of soluble receptors for tumor necrosis factor in cancer patients. Cancer Res 1991; 51:5602-5607

41. Digel W, Porzsolt F, Schmid M, Herrman F, Lesslauer W. Brockhaus M. High levels of circulating soluble receptors for tumor necrosis factor in hairy cell leukemia and type B chronic lymphocytic leukemia. J Clin Invest 1992; 89:1690-1693

42. Langkopf F. Atzpodien J. Soluble tumour necrosis factor receptors as prognostic factors in cancer patients. The Lancet 1994:344:57-58 


\section{Chapter 9}

43. Biberstein von SE, Spiro JD, Lindquist R, Kreutzer DL. Enhanced tumor cell expression of tumor necrosis factor receptors, in head and neck squamous cell carcinoma. Am J Surg 1995: $170: 416-421$

44. Gatanaga M, Grosen EA, Burger RA, Granger GA, Gatanaga T: Release of soluble TNF/LT receptors from a human ovarian tumor cell line (PA-1) by stimulation with cytokines in vitro. Lymphokine Cytokine Res 1993; 12:249-253

45. Black PH. Shedding from normal and cancer cell surface. N Engl J Med 1980; 303:1415-1416

46. Rothlein, R., Czajkowski, M., O'Neil, N.M., Marlin, S., Mainolfi, E. and Merluzzi, V.R., Induction of intercellular adhesion molecule I on primary and continuous cell lines by proinflammatory cytokines. J Immunol 1988; 141: I665-1669

47. Shingu, M., Hashimoto, M., Ezaki, I. and Nobunaga, M., Effect of cytokine-induced soluble ICAM-I from human synovial cells on synovial cell-lymphocyte adhesion. Clin Exp Immunol 1994: 98:46-51

48 McCabe, S.M., Riddle, L., Nakamura, G.R., Prashad, H., Mehta, A., Berman, P.W. and Jardieu, P., siCAM-I enhances cytokine production stimulated by alloantigen. Cell Immunol 1993: 150:364-375

49. Harning, R., Mainolfi, E., Bystryn, J.C., Henn, M., Merluzzi, V.J. and Rothlein, R., Serum levels of circulating intercellular adhesion molecule $\mathrm{I}$ in human malignant melanoma. Cancer Res 1991; 51:5003-5005

50. Becker, J.C., Dummer, R., Hartmann, A.A., Burg, G. and Schmidt, R.E., Shedding of ICAMI from human melanoma cell lines induced by IFN-gamma and tumor necrosis factor-alpha. Functional consequences on cell-mediated cytotoxicity. J Immunol 199I; [47:4398-440 I

51. Santarosa M, Favaro D, Quaia M, Spada A, Sacco C. Talamini R, Galligioni E. Expression and release of intercellular adhesion molecule-1 in renal-cancer patients. Int J Cancer 1995; 62:271275

52. Tsujisaki M, Imai K, Hirata H, Hanzawa Y, Masuya J, Nakano T, Sugiyama T, Matsui M, Hinoda $\mathrm{Y}$, Yachi A. Detection of circulating intercellular adhesion molecule-1 antigen in malignant diseases. Clin Exp Immunol 1991; 85:3-8

53. Christiansen I, Gidlof C, Wallgren AC, Simonson B. Totterman TH. Serum levels of soluble intercellular adhesion molecule $I$ are increased in chronic lymphocytic leukemia and correlate with clinical stage and prognostic markers. Blood 1994; 84:3010-3016

54. Gruss HJ, Dölken G, Brach MA, Mertelsmann R, Herrmann F. Serum levels of circulating ICAM- 1 are increased in Hodgkin's Disease. Leukemia 1993: 7:1245-1249

55. Wolff JM. Stephenson RN, Chisholm GD, Habib FK. Levels of circulating Intercellular adhesion molecule- $\|$ in patients with metastatic cancer of the prostate and benign prostatic hyperplasia. Eur $\|$ Cancer 1995; 31A:339-34।

56. Shijubo, N.. Imai, K., Aoki, S., Hirasawa, M., Sugawara, H., Koba, H., Tsujisaki, M.. Sugiyama, T., Hinoda, Y and Yachi, A.. Circulating intercellular adhesion molecule-I (ICAM1) antigen sera of patients with idiopathic pulmonary fibrosis. Clin Exp Immunol 1992; 89: 258262 
Weight loss in relation to disturbances in energy balance in lung cancer patients is the central theme of the present thesis. Indeed, weight loss is a frequently occurring problem even in patients with newly detected primary lung cancer: $30 \%$ of the patients reported a weight loss of $10 \%$ or more from their pre-illness stable weight (Chapter 2).

In general terms, weight loss is considered to be a consequence of energy imbalance, either by an increased energy expenditure or a decreased energy intake or a combination of both. Although, total energy expenditure is the sum of resting energy expenditure (REE), diet induced thermogenesis and activity related energy consumption, most studies have focused on resting energy expenditure measurements. The present studies confirmed that an increase in resting energy expenditure is a frequent finding in newly detected lung cancer patients: $74 \%$ of the population studied had an increased REE at initial diagnosis (Chapter 2). However, weight loss seemed more related to a decrease in the uptake of calories than to changes in REE, expressed in $\mathrm{kcal} /$ day or $\mathrm{kcal} / \mathrm{kg}$ fat free mass (FFM). Possibly, REE measurement poorly reflects total energy expenditure. This is in line with observations in so called hypermetabolic and normometabolic COPD patients in which no differences could be detected in total energy expenditure (1). Until now only limited data on total energy expenditure are reported in a heterogenous group of cancer patients $(2,3)$. Further studies are therefore indicated on total energy expenditure and its contributing components in homogenous groups of cancer patients.

Although previous data have suggested that hypermetabolism may be considered as a result of underestimation of resting energy expenditure in elderly people (4), the data of the present thesis (Chapter 3), confirm that hypermetabolism, adjusted for body composition, was a constant finding in non-small cell and small cell lung cancer patients compared to an age and sex matched control population.

The data presented in this thesis confirm a relationship between hypermetabolism and weight loss on the one hand, and the presence of an inflammatory response on the other hand (Chapter 4). Hypermetabolism was associated with enhanced levels of soluble TNFreceptor 55, sE selectin, and the acute phase proteins CRP and LBP. Weight loss was related to increased levels of both soluble TNF receptors, soluble ICAM-1, IL-6 and both acute phase proteins CRP and LBP. In the absence of a quantitative effect of total active metabolising mass on the increase on REE, qualitative differences in metabolism in different constituent compartments of the metabolising mass in relation to the inflammatory state have to be considered. In that way, the skeletal muscle mass and the liver are important energy comsuming organs and therefore main determinants of REE. Furthermore, the observation of an association between hypermetabolism and hepatic acute phase protein response (Chapter $\mathbf{4}$ ) is in line with data obtained in patients with pancreatic cancer, demonstrating that REE was significantly enhanced in patients with an ongoing acute phase response compared to patients who did not have such a response (5).

IL-6, IL-1B and TNF- $\alpha$ have been implicated as potential mediators of the acute phase response by direct and prostaglandin mediated pathways (6). The evidence for a relationship between hypermetabolism and hepatic acute phase response is further supported by the observation that administration of ibuprofen, a well known cyclo-oxygenase 
inhibitor, significantly reduced both resting energy expenditure and hepatocyte acute phase protein expression in pancreatic cancer patients (7). It is hypothesized that cyclo-oxygenase inhibition may downregulate acute phase protein production via a prostaglandin-mediated pathway, resulting in reduced responsiveness to pro-inflammatory cytokines, or via a direct effect on hepatic acute phase protein production (7). In patients with unresectable pancreatic cancer, the acute phase protein response is demonstrated as a useful prognostic indicator (8). A relationship between resting energy expenditure and the hepatic acute phase response is also in line with the longitudinal data in small cell lung cancer patients before and after chemotherapeutic intervention (Chapter 9). A concomitant decrease in acute phase protein response and in resting energy expenditure was demonstrated after a standard chemotherapeutic regimen. Interestingly, anti-inflammatory treatment by cyclo-oxygenase inhibition not only offered improvement in palliative support to patients with advanced solid cancer, but even prolonged survival (9). In line with these data, it was shown in animal models that cyclo-oxygenase inhibition by indomethacin led to inhibition of tumor growth and protection of the host from deterioration in body composition, particularly lean body mass (10).

Data of energy balance in non-small cell lung cancer patients before and after surgical resection of the tumor illustrate the importance of longitudinal metabolic and body composition follow-up (Chapter 8). In that way, a special group is formed by non-small cell lung cancer patients treated by radiotherapy but not studied in the present thesis. Bronchoalveolar lavage data after radiotherapy have manifested an enhanced inflammatory state in the alveolar compartment in non-small cell lung cancer patients (11). It has to be considered that persistence of a chronic inflammatory response can result in a marked deterioration in lean body mass in this subgroup of lung cancer patients.

Based on the reported immunohistochemical data (Chapter $\mathbf{4}$ and 5) one can suggest the involvement of a complex tumor-host response in the observed metabolic derangements. Especially, the selectivity of expression of TNF receptors in tumor cells needs further. elucidation not only in relation to metabolism but especially in relation to tumor growth. In that sense, it is interesting to mention data in poxviruses proposing an anti-inflammatory function of cytokine receptors (12). Poxviruses encode homologues of the extracellular binding domain of cellular cytokine receptors "lacking the transmembrane and cytoplasmic domains of their cellular counterpart. It is generally supported that poxviruses, by acquisition of soluble cytokine receptors, block the activity of specific cytokines of the host and function as an anti-inflammatory reagent. We hypothesize that high expression of sTNF receptors by tumor cells could also function as anti-inflammatory reagents and in that way protect the tumor for host related defence processes.

Not only inflammatory mediators have been demonstrated to be responsible for weight loss in cancer, but also other factors have been isolated recently. Leptin, a $16 \mathrm{kDa}$ plasma protein, has been shown to be involved in the regulation of fat metabolism in mice. Recombinant leptin reduces food intake and increases energy expenditure in wild-type mice and its absence in obese mice leads to a massive increase in body fat (13-15). Recently, also a proteoglycan was isolated from mice bearing the MAC16 tumor $(16,17)$. This proteoglycan produced cachexia in vivo by inducing catabolism of skeletal muscle, as measured by tyrosine release. This effect. occurred without a reduction in food and water intake, which is usually found in animals bearing the MACl6 rumor (18). This factor was also present in the urine of cachectic cancer patients, but was absent from normal subjects. patients with weight loss due to trauma, and cancer patients with little or no weight loss. 
The relation between disturbances in metabolism, enhanced inflammatory response and presence of leptins or other cachectic factors in the pathogenesis of the cachectic syndrome needs further investigations.

In conclusion, metabolic assessment has to become an essential component in the integrated approach of the oncological patient. However, the complex etiology of metabolic derangements needs further investigations as well as intervention strategies for metabolic disturbances associated with acute phase protein response in the therapeutic management of cancer patients. 


\section{References}

1. Baarends EM, Schols AMWJ, Pannemans DLE, Westerterp KR, Wouters EFM. Total daily energy expenditure in clinically stable patients with severe COPD and age-matched healthy subjects using the doubly-labeled water method. Am J Resp Crit Care Med 1995; 151:A206

2. Warnold I, Lundholm K, Schersten T. Energy balance and body composition in cancer patients. Cancer Res 1978; 38:1801-1807

3. Edström S, Bennegard K. Edén E, Lundholm K. Energy and tissue metabolism in patients with cancer during nutritional support. Arch ottolaryngol 1982; 108:697-699

4. Fredrix EWHM, Soeters PB, Deerenberg IM, Kester ADM, von Meyenfeldt MF, Saris WHM. Resting and sleeping energy expenditure in the elderly. Eur J Clin Nutr 1990; 44:741-747

5. Falconer SJ, Fearon KCH, Plester CE, Ross JA, Carter DC. Cytokines, the acute phase response and resting energy expenditure in cachectic patients. with pancreatic cancer. Ann Surg 1994; 219:325-331

6. Heinrich PC. Castell JV. Andus T. Biochem J 1990; 265:621-626

7. Wigmore SJ, Falconer JS, Plester CE, Ross JA, Maingay JP, Carter DC, Feraon KCH. Ibuprofen reduces energy expenditure and acute-phase protein production compared with placebo in pancreatic cancer patients. Brit J Cancer 1995; 72:185-188

8. Falconer JS, Fearon KCH, Ross JA, Elton R, Wigmore SJ. Garden OJ, Carter DC. Acute-phase protein response and survival duration of patients with pancreatic cancer. Cancer 1995; 75:2077. 2082

9. Lundholm K, Gelin J, Hyltander A, Lönnroth C, Sandström, Svaninger. Anti-inflammatory treatment may prolong survival in undernourished patients, with metastatic solid tumors. Cancer Res 1994; 54: 5602-5606.

10. Gelin J. Andersson C. Lundholm K. Effects of indomethacin, cytokines, and cyclosporin A on tumor growth and the subsequent development of cancer cachexia. Cancer Res 1991; 51: 880885

11. Maasilta P, Hallman M, Taskinen E, Kivisaari L, Mattson K. Bronchoalveolar lavage fluid findings following radiotherapy for non-small cell lung cancer. Int J Radiation Oncology Biol Phys 1993; 26:117-123

12. Alcami A. Smith GL. Cytokine receptors encoded by poxviruses: a lesson in cytokine biology. Immunol Today 1995; 16:474-478

13. Halass JL, Gajiwala KS, Maffei M, Cohen SL, Chait BT, Rabinowitz D, Lallone RL, Burley SK. Friedman JM. Weight-reducing effects of the plasma protein encoded by the obese gene. Science 1995: 269: 543-546

14. Campfield LA, Smith FJ, Guisez Y, Devos R, Burn P. Recombinant mouse ob protein: evidence for a peripheral signal linking adiposity and central neural networks. Science 1995; 269:546-549

15. Pelleymounter MA, Cullen MJ, Baker MB, Hecht R, Winters D, Boone T, Collins F. Effects of the obese gene product on body weight regulation in ob/ob mice. Science 1995; 269:540-543

16. Todorov P, Cariuk P, McDevitt T, Coles B, Feraon K, Tisdale M. Characterization of a cancer cachectic factor. Nature 1996; 379: 739-742

17. Todorov PT, McDevitt TM, Cariuk P, Coles B, Deacon M, Tisdale MJ. Induction of muscle protein degradation and weight loss by a tumor product. Cancer Res 1996; 56: 1256-1261

18. Beck SA. Tisdale MJ. Production of lipolytic and proteolytic factors by a murine tumorproducing cachexia in the host. Cancer Res 1987; 47:5919-5923 


\section{Summary}

The present thesis describes the metabolic disturbances in lung cancer patients. Weight loss is a frequently occurring problem in patients with lung cancer and is an early sign of disease. Different studies have shown that weight-stable patients have a better prognosis and a better response to treatment than weight-losing patients. In Chapter 2 the energy balance between resting energy expenditure (REE) and energy intake was assessed and the contributing factors to the elevated REE were analyzed in 100 newly detected lung cancer patients. A substantial number of patients $(30 \%)$ had a weight loss of $10 \%$ or more from their pre-illness stable weight. An elevated REE was even found in $74 \%$ of the patients. Stratification by tumor localization revealed that patients with a central tumor had a significantly higher REE and higher level of C-reactive protein (CRP) compared to patients with a peripheral tumor. Dietary intake was significantly lower in the weight-losing group compared to the weight stable group. Tumor localization and inflammation were found to be contributing factors to the elevated REE as demonstrated by multiple regression analysis.

Lung cancer can be subdivided into two groups according to histology: small cell lung carcinoma ( SCLC) and non-small cell lung carcinoma (NSCLC). Since both groups have different characteristics, we hypothesized that the influence on energy metabolism and inflammatory mediators might be different. REE was measured in 66 patients with lung cancer - 33 SCLC and 33 NSCLC patients- and in 33 healthy controls, matched for age, sex and fat free mass (FFM) (Chapter 3). An increased REE adjusted for FFM was found in the lung cancer population compared to controls. Subdivision of the lung cancer population according to histology revealed that patients with SCLC had an increased REE adjusted for FFM compared to patients with NSCLC. FFM explained the greatest part of the elevation in REE in controls and NSCLC respectively, but in SCLC FM was a significant determinant of the variation in REE as well. Increased jevels of cortisol were found in the SCLC population compared to the NSCLC population but cortisol levels remained within the normal range. Moreover, sTNF-R75 levels were increased in SCLC compared to NSCLC.

Based on experimental studies, it has been suggested that inflammatory mediators are involved in the metabolic derangements in cancer patients. Key roles have been attributed to the inflammatory cytokines TNF- $\alpha$, Interleukin (IL)-1 and IL-6. Therefore the presence of inflammatory mediators in plasma was analyzed and related to the presence of the increased REE and weight loss in patients with NSCLC in Chapter 4. Biologically active TNF- $\alpha$ is difficult to detect because of its short half-time that makes detection dependent on frequency of sampling. Therefore both soluble TNF-receptors 55 (sTNF-R55) and sTNF-R75 were determined as well. In addition the soluble adhesion molecules Intercellular Adhesion Molecule 
(ICAM)-1 and E-selectin, and the acute phase proteins lipopolysaccharide (LPS)binding protein (LBP) and CRP were determined in plasma of 87 NSCLC patients. Enhanced levels of both sTNF-receptors, sICAM-1 and the acute phase proteins CRP and LBP were detected in NSCLC patients compared to healthy controls. In addition, inflammatory mediators were compared between hypermetabolic (REE/Harris Benedict (HB) equation $2110 \%$ ) versus normometabolic (REE/HB < $110 \%$ ) patients and between patients who lost weight (more than $10 \%$ loss of preillness weight) versus those whose weight remained stable. Hypermetabolic patients were found to have significantly increased levels of sTNF-R55, sE-selectin, LBP and CRP compared with normometabolic patients. Weight loss was related with increased levels of both sTNF-receptors, sICAM-1, IL-6, LBP and CRP. No correlation could be demonstrated between hypermetabolism and the inflammatory mediators.

In order to investigate whether the tumor itself was the origin of the increased levels of cytokines or whether the systemic inflammatory response of the patients was enhanced in response to the presence of the tumor, immunohistochemical studies were performed with antibodies against different inflammatory mediators. Both Chapter 5 and Chapter $\mathbf{6}$ describe the results of these studies. Tissues were collected from resection specimens of patients undergoing thoracotomy for NSCLC. Both paraffin and cryostat sections were investigated. In general, CD68 reactive monocytes were present in tumor stroma as well as lymphocytes, consisting mainly of T-lymphocytes. Lymphoid aggregates were present to a variable extent at the edge of the NSCLC fields or in between the outer fields of carcinoma cells. The aggregates consisted mainly of B-lymphocytes with scattered T-lymphocytes. TNFreceptor expression could be demonstrated on NSCLC cells but not on normal bronchial epithelium. The pro-inflammatory cytokines TNF- $\alpha$, IL- 6 and IL- 8 were expressed by NSCLC cells as well as by monocytes in tumor stroma. However, the staining patterns observed indicated an activated status of only a minority of the inflammatory cells in tumor stroma. Furthermore the expression of adhesion molecules was investigated in the lung cancer specimens. The staining patterns observed on endothelial cells indicated an active status of NSCLC vessels. The phenotypic pattern of the vessels looked similar to the vascular component of inflammation. ICAM-1 and vascular cell adhesion molecule (VCAM)-1 were present on NSCLC cells and suggested a functional role in the process of chemotaxis for iumor cells as well.

Further the local inflammatory response in the alveolar compartment was assessed in NSCLC patients (Chapter 7). To this end, inflammatory mediators in bronchoalveolar lavage fluid (BALF) and cytokines produced by alveolar macrophages (AM) were investigated. Twenty patients with newly detected NSCLC and 9 control subjects were studied. BAL was performed in the affected lung as well as in the contralateral lung of NSCLC patients and only unilaterally in control subjects. Comparable results were demonstrated for the levels of the inflammatory mediators TNF- $\alpha$, Interleukin (IL)-6, IL-8, both soluble TNF-receptors and the soluble 
adhesion molecules E-selectin and Intercellular Adhesion Molecule (ICAM)-1 between the affected lung and the contralateral lung in the NSCLC population as well as between the NSCLC population and the control subjects. Moreover, no significant differences in cytokine profiles of AM were detected between AM obtained from the affected lung and from the contralateral lung, respectively. These data suggest that the enhanced inflammatory state, as demonstrated in plasma and in the interstitial compartment around the tumor cells in NSCLC, was not reflected in the alveolar compartment in NSCLC.

Most of the studies on energy metabolism in cancer patients are based on crosssectional studies. Only limited data are available about the effects of treatment on energy metabolism. Therefore the influence of surgical removal of the tumor on energy balance, body weight and body composition was investigated in NSCLC patients in Chapter 8. Patients with curative tumor resection showed an increase in body weight over an one year period, in contrast to patients with tumor recurrence who lost weight. The weight gain consisted predominantly of fat mass, while the weight loss consisted for more than half of FFM. Body weight was increased in hypermetabolic as well as in normometabolic patients one year after successful removal of the tumor. However, while El/REE was significantly increased in hypermetabolic patients, it was not changed in normometabolic patients. These results suggest that hypermetabolic NSCLC patients undergoing curative resection show an improvement in energy balance caused by both a decreased REE and an increased EI. This positive energy balance results in weight gain, which consists predominantly of FM.

The last study (Chapter 9) described energy metabolism and systemic levels of inflammatory mediators in SCLC patients before and after treatment with chemotherapy. A significant reduction in REE was found irrespective of therapeutic outcome while body weight and body composition remained stable. The levels of acute phase proteins CRP and LBP reduced significantly after treatment with chemotherapy, while the levels of both sTNF-receptors and sICAM-1 remained enhanced. No correlation, however, existed between the decrease in REE and the decrease of the acute phase proteins. 


\section{Samenvatting}

Het huidige proefschrift beschrijft de metabole veranderingen in patiënten met longkanker. Gewichtsverlies is een veel voorkomend probleem bij patiënten met longkanker en is een van de eerste tekenen van ziekte. In verschillende studies is aangetoond dat patiënten met een stabiel gewicht een betere prognose en een betere reactie op therapie hebben dan patiënten met gewichtsverlies. De energiebalans tussen de ruststofwisseling en de energie inname is bepaald in hoofdstuk $\mathbf{2}$ en de bijdragende factoren voor de verhoging van de ruststofwisseling zijn geanalyseerd in 100 patiënten waarbij recent longkanker is vastgesteld. Een aanzienlijk aantal patiënten $(30 \%)$ had een gewichtsverlies van $10 \%$ of meer ten opzichte van het gewicht voor ze ziek werden. Een verhoogde ruststofwisseling kwam zelfs voor bij $74 \%$ van de patiënten. Stratificatie door middel van tumor lokalisatie gaf weer dat patiënten met een centrale tumor lokalisatie een significant verhoogde ruststofwisseling en verhoogde concentratie $\mathrm{C}$-reactief eiwit (CRP) hadden vergeleken met patiënten met een perifere tumor lokalisatie. De energie inname was significant lager in de groep met gewichtsverlies vergeleken met de groep die een stabiel gewichts hadden. Tumor lokalisatie en ontsteking bleken bevorderende factoren te zijn voor de verhoogde ruststofwisseling zoals werd vastgesteld door middel van multiple regressie analyse.

Longkanker kan worden onderverdeeld in twee groepen volgens histologie: kleincellig bronchus carcinoom (SCLC) en niet-kleincellig bronchus carcinoom (NSCLC). Aangezien beide groepen verschillende kenmerken hebben, vormden wij de hypothese dat de invloed op energie metabolisme en ontstekingsmediatoren verschillend zou zijn. De ruststofwisseling werd gemeten in 66 patiënten met lonkanker ( 33 SCLC en 33 NSCLC patiënten) en in 33 gezonde controle personen, gematched voor leeftijd, geslacht en vetvrije massa (Hoofdstuk 3). Er werd een verhoogde ruststofwisseling aangepast voor de vetvrije massa gevonden in de longkanker groep vergeleken met de groep van controles. Onderverdeling van de longkanker groep naar aanleiding van histologie gaf weer dat patiënten met SCLC een verhoogde ruststofwisseling aangepast voor vetvrije massa hadden vergeleken met de patiënten met NSCLC. De vetvrije massa voorspelde het grootste deel van de verhoging van de rusistofwisseling in de controles en in NSCLC respectievelijk, maar in SCLC was de vetmassa eveneens een significante determinant van de variatie in ruststofwisseling. Verhoogde cortisol concentraties werden aangetoond in de groep met SCLC vergeleken met de groep met NSCLC maar de cortisol concentraties bleven binnen de normale waarden. Bovendien waren de oplosbare TNF-receptor-75 concentraties toegenomen in SCLC vergeleken met NSCLC.

Het is gesuggereerd op basis van dierexperimenten dat ontstekings mediatoren betrokken zijn in de metabole verstoringen in patiënten met kanker. Daarvoor zijn sleutelposities toegekend aan de inflammatoire cytokinen TNF- $\alpha$, Interleukine (IL)-1 
en IL-6. De aanwezigheid van ontstekingsmediatoren in plasma werd vervolgens geanalyseerd en gerelateerd aan de aanwezigheid van een verhoogde ruststofwisseling en gewichtsverlies in patiënten met NSCLC in hoofdstuk 4. Biologisch actief TNF- $\alpha$ is moeilijk te meten in verband met de korte halfwaarde tijd die het aantonen van TNF- $\alpha$ afhankelijk maakt van de frequentie van metingen. Daarom werden eveneens de oplosbare TNF-receptor 55 en TNF-receptor 75 bepaald. Bovendien werden de oplosbare adhesie moleculen Intercellulair Adhesie Molecuul (ICAM)-1 en E-selectin en de beide acute fase eiwitten lipopolysaccharide (LPS)- bindend eiwit (LBP) en CRP bepaald. Er werden verhoogde concentraties van de beide oplosbare TNF-receptoren, oplosbaar ICAM-1 en de acute fase eiwitten CRP en LBP gemeten in patiënten met NSCLC vergeleken met gezonde controles. Tevens werden de concentraties van ontstekingsmediatoren vergeleken tussen de patiënten die hypermetabool waren (REE/Harris Benedict (HB) vergelijking $>110 \%$ ) t.o.v. normometabole patiënten ( $\mathrm{REE} / \mathrm{HB}<110 \%$ ) en tussen patiënten die gewicht verloren (meer dan 10\% van hun oorspronkelijke gewicht) t.o.v. patiënten die stabiel bleven in hun gewicht. Hypermetabole patiënten bleken significant verhoogde concentraties te hebben van de oplosbare TNF-receptor 55, oplosbaar E-selectin, LBP en CRP vergeleken met normometabole patiënten. Gewichtsverlies was gerelateerd aan toegenomen concentraties van de beide oplosbare TNF-receptoren, oplosbaar ICAM-1, IL-6, LBP en CRP. Er werd geen correlatie aangetoond tussen de aanwezigheid van hypermetabolisme en de ontstekingsmediatoren.

Vervolgens werden er immunohistochemische studies verricht met antilichamen tegen de verschillende ontstekingsmediatoren om te onderzoeken of de tumor zelf de bron was van de verhoogde concentraties van cytokinen of dat de systemische ontstekings reactie van de patiënten was toegenomen als reactie op de aanwezigheid van de tumor. Zowel hoofdstuk 5 als hoofdstuk 6 beschrijven de resultaten van deze studies. De weefsels werden verzameld uit operatie materiaal van patiënten met NSCLC die een operatie ondergingen. Zowel paraffine als vriescoupes werden onderzocht. CD68 positieve monocyten en lymfocyten, voornamelijk bestaand uit Tlymfocyten, waren in het algemeen aanwezig in het stroma van de tumor. De lymfocyten aggregaten waren aanwezig in verschillende aantallen aan de grenzen van de NSCLC velden of tussen de buitenste velden van de tumor cellen in gelegen. De aggregaten bestonden voornamelijk uit B-lymfocyten met enkele T-iymfocyten er tussen in gelegen. De expressie van TNF-receptoren kon worden aangetoond op de NSCLC cellen, maar niet op normaal bronchusepitheel. De cytokinen TNF- $\alpha$, IL-6 en IL-8 werden geëxprimeerd door de NSCLC cellen maar ook door de monocyten in het tumor stroma. Echter, de geobserveerde kleuringspatronen toonden alleen een geactiveerde status aan van slechts een klein aantal onstekingscellen in het tumor stroma. Vervolgens werd ook de expressie van adhesiemoleculen onderzocht in de longkanker preparaten. De aankleuringspatronen die werden gezien op de endotheelcellen weerspiegelden een actieve status van de vaten in NSCLC. Het fenotypische patroon van de vaten vertoonde gelijkenissen met de vascularisatie 
zoals die wordt gezien in ontsteking. ICAM-1 en het vasculaire cel adhesie molecuul (VCAM)-1 waren aanwezig op NSCLC cellen en dit kan wijzen op een functionele rol voor de tumor cellen in het ontstekingsproces.

Vervolgens werd de ontstekings reactie in het alveolaire compartiment bepaald in patiënten met NSCLC (hoofdstuk 7). Daarvoor werden de ontstekingsmediatoren in de bronchoalveolaire vloeistof bepaald en werden de cytokinen, die geproduceerd worden door de alveolaire makrofagen, gemeten. Twintig patiënten met recent ontdekt NSCLC en 9 controle personen werden onderzocht. De bronchoalveolaire lavage werd verricht in de aangedane long en in de contralaterale long van de patiënten met NSCLC en unilateraal in controle personen. Er werden vergelijkbare resultaten gevonden voor de concentraties TNF- $\alpha$, IL-6, Il-8, de beide oplosbare TNF-receptoren en de oplosbare adhesie moleculen E-selectin en ICAM-1 tussen de aangedane long en de contralaterale long in de NSCLC groep en de controle groep. Bovendien werden er geen significante verschillen aangetoond tussen de cytokinen profielen van de alveolaire makrofagen verkregen uit de aangedane long en uit de contralaterale long respectievelijk. Deze data suggereren dat de verhoogde ontstekings status, zoals die wordt aangetoond in het plasma en in het interstitiële compartiment rond de tumor cellen in NSCLC, niet wordt weergegeven in het alveolaire compariment.

De meeste studies over energie metabolisme in patiënten met kanker zijn gebasseerd op cross-sectionele studies. Er zijn slechts weinig data beschikbaar over de effecten van behandeling op het energie metabolisme. De invloed van chirurgische verwijdering van de tumor op de energie balans, het lichaamsgewicht en de lichaamssamenstelling werd daarom onderzocht in patiënten met NSCLC in hoofdstuk 8. Patiënten met een curatieve resectie van de tumor vertoonden een toename van hun lichaamsgewicht na een jaar, in tegenstelling tot patiënten waarbij er sprake was van een recidief van de tumor, zij verloren gewicht. De gewichtstoename bestond voomamelijk uit vetmassa, terwijl het gewichtsverlies voor meer dan de helft uit vetvrije massa bestond. $\mathrm{Na}$ een jaar was het lichaamsgewicht toegenomen bij zowel hypermetabole als normometabole patiënten die een curatieve resectie van hun tumor hadden ondergaan. Echter terwijl de verhouding energie inname t.o.v. de ruststofwisseling significant was toegenomen in hypermetabole patiënten, was deze onveranderd in normometabole patiënten. Deze resultaten sugegeren dat hypermetabole patiënten die een curatieve resectie ondergaan, een verbetering van hun energie balans vertonen veroorzaakt door zowel een afgenomen ruststofwisseling als een toegenomen energie inname. Deze positieve energie balans resulteert in een gewichtstoename, welke voornamelijk uit vetmassa. bestaat.

De laatste studie (hoofdstuk 9) beschrijft het energie metabolisme en de systemische concentraties van ontstekingsmediatoren in SCLC patiënten voor en na behandeling met chemotherapie. Een significante afname in ruststofwisseling werd aangetoond onafhankelijk van het resultaat van de therapie terwijl het lichaamsgewicht en de lichaamssamenstelling stabiel bleven. De concentraties van de acute fase eiwitten 
CRP en LBP namen significant af na behandeling met chernotherapie, terwijl de concentraties van de beide oplosbare TNF-receptoren en oplosbaar ICAM-1 verhoogd bleven. Er bestond echter geen correlatie tussen de afname in ruststofwisseling en de afname van de acute fase eiwitten. 



\section{Dankwoord}

Regelmatig wordt het schrijven van een proefschrift vergeleken met sportprestaties. Het roeien was vvor mij een favoriete bezigheid voor dat ik begon met het NWOprojekt in Maastricht. Het plezier wat een zogeheten "lopende" boot je verschafte, maakte eindeloze periodes van "niet lopen" van de boot meer dan goed. Het lopen van dit bootje of te wel het uitvoeren van het onderzoek beschreven in dit proefschrift, werd mogelijk gemaakt door de hulp van zeer velen.

Allereerst wil ik de coaches langs de kant bedanken die veel werk hebben verricht om de boot goed te laten lopen. Professor Wouters wil ik hartelijk bedanken voor de begeleiding van dit projekt, zijn heldere inzichten in deze complexe materie en zijn waardevolle ideeën voor het manuscript. Wim Buurman wil ik bedanken voor zijn inzet om mij de wereld van de immunologie te doceren. Onder jouw leiding heb ik veel plezier in het laboratorium werk gekregen.

Er bestaan vele soorten roeiboten, gestuurde en ongestuurde boten, eenpersoons boten of boten met 2, 4 of zelfs 8 mensen. Slechts zelden voer ik in een eenpersoonsboot, het was veel prettiger om dit met een ploeggenoot of ervaren stuurman te doen.

De tweepersoons boot ook wel een dubbel twee genoemd, voer ik vaak met Mieke. Aanvankelijk samen gestart op een projekt, eindigen we nu met twee verdedigingen van proefschriften. Mieke, ik wil je hartelijk bedanken voor de eindeloze bepalingen van onze samples en het gestoei met de bronchoalveolair lavages. Ik wens je veel succes met jouw verdediging. Iedere woensdag werd het bootje gedeeld met Lily. Lily, ik heb veel van je geleerd, je was een waardevolle ploeggenoot en ik keek er elke week naar uit om samen met jou patiënten te onderzoeken.

Naast de ongestuurde nummers, bestaan er ook de gestuurde nummers binnen de roeiwereld. Dat ervaren stuurlui je door heel wat problemen heen kunnen manoevreren, is regelmatig gebleken in mijn onderzoeksperiode.

Annemie, jou wil ik bedanken voor alle uren begeleiding. Jouw kennis van de. statistiek was zeer waardevol voor de vele analyses van de studies waar steeds maar weer andere factoren ook invloed konden hebben op de resultaten. Helaas werd jouw stelling "Onderzoekers die zich bezig houden met COPD patiënten, krijgen dochters en onderzoekers die zich bezig houden met longkanker krijgen zonen" op het laatste moment nog doorknuist door de familie Simons, anders was hij zeker opgenomen bij de stellingen.

Erik Thunnissen wil ik bedanken voor het eindeloze geduld om al die coupes door te nemen en de gezellige uren achter de microscoop, liefst vergezeld van vele koekjes. Door jouw inzet heb ik de coupes van de patholoog met hele andere ogen leren bekijken. Margriet en Anick wil ik bedanken voor hun hulp bij het uitzoeken van de: diverse immunohistochemie technieken.

De boot werd gelukkig ook regelmatig in het water gelegd voor pleziertochtjes. Met 
de andere AIO's van de afdeling longziekten Esther, Erica, Mariëlle en Eva hebben we menig tochtje door de stad Maastricht of congressteden gemaakt. Ik wil jullie bedanken voor alle uitwisseling van ideeën en jullie gezellige belangstelling.

Veel grotere boten waren er nodig om met het lab Heelkunde op stap te gaan. Gaby, Trudy, Maarten, Marc, Jet, Jessica, Monique, Albert, Robert en Berry, vele sprintjes en duurtochten werden er verricht in het lab. Ik wil jullie bedanken voor de vele interessante discussies op de werkvloer en de gezelligheid bij allerlei andere activiteiten die we met z'n allen hebben ondernomen. Zonder jullie had ik nooit die eindstreep gehaald.

Ook de boot gevuld met arts-assistenten was een prettig evenement. Herman-Jan, Jean, Ellen, Frank, Nicolle, Bernard, Monique, Marcel, Harry, Joan, Guus en vele andere AGNIO's hielpen mij met het vinden van patiënten en de gezellige lunches zorgden er voor dat ik weer verder kon met mijn werk, dank jullie wel.

De longartsen Guul ten Velde, Ame van Belle, Geert-Jan Wesseling en Marjolein Drent, jullie wil ik bedanken voor jullie hulp bij de bronchoalveolaire lavages en jullie support tijdens mijn onderzoekstijd.

De patiënten wil ik bedanken voor hun inzet voor het onderzoek in deze zo moeilijke tijd voor hen, hopelijk kunnen de therapeutische mogelijkheden van het nu afgeronde onderzoek in een volgend projekt verder worden onderzocht.

De secretaressen Manon, Gonda, France, Marie-José en Nicole, wil ik bedanken voor hun secretariële ondersteuning en hun werk om alle post maar weer in Eindhoven te krijgen.

Jeanine van A3 wil ik apart bedanken, zonder jouw inzet en coördinatie was het aantal patienten voor dit klinische onderzoek nooit zo groot geworden, reuze dank daarvoor.

De verpleging van afdeling A3 wil ik bedanken voor hun zorg en de voorbereidingen van de patiënten voor de REE-metingen. Het was erg gezellig om even neer te strijken voor een praatje of een drankje op jullie afdeling.

De afdeling dietitiek en $\mathrm{m} . \mathrm{n}$. Marja, wil ik bedanken voor de uitvoering van alle "diet-histories" en in het meedenken om de anamnese zo goed mogelijk uit te diepen in deze specifieke groep patiënten.

De internisten en arts-assistenten van het Diaconessenhuis in Eindhoven wil ik bedanken voor hun hulp en steun in deze drukke tijd en de taken die ze van mij hebben overgenomen.

Als laatste wil ik mijn thuishavens in Maastricht bedanken. Margot en Joep, jullie vertrouwde gezichten uit Utrecht en jullie warme gastvrijheid waren goud waard voor mij in de OIO-jaren in Maastricht. Nicole, jouw gezellige flat en de altijd gevulde theepot waren heerlijk om even de gedachten op nul te zetten. Jesje en Mark, ik mocht altijd even bij jullie bijkornen onder het genot van een heerlijke hap om daarna weer met hernieuwde energie verder te gaan met het werk, dank jullie wel. 
Alle andere vrienden en fannilie leden wil ik bedanken voor hun ondersteuning en belangstelling. Mijn ouders wil ik bedanken voor alle mogelijkheden die zij mij geboden hebben om zo ver te komen.

Als allerlaatste wil ik jou bedanken Flip, voor al je belangstelling, ondersteuning en zorg voor Diederik als ik weer eens achter de computer moest in mijn vrije tijd. Eindelijk hebben we dan weer wat meer tijd voor ontspanning met zijn drieën en gezelligheid met vrienden en familie. 


\section{Curriculum vitae}

Jeske Staal-van den Brekel werd op 18 augustus 1965 geboren te Vught. Zij behaalde het gymnasium $\beta$ diploma in 1983 aan de scholengemeenschap "Maurickcollege" te Vught. In datzelfde jaar begon zij de studie Medicijnen aan de Rijksuniversiteit te Utrecht. In maart 1991 deed zij haar artsexamen waarna zij korte tijd werkte in Engeland als house-officer in Stoke-on-Trent op de chirurgische afdeling. In september 1991 begon zij als onderzoeker in opleiding (OIO) bij de vakgroep pulmonologie (prof E.F.M. Wouters) in het Academisch Ziekenhuis te Maastricht. In nauwe samenwerking met de vakgroep Algemene Heelkunde ( W.A. Buurman) werd gedurende 4 jaar het in dit proefschrift beschreven onderzoek verricht. Het projekt werd gefinancierd door het N.W.O.. Momenteel is zij in Eindhoven bezig met de voor-opleiding Interne Geneeskunde. in het Diaconessenhuis te Eindhoven o.l.v. dr H.R. Haak. 
Analysis of the energy balance in lung cancer patients. AJ Staal-van den Brekel, AMWJ Schols, GPM ten Velde, WA Buurman, EFM Wouters. Cancer Res 1994; 54:6430-6433

Hypermetabolism is more pronounced in small cell lung carcinoma compared to non-small cell lung carcinoma and healthy controls. AJ Staal-van den Brekel, AMWJ Schols, MA Dentener, GPM ten Velde, WA Buurman, EFM Wouters. Thorax, submitted

Increased resting energy expenditure and weight loss are related to a systemic inflammatory response in lung cancer patients. AJ Staal-van den Brekel, MA Dentener, AMWJ Schols, WA Buurman, EFM Wouters. J Clin Oncol 1995; 13: 2600-2605

The expression of cytokines and TNF-receptors in non-small cell lung carcinoma. AJ Staal-van den Brekel, FBJM Thunnissen, WA Buurman, EFM Wouters. J. Pathology, submitted

Expression of E-selectin, Intercellular Adhesion Molecule (ICAM)-1 and Vascular Cell Adhesion Molecule (VCAM)- 1 in non-small cell lung carcinoma. AJ Staal-van den Brekel, FBJM Thunnissen, WA Buurman, EFM Wouters, Virchows Archiv 1996; 428: $21-27$

The enhanced inflammatory response in non small cell lung carcinoma is not reflected in the alveolar compariment. AJ Staal-van den Brekel, MA Dentener, M Drent, GPM ten Velde, WA Buurman, EFM Wouters. Respiratory Medicine, in press

Energy Balance in non-small cell lung cancer patients before and after surgical resection of the tumor. EWHM Fredrix, AJ Staal-van den Brekel, EFM Wouters. Cancer, in press

The effects of treatment with chemotherapy on energy metabolism and inflammatory mediators in smaill cell lung carcinoma. AJ Staal-van den Brekel, AMWJ Schols, MA Dentener, GPM ten Velde, WA Buurman, EFM Wouters. Brit J Cancer submitted

Evidence for a relation between metabolic derangements and increased levels of inflammatory mediators in a subgroup of patients with chronic obstructive pulmonary disease. AMWJ Schols, WA Buurman, AJ Staal-van den Brekel, MA Dentener, EFM Wouters. Thorax 1996; 51: 819-824 



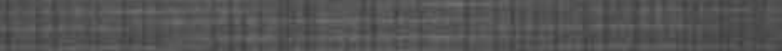
If

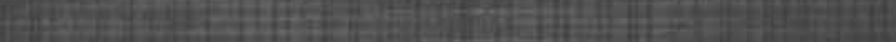

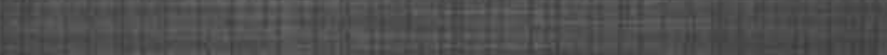
Aftily

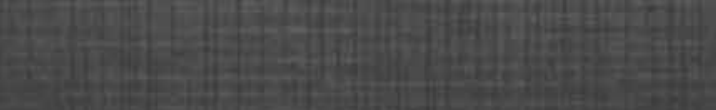

(10) 